Rizzi A. 2018 (ed.), Trust and Proof: Translators in Renaissance Print Culture (Boston and Leiden: Brill), ISBN 9789004323858

\title{
Trust and Proof: Translators in Renaissance Print Culture
}

Acknowledgments $\quad$ x

Foreword

ANTHONY PYM

Introduction

ANDREA RIZZI AND CYNTHIA TROUP

\section{PART I Translators' Rhetorics: Dedication and Imitatio}

\section{BRIAN RICHARDSON}

The Social Transmission of Translations in Renaissance

Italy: Strategies of Dedication

2. ANDREA RIZZI

Monkey Business: Imitatio and Translators' Visibility in

Renaissance Europe

3. MARIE-ALICE BELLE

Rhetorical 'Ethos; and the Translating Self in Early Modern England

\section{PART II Transcultural Translations}

\section{BELÉN BISTUÈ}

Multi-Version Texts and Translators' Anxieties:

Imagined Readers in John Florio's Bilingual Dialogues

\section{Elena CALVILLO}

"No Stranger in Foreign Lands": Francisco de Hollanda and the Translation of Italian Art and Art Theory

\section{AlBReCht ClaASSEN}

Authors, Translators, Printers: Production and Reception of Novels between Manuscript and Print in Fifteenth-Century Germany

\section{DAVID TAVÁREZ}

Reframing Idolatry in Zapotec: Dominican Translations of the Christian Doctrine in Sixteenth-Century Oaxaca 


\section{PART III Women Translating in Renaissance Europe}

8. ROSALIND SMITH

Paratextual economies in Tudor women's translations: Margaret More Roper,

Mary Roper Basset and Mary Tudor

9. BRONWYN REDDAN

Translating Eloquence: History, Fidelity, and Creativity in the Fairy Tales of Marie-Jeanne Lhéritier

10. HILARY BROWN

Female Translators and Print Culture in Sixteenth-Century Germany

Conclusion

DEANNA SHEMEK 


\section{LIST OF CONTRIBUTORS}

MARIE-Alice Belle (Université de Montréal)

Marie-Alice Belle is Associate Professor in Translation Studies at the Université de

Montréal, and Associate Researcher in English at Université Paris 3-Sorbonne

Nouvelle. Her research focuses on translation and book culture in early modern

England, with particular interest in Classical translations and early modern translation

discourse. Publications include Robert Garnier in Elizabethan England: Mary Sidney

Herbert's Antonius (1592) and Thomas Kyd's Cornelia (1594), co-edited with Line

Cottegnies (MHRA Tudor and Stuart Translations, 2017); and the collection

Thresholds of Translation: Paratexts, Print, and Cultural Exchange in Early Modern

Britain (1473-1660), co-edited with Brenda Hosington (Palgrave Macmillan, forthcoming in 2018).

BELÉN BistuÈ (CONICET and Universidad Nacional de Cuyo, Argentina)

Associate Researcher in Comparative Literature for the Argentine Research Council, and Assistant Professor of English at the Universidad Nacional de Cuyo, Belén Bistué specialises in translation history, with a focus on Renaissance collaborative and multilingual translation practices. She currently serves as co-director of the Argentine Comparative Literature Research Project (PAILICO), 2015-2017. Her publications include the monograph Collaborative Translation and Multi-Version Texts in Early Modern Europe (Ashgate, 2013; Routledge, 2016), and the collection Disobedient Practices: Textual Multiplicity in Medieval and Golden Age Spain, co-edited with Anne Roberts (Juan de la Cuesta, 2014).

HILARY BROWN (University of Birmingham)

Hilary Brown is a Lecturer in Translation Studies at the University of Birmingham. She has published widely on the cultural history of translation in Germany. Much of her research has focused on the role of female translators, such as her monograph Luise Gottsched the Translator (Camden House, 2012). Her new monograph project looks at women and translation in Germany $c a$. 1600-1720, and she has just been awarded a Humboldt Fellowship in order to undertake research at the Herzog August Bibliothek, Wolfenbüttel.

\section{ELENA CALVILlo (University of Richmond, USA)}

Elena Calvillo is an Associate Professor of Art History at the University of Richmond (Virginia). Her research has focused on artistic service and imitative strategies in sixteenth-century papal Rome. She has published several essays on the Croatian miniaturist Giulio Clovio at the court of Cardinal Alessandro Farnese, the writings of Clovio's Portuguese contemporary Francisco de Hollanda, and the painter Sebastiano del Piombo. She is now editing a collection of papers on the practice of oil painting on stone supports in sixteenth- and seventeenth-century Europe, Almost Eternal: Painting on Stone and Material Innovation in Early Modern Europe (Brill 2018).

\section{ALBRECHT Classen (University of Arizona)}

Dr. Albrecht Classen is University Distinguished Professor and Director of Undergraduate Studies in the Department of German Studies. He has a broad range of research interests covering the history of medieval and early modern German and European literature and culture from about 800 to 1800 . He has published more than 90 scholarly books, critical editions, translations, and textbooks, and 9 poetry 
volumes of his own (May 2017). At the latest count he has published 630 scholarly articles and 2380 book reviews. He is the recipient of the Bundesverdienstkreuz am Band from the German government (2004).

ANTHONY PyM (University of Melbourne, Australia)

Anthony Pym is Professor of Translation Studies at the University of Melbourne, Distinguished Professor of Translation and Intercultural Studies at Rovira i Virgili University in Tarragona, Spain, and Professor Extraordinary at Stellenbosch University, South Africa. His most recent book is Translation Solutions for Many Languages: Histories of a Flawed Dream (Bloomsbury, 2016).

BRONWYN REDDAN (University of Melbourne, Australia)

Bronwyn Reddan is a Research Fellow with the ARC Centre of Excellence for the History of Emotions at The University of Melbourne. She works on the history of women's writing with a particular focus on the representation of gender and emotion in early modern fairy tales. Her publications include several articles and book chapters examining the gender politics of love and magic in seventeenth-century French fairy tales. She is currently preparing a monograph entitled Love, Power and Gender in French Fairy Tales, 1690-1709.

BRIAN RICHARDSON (University of Leeds, UK)

Emeritus Professor of Italian Language at the University of Leeds and a Fellow of the British Academy, Brian Richardson specialises in the history of the circulation of texts. He was principal investigator, during 2011-2015, on the project Oral Culture, Manuscript and Print in Early Modern Italy, 1450-1700, funded by the European Research Council, and co-edited Interactions between Orality and Writing in Early Modern Italian Culture and Voices and Texts in Early Modern Italian Society (both Routledge, 2016). In 2012 he delivered the Panizzi Lectures at the British Library on Women, Books, and Communities in Renaissance Italy.

ANDREA Rizzi (University of Melbourne, Australia)

Andrea Rizzi is an Australian Research Council Future Fellow (2014-2018) at the University of Melbourne. He has published on vernacular translators in early Renaissance Italy; courtly culture in Ferrara and Mantua; Italian diplomats and translators at the court of Elizabeth I. His most recent work is Vernacular Translators in Quattrocento Italy: Scribal Culture, Authority, and Agency (Brepols 2017). Rizzi has been a Deborah Loeb Brice Fellow (2011) at the Villa I Tatti Harvard University Center for Italian Renaissance Studies, Florence.

DEANNA SHEMEK (University of California, USA)

Deanna Shemek is Professor of Literature at the University of California, Santa Cruz. She wrote Ladies Errant: Wayward Women and Social Order in Early Modern Italy (1998), co-edited Phaethon's Children: The Este Court and its Culture in Early Modern Ferrara (2005) and Writing Relations: American Scholars in Italian Archives (2008). Author of essays on Ariosto, Aretino, Boccaccio, and a number of Renaissance women poets, she is also editor and translator of the Selected Letters of Isabella d'Este (2017). She co-directs an online project for study of the Italian Renaissance, IDEA: Isabella d'Este Archive (http://isabelladeste.web.unc.edu). 
RoSALIND SMITH (University of Newcastle, Australia)

Associate Professor Rosalind Smith specialises in women's poetry, and the relationships between gender, genre, politics, and history in the English Renaissance. She has published widely on early modern women's writing, including Sonnets and the English Woman Writer, 1560-1621 (Palgrave, 2005) and Material Cultures of Early Modern Women's Writing (Palgrave 2104). With Patricia Pender, she coordinates the Early Modern Women's Research Network, and she currently leads an Australian Research Council funded project on early modern women and the poetry of complaint.

\section{DAVID TAVÁREZ (Vassar College)}

David Tavárez, Professor of Anthropology at Vassar College, is the author of The Invisible War: Indigenous Devotions, Discipline, and Dissent in Colonial Mexico (Spanish translation, 2012), editor of Words and Worlds Turned Around: Indigenous Christianities in Colonial Latin America, and co-author of Painted Words: Nahua Catholicism, Politics, and Memory in the Atzaqualco Pictorial Catechism (with Elizabeth Boone and Louise Burkhart), and of Chimalpahin's Conquest (with Susan Schroeder, Anne Cruz, and Cristián Roa). A recent winner of a John Simon Guggenheim Fellowship, he is also the recipient of grants from the NEH, the NSF, EHESS, and the John Carter Brown Library. 


\section{ACKNOWLEDGEMENTS}

This publication originates from years or productive discussions and exchanges between colleagues from Australia, the US, Canada, Argentina, and the UK. Several of the concepts and issues examined in this volume were discussed insightfully at an international conference in Melbourne (August 2015) to which some of the contributors of this volume participated.

A major fellowship from the Australian Research Council Australian (FT140100266) has made this project possible. Further support has also come from the Faculty of Arts at the Universitu of Melbourne.

I am also grateful to Cynthia Troup for her crucial support as both copy-editor and coauthor. Thanks go to Arjan van Dijk and the editor-in-chief of the Library of the Written Word series at Brill, Andrew Pettegree. Your patience and assistance have been extraordinary.

Finally, I would like to thank all contributors to this volume for their support, commitment, and promptness. I have learned much from your work. 
Figure 1: Biblioteca Nacional de España, Res. 214, fol. $1^{\mathrm{r}}$.

Figure 2: London, British Library, Add. 36684, fol. $46^{\mathrm{v}}$

Figure 3: Portrait of Francesco Barozzi in Procli Diadochi Lycii in primum Euclidis elementorum librum commentariorum... (Padua: Grazioso Percaccino, 1560), p. 2

Figure 4: Musée Condé, Chantilly, MS. 721/1672 f.1r. Antoine Macault presents his translation to François I, from Books I, II and III' by Diodorus Siculus (ca.90-ca.20 BCE), ca.1532 (vellum), French School (16th century)

Figure 5: Antoine Macault reading his translation of Diodorus Siculus to King Francis I

Figure 6: London, British Library, Harley 4430, fol. $33^{\mathrm{r}}$ (ca. 1475): Valerius Maximus, translated into French by Simon de Hesdin and Nicolas de Gonesse (ca. 1375-1401)

Figure 7: London, British Library, Royal $14 \mathrm{E} \mathrm{V}$, fol. $5^{\mathrm{r}}$

Figure 8: Printer William Caxton (1415-1492) Presenting His Translation to Margaret of York (1446-1503). Copy of Recuyell Of Historyes Of Troye, Engraving, Huntington Library, San Marino, CA. By permission of De Agostini Picture Library / Bridgeman Images

Figure 9: Colloquia et dictionariolum septem linguarum (Liège, 1589), V4v-V5

Figure 10: Alonso de Molina, Vocabulario en lengua castellana y mexicana (México, 1555)

Figure 11: Rembert Dodoens's Niewe Herball, or Historie of Plantes ([Antwerp], 1578)

Figure 12: Old Testament. Complutensian Polyglot Bible. Berkeley fBS1 1514 Figure 13: Old Testament. London Polyglot Bible. Berkeley f BS1 1655 Figure 14: Florio. His firste Fruites (London, 1578), fols. $8^{\mathrm{v}}-9^{\mathrm{r}}$

Figure 15: Francisco de Hollanda, Belvedere Cleopatra, fol. 8v, Os Desenhos da Antigualhas (c. 1540), Ms. 28-I-20, Biblioteca del Real Monasterio de San Lorenzo El Escorial, (C PATRIMONIO NACIONAL

Figure 16: Francisco de Hollanda, Portrait of Paul III, fol. 1v, Os Desenhos da Antigualhas (c. 1540), Ms. 28-I-20, Biblioteca del Real Monasterio de San Lorenzo El Escorial, (C PATRIMONIO NACIONAL 
Figure 17: Francisco de Hollanda, Portrait of Michelangelo, fol. 2r, Os Desenhos da Antigualhas (c. 1540), Ms. 28-I-20, Biblioteca del Real Monasterio de San Lorenzo El Escorial, (C) PATRIMONIO NACIONAL

Figure 18: Francisco de Hollanda, Muse Melpomene, fol. 10r, Os Desenhos da Antigualhas (c. 1540), Ms. 28-I-20, Biblioteca del Real Monasterio de San Lorenzo El Escorial, (C PATRIMONIO NACIONAL

Figure 19: Francisco de Hollanda, Laocoön, fol. 9v, Os Desenhos da Antigualhas (c. 1540), Ms. 28-I-20, Biblioteca del Real Monasterio de San Lorenzo El Escorial, (C PATRIMONIO NACIONAL

Figure 20: Francisco de Hollanda, Colosseum fol. 5v, Os Desenhos da Antigualhas (c. 1540), Ms. 28-I-20, Biblioteca del Real Monasterio de San Lorenzo El Escorial, (C) PATRIMONIO NACIONAL

Figure 21: Francisco de Hollanda, Pantheon fol. 6r, Os Desenhos da Antigualhas (c. 1540), Ms. 28-I-20, Biblioteca del Real Monasterio de San Lorenzo El Escorial, (C) PATRIMONIO NACIONAL

Figure 22: Francisco de Hollanda, Apollo Belvedere, fol. 9r, Os Desenhos da Antigualhas (c. 1540), Ms. 28-I-20, Biblioteca del Real Monasterio de San Lorenzo El Escorial, (C PATRIMONIO NACIONAL

Figure 23: Francisco de Hollanda, Detail of Figure 8 Apollo Belvedere, fol. 9r, Os Desenhos da Antigualhas (c. 1540), Ms. 28-I-20, Biblioteca del Real Monasterio de San Lorenzo El Escorial, C PATRIMONIO NACIONAL

Figure 24: Francisco de Hollanda, Trophies of Marius, fol. 14v, Os Desenhos da Antigualhas (c. 1540), Ms. 28-I-20, Biblioteca del Real Monasterio de San Lorenzo El Escorial, (C) PATRIMONIO NACIONAL

Figure 25: Francisco de Hollanda, Trophies of Marius, fol. 15r, Os Desenhos da Antigualhas (c. 1540), Ms. 28-I-20, Biblioteca del Real Monasterio de San Lorenzo El Escorial, (C PATRIMONIO NACIONAL

Figure 26: Erasmus, Desiderius, A deuoute treatise vpon the Pater noster, trans. Margaret Roper (London: Thomas Berthelet, $c a$. 1525), fol. A1r. By permission of the British Library, London. 


\section{PREFACE}

\section{Andrea Rizzi and Cynthia Troup}

The 'grand narrative' of pre-print and print in medieval and Renaissance translation has begun to be challenged over the past decade. ${ }^{1}$ As part of his inspiring 'long view' of translation history, Anthony Pym rightly complicates notions of a chronological divide between 'pre-print' and 'print'. With reference to the aforementioned 'grand narrative', Pym points out that at the turn of the print age translation and translators are deemed to have fostered the emergence of source criticism and reconstruction (in Pym's phrase, the text as 'the thing to be trusted'). ${ }^{2}$ The refinement of philology is said to have enhanced confidence and interest in the texts on the part of Renaissance readers. ${ }^{3}$ According to another strand of the 'grand narrative', print technology stimulated the democratisation of knowledge and, inevitably, competition and collaboration between authors, printers, translators, editors, readers, and patrons.

Several aspects of the grand narrative rely on long-held assumptions about periodisation, progressive changes to translative practices, and national and transnational

\footnotetext{
${ }^{1}$ In this volume, the term 'Renaissance' is preferred to 'early modern'. We follow the view that 'Renaissance' indicates broadly "the intellectual, artistic, and cultural movements associated with that term" rather than "social, economic, and political structure and change" of the period 1400-1700. This distinction is however controversial and has been the subject of much discussion. See Jane Tylus and Karen Newman (eds.), Early Modern Cultures of Translation (Philadelphia: University of Pennsylvania Press, 2015), p. 266 n1.

${ }^{2}$ See Foreword in this volume.

${ }^{3}$ Rens Bod, A New History of the Humanities: The Search for Principles and Patterns from Antiquity to the Present (Oxford: Oxford University Press, 2013), pp. 352-353, and José María Fernández and Edward WilsonLee (eds.), Translation and the Book Trade in Early Modern Europe (Cambridge: Cambridge University Press, 2014), p. 13.
} 
paradigms. ${ }^{4}$ Such assumptions have been constructively challenged in recent journal issues and edited volumes concerned with the future of translation history and its methodologies. ${ }^{5}$ Taking heed of these discussions, the present volume embraces agency, identity, and technologies of production as its central focus. 'Agency' here refers to the strategies undertaken by Renaissance translators and printers - and others involved in the book market for translations - to position themselves and their work. ${ }^{6}$ Those involved in the production of translations tended to articulate their role, identity, and the work produced through the use of varied textual practices and other rhetorical means that were conditioned by social rules and cultural values.

Two examples, from the sixteenth and seventeenth centuries respectively, can serve here to vividly illustrate the potential afterlife of this kind of 'agency'; in this case the

\footnotetext{
${ }^{4} \mathrm{~A}$ critique of the still pervasive understanding of translation as a progression towards more sophisticated and 'faithful' translations is offered by Anthony Pym, Method in Translation History (Manchester: St Jerome Press, 1998, republished by Routledge, 2014 ) and C. Foz, 'Translation, History, and the Translation Scholar', in G. Bastin and P. Bandia (eds.), Charting the Future of Translation History (Ottawa: University of Ottawa Press, 2006), pp. 131-144.
}

${ }^{5}$ See the 2012 special issue of Translation Studies, dedicated to 'Rethinking Methods in Translation History' (Carol O'Sullivan, 'Introduction: Rethinking Methods in Translation History', pp. 131-138); Christopher Rundle, 'Theories and Methodologies of Translation History: The Value of an Interdisciplinary Approach', The Translator, 20 (2014), pp. 2-8. See also Marie-Alice Belle, 'At the Interface Between Translation History and Literary History: A Genealogy of the Theme of "Progress" in Seventeenth-century English Translation History and Criticism', The Translator, 20 (2014), pp. 44-63, and Marie-Alice Belle and Brenda M. Hosington, 'Translation, History, and Print: A Model for the Study of Printed Translations in Early Modern Britain', Translation Studies, 10 (2017), pp. 2-21.

${ }^{6}$ Moira Inghilleri, 'Mediating Zones of Uncertainty. Interpreter Agency, the Interpreting Habitus and Political Asylum Adjudication,' The Translator, 11 (2014), pp. 69-85, at p. 66. See also Michaela Wolf and Alexandra Fukari (eds.), Constructing a Sociology of Translation (Amsterdam and Philadelphia: John Benjamins, 2007), pp. $1-38$. 
influence of translators and the often unforeseeable momentum garnered by their work once it was circulated in print. In 1532, Charles V travelled to Mantua to meet with the ruler of that city, Federico II Gonzaga. The duke of Mantua took Charles V to Palazzo Te to admire the 'Sala dei Giganti', a great corner room which was at that moment being decorated by Giulio Romano: the frescoes show Jupiter the Avenger punishing the giants for waging war against him. ${ }^{7}$ This painted version of the story also depicts Pluto, the Furies, and monkeys, none of which feature in what should surely have been Romano's most obvious source, Ovid's Latin Metamorphoses. It would make sense to attribute this reinterpretation of Ovid's narrative to the artist himself, Giulio Romano. Instead, however, the figures of Pluto, the Furies, and monkeys were added to the story by a vernacular translator, Niccolò degli Agostini, in his 1522 rendering of the Metamorphoses into Italian. In this instance, the printed translation is the key text used by the artist in his visual and dramatic retelling of Ovid's narrative-Romano did not base his imagery on the Latin source. A century later, translator Jorge de Bustamante produced a Spanish version of Ovid's text that narrates Romulus and Remus nurtured by a bear rather than the more conventional she-wolf. As with Romano's frescoes in the Palazzo Te, this rewriting of the pagan myth follows closely the same vernacular version of Ovid's Metamorphoses compiled by Niccolò degli Agostini. ${ }^{8}$

The appearance of monkeys and bears in visual story-telling and literary texts, as sketched above, is the result of imaginative retranslation of ancient and medieval narrative sources. In the 'Sala dei Giganti', the figures of Pluto, the Furies, and monkeys remain as

\footnotetext{
${ }^{7}$ On Giulio Romano's frescoes see Frederick Hartt, Giulio Romano (2 vols., New Haven: Yale University Press, 1958), pp. 152-159; Egon Verheyan, The Palazzo del Te in Mantua: Images of Love and Politics (Baltimore and London: Johns Hopkins University Press, 1977); and Paula Carabell, 'Breaking the Frame: Transgression and Transformation in Giulio Romano's Sala dei Giganti', Artibus et Historiae, 18 (1997), pp. 88-100.

${ }^{8}$ Bodo Guthmüller, Ovidio Metamorphoseos Vulgare: Forme e funzioni della trasposizione in volgare della poesia classica nel Rinascimento italiano (Fiesole: Cadmo, 2008), pp. 13-19.
} 
indelible traces of vernacular translators. The monkeys comprise a scenographic detail that undoubtedly contributes to the fresco programme's dramatic appeal. Yet on a subtler level, they also alert viewers and readers to Agostini's creative flair, and, from there, to a widely theorised ideal of translative practice as one intelligently poised between learned imitation and rhetorical or poetic agency.

The retranslations of Ovid's Metamorphoses exemplify ways in which translations and retranslations could cross national, regional, and local contexts. They also reveal how translation often occurred in tandem with shifts in materials and technologies-from manuscript to print; from paper to plaster-or market - from the printed book trade to an exclusive artist-patron relationship, for instance. ${ }^{9}$ Images of all kinds, beliefs, and stereotypes were negotiated and 'carried' across different media and languages. Such a scope of reference for scholars of translation history poses fascinating challenges: we can find ourselves needing to confront very intricate interpretive work. Romano's frescoes demonstrate how translations also offered opportunities for translators, printers, artists, and patrons to redefine their role as intermediaries between ancient and contemporary texts and cultures. And collaborative translation - an interdependence of translators, whether alongside their contemporaries, or over generations - emerges strongly as a fundamental practice in the production of Renaissance translations.

\footnotetext{
${ }^{9}$ This process of adaptation of translation to a different medium has been recently described by Anne E. B. Coldiron as 'transmediation', and is examined closely by Richardson, Rizzi, and Calvillo in this volume: see Anne E. B. Coldiron, 'Response to "Translation and the Materialities of Communication"', Translation Studies, 9 (2016), pp. 96-102, at p. 99.
} 
It has been argued that the collaborative, transnational, and 'multimedia' nature of Renaissance translation requires an interdisciplinary approach. ${ }^{10}$ This collection of essays responds to that contention. It is manifestly interdisciplinary, entering into dialogue with book history, literary history, translation studies, cultural and social history, and art history, while also contributing to empirical and quantitative studies in translation history. ${ }^{11}$ A key objective has been to destabilise conventional notions of autonomous, individualised authorship, and of texts chiefly valued for their 'originality' of voice and vision.

\section{Translation, Retranslation, Cultural Translation}

Newly edited and translated works printed in the Renaissance frequently served as the impetus for further editions of the same texts, the production of which would often involve subtle but significant changes; these reworked texts have come to be referred to as 'active retranslations'. ${ }^{12}$ Historians of translation have recently emphasised the significance of retranslation in the investigation of literary practices and discursive strategies adopted by Renaissance translators and printers. ${ }^{13}$ The chapters in this volume deal directly or indirectly with retranslation as a matter of non-linear, often conflicting, reinterpretation-whether of written or visual materials. That is, retranslation is not presumed here as a progression towards 'better' version of the same text. ${ }^{14}$ Instead, translation and retranslation are

\footnotetext{
${ }^{10}$ See for instance Pym, Method in Translation History, pp. 198-199, O’Sullivan, 'Introduction', p. 136, and Brenda M. Hosington, 'Translation and Print Culture in Early Modern Europe', Renaissance Studies, 29 (2015), pp. $5-18$, at p. 12 .

${ }^{11}$ O’Sullivan, 'Introduction', p. 136.

12 Pym, Method, pp. 82-83.

${ }^{13}$ Belle, 'At the Interface Between Translation History and Literary History', p. 59.

${ }^{14}$ On retranslation as an object of enquiry for literary historians and translation studies scholars see Sharon Deane-Cox, Retranslation: Translation, Literature, and Reinterpretation (London, Oxford, and New York:
} 
considered practical, topical, and symbolic means of negotiating perceptions of language, and cultural understanding. And inherent to such negotiation is the agency claimed by or for those involved in producing translations.

Although translation, retranslation, and cultural translation can be described as interchangeable and often indistinguishable, it is worth briefly addressing the three categories, or distinctions. Translations and retranslations are difficult to differentiate, since translations are by nature never 'first', and are seldom based on a single start text, but rather an interpretation of a main work with echoes of, or explicit references to, other sources. Both medieval and Renaissance translative practices encompassed considerably more than the task of conveying the meaning of the translated author. Translators also acted as editors and authors, emending mistakes, and interpreting difficult passages by turning to earlier translations of the same text, or to variants of the start text. ${ }^{15}$ From this perspective, translations and retranslations can be said to enlarge the cultural and linguistic space occupied by an earlier translation: they create and expand a 'rhizomatic' space influenced by 'an intricate, entangled network of influences and agents'. ${ }^{16}$

Of course translators, printers, and other agents of translation always produce cultural commodities. Among scholars of literary and translation studies, however, the phrase

Bloomsbury Publishing, 2014). See the recent discussion of retranslation as a recovery of the start text in Andrew Chesterman, 'Hypotheses about Translation Universals', in G. Hansen etc. (eds.), Claims, Changes, and Challenges in Translation Studies (Amsterdam: Benjamins, 2004), pp. 1-13, at p. 8. The non-linear and non-progressive view of retranslation is supported by Anthony Pym, 'Shortcomings in the Historiography of Translation', Babel, 28 (1992), pp. 221-235.

${ }^{15}$ On the medieval translator as 'author' see Charles Burnett, 'The Translator as an Authority', in Pieter De Leemans and Michèle Goyens, The Medieval Translator. Traduire au Moyen Age (vols. 1-, Turnhout: Brepols, 2016), XVI, pp. 53-67.

${ }^{16}$ Deane-Cox, Retranslation, p. 10. 
'cultural translation' has been considered a slippery term for a kind of translation 'which does not involve two texts, or even one text, and certainly not more than one language'. ${ }^{17}$ Meanwhile anthropologists and cultural historians maintain that cultural translation encompasses a complex web of transfers and negotiations which are at once social, cultural, political, and linguistic. ${ }^{18}$ Like interlingual translation-the transference of a text from one language to another-cultural translation is a hermeneutic enterprise involving negotiation of power between agents of translation and the mediation of texts and contexts. With this broad definition in mind, cultural translation encompasses all modes of translation discussed in the ensuing chapters. Part II more specifically addresses the domestication of ideas and imagery across geographically different languages, and cultures. ${ }^{19}$

In this volume, the literary practices of translation, retranslation, and cultural translation are not examined archeologically (who translated what, where, and when), nor only through the lens of literary criticism (how the text was translated). The common aim is to investigate the rhetoric of self-presentation and self-promotion-including self-effacing statements - used by translators and printers to secure their social and financial success. To this end, Part I delves into different textual means adopted by translators, printers, and artists

${ }^{17}$ This definition is by Harish Trivedi, quoted in Sarah Maitland, What is Cultural Translation? (London, Oxford, and New York: Bloomsbury Publishing, 2017), p. 24. For a detailed summary of the debate around ‘cultural translation' see Maitland, What is Cultural Translation?, pp. 11-24.

${ }^{18}$ Peter Burke and R. Po-chsia Hsia (eds.), Cultural Translation in Early Modern Europe (Cambridge and New York: Cambridge University Press, 2007), pp. 8-9, and Federico M. Federici and Dario Tessicini (eds.), Translators, Interpreters, and Cultural Negotiators: Mediating and Communicating Power from the Middle Ages to the Modern Era (Houndmills and New York: Palgrave, 2014), pp. 2-4.

${ }^{19}$ On cultural translation see Peter Burke, Lost (and Found) in Translation: A Cultural History of Translators and Translating in Early Modern Europe (Wassenar: NIAS, 2005), at pp. 4-5, Boris Buden etc., 'Cultural Translation: An Introduction to the Problem, and Responses', Translation Studies, 2 (2009), pp. 196-219, and Maitland, What is Cultural Translation?, pp. 10-15. See Chapters 2, 4, 5, and 7 in this volume. 
with a view to 'enhancing their power to shape the culture of their own times'. ${ }^{20}$ Part II explores certain translation projects overtly premised on addressing a very specific readership, or 'imagined community', and the efforts expended to construct or at least frame this community in the detail of the printed work. Part III explores women translators and their works while simultaneously acknowledging and transcending cultural mores that circumscribed their intellectual authority.

\section{Collaborative Translation, Collaborative Dialogue}

Translators working in connection with the milieu of Renaissance print culture had recourse to a wide range of literary and artistic strategies of self-presentation and translation. Such strategies were inseparable from highly specific choices regarding material and artistic aspects of the early modern book (mise en page, typeface, printing technologies, paratextual elements such as annotations and corrections, decorative and figurative elements such as landscapes and portraits). More broadly, such strategies were in dynamic relationship with the socio-cultural and commercial contexts influencing production of text-objects. Indeed, words, images, mise en page, ink, and other material and artistic elements highlight the collaborative nature of Renaissance translation. Renaissance artists, authors, editors, printers, readers, and patrons as well as self-described translators all contributed to the conception, production, and transmission of translations.

Relatively little scholarly attention has been devoted to the collaboration between translators, printers, artists, and patrons in the production of translation during the Renaissance. ${ }^{21}$ Belén Bistué's 2013 study persuasively demonstrates collaboration as a

\footnotetext{
${ }^{20}$ Brian Richardson in this volume, at p.@@.

${ }^{21}$ On translators as negotiators of their own identity and of political, cultural, and literary texts see the already mentioned Federici and Tessicini (eds.), Translators, Interpreters, and Cultural Negotiators, and Tania
} 
feature of Renaissance translation. It has been followed by calls for studies that account for the physical, textual, visual, social, and economic elements that constituted translation in the Renaissance - calls for collaborative study of collaborative translation. ${ }^{22}$ This volume is the result of just such a dialogue between literary scholars, historians of translation, historians of the book and of art, about the many factors that fostered the flourishing of translation through the Renaissance. The dialogue began in Melbourne, in August 2015, on the occasion of a two-day international conference focused on collaboration between translators and printers in Renaissance Europe, as part of interrogating translators' role and self-image. ${ }^{23}$

The outcome is a transnational appraisal of many forms of evidence for agency and

Demetriou and Rowan Tomlinson (eds.), The Culture of Translation in Early Modern England and France, 1500-1660 (Basingstoke and New York: Palgrave Macmillan, 2015), and Hilary Brown, 'Rethinking Agency and Creativity: Translation, Collaboration, and Gender in Early Modern Germany', Translation Studies, 10 (2017), online version accessed on 23 April 2017. See also the groundbreaking study by Belén Bistué, Collaborative Translation and Multi-Version Texts in Early Modern Europe (Farnham: Ashgate, 2013). See also Deborah Uman and Belén Bistué, ‘Translation as Collaborative Authorship: Margaret Tyler’s The Mirrour of Princely Deedes abd Knighthood', Comparative Literature Studies, 44 (2007), pp. 298-323. Another significant and most recent contribution to the study of translation as a collaborative enterprise is Anthony Cordingley and Céline Frigau Manning (eds.), Collaborative Translation. From the Renaissance to the Digital Age (London, Oxford, and New York: Bloomsbury Publishing, 2017): see especially Cordingley and Céline Frigau Manning's, and Bistué's chapters.

${ }^{22}$ On the study of Renaissance translation as an object and its forms on the page see Guyda Armstrong, 'Coding Continental: Information Design in Sixteenth-Century English Vernacular Language Manuals and Translations', Renaissance Studies, 29 (2015), pp. 78-102. See also the discussion on materialities of communication spurred by Karin Littau, 'Translation and the materialities of communication', Translation Studies, 9 (2016), pp. 82-96, and Anne E. B. Coldiron, Printers without borders: translation and textuality in the Renaissance (Cambridge: Cambridge University Press, 2014), pp. 4-7.

${ }^{23}$ Trust and Proof: Translators in Early Modern Print Culture, Intenrational Conference at The University of Melbourne, 14-15 August 2015. 
collaboration in translations produced during the Renaissance. The studies gathered in this volume do not treat translations as relying on a single, reified, 'original' source (or the idea of such a source), but on various, complementary versions of pre-existing texts. Translations are inevitably reliant on various, complementary versions of pre-existing texts. When published, such 'serial' translations disseminated new possibilities for generating meaning. This practice heightened competition between translators, printers, and authors, as texts were successively modified and repurposed to appeal to discrete readers. 'Seriality' also denotes ongoing, nonlinear patterns of tradition and transmission of texts and ideas: these patterns entailed the production of several distinct translations of the same start text within a short period of time, or the reprinting of the same translation by the same or different printers. ${ }^{24}$

Contributions to this volume explore the patterns of expansion, reduction, and recalibration of start texts by analysing the discursive strategies used by translators and printers, and the materiality of translation - 'the physical, paratextual, bibliographical, and visual features' ${ }^{25}$ Even as the prefaces, dedicatory letters, and similar materials that tend to accompany Renaissance translations reveal a profoundly collaborative approach to the enterprise of translation, they also document marked anxieties — personal, cultural, political— associated with the task. ${ }^{26}$

\section{Print Culture}

Despite the strong recognition of the significance of early print technology and production, translators' contribution to the vitality of textual production in the Renaissance is still

\footnotetext{
${ }^{24}$ See Coldiron, Printers without borders, pp. 20-30.

${ }^{25}$ Armstrong, 'Coding Continental', p. 78.

${ }^{26}$ On the need to pay closer attention to retranslation as evidence of competition between translators and printers see most recently Marie-Alice Belle, 'At the Interface', p. 58.
} 
understudied. Happily, recent scholarship has begun to shed light on the significant role played by translators and printers in the development of vernacular European literatures. In particular, a transnational turn in literary history has spurred scholars to explore translation patterns, cultural and material exchanges, and collaboration beyond linguistic and political borders. ${ }^{27}$ Drawing on an extraordinary variety of sources published in Spanish, Portuguese, Italian, Latin, French, and English, this collection is pan-European in its range and compass. Especially through the prism of translators' and printers' first-person statements, the essays point out the extent to which language cultures were liable to shift, overlap, shrink, and expand during one of the most defining periods in the history of print culture.

The contributors to this volume examine translators' roles in the diffusion of discourse about languages and language-learning; ancient knowledge and ancient rhetoric; aesthetic appreciation; literature; faith and religion, as well as changing etiquettes of reading and writing. As far as possible the translators' own words about their purpose, skills, and projects are given close attention. The 'transcultural translators' discussed in this volume include artists (Francisco de Hollanda), Dominican priests, and printers. These figures did not focus exclusively on the word but also on visual elements of the texts.

Of course, by definition translation is never a transparent process; it is always shaped by the translator's understanding of the needs and desires of readers and patrons, which is sometimes made explicit, yet at other times remains unspoken. As such, this book has been shaped by questions about translators' perception and defence of their art. How did

${ }^{27}$ Early Modern Cultures of Translation; The Culture of Translation; Translation and the Book Trade; Coldiron, Printers without borders; Bistué, Collaborative Translation; Sara K. Barker and Brenda M. Hosington (eds.), Renaissance Cultural Crossroads: Translation, Print and Culture in Britain, 1473-1640 (Leiden: Brill, 2013); Brenda Deen Schildgen etc. (eds.), Other Renaissance. A New Approach to World Literature (New York and Houndmills, UK: Palgrave, 2006); Cultural Translation in Early Modern Europe; and Burke, Lost (and Found) in Translation. 
translators, printers, patrons, and artists—women and men—seek to guarantee the authority of their work? How did they work to construct their self-image at a time when their agency was being dramatically redefined by technologies of book production and trade? 


\section{FOREWORD}

\section{Translation, Print Technologies, and Modernity: Testing the Grand Narrative}

Anthony Pym

"We need more Bibles like that."

Musa Dube (2012)

Technologies, we know, strongly affect how we communicate, especially how we communicate from one language to another. In the case of print technologies, that general relationship can be thought about in terms of the following all-embracing narrative.

In Strasbourg, around 1440, Johannes Gutenberg's introduction of moveable type endowed texts with a degree of fixity. Printing allowed texts degrees of material survival over time and mobility through space, to an extent greater than did previous technologies. The new fixity, in turn, meant that translation could be ideologically based on an established "start text". This kind of translation thereby differed from the kind that had been just one among many forms of the general rewriting that produced variant copies, modifications and adaptations. Since print established the start in this way, there was "something there" to which a translation could be assumed to be faithful (or, in the twentieth century, equivalent). More important, the quality of this fidelity (or equivalence) was to the text as object—-before it was to an author or reader as person. And since fidelity was to a material thing instead of a person, it became a relationship into which potentially anyone could enter, if and when they had the required literacy. The spread of literacy thus allowed for more democratic access to knowledge and fewer restrictions on the right to translate. Print thus made possible a democratisation of knowledge, or so would run the narrative. 
The tale can be continued. Print brought about the need for linguistic conventions, and thus standardised languages, which tended to be the languages of the European nation state and its colonial counterparts. Since the emerging nation states developed a regime of mutual recognition based on a fiction of equality, their languages were also presumed to be of equal value - as as opposed to medieval regimes, where some languages were considered to be closer to divine revelation and hence superior. Rather than take knowledge from a superior to an inferior language, print-based translation was thus assumed to operate between equal languages. And that assumption reinforced the regime of fidelity (or equivalence), which was similarly based on a fiction of equality.

In sum, according to this story, the age of print would correspond to a particular way of thinking about translation: based on a start text; working between languages of potentially equal values; producing a text that ideally has a value equivalent to that of the start text; carried out by individuals. That general mode of thought was rarely found prior to the advent of print (if only because of the medieval hierarchy of languages), and was not common beyond Europe prior to the nineteenth century. It became important and coherent enough to be regarded as the Western form or mode of translation, which travelled out from Europe as one piece of that complex set of technologies and values known presumptuously as modernity.

Such might be the kind of grand narrative that is tested, implicitly, in all close analyses of translation in the age of print. It is tested well and closely by the contents of this volume.

\section{Print and Translation: A Test Case of Two Renaissance Bibles}

Here I would briefly like to test the same narrative on the basis of a particular historical comparison, just to see how it fares. The comparison concerns the Bible (but it might contain 
lessons for much else as well). And while it concerns Hispanic translation history, it hopefully resonates beyond.

One of the problems facing the Church in Hispania from the thirteenth century through to the fifteenth century was the presence of numerous vernacular variants of the biblical texts. Since the institutional authority of the Church was based on the Bible as book, different versions of that book — especially those held by the Jewish population prior to 1492 - undermined that authority. The problem would be addressed by the physical burning of variant texts: in Tarragona, for example, in 1233 (prior to print) and in the city of Salamanca in 1490 (in the age of print). Same problem, same solution, and the existence of print would appear to make no difference at all: a book burns as a book, no matter how the book has been produced.

There were other ways to address the problem, however. One of them was to locate the different versions, variants, and adaptations of the Bible and find out about them. The ensuing knowledge might then be used either to produce a corrected version or to enter into a disputation. That was the general spirit in which the Order of Calatrava organised a project, from 1422 to 1430 , to have Moses Arragel, rabbi of the Jewish community of Maqueda in Toledo province, translate the Hebrew biblical texts into Spanish. The result is the superb illustrated manuscript known as the Alba Bible (the "Biblia de Alba"), since it has long been owned by the House of Alba. A second attempted solution, which ran from 1502 to 1520 , was Cardinal Francisco Jiménez de Cisneros's project for a polyglot Bible based on linguistic scholarship — now known as the Complutensian Polyglot, which was printed. ${ }^{1}$ Both of these projects aimed to establish texts, albeit in different ways. One was pre-print; the other

\footnotetext{
${ }^{1}$ Francisco Jiménez de Cisneros (ed.), Vetus testamentū multiplici lingua nūc primo impressum (Alcalá de Henares: Copluti Universitate, 1514).
} 
occurred in the age of print (bearing in mind that the Gutenberg Bible was produced in 145055). What can these two projects tell us about print and translation?

Some differences are immediately obvious and eloquent. The Alba Bible was ordered as "una biblia en rromançe, glosada e ystoriada", that is to say, "a Bible in Romance [in this case Castilian Spanish], with glosses and explanations”. And indeed, for many of the pages there are more words in the commentaries than in the actual translation. The Complutensian Polyglot, on the other hand, establishes previous versions of the biblical text: Hebrew, Latin, and Greek for the Old Testament, with Aramaic Targum of Onkelos and its Latin translation, and then various etymologies and a Greek grammar, but no commentaries or explanations as such. So both volumes are presenting knowledge about the biblical text, but in very different ways. The Alba Bible presents the worldview of Hebrew as a relatively unknown language, offering particular explanations and interpretations: this is what the Hebrew-speaking rabbi can tell us, as a cultural informant for his time and place. The Complutensian Polyglot ostensibly presents no worldview beyond linguistic knowledge: it provides the tools with which a humanist could set about interpreting the text; it implicitly declares, "now you decide what you think". This difference in approach resonates with the kind of distinction that one would like to attribute to print and modernity: in making knowledge available on printed pages rather than through personal authority, the book opens to many possible interpretations, in a democracy of knowledge where all people potentially have the tools with which to decide.

If only history were that easy. Let us see how the effect of print actually works, for example on Isaiah 7:14. This verse can serve as a litmus test for any Bible translation: it is the place in which some believe the biblical text announces a virgin birth. The Hebrew has עלמה ('almah); Jerome's Latin Vulgate clearly has the word virgo (virgin); the Greek of the Septuagint has $\pi \alpha \rho \theta \varepsilon ́ v o \varsigma$ (young, unmarried woman, maiden, or virgin), and the 
Complutensian Polyglot efficiently aligns those three words with each other (the words share the same superscript numbers), so עלמה = virgo $=\pi \alpha \rho \theta \varepsilon$ vo in Isaiah, justifying another virgo later in Matthew 1:23. The text offers no particular gloss or explanation, but the message seems clear enough: the young woman was a virgin, because the little superscript numbers tell us there is linguistic equivalence at work.

The Alba Bible, which offers abundant commentaries, is rather more eloquent at this point. The glosses mention that the Hebrew word 'almah means "young woman", and the translating rabbi notes two possible versions in Spanish: moça (young woman, not necessarily a virgin) and virgen (virgin). The translator offers both these possibilities; the process of interpretation is not foreclosed, at least not in the commentary. Apparently the rendition as moça was not altogether an aberration: it also appears in some copies of the Ferrara Bible of 1553, which was commissioned and produced by Sephardic Jews. ${ }^{2}$ Nevertheless the Alba Bible bears traces of a spoken negotiation of sorts, most probably between the translator and his Christian correctors. The Christians certainly knew the young girl was supposed to be a virgin, and wanted her rendered as a virgen (as had been the case in Jerome and the Septuagint). The Jewish translator no doubt felt his correctors were imposing an interpretation that was inadequately justified by the Hebrew. So the solution he placed in the text borrowed a beautiful means of compromise from Jerome: when in doubt, transliterate. The Alba Bible has neither moça nor virgen but alma (soul), as a phonetic imitation of 'almah, which probably satisfied no one but was at least not unmotivated. The solution nevertheless seems not to have been won easily: Lazar remarks that a specific word,

\footnotetext{
${ }^{2}$ Moshe Lazar, "Moses as Translator and Commentator", in Jeremy Schonfield (ed.), Companion Volume to La Biblia de Alba. An Illustrated Manuscript Bible in Castilian (Madrid: Fundación Amigos de Sefarad; London:
} Facsimile Editions, 1992), 157-200, at 193. 
probably virgen, has been scratched from the parchment and replaced with alma. It was only after a debate of some kind that virginity was lost and the text found its soul.

Now, which of the two Bibles opens to greater diversity of intepretation? Both projects involved work by several hands, both took place in hierarchically controlled intercultural situations, but the manucript text in this case - the Alba Bible - actually does more to invite a plurality of interpretations. This principle is fairly explicit in the Jewish translator's own explanation of what he had done: "Since I have done no more than relate or record [memorar], everyone is left free to believe, debate [disputar] and defend their law as much as they can". ${ }^{3}$ That means, I suggest, that the oral debate has taken place within the production process, and the debate is being recorded for posterity, not just in the translated text but more importantly in the explanations and glosses. In the print text of the Complutensian Polyglot, however, those traces of oral debate have been lost: the materials may serve a future debate, perhaps, but the principle of visual equivalence (those neat columns; those little numbers that correspond) effectively pre-selects the material that can then be open to question.

Of course, there is much wrong with comparing these two projects in terms of any simple divide between "pre-print" and "print". The vernacular Bible, in this case, falls on the pre-print side, whereas print technology ushered in the age of Bibles in national languages. The more individualistic project is certainly the Alba Bible, much as one would like to associate the lone translator with print. Further, the mass distribution that one might like to associate with print was actually not the case for the Complutensian Polyglot, which proved to be very expensive and badly marketed, having been upstaged by the first published New Testament in Greek, Desiderius Erasmus's Novum Instrumentum omne of 1516. The

\footnotetext{
${ }^{3}$ Moses Arragel, (trans.), La Biblia de Alba. An Illustrated Manuscript Bible in Castilian (Madrid: Fundación Amigos de Sefarad; London: Facsimile Editions, 1992), fol. $15^{\mathrm{r}}$.
} 
comparison fails on all those points. Then again, changes associated with technologies rarely tend to be immediate, or at least immediately apparent. Technologies open ranges of possibilities, not obligatory imperatives, and their consequences can take centuries to become manifest; the best that historians might hope for is to identify long-term tendencies.

There is also the matter of ideas, which work with the technologies. Staying with the Hispanic frame, the eruption of humanist translation ideologies actually occurred slightly prior to the advent of print, most prominently in the epistolary debate between Alonso de Cartagena and Leonardo Bruni, from 1430 through to 1437. Cartagena was arguing for a translation procedure based on authority and tradition: a translation is good if it says what has to be said. Bruni replied on the basis of textual evidence: a translation is good if it provides what is in the start text. ${ }^{4}$ There is little doubt that, over stretches of history, Bruni won that debate. He set forth his position near the beginning of the regime that assumes an individual translator working on an individual fixed text and translating in a standardised national language (Bruni did not particularly want Greek in the middle of his Latin). That is, all the details more generally associated with the grand narrative of print-based modernity were effectively conceptualised and debated prior to Gutenberg's press. The technologies assuredly helped the fortunes of the ideas, but the ideas also had their day.

Moreover, the fact of print correlates with millennial sequences of historical steps, from the woodblocks of first-century China through to Gutenberg in the fifteenth century; then, more importantly, to the use of steam and the rotary press in the nineteenth century. Indeed, it was steam that most effectively enabled cheap mass production, books in public

\footnotetext{
${ }^{4}$ Alexander Birkenmajer, "Der Streit des Alonso von Cartagena mit Leonardo Bruni Aretino", in Clemens Baeumker (ed.), Vermischte Untersuchungen zur Geschichte der mittelalterlichen Philosophie (Munster: Aschendorff, 1922), 129-236.
} 
education, democratic access to knowledge, and the communicative factors of modernity. To project all of that back onto the Renaissance would be wishful thinking at best.

\section{Print-Based Fixity: Trust and Proof}

Yet our small textual comparison is perhaps not entirely in vain. The suggestions are that print may in some way help to conceal the spoken dialogues of knowledge production, that the very fixity of the text may in itself be limiting the variants of democratic debate, and that the fluidity of spoken debate is somehow closer to text in the pre-print era. These are all are propositions that demand to be tested. The testing is required in connection with the transition to print, but perhaps more intriguingly with regard to the post-print media in which we are now all involved. When we publish our translations in electronic form, there are few limits on how much of the production process can be included along with the text itself, and few material restrictions on what can be modified, when, and how often. There are only ecological limits on how many different translations can be accessed, and only weak social limits on who can participate in the processes of ongoing interpretation. Some of these features can be found, to varying degrees, in pre-print translation. And by investigating both ends of the trajectory traced by the correlation "pre-print" and "print", we might ascertain the more substantial import of print-based fixity.

To focus on print is to be invited to trust the printed text, which is its own "proof", as it were, gaining value as an object of collective investment. Trust the text; be faithful to the text; reproduce the truthful record. Prior to print, and later, such trust is more likely to be in the human mediators, the groups that come together to produce and move knowledge, and in the events that are dialogues between those actors. 
To close these broad reflections elicited by the scope of the present volume: an anecdote. At the Nida School of Translation Studies in 2012, the Botswanan feminist scholar Musa Dube argued that the offensively sexist passages in biblical texts should be changed: that is, eliminated, or made ideologically acceptable. ${ }^{5}$ Bob Hodgson and others from the Nida Institute then proposed the alternative solution of simply admitting that much of the social world of the Hebrew Bible and the early Christian Church is now simply obsolete: we should translate what is in the text, but then declare that we no longer live like that. Change the text, or change the interpretation? With a basis in opposed positions, that debate concerns theology, the unity of the sacred text, the role of textual scholarship, denominational belief, and particularly the political role of translation.

For the feminist scholar close to oral tradition and actual churches, the ideal is to have many different translations, each serving a different purpose in accordance with the needs of the receptive moment. To foster liberation, translators should change the non-liberating parts of the text. Yet there is a particular sequence involved: we have oral debate, and then the differences ensuing from that discussion become different translations, as orality begets variance in translation. On that view-which I suspect is to be found in pre-print and postprint translation cultures - the proof is the receptive event, and translators are to be trusted to convey the liberating values most appropriate to that event. For the culture of the fixed text, on the other hand, and so for a religion of scripture, the text is proof of itself, or indeed of its revelation; the text remains "the thing to be trusted" over and above that which any translator can do.

\footnotetext{
${ }^{5}$ See Musa Dube, “Translating for Liberation”, YouTube video, 29:58, Nida School of Translation Studies 2012, Lecture 3, uploaded by the San Pellegrino University Foundation, 13 August 2012, https://www.youtube.com/watch?v=tLyvXC18g4s. Accessed June 2016.
} 
That difference concerns far more than sacred texts: it concerns the importance of print technology in any account of translation history. 


\section{PREFACE}

\section{Andrea Rizzi and Cynthia Troup}

The 'grand narrative' of pre-print and print in medieval and Renaissance translation has begun to be challenged over the past decade. ${ }^{1}$ As part of his inspiring 'long view' of translation history, Anthony Pym rightly complicates notions of a chronological divide between 'pre-print' and 'print'. With reference to the aforementioned 'grand narrative', Pym points out that at the turn of the print age translation and translators are deemed to have fostered the emergence of source criticism and reconstruction (in Pym's phrase, the text as 'the thing to be trusted'). ${ }^{2}$ The refinement of philology is said to have enhanced confidence and interest in the texts on the part of Renaissance readers. ${ }^{3}$ According to another strand of the 'grand narrative', print technology stimulated the democratisation of knowledge and, inevitably, competition and collaboration between authors, printers, translators, editors, readers, and patrons.

Several aspects of the grand narrative rely on long-held assumptions about periodisation, progressive changes to translative practices, and national and transnational

\footnotetext{
${ }^{1}$ In this volume, the term 'Renaissance' is preferred to 'early modern'. We follow the view that 'Renaissance' indicates broadly "the intellectual, artistic, and cultural movements associated with that term" rather than "social, economic, and political structure and change" of the period 1400-1700. This distinction is however controversial and has been the subject of much discussion. See Jane Tylus and Karen Newman (eds.), Early Modern Cultures of Translation (Philadelphia: University of Pennsylvania Press, 2015), p. 266 n1.

${ }^{2}$ See Foreword in this volume.

${ }^{3}$ Rens Bod, A New History of the Humanities: The Search for Principles and Patterns from Antiquity to the Present (Oxford: Oxford University Press, 2013), pp. 352-353, and José María Fernández and Edward WilsonLee (eds.), Translation and the Book Trade in Early Modern Europe (Cambridge: Cambridge University Press, 2014), p. 13.
} 
paradigms. ${ }^{4}$ Such assumptions have been constructively challenged in recent journal issues and edited volumes concerned with the future of translation history and its methodologies. ${ }^{5}$ Taking heed of these discussions, the present volume embraces agency, identity, and technologies of production as its central focus. 'Agency' here refers to the strategies undertaken by Renaissance translators and printers - and others involved in the book market for translations - to position themselves and their work. ${ }^{6}$ Those involved in the production of translations tended to articulate their role, identity, and the work produced through the use of varied textual practices and other rhetorical means that were conditioned by social rules and cultural values.

Two examples, from the sixteenth and seventeenth centuries respectively, can serve here to vividly illustrate the potential afterlife of this kind of 'agency'; in this case the

\footnotetext{
${ }^{4}$ A critique of the still pervasive understanding of translation as a progression towards more sophisticated and 'faithful' translations is offered by Anthony Pym, Method in Translation History (Manchester: St Jerome Press, 1998, republished by Routledge, 2014 ) and C. Foz, 'Translation, History, and the Translation Scholar', in G. Bastin and P. Bandia (eds.), Charting the Future of Translation History (Ottawa: University of Ottawa Press,
} 2006), pp. 131-144.

${ }^{5}$ See the 2012 special issue of Translation Studies, dedicated to 'Rethinking Methods in Translation History' (Carol O'Sullivan, 'Introduction: Rethinking Methods in Translation History’, pp. 131-138); Christopher Rundle, 'Theories and Methodologies of Translation History: The Value of an Interdisciplinary Approach', The Translator, 20 (2014), pp. 2-8. See also Marie-Alice Belle, 'At the Interface Between Translation History and Literary History: A Genealogy of the Theme of "Progress" in Seventeenth-century English Translation History and Criticism', The Translator, 20 (2014), pp. 44-63, and Marie-Alice Belle and Brenda M. Hosington, 'Translation, History, and Print: A Model for the Study of Printed Translations in Early Modern Britain', Translation Studies, 10 (2017), pp. 2-21.

${ }^{6}$ Moira Inghilleri, 'Mediating Zones of Uncertainty. Interpreter Agency, the Interpreting Habitus and Political Asylum Adjudication,' The Translator, 11 (2014), pp. 69-85, at p. 66. See also Michaela Wolf and Alexandra Fukari (eds.), Constructing a Sociology of Translation (Amsterdam and Philadelphia: John Benjamins, 2007), pp. $1-38$. 
influence of translators and the often unforeseeable momentum garnered by their work once it was circulated in print. In 1532, Charles V travelled to Mantua to meet with the ruler of that city, Federico II Gonzaga. The duke of Mantua took Charles V to Palazzo Te to admire the 'Sala dei Giganti', a great corner room which was at that moment being decorated by Giulio Romano: the frescoes show Jupiter the Avenger punishing the giants for waging war against him. ${ }^{7}$ This painted version of the story also depicts Pluto, the Furies, and monkeys, none of which feature in what should surely have been Romano's most obvious source, Ovid's Latin Metamorphoses. It would make sense to attribute this reinterpretation of Ovid's narrative to the artist himself, Giulio Romano. Instead, however, the figures of Pluto, the Furies, and monkeys were added to the story by a vernacular translator, Niccolò degli Agostini, in his 1522 rendering of the Metamorphoses into Italian. In this instance, the printed translation is the key text used by the artist in his visual and dramatic retelling of Ovid's narrative-Romano did not base his imagery on the Latin source. A century later, translator Jorge de Bustamante produced a Spanish version of Ovid's text that narrates Romulus and Remus nurtured by a bear rather than the more conventional she-wolf. As with Romano's frescoes in the Palazzo Te, this rewriting of the pagan myth follows closely the same vernacular version of Ovid's Metamorphoses compiled by Niccolò degli Agostini. ${ }^{8}$

The appearance of monkeys and bears in visual story-telling and literary texts, as sketched above, is the result of imaginative retranslation of ancient and medieval narrative sources. In the 'Sala dei Giganti', the figures of Pluto, the Furies, and monkeys remain as

\footnotetext{
${ }^{7}$ On Giulio Romano’s frescoes see Frederick Hartt, Giulio Romano (2 vols., New Haven: Yale University Press, 1958), pp. 152-159; Egon Verheyan, The Palazzo del Te in Mantua: Images of Love and Politics (Baltimore and London: Johns Hopkins University Press, 1977); and Paula Carabell, 'Breaking the Frame: Transgression and Transformation in Giulio Romano's Sala dei Giganti', Artibus et Historiae, 18 (1997), pp. 88-100.

${ }^{8}$ Bodo Guthmüller, Ovidio Metamorphoseos Vulgare: Forme e funzioni della trasposizione in volgare della poesia classica nel Rinascimento italiano (Fiesole: Cadmo, 2008), pp. 13-19.
} 
indelible traces of vernacular translators. The monkeys comprise a scenographic detail that undoubtedly contributes to the fresco programme's dramatic appeal. Yet on a subtler level, they also alert viewers and readers to Agostini's creative flair, and, from there, to a widely theorised ideal of translative practice as one intelligently poised between learned imitation and rhetorical or poetic agency.

The retranslations of Ovid's Metamorphoses exemplify ways in which translations and retranslations could cross national, regional, and local contexts. They also reveal how translation often occurred in tandem with shifts in materials and technologies-from manuscript to print; from paper to plaster-or market - from the printed book trade to an exclusive artist-patron relationship, for instance. ${ }^{9}$ Images of all kinds, beliefs, and stereotypes were negotiated and 'carried' across different media and languages. Such a scope of reference for scholars of translation history poses fascinating challenges: we can find ourselves needing to confront very intricate interpretive work. Romano's frescoes demonstrate how translations also offered opportunities for translators, printers, artists, and patrons to redefine their role as intermediaries between ancient and contemporary texts and cultures. And collaborative translation - an interdependence of translators, whether alongside their contemporaries, or over generations - emerges strongly as a fundamental practice in the production of Renaissance translations.

\footnotetext{
${ }^{9}$ This process of adaptation of translation to a different medium has been recently described by Anne E. B. Coldiron as 'transmediation', and is examined closely by Richardson, Rizzi, and Calvillo in this volume: see Anne E. B. Coldiron, 'Response to "Translation and the Materialities of Communication"', Translation Studies, 9 (2016), pp. 96-102, at p. 99.
} 
It has been argued that the collaborative, transnational, and 'multimedia' nature of Renaissance translation requires an interdisciplinary approach. ${ }^{10}$ This collection of essays responds to that contention. It is manifestly interdisciplinary, entering into dialogue with book history, literary history, translation studies, cultural and social history, and art history, while also contributing to empirical and quantitative studies in translation history. ${ }^{11}$ A key objective has been to destabilise conventional notions of autonomous, individualised authorship, and of texts chiefly valued for their 'originality' of voice and vision.

\section{Translation, Retranslation, Cultural Translation}

Newly edited and translated works printed in the Renaissance frequently served as the impetus for further editions of the same texts, the production of which would often involve subtle but significant changes; these reworked texts have come to be referred to as 'active retranslations'. ${ }^{12}$ Historians of translation have recently emphasised the significance of retranslation in the investigation of literary practices and discursive strategies adopted by Renaissance translators and printers. ${ }^{13}$ The chapters in this volume deal directly or indirectly with retranslation as a matter of non-linear, often conflicting, reinterpretation-whether of written or visual materials. That is, retranslation is not presumed here as a progression towards 'better' version of the same text. ${ }^{14}$ Instead, translation and retranslation are

\footnotetext{
${ }^{10}$ See for instance Pym, Method in Translation History, pp. 198-199, O’Sullivan, 'Introduction', p. 136, and Brenda M. Hosington, 'Translation and Print Culture in Early Modern Europe', Renaissance Studies, 29 (2015), pp. 5-18, at p. 12 .

${ }^{11}$ O’Sullivan, 'Introduction', p. 136.

${ }^{12}$ Pym, Method, pp. 82-83.

${ }^{13}$ Belle, 'At the Interface Between Translation History and Literary History', p. 59.

${ }^{14}$ On retranslation as an object of enquiry for literary historians and translation studies scholars see Sharon Deane-Cox, Retranslation: Translation, Literature, and Reinterpretation (London, Oxford, and New York:
} 
considered practical, topical, and symbolic means of negotiating perceptions of language, and cultural understanding. And inherent to such negotiation is the agency claimed by or for those involved in producing translations.

Although translation, retranslation, and cultural translation can be described as interchangeable and often indistinguishable, it is worth briefly addressing the three categories, or distinctions. Translations and retranslations are difficult to differentiate, since translations are by nature never 'first', and are seldom based on a single start text, but rather an interpretation of a main work with echoes of, or explicit references to, other sources. Both medieval and Renaissance translative practices encompassed considerably more than the task of conveying the meaning of the translated author. Translators also acted as editors and authors, emending mistakes, and interpreting difficult passages by turning to earlier translations of the same text, or to variants of the start text. ${ }^{15}$ From this perspective, translations and retranslations can be said to enlarge the cultural and linguistic space occupied by an earlier translation: they create and expand a 'rhizomatic' space influenced by 'an intricate, entangled network of influences and agents'. ${ }^{16}$

Of course translators, printers, and other agents of translation always produce cultural commodities. Among scholars of literary and translation studies, however, the phrase

Bloomsbury Publishing, 2014). See the recent discussion of retranslation as a recovery of the start text in Andrew Chesterman, 'Hypotheses about Translation Universals', in G. Hansen etc. (eds.), Claims, Changes, and Challenges in Translation Studies (Amsterdam: Benjamins, 2004), pp. 1-13, at p. 8. The non-linear and non-progressive view of retranslation is supported by Anthony Pym, 'Shortcomings in the Historiography of Translation', Babel, 28 (1992), pp. 221-235.

${ }^{15}$ On the medieval translator as 'author' see Charles Burnett, 'The Translator as an Authority', in Pieter De Leemans and Michèle Goyens, The Medieval Translator. Traduire au Moyen Age, vols. 1- (Turnhout: Brepols, 2016), XVI, pp. 53-67.

${ }^{16}$ Deane-Cox, Retranslation, p. 10. 
'cultural translation' has been considered a slippery term for a kind of translation 'which does not involve two texts, or even one text, and certainly not more than one language'. ${ }^{17}$ Meanwhile anthropologists and cultural historians maintain that cultural translation encompasses a complex web of transfers and negotiations which are at once social, cultural, political, and linguistic. ${ }^{18}$ Like interlingual translation - the transference of a text from one language to another-cultural translation is a hermeneutic enterprise involving negotiation of power between agents of translation and the mediation of texts and contexts. With this broad definition in mind, cultural translation encompasses all modes of translation discussed in the ensuing chapters. Part II more specifically addresses the domestication of ideas and imagery across geographically different languages, and cultures. ${ }^{19}$

In this volume, the literary practices of translation, retranslation, and cultural translation are not examined archeologically (who translated what, where, and when), nor only through the lens of literary criticism (how the text was translated). The common aim is to investigate the rhetoric of self-presentation and self-promotion-including self-effacing statements - used by translators and printers to secure their social and financial success. To this end, Part I delves into different textual means adopted by translators, printers, and artists

\footnotetext{
${ }^{17}$ This definition is by Harish Trivedi, quoted in Sarah Maitland, What is Cultural Translation? (London, Oxford, and New York: Bloomsbury Publishing, 2017), p. 24. For a detailed summary of the debate around ‘cultural translation' see Maitland, What is Cultural Translation?, pp. 11-24.

${ }^{18}$ Peter Burke and R. Po-chsia Hsia (eds.), Cultural Translation in Early Modern Europe (Cambridge and New York: Cambridge University Press, 2007), pp. 8-9, and Federico M. Federici and Dario Tessicini (eds.), Translators, Interpreters, and Cultural Negotiators: Mediating and Communicating Power from the Middle Ages to the Modern Era (Houndmills and New York: Palgrave, 2014), pp. 2-4.

${ }^{19}$ On cultural translation see Peter Burke, Lost (and Found) in Translation: A Cultural History of Translators and Translating in Early Modern Europe (Wassenar: NIAS, 2005), at pp. 4-5, Boris Buden etc., 'Cultural
} Translation: An Introduction to the Problem, and Responses', Translation Studies, 2 (2009), pp. 196-219, and Maitland, What is Cultural Translation?, pp. 10-15. See Chapters 2, 4, 5, and 7 in this volume. 
with a view to 'enhancing their power to shape the culture of their own times' ${ }^{20}$ Part II explores certain translation projects overtly premised on addressing a very specific readership, or 'imagined community', and the efforts expended to construct or at least frame this community in the detail of the printed work. Part III explores women translators and their works while simultaneously acknowledging and transcending cultural mores that circumscribed their intellectual authority.

\section{Collaborative Translation, Collaborative Dialogue}

Translators working in connection with the milieu of Renaissance print culture had recourse to a wide range of literary and artistic strategies of self-presentation and translation. Such strategies were inseparable from highly specific choices regarding material and artistic aspects of the early modern book (mise en page, typeface, printing technologies, paratextual elements such as annotations and corrections, decorative and figurative elements such as landscapes and portraits). More broadly, such strategies were in dynamic relationship with the socio-cultural and commercial contexts influencing production of text-objects. Indeed, words, images, mise en page, ink, and other material and artistic elements highlight the collaborative nature of Renaissance translation. Renaissance artists, authors, editors, printers, readers, and patrons as well as self-described translators all contributed to the conception, production, and transmission of translations.

Relatively little scholarly attention has been devoted to the collaboration between translators, printers, artists, and patrons in the production of translation during the Renaissance. ${ }^{21}$ Belén Bistué's 2013 study persuasively demonstrates collaboration as a

\footnotetext{
${ }^{20}$ Brian Richardson in this volume, at p.@@.

${ }^{21}$ On translators as negotiators of their own identity and of political, cultural, and literary texts see the already mentioned Federici and Tessicini (eds.), Translators, Interpreters, and Cultural Negotiators, and Tania
} 
feature of Renaissance translation. It has been followed by calls for studies that account for the physical, textual, visual, social, and economic elements that constituted translation in the Renaissance - calls for collaborative study of collaborative translation. ${ }^{22}$ This volume is the result of just such a dialogue between literary scholars, historians of translation, historians of the book and of art, about the many factors that fostered the flourishing of translation through the Renaissance. The dialogue began in Melbourne, in August 2015, on the occasion of a two-day international conference focused on collaboration between translators and printers in Renaissance Europe, as part of interrogating translators' role and self-image. ${ }^{23}$

The outcome is a transnational appraisal of many forms of evidence for agency and

Demetriou and Rowan Tomlinson (eds.), The Culture of Translation in Early Modern England and France, 1500-1660 (Basingstoke and New York: Palgrave Macmillan, 2015), and Hilary Brown, 'Rethinking Agency and Creativity: Translation, Collaboration, and Gender in Early Modern Germany', Translation Studies, 10 (2017), online version accessed on 23 April 2017. See also the groundbreaking study by Belén Bistué, Collaborative Translation and Multi-Version Texts in Early Modern Europe (Farnham: Ashgate, 2013). See also Deborah Uman and Belén Bistué, 'Translation as Collaborative Authorship: Margaret Tyler’s The Mirrour of Princely Deedes abd Knighthood', Comparative Literature Studies, 44 (2007), pp. 298-323. Another significant and most recent contribution to the study of translation as a collaborative enterprise is Anthony Cordingley and Céline Frigau Manning (eds.), Collaborative Translation. From the Renaissance to the Digital Age (London, Oxford, and New York: Bloomsbury Publishing, 2017): see especially Cordingley and Céline Frigau Manning's, and Bistué’s chapters.

${ }^{22}$ On the study of Renaissance translation as an object and its forms on the page see Guyda Armstrong, 'Coding Continental: Information Design in Sixteenth-Century English Vernacular Language Manuals and Translations', Renaissance Studies, 29 (2015), pp. 78-102. See also the discussion on materialities of communication spurred by Karin Littau, 'Translation and the materialities of communication', Translation Studies, 9 (2016), pp. 82-96, and Anne E. B. Coldiron, Printers without borders: translation and textuality in the Renaissance (Cambridge: Cambridge University Press, 2014), pp. 4-7.

${ }^{23}$ Trust and Proof: Translators in Early Modern Print Culture, Intenrational Conference at The University of Melbourne, 14-15 August 2015. 
collaboration in translations produced during the Renaissance. The studies gathered in this volume do not treat translations as relying on a single, reified, 'original' source (or the idea of such a source), but on various, complementary versions of pre-existing texts. Translations are inevitably reliant on various, complementary versions of pre-existing texts. When published, such 'serial' translations disseminated new possibilities for generating meaning. This practice heightened competition between translators, printers, and authors, as texts were successively modified and repurposed to appeal to discrete readers. 'Seriality' also denotes ongoing, nonlinear patterns of tradition and transmission of texts and ideas: these patterns entailed the production of several distinct translations of the same start text within a short period of time, or the reprinting of the same translation by the same or different printers. ${ }^{24}$

Contributions to this volume explore the patterns of expansion, reduction, and recalibration of start texts by analysing the discursive strategies used by translators and printers, and the materiality of translation - 'the physical, paratextual, bibliographical, and visual features' ${ }^{25}$ Even as the prefaces, dedicatory letters, and similar materials that tend to accompany Renaissance translations reveal a profoundly collaborative approach to the enterprise of translation, they also document marked anxieties - personal, cultural, politicalassociated with the task. ${ }^{26}$

\section{Print Culture}

Despite the strong recognition of the significance of early print technology and production, translators' contribution to the vitality of textual production in the Renaissance is still

\footnotetext{
${ }^{24}$ See Coldiron, Printers without borders, pp. 20-30.

${ }^{25}$ Armstrong, 'Coding Continental', p. 78.

${ }^{26}$ On the need to pay closer attention to retranslation as evidence of competition between translators and printers see most recently Marie-Alice Belle, 'At the Interface', p. 58.
} 
understudied. Happily, recent scholarship has begun to shed light on the significant role played by translators and printers in the development of vernacular European literatures. In particular, a transnational turn in literary history has spurred scholars to explore translation patterns, cultural and material exchanges, and collaboration beyond linguistic and political borders. ${ }^{27}$ Drawing on an extraordinary variety of sources published in Spanish, Portuguese, Italian, Latin, French, and English, this collection is pan-European in its range and compass. Especially through the prism of translators' and printers' first-person statements, the essays point out the extent to which language cultures were liable to shift, overlap, shrink, and expand during one of the most defining periods in the history of print culture.

The contributors to this volume examine translators' roles in the diffusion of discourse about languages and language-learning; ancient knowledge and ancient rhetoric; aesthetic appreciation; literature; faith and religion, as well as changing etiquettes of reading and writing. As far as possible the translators' own words about their purpose, skills, and projects are given close attention. The 'transcultural translators' discussed in this volume include artists (Francisco de Hollanda), Dominican priests, and printers. These figures did not focus exclusively on the word but also on visual elements of the texts.

Of course, by definition translation is never a transparent process; it is always shaped by the translator's understanding of the needs and desires of readers and patrons, which is sometimes made explicit, yet at other times remains unspoken. As such, this book has been shaped by questions about translators' perception and defence of their art. How did

\footnotetext{
${ }^{27}$ Early Modern Cultures of Translation; The Culture of Translation; Translation and the Book Trade; Coldiron, Printers without borders; Bistué, Collaborative Translation; Sara K. Barker and Brenda M. Hosington (eds.), Renaissance Cultural Crossroads: Translation, Print and Culture in Britain, 1473-1640 (Leiden: Brill, 2013); Brenda Deen Schildgen etc. (eds.), Other Renaissance. A New Approach to World Literature (New York and Houndmills, UK: Palgrave, 2006); Cultural Translation in Early Modern Europe; and Burke, Lost (and Found) in Translation.
} 
translators, printers, patrons, and artists - women and men — seek to guarantee the authority of their work? How did they work to construct their self-image at a time when their agency was being dramatically redefined by technologies of book production and trade? 


\section{CHAPTER 1}

\section{The Social Transmission of Translations in Renaissance Italy:}

\section{Strategies of Dedication}

\section{Brian Richardson}

In early modern Italy, most translations, like other works, were published socially: that is, the process of public diffusion was often initiated by the author or some other person, whether in manuscript or in print, through an act of giving to a chosen first reader that was usually made evident to subsequent readers. This act would often have involved the material presentation of a copy of the translated text to the first reader. More importantly from the point of view of the great majority of readers, it also took the form of a dedication with a donative function. This was made widely visible through the use of accompanying paratexts: chiefly a letter of dedication, and sometimes also a mention of the dedicatee on the title page in the case of a printed book. How might this practice have influenced the reception of the translation, and how might it have helped to shape the image of the translator in the eyes of others, especially with reference to tothe issue of trust? What were the effects of dedicating a version of a text from another language, and usually from another culture and another time, to a person who belonged to the contemporary world? This chapter considers a range of translations, mainly into the Italian vernacular, in order to suggest some answers to these questions.

\section{Generating Authority; Defending the Translator's Work}

The need to generate authority for a text and to defend it against possible criticism was probably more acute for translators than for other authors, because their task was open to accusations of untrustworthiness. In addition, when they were working from a classical language into the less prestigious Italian vernacular, their task was open to accusations of 
"dumbing down", of reducing high culture to the level of those not fortunate enough to have a reading knowledge of the original language. In this respect, a strategy frequently used by dedicators was to associate the translation with the social authority of the dedicatee. One way of doing this was simply to describe the dedicatee as praiseworthy, so that the translation was viewed by others as bathed in the light reflected from his or her glory. In the late fifteenth century, Matteo Maria Boiardo could present his vernacular versions of Latin and Greek texts as exemplifications of the power and achievements of members of the Este family, who ruled the state of Ferrara to which he belonged. Boiardo himself says his translation of the Historia imperiale by Riccobaldo Ferrarese, made in the early 1470s, belongs to Duke Ercole d'Este because,

oltro che io cum tutte le cose mie sia per obligo di quella [Vostra Signoria], fu Riccobaldo, da cui è tratta questa opera, di vostra citade e bona parte del libro è repieno de' magnanimi gesti e prudentissimi governi de li antiqui vostri passati.

(not only am I with all my possessions under an obligation to you, but Riccobaldo, from whom this work is taken, came from your city and much of the book is full of the magnanimous deeds and most prudent political measures of your late ancestors.) ${ }^{1}$

The same kind of association was made in 1518, long after Boiardo's death, when his version of Apuleius (Apulegio volgare) was printed in Venice: the printer Nicolò Zoppino, in his letter of dedication to the current duke of Ferrara, Alfonso d'Este, hardly mentions the creator

\footnotetext{
${ }^{1}$ Andrea Rizzi (ed.), The 'Historia imperiale' by Riccobaldo Ferrarese Translated by Matteo Maria Boiardo (1471-1473), (Rome: Istituto storico italiano per il Medio Evo, 2008), pp. 3-4 at p. 4, punctuation modified. Unless otherwise acknowledged, all translations in this chapter are by Brian Richardson.
} 
of the source text, who is simply described briefly as an "antiquo et sapiente auctore" (“ancient and wise author"). Instead he devotes almost all the letter to praise of Alfonso's ancestors and then of Alfonso himself, "prole degna di tanti progenitori, et in niuna parte inferiore a le laude loro" ("offspring worthy of such ancestors and in no way inferior to their praises"). ${ }^{2}$ The Golden Ass thus acquired a partial resemblance to a contemporary romance, Ludovico Ariosto's Orlando furioso, first printed in Ferrara in 1516, which opened with praise of Alfonso's brother Ippolito and included several flattering references to Alfonso and to the Estense dynasty.

In other cases the authority bestowed by the dedicatee is invoked explicitly. Thus Bernardo Pulci writes of the "auctorità" conferred by Lorenzo de' Medici on his verse translation of Virgil's Eclogues, printed in 1482: he sends it to Lorenzo not in order to enlighten him, since of course Lorenzo understands the Latin original perfectly, “[m]a perché dal tuo medesimo florentissimo nome a essa operetta non mediocre auctorità ne venga a resultare" ("but so that from your most flourishing name no small authority should redound to this little work"). ${ }^{3}$ The printer Giovanni Francesco Torresani dedicates to Jean Grolier in 1544 his own edition of Giovanni Giustiniani's verse translation of the Andria and Eunuchus of Terence with the comment that the bibliophile and treasurer-general of France brings authority to this book and others:

Per questa causa principalmente diamo fuori Terentio sotto il nome vostro, acciò che et egli, e tutte le altre cose nostre che sono uscite, o usciranno al cospetto de gli

\footnotetext{
${ }^{2}$ Cited in Edoardo Fumagalli, Matteo Maria Boiardo, volgarizzatore dell 'Asino d'oro': Contributo allo studio della fortuna di Apuleio nell'umanesimo (Padua: Antenore, 1988), p. 2.

${ }^{3}$ Bucolica (Florence: Antonio di Bartolommeo Miscomini, 1481/2), fol. A4 ${ }^{\mathrm{r}}$.
} 
huomini: sieno dal vostro patrocinio, et protettione diffesi: et dal vostro nome si aggiunga non poco di authoritade a' libri nostri.

(For this reason above all we are publishing Terence under your name: so that both he and all the other works of ours that have, or will, come out in the sight of men may be defended by your patronage and protection, and so that by your name no little authority may be added to our books. $)^{4}$

Here Torresani introduces a motif related to the dedicatee's authority, that of the dedicatee as someone who can disarm critics or act as advocate for the translation. This idea is given great prominence by Ippolita Clara, who published only in manuscript. She opens the letter of dedication, dated 1533, of her verse translation of Aeneid I-VI to Francesco II Sforza, duke of Milan, with an analogy between a combattant's need for "uno accorto et degno padrino" (“a wise and worthy second") and an author's need for defence by a great and honoured man. She depicts herself as a "donna indotta" ("uneducated woman") who is presenting a work even though its style is not polished: "ben . . . ch'io veda anchora tal mia opera povera del florido toscano parlare et forse con migliaia d'errori che 'l mio debil occhio non vede" ("although I still perceive that this work of mine is poor in the flourishing Tuscan tongue and perhaps has thousands of errors that my weak eye does not see”). However, Clara says, if her chosen dedicatee accepts her work,

\footnotetext{
${ }^{4}$ L'Andria, et l'Eunucho di Terentio, tradotte in verso sdrucciolo per messer Gio. Giustiniano di Candia (Venice: Giovanni Francesco Torresani, 1544), fols. ${ }^{*} 5^{\mathrm{r}}-* 8^{\mathrm{v}}\left(\right.$ fol. ${ }^{*} 8^{\mathrm{r}}-\mathrm{v}$ ). On the links between Torresani and Grolier, see Anthony Hobson, Renaissance Book Collecting: Jean Grolier and Diego Hurtado de Mendoza, their Books and Bindings (Cambridge: Cambridge University Press, 1999), pp. 44-45, 59, 61, 65.
} 
sono certa [che questa] con tale e tanta difesa vie più liberamente se n'anderà, per che le cose che alto sono dicate, ben che minime siano, pur sono da molti per riverenza del suo alto signor risguardate, et reverite molto.

(I am certain that with such a strong defence it will go forth much more freely, for writings that are dedicated on high, however lowly they may be, are still regarded by many with reverence for their high lord and greatly revered").

Clara explains that she has translated Virgil "per essempio alle indotte donne" ("to provide examples for uneducated women"), and goes on to say to the duke: "pregoli anchora per sua innata humanità . . . la se degni accettarla et da le latranti lingue con il scuto de la sua prudenza difenderla" ("I also beg you, through your innate humanity, to deign to accept it and to defend it from baying tongues with the shield of your prudence"). ${ }^{5}$

Even experienced translators had recourse to invoking the protection of the dedicatee. The Florentine Antonio Brucioli wrote to Cardinal Ercole Gonzaga that he was placing the "pane celestiale" ("celestial bread") of his translation of the New Testament, in the edition of 1530 (Venice: Lucantonio Giunta), “[s]otto la fidatissima tutela di V. R. S. avanti alla mensa delle pie menti vulgari" (fol. $+8^{\mathrm{v}}$; "under the most trusted protection of your most reverend lordship before the table of vernacular pious minds. Brucioli refers somewhat negatively to the practice of using such a defence for self-advancement in his dedication of Aristotle, Libri tre dell'anima (Venice: Francesco Imperatore, 1557), to Cardinal Carlo Carafa:

\footnotetext{
${ }^{5}$ Madrid, Real Biblioteca del Escorial, MS f-IV-17, fols. III ${ }^{\mathrm{r}}-\mathrm{IV}^{\mathrm{v}}$. The letter of dedication is published in Simone Albonico, Ordine e numero: Studi sul libro di poesia e le raccolte poetiche nel Cinquecento (Alessandria: Edizioni dell'Orso, 2006), pp. 95-122, at pp. 120-121.
} 
quegli, che dedicano le loro compositioni a gran signori, gli laudono, et celebrano, per mostrare, come porta la ragione, di havere eletto honorato protettore delle loro fatice, sotto il nome del quale venghino più riguardevoli.

(fol. $\pi 2^{\mathrm{v}}$; "those who dedicate their works to great lords praise and celebrate them in order to show, rightly, that they have chosen an honoured protector of their labours, under whose name they may gain greater respect").

A prolific translator from the mid-sixteenth century, the Dominican friar Remigio Nannini chooses as the dedicatee of his version of Ammianus Marcellinus's Res gestae, printed in 1550, the young Antonio Altoviti (1521-73), archbishop of Florence, as someone who will defend the work on his behalf:

Ho cercato finalmente di qualche singolar personaggio, il quale non pure l'havesse grata [questa impresa], ma potesse et sapesse anchora pigliar la sua difesa. Dove dopo molto pensarvi, mi son risoluto alla fine intitolarla a V. S. Reverendissima, la quale essendo hoggidì nella patria nostra non meno illustre per dottrina et per sapere, che chiara per honore et per fortuna, spero che devrà gradire et difendere questa mia fatica.

(Finally I sought some illustrious person who would not only appreciate [this undertaking] but who also could and would know how to take up its defence. After much thought, I decided in the end to dedicate it to your most reverend lordship, and I hope that you, who are nowadays in our state no less illustrious for your learning and 
knowledge than renowned for your honour and fortune, will appreciate and defend this labour of mine.) ${ }^{6}$

But why should the friar have felt in need of defence? The reasons for this emerge in the first part of his letter to Altoviti, which illustrates another aspect of translators' strategies of dedication: the use of such letters, sometimes in preference to a separate preface or a letter addressed to the reader in general, in order to justify their approach. A translator who discusses his or her methodology in this way is at the same time revealing anxieties about the target text, and implying that the authority of the dedicatee should dissuade others from criticising this text. Nannini, in his dedication of Ammianus, likens himself to an unskilled painter who has not done justice to his subject. However, he also offers some selfjustification to his many potential critics:

Che sì come i mal esperti dipintori nel ritrarre o huomini o donne vive, o statua $\mathrm{o}$ disegno di miglior maestro ch'essi non sono, non le rappresentano a punto, ma buona parte scemano della natural loro bellezza, non si partendo però dalla lor conosciuta sembianza: così io quantunque non mi sia allontanato da Ammiano, confesso però di non havere arrivato alla purità sua. ... Et forse anchora havendol'io in qualche parte sostenuto, abbellito, inalzato, aiutando l'arte sua con la mia, ne averrà per ventura, che molto più volentier rimireranno questo mio ritratto, che la prima forma, onde egli è

\footnotetext{
${ }^{6}$ Delle guerre de' romani. Tradotto per M. Remigio Fiorentino (Venice: Gabriele Giolito, 1550), fol. *4r. Angelo Caiani had sent to Altoviti his version of I quindici libri degli elementi di Euclide, di greco tradotti in lingua thoscana (Rome: Antonio Blado, 1545) so that it should be published "sotto l'ombra del nome vostro" (fol. $\mathrm{A} 2^{\mathrm{r}-\mathrm{v}}$; "under the protection of your name").
} 
compreso et tradotto. ... [E] hora aprendo io lor questa nuova porta, fo palese a tutti gli altissimi concetti di questo Illustre scrittore.

(For, just as inexpert painters, when depicting living men or women, or a statue or a drawing by a better master than themselves, do not represent them exactly but diminish much of their natural beauty, without however departing much from their recognised appearance, so I confess that, although I have not gone far from Ammianus, I have nevertheless not attained his purity. . . . And perhaps, too, if I have in some measure supported, embellished, raised him, helping his art with mine, the result may be that they will look much more willingly on this portrait of mine than on the original form from which it is understood and translated. ... And now by opening this new door to them, I am making evident to all the most lofty thoughts of this illustrious writer. $)^{7}$

Moreover, Nannini claims, he has enriched the Tuscan language with this treasure. ${ }^{8}$ At the beginning of the sixteenth century, Pietro Ragnoni used his dedication to Pandolfo Petrucci, the leading citizen of the republic of Siena, in order to justify his version of a work then attributed to Pliny the Younger, De li homini illustri in lingua senese traducto et brevemente commentato (Siena: Simone Nardi, 1506). Ragnoni claims he is publishing this solely to please Petrucci, who is thus given some credit but also some responsibility for this dissemination. Ragnoni goes straight on to mention the nature of his work, using the metaphor of translation as rebuilding. So as to create trust in his text, he says that he has followed the "pure source" of the Latin original as closely as possible, but he clearly feels a

\footnotetext{
${ }^{7}$ Delle guerre de' romani, fol. $* 3^{\mathrm{r}-\mathrm{v}}$.

${ }^{8}$ Delle guerre de' romani, fols. $* 3^{\mathrm{v}}-* 4^{\mathrm{r}}$.
} 
lack of confidence in his Sienese language - a form of Tuscan somewhat different from the Florentine of the canonical fourteenth-century authors:

Et perché al traducto non minor fede che al proprio exemplare sia prestata, quasi le proprie vestigie rebattendo (quantunche questo sia più difficile, per la molta discrepantia quale è tra la lingua pura latina e peculiare nostra senese), dal puro fonte apena alontanatomi, con più clara descriptione tal fabrica reformarsi non cognoscevo (fol. $\mathrm{A} 2^{\mathrm{r}}$ ).

(And so that the translation should be trusted no less than the source text itself, as if one were going back over one's footsteps (although this is more difficult because of the great discrepancy between the pure Latin language and our particular Sienese language), departing hardly at all from the pure source, I was unable to rebuild this edifice with a clearer representation).

By explaining this in his letter of dedication, Ragnoni can at the same time apologise for his perceived shortcomings while using the political authority of Petrucci as a form of selfprotection.

\section{Defending Vernacular Translation}

Some translators used their dedicatory paratexts to defend the act of vernacular translation in general. Sebastiano Manilio, who worked in Venice as a translator and editor, addressed the preface of his version of Seneca's letters to Ludovico Sforza, duke of Milan, and he 
incorporated in it a robust defence of all translations from Latin to the vernacular. ${ }^{9} \mathrm{He}$ pointed out to critics that the process was parallel to that of translating Greek into Latin:

Dicono adonque che si fa ingiuria e detrahesi alla fama delli latini scrittori convertendo in parlar comune quello che loro in latino han lasciato scritto. Ma io domando loro: che ingiuria sia stata fatta a Platone, ad Herodoto, a Plutarco et a tutti gli altri greci e philosophi et oratori et historici e poeti li quali in lingua latina sono stati convertiti? Non hanno conseguita magior gloria e fama essendo dati a cognoscere a molti più che prima?

(They say, therefore, that turning into the common language what Latin writers have written in Latin harms and detracts from their fame. But I ask them: what harm has been done to Plato, Herodotus, Plutarch and all the other Greeks and philosophers and orators and historians and poets who have been turned into the Latin language? Have they not gained greater glory and fame through being made known to many more people than before? $)^{10}$

Why should Seneca not be known to "[la] volgar turba" ("the common herd"), Manilio asked? What he was doing was, he argued, for "la comune utilità" ("the common benefit"). ${ }^{11}$ As already discussed, dedicators might share their thoughts on the capacity of the vernacular to provide an equivalent of Latin texts. On the one hand, when Lodovico Domenichi dedicated to Catherine de' Medici — queen of France but of course a Florentine by

\footnotetext{
${ }^{9}$ Pistole del moralissimo Seneca (Venice: Sebastiano Manilio, and Stefano and Bernardino de' Nalli, 1494).

${ }^{10}$ Pistole del moralissimo Seneca, fol. ** $1^{\mathrm{r}-\mathrm{v}}$.

${ }^{11}$ Pistole del moralissimo Seneca, fol. **1 $1^{\mathrm{v}}$.
} 
birth - his translation of Paolo Giovio's histories, Dell'historie del suo tempo (Florence: Lorenzo Torrentino, 1551), he told her that he was embarrassed about the relative poverty of the vernacular, and his need to use more words in order to provide the same meaning. ${ }^{12} \mathrm{He}$ may be referring to Latin as a synthetic language, using inflections and not having compound tenses, or to the lack of precise vernacular equivalents for some Latin terms. He writes:

Dunque humilmente la supplico, che si degni ricevere in grado la mia buona volontà, se l'opra in tutto non sarà conforme al desiderio, ch'io ho di sforzarmi di rappresentare in parlar Thoscano con dignità la propria elegantia dell'idioma Latino. Il qual confesso così per il nervo della testura spessa et serrata de' pieni et ponderosi vocaboli, quanto per la povertà in simil materia della Volgar lingua, essere cosa difficile di tradurre a misura: essendo necessario moltiplicare in parole, per render più chiaro il senso dell'Authore (fol. $2^{\mathrm{r}-\mathrm{v}}$ ).

(I therefore humbly beg you to receive willingly my goodwill, if the work does not completely conform with my desire to try to represent worthily in Tuscan the innate elegance of Latin. I confess that it is hard to translate this adequately, both because of the sinews of the thick and dense weaving of the full and weighty words and because the vernacular is poor in such subject matter; instead, one has to multiply words to make the author's sense clearer).

On the other hand, three years later Benedetto Varchi included a vigorous justification of vernacular translation when he presented his version of Seneca's treatise De beneficiis to

\footnotetext{
${ }^{12}$ Giovio approved of Domenichi's translations of his works: see T. C. Price Zimmerman, Paolo Giovio: The Historian and the Crisis of Sixteenth-century Italy (Princeton: Princeton University Press, 1996), p. 246.
} 
Eleonora de Toledo, duchess of Florence. ${ }^{13}$ Whereas Domenichi, from northern Italy, saw the Florentine-based vernacular as poorer than Latin, the Florentine Varchi insisted that it was a natural heir to Greek and Latin, thanks to the cultural policies of Eleonora and above all of her husband Duke Cosimo, and that the language was at least capable of further enrichment:

questo divino Autore ... non doverrà haver per male, anzi molto a grado d'essere per comune utilità, et publico benifizio, in quella lingua tradotto, la quale così si vede hoggi succedere alla Latina, come la Latina successe anticamente alla Greca, del che, sì a V. E. et sì massimamente a quella di V. Illustrissima Sig. et Marito, deve saperne non picciolo grado per quelle cagioni, che altrove si sono raccontate assai lungamente. Et di vero, o egli solo, o nessuno altro Principe nè può, nè deve nè con maggiore agevolezza condurla a quella riputazione, et quasi maestà, di che ella è capevole, così per la ineffabile dolcezza sua come per l'incomparabile gravità, nè più felicemente inalzarla a quel colmo, dove ella non tanto per l'esser abbondevole, et ricca, quanto

\footnotetext{
${ }^{13}$ Seneca, De' benefizii tradotto in volgar fiorentino da messer Benedetto Varchi (Florence: Lorenzo Torrentino, 1554). On Varchi as translator, see Dario Brancato, 'Benedetto Varchi traduttore di Boezio', in ed. Vanni Bramanti (ed.), Benedetto Varchi (1503-2003): Atti del convegno (Firenze, 16-17 dicembre 2003) (Rome: Edizioni di Storia e Letteratura, 2007), pp. 95-155; Dario Brancato, 'La lettera dedicatoria della Consolazione della filosofia di Benedetto Varchi e le teorie linguistiche tardocinquecentesche', Studi rinascimentali, 1 (2003): pp. 83-93; Dario Brancato, 'Readers and Interpreters of the Consolation in Italy, 1300-1550', in Noel H. Kaylor and Philip E. Phillips (eds.), A Companion to Boethius in the Middle Ages (Leiden: Brill, 2012), pp. 357-411; Dario Brancato, 'Becoming a Classic: Benedetto Varchi’s Boezio (1551) and "the language of Florence"”, in Federico M. Federici and Dario Tessicini (eds.), Translators, Interpreters and Cultural Negotiators: Mediating and Communicating Power from the Middle Ages to the Modern Era (New York: Palgrave Macmillan, 2014), pp. 48-61; Annalisa Andreoni, La via della dottrina: Le lezioni accademiche di Benedetto Varchi (Pisa: ETS, 2012), pp. 23-24; Marco Sgarbi, The Italian Mind: Vernacular Logic in Renaissance Italy (1540-1551) (Leiden: Brill, 2014), pp. 85-89.
} 
per lo non esser povera, e manchevole, può se non senza difficultà, almeno senza dubitazione arrivare.

(this divine author should not be upset, but rather very grateful, that he has been translated for common usefulness and public benefit into that language that today we see succeeding Latin, just as Latin succeeded Greek in ancient times. For this he must be in no small measure grateful both to your excellency and especially to your most illustrious husband, for the reasons that have been set out at great length elsewhere. And in truth only he and no other prince can or must more easily bring it to that reputation and near-majesty of which it is capable through both its ineffable sweetness and its incomparable gravity; no one else can more successfully raise it to the height that it can reach — if not without difficulty, at least without doubt—not so much through its abundance and richness as through its not being poor and lacking.) $)^{14}$

Dedicatory letters were considered appropriate places for observations such as those of Domenichi and Varchi about the need for translation, but also for comments about the need for creativity on the part of translators, with the added benefit of developing the vernacular. Rather than addressing their views on their work directly to the reader, outside any cultural context, translators could present them as if in a private conversation with a sympathetic figure of authority, while still making them public. This example also features mention of the ancient author as if he were living, personally and emotionally involved in the new life of his text.

\footnotetext{
${ }^{14}$ Quotation from the edition of Florence: heirs of Bernardo Giunta, 1574, fol. a3 ${ }^{\mathrm{r}}$. "Altrove" may refer in part to Varchi's dedicatory letter, addressed to Cosimo, of the Florentine edition of Bembo's Prose della volgar lingua (Florence: Torrentino, 1548-49), fols. $\mathrm{A} 2^{\mathrm{r}}-\mathrm{A} 4^{\mathrm{r}}$.
} 
Varchi informed readers at the start of his letter to the duchess that he had translated Seneca at her request, made through Pietro de Toledo, her late father and former viceroy of Naples. When translators credited a dedicatee in this way as the begetter of the translation, they represented her or him as culturally enlightened, while also sharing with the dedicatee the responsibility for the text. At the same time, they needed to be tactful and avoid any implication that the recipient was not capable of understanding the source text, even if this was actually the case. As indicated above, Bernardo Pulci stated that Lorenzo de' Medici had no need for his translation of Virgil; Ippolita Clara said to Duke Francesco Sforza that "io [sono] certa molto più la lingua latina piacerti ch'ogni volgare e dotto stile" ("I am sure you like the Latin language much more than any vernacular and learned style"). ${ }^{15}$ When Boiardo translated texts into the vernacular for Duke Ercole, who had no Latin, he was careful to say that he was working for the common good; for instance, when he dedicated Riccobaldo's Historia imperiale to the duke, he wrote that "ho deliberato tradure a la vulgar gente da lingua Latina, aciò che il cognoscere de le passate cose, il quale è utilitade comune, più comunamente sia posseduta" ("I decided to translate for uncultured people from Latin, so that knowledge of past things, which is of common benefit, may be more commonly owned"). ${ }^{16}$ The claim of translating for the common good was also made by Varchi, as outlined above. Giuseppe Betussi attributed this idea to his patron Count Collaltino Collalto when, in 1547 , he dedicated to him his version of Boccaccio's Genealogia deorum gentilium. ${ }^{17}$ The count was a professional soldier but also a poet, and he presumably knew Latin. Betussi stresses that Collaltino commissioned the task for the good of others: he writes of "la tradottione mia ... che già fa l'anno, et più V. S. mi pose in core che non per sé, ma per utile

\footnotetext{
${ }^{15}$ Madrid, Real Biblioteca del Escorial, MS f-IV-17, fol. III' ${ }^{\mathrm{r}}$.

${ }^{16}$ Riccobaldo Ferrarese, The “Historia imperiale”, p. 4. See Fumagalli, Matteo Maria Boiardo, pp. 92-93.

${ }^{17}$ La geneologia de gli dei de’ gentili (Venice: Comin da Trino for Andrea Arrivabene, 1547).
} 
commune io dovessi fare" ("my translation that over a year ago you set it in my heart to make, not for yourself, but for the common benefit"). ${ }^{18}$

Connected with the self-image of translators as persons who are working to assist others is their avoidance of expressing even implicitly any expectation of personal benefit, although in all societies, as Marcel Mauss showed, in the gesture of a gift "really there is obligation and economic self-interest". ${ }^{19}$ When Brucioli presents his version of the New Testament to the French king François I in 1532, he dismisses the culture of worldly giftgiving, stressing that the Bible in the vernacular is a real treasure, the most valuable gift that anyone can give: "Et tengo per certo che niente più charo, et niente più accetto gli habbia a essere, di questo divinissimo libro come vero Christo del Signore Christo Giesù” (“And I am certain that nothing can be dearer and more welcome to you than this most divine book, as the true Christ of Lord Christ Jesus"). ${ }^{20}$ Chiara Matraini tells Giulio de' Medici that, in return for presenting to him her version of Isocrates's address to his pupil Demonicus on the conduct of young men, she desires "la sola gratitudine del bellissimo animo suo" ("only the gratitude of your most beautiful spirit"). ${ }^{21}$

\footnotetext{
${ }^{18}$ La geneologia de gli dei de' gentili, fol. *2 ${ }^{\mathrm{v}}$. On Betussi's translation, see Lucia Nadin Bassani, Il poligrafo veneto Giuseppe Betussi (Padua: Antenore, 1992), pp. 42-43, 56-65. Some of its errors are noted in Giovanni Boccaccio, Genealogie deorum gentilium libri, ed. Vincenzo Romano (2 vols., Bari: Laterza, 1951), II. 820822.

${ }^{19}$ Marcel Mauss, The Gift: The Form and Reason for Exchange in Archaic Societies, trans. W. D. Halls (London: Routledge, 2002), p. 4.

${ }^{20}$ Il Nuovo Testamento di Christo Giesù Signore, et Salvatore nostro, di greco novamente tradotto in lingua toscana, per Antonio Brucioli (Venice: Lucantonio Giunta, 1532), fol. $++4^{\mathrm{v}}$.

${ }^{21}$ Oratione d'Isocrate a Demonico . . . tradotta da Madonna Chiara Matraini (Florence: Lorenzo Torrentino, 1556), fol. $\mathrm{A} 4^{\mathrm{v}}$.
} 
At most, translators might work into their letters an allusion to the dedicatee's generous nature, or to the benefits they have received from her or him in the past, thus alluding to a future gift only as a possibility, and only obliquely. For instance, Betussi assures Collaltino that nobody should think that, because of the count's reputation for generosity, he has worked on Boccaccio's Geneologia in the hope of seeking a reward; he has already experienced the count's generosity without doing anything to deserve it. ${ }^{22}$ Setting themselves above the expectation of a gift allowed translators in early modern Italy to present themselves as gentlemen — working voluntarily and under obligation to no one.

\section{Pointing out the Topicality of the Translated Text}

As well as shaping the translator's self-image, letters of dedication could make the target text relevant to matters of contemporary public interest. This extratextual process of assimilation was akin to the domestication of the target text itself, described by Lawrence Venuti as "an ethnocentric reduction of the foreign text to receiving cultural values, bringing the author back home". ${ }^{23}$ Guarino of Verona wrote two letters when he dedicated his Latin translation of Strabo's Geography. The first, dating from 1455 and addressed to Pope Nicholas V, relates the study of geography to the power of the pope: Christ told St. Peter that whatever he bound on earth would be bound in heaven (Matt. 16:19), and Nicholas V had commanded Guarino

\footnotetext{
${ }^{22}$ La geneologia de gli dei de' gentili, fol. $* 3^{\mathrm{r}}$. Other examples are Domenichi's tribute to the generosity of Leo $\mathrm{X}$ and François I in his dedication of Giovio, Dell'historie del suo tempo to Catherine de' Medici (fol. [fleuron] $2^{\mathrm{r}}$ ), and Varchi's expression of gratitude to her for benefits already received in Seneca, De benefizii, as well as the link he makes between the work's subject and the "liberalità" of Catherine and Duke Cosimo (fols. $\left.\mathrm{a} 2^{\mathrm{v}}-\mathrm{a} 3^{\mathrm{r}}\right)$.

${ }^{23}$ Lawrence Venuti, The Translator's Invisibility: A History of Translation (London and New York: Routledge, 1995), p. 15.
} 
to make this translation so as to extend our common knowledge of all lands and seas. ${ }^{24}$ The second letter, addressed to Iacopo Antonio Marcello three years later, describes at length the role of the Marcello family in the history of Venice, especially in the wars with Milan waged since 1438. The selfless virtues of Iacopo Antonio himself are compared with those of heroes of republican Rome: "Illud tua de continentia integritate innocentia occurrit saeculis omnibus celebrandum, Fabriciis Curiis Aemiliis Catonibus sane conferendum" ("Your moderation, integrity, blamelessness are to be celebrated in all ages, and are truly comparable to the Fabricii, Curii, Aemilii and Catos"). ${ }^{25}$ Guarino continues: "Strabo e Graecia in Italiam nuper adventans triumphaturus est tam illustrem nactus hospitem ... et proinde tibi eas gratias habiturum, ut quocunque iter et cursus aget, nomen tuum disseminet" ("Strabo is about to celebrate a triumph after recently arriving from Greece to Italy and gaining such an illustrious host ... and he will be so grateful to you as to spread your name wherever his journey takes him"). ${ }^{26}$ In another dedication that uses the trope of the author being brought to present-day Italy, in a translatio that benefits all, Boiardo expects that Herodotus, in vernacular guise, will be welcomed like any other distinguished foreign visitor into the court of Duke Ercole I of Ferrara:

Nè dubito che honoratamente sarà ricevuta la honerabile antiquità di questo auttore, nella vostra corte, la quale di tutte le virtù, da molte parte bandite, è fatta recettaculo et unico ridotto. E come spesse volte molti principi forestieri ho veduti in quella

\footnotetext{
${ }^{24}$ Remigio Sabbadini (ed.), Epistolario di Guarino Veronese, (3 vols., Venice: R. Deputazione Veneta di Storia Patria, 1915-1919), II. 627-629: p. 629.

${ }^{25}$ Epistolario di Guarino Veronese, p. 633.

${ }^{26}$ Epistolario di Guarino Veronese, p. 634.
} 
ricettare, e di Inghilterra et di Spagna et di Ungaria et dalle altre estremità del mondo, così gli adirizzo questo vecchio greco di sua patria cacciato.

(Nor do I doubt that the honourable ancientness of this author will be received with honour in your court, which has been made a place of refuge and only retreat of all the virtues, banished on many sides. And just as I have often seen many foreign princes received in it, from England, Spain, Hungary and the other ends of the earth, so I send you this old Greek driven from his own land.) ${ }^{27}$

Guarino's dedication to Marcello is one of a number that are addressed to military commanders and connect classical history with contemporary warfare. The Florentine Alessandro Braccesi chose two captains as recipients of his vernacularisations of the Roman histories of Appian of Alexandria, in which Braccesi worked from the Latin translation by Pier Candido Decembrio. He sent one section of the work, Bellum Carthaginense, Syrum, Particum, et Mithridaticum in vulgari sermone (Rome: Eucario Silber, 1502), to Giovampaolo Orsini, writing of Orsini's own skill in warfare (fol. $\left.\pi 2^{\mathrm{v}}\right)$. [strongly suggest that all details of this reference be given in full in a footnote here] He sent another part, Delle guerre civili de’ Romani (Florence: heirs of Filippo Giunta, 1519), to Gentile Virginio Orsini, captain of the army of King Ferdinand of Naples, praising Orsini's "memorandi fatti nella militare disciplina" (fol. a3 ${ }^{\text {r; }}$ "memorable military deeds") and honourable conduct, and comparing him to Horatius Cocles holding the bridge against Lars Porsena (fol. a ${ }^{\mathrm{r}-\mathrm{v}}$ ).

\footnotetext{
${ }^{27}$ Herodotus, Delle guerre de' Greci et de’ Persi (Venice: Giovanni Antonio Nicolini da Sabbio for Melchior Sessa, 1533), fol. $+8^{\mathrm{v}}$. On this, see Dennis Looney, 'Herodotus and Narrative Art in Renaissance Ferrara: The Translation of Matteo Maria Boiardo', in Brill's Companion to the Reception of Herodotus in Antiquity and Beyond, ed. Jessica Priestley and Vasiliki Zali (Leiden: Brill, 2016), pp. 232-253.
} 
Even a text as remote from contemporary concerns as the comedies of Terence might be brought into the orbit of politics and warfare. In Giustiniani's version of the Andria and Eunuchus (1544), Torresani's dedication to Grolier, mentioned earlier, is preceded by a letter from Giustiniani to Georges d'Armagnac, Bishop of Rodez and French ambassador to Venice, in which the story of the translation becomes bound up with an account of the difficulties facing François I in Italy. ${ }^{28}$ Giustiniani writes:

[S]pero che, sì come la Comedia dopò la commotione suole havere felice fine: così questi movimenti, tanto minaccievoli in vista, et tanto feri, con lo aiuto di Dio, et con la virtù di FRANCIA, mutandosi in lieta catastrophe, dove il principio fu turbolento, et concitato: il fine serà tranquillo, et allegro.

(I hope that, just as comedy has a traditional happy ending after the confusion, so these upheavals, so threatening to see and so fierce, will turn into a glad denouement with the help of God and the virtue of France; where the beginning was turbulent and disturbed, the ending will be calm and cheerful. $)^{29}$

But there was to be no happy ending for the French in Italy.

In another case, a defence of vernacular translation in general takes on a more controversial tone when it uses as its starting-point the question of the translation of the Bible - even though this is not directly relevant to the work in question, Bernardino

\footnotetext{
${ }^{28}$ For the letter from Giustiniani to Georges d'Armagnac, see L'Andria, et l'Eunucho di Terentio, fols. $* 2^{\mathrm{r}}-* 4^{\mathrm{v}}$. Giustiniani must have sent a manuscript copy of the translation to d'Armagnac several years earlier, since in the dedicatory letter of Cicero, Philippica seconda . . . tradotta in volgare per m. Giovanni Giustiniano (Venice: Venturino Ruffinelli, 1538) he mentions that it had met with the bishop's approval.

${ }^{29}$ L'Andria, et l'Eunucho di Terentio, fol. $* 4^{\mathrm{r}-\mathrm{v}}$.
} 
Crisolfo's translation of Isocrates's address to Demonicus. ${ }^{30}$ Crisolfo's impassioned letter of dedication contains outspoken passages such as this:

Io non trovo tante laudi, con le quali inalzar possa quelli, che traducendo libri, o greci o latini, cercano arrecare utilitate a molti; e per contrario non trovo tanti vitupperi, de' quanti ne sono degni quelli, li quali tanto buona operatione sogliono biasmare, la quale, quanto più levarla via s'affaticano, tanto più di giorno in giorno cresce. Et di questa oppenione furno prima alcuni frati predicatori, li quali in su li pergoli de villanie caricorno quelli, ch'el Testamento Novo in lingua italiana tradussero; dicendo che sono stati cagione, che loro non sieno più tenuti nelle sacre letere così sapienti, come prima erano.

(I cannot find praise enough to exalt those who, in translating Greek or Latin books, seek to be useful to many; and on the other hand I cannot find as much vituperation as is deserved by those who are accustomed to censure such a good undertaking, which grows all the more daily as they seek to extirpate it. And this view was held firstly by some Dominicans who from their pulpits heaped insults on those who translated the

\footnotetext{
${ }^{30}$ La prima oratione d'Isocrate a Demonico, tradotta dal greco idioma nel Italico (Venice: [Comin da Trino for] Stefano Alessi and Giovanni Battista Bertacagno, 1548), fols. $a 2^{\mathrm{r}}-\mathrm{a} 4^{\mathrm{r}}$. Crisolfo, from Schio, was the son of Giovanni Antonio Crisolfo, to whom he dedicated his Latin translation of the Tabula Cebetis (Venice: [Bartolomeo Imperatore], 1549). To Marzia Crisogono he also dedicated his translation of Marko Marulić, Dialogo . . . delle eccellenti virtù, et maravigliosi fatti di Hercole (Venice: [Niccolò Bascarini for] Stefano Alessi and Giovanni Battista Bertacagno, 1549). On the printers of these editions, see Dennis E. Rhodes, Silent Printers: Anonymous Printing at Venice in the Sixteenth Century (London: British Library, 1995), pp. 135 and 169.
} 
New Testament into Italian, saying that they were the reason that the Dominicans were no longer considered as wise in the holy scriptures as before. $)^{31}$

This letter, addressed to Marzia Crisogono of Zara, was printed in 1548, just two years after members of the Council of Trent had held a heated debate on the question of whether the laity should have free access to the Scriptures in the vernacular. When Crisolfo was writing, the matter was still unresolved, but in 1559 all vernacular translations of the Bible were placed on the Index of Prohibited Books of Pope Paul IV. ${ }^{32}$

Other acts of dedication have a topical political dimension that is not spelled out but that emerges from the context of presentation. Cristoforo Landino could not present his translation of Pliny's Naturalis historia (Venice: Nicolas Jenson, 1476) to Lorenzo de' Medici or his brother Giuliano, since this could be seen as implying that they preferred a translation. Instead Landino was able to offer his version to Ferdinand I, king of Naples, as a demonstration of the superiority of Tuscan over other dialects of Italy, and as a gesture of friendship towards a ruler who was at this point a powerful ally of Florence. Carlo Dionisotti comments that, in these circumstances, the homage had "un significato politico prima ancora che letterario" ("a political significance even before a literary one"). ${ }^{33}$ In 1535 , Antonio Minturno made a politically loaded dedication when he sent a manuscript of his Latin version of a work by Plutarch to the Spanish statesman Miguel Mai. The work itself, the Septem sapientium convivium (The Dinner of the Seven Wise Men), includes discussion of the

\footnotetext{
${ }^{31}$ La prima oratione d'Isocrate a Demonico, fol. $\mathrm{a}^{\mathrm{r}}{ }^{\mathrm{r}-\mathrm{v}}$.

${ }^{32}$ Gigliola Fragnito, La Bibbia al rogo: La censura ecclesiastica e i volgarizzamenti della Scrittura (14711605) (Bologna: Il Mulino, 1997), pp. 75-95. On the Dominicans' anxiety over the diffusion of Biblical translations (but not over such translations per se), see the same volume, at pp. 57-60.

${ }^{33}$ Carlo Dionisotti, 'Tradizione classica e volgarizzamenti', in Geografia e storia della letteratura italiana (Turin: Einaudi, 1967), pp. 103-144, at p. 124.
} 
government of states, but here the target text acquired an added political significance: firstly because Mai was a leading figure in the service of Emperor Charles V, as a former imperial ambassador to Rome in 1528-33 and now vice chancellor of Aragón; secondly because the translation was sent together with a Latin poem by Minturno, entitled Mercurius, that celebrated the ruling house of Spain, and in which the leading character is a representation of Mai. $^{34}$

In 1547 Antonio Brucioli wrote a letter dedicating Aristotle, Gli otto libri della republica, che chiamono Politica, nuovamente tradotti di greco in vulgare italiano per Antonio Brucioli (Venice: Alessandro Brucioli and brothers, 1547), to the condottiere Piero Strozzi. Brucioli's choice had a subtext intended to seem extremely provocative. He had fled Florence as an opponent of the Medici-dominated regime in 1522, but later acted as an informer on behalf of the Medici in Venice. Piero Strozzi was the son of Filippo, who had been a leader of the republican Florentine rebels and had died while imprisoned in Florence in 1538. Brucioli's letter passes over Strozzi's involvement in campaigns against the Medici and their allies, but describes in detail his subsequent military career in France. ${ }^{35}$ It was probably in deliberate opposition to Brucioli's translation that another version of Aristotle's

\footnotetext{
${ }^{34}$ Madrid, Biblioteca Nacional, MS 18659, fasc. 28. See Stefano Carrai, 'Minturno traduttore di Plutarco in un manoscritto della Nazionale di Madrid', Italia medioevale e umanistica, 37 (1994), pp. 233-239. On Mai, see Michael J. Levin, Agents of Empire: Spanish Ambassadors in Sixteenth-Century Italy (Ithaca NY: Cornell University Press, 2005), pp. 45-53; Joan Bellsolell Martínez, 'Miguel Mai y Antonio Sebastiano Minturno en la corte de Carlos V', Studia aurea, 4 (2010), pp. 139-178.

${ }^{35}$ See Giorgio Spini, 'Bibliografia delle opere di Antonio Brucioli', La Bibliofilia 42 (1940), pp. 129-180, at p. 165. On Brucioli as translator, see Outi Merisalo, 'Translating the Classics into the Vernacular in SixteenthCentury Italy', Renaissance Studies, 29 (2015), pp. 55-77, at pp. 56-63. On Piero Strozzi’s career, see Stefano Dall'Aglio, The Duke's Assassin: Exile and Death of Lorenzino de' Medici, trans. Donald Weinstein (New Haven: Yale University Press, 2015).
} 
Politics, made by the Florentine Bernardo Segni, was conceived in the same year (1547), and appeared in Florence in 1549 (printed by Lorenzo Torrentino) under a title, Trattato dei governi, that avoided the term repubblica. ${ }^{36}$ This is another case of multiple translation, or more specifically an "active retranslation" in Anthony Pym's classification, since it shares the same cultural context. ${ }^{37}$ Segni's dedicatee was Duke Cosimo himself, and his letter of presentation included a staunch defence of the absolute regime that the Medici had established in the Florence in 1532. Segni points out to Cosimo that, with the help of Aristotle's work,

oltre a molte cose, che gli huomini dei tempi nostri intendono a rovescio, si potrà egli anchora far' lor' manifesto uno errore, il quale è in molti invechiato, et tale è, che e' si stimano la libertà non potere essere, se non dove i Popoli hanno in mano il governo (fol. $\left.\mathrm{A} 4^{\mathrm{r}}\right)$.

(apart from many things that our contemporaries misunderstand, it will also be possible to clarify for them an error ingrained in many, that they believe liberty can exist only where the people control government).

The best form of government is in fact to have a good single ruler, Segni argues, and this is the regime that Florence has adopted by choosing Cosimo (fol. A4 ${ }^{\mathrm{v}}$ ), who has saved his

\footnotetext{
${ }^{36}$ On the preparation of Segni's version, see Simone Bionda, 'La copia di tipografia del Trattato dei Governi di Bernardo Segni: Breve incursione nel laboratorio del volgarizzatore di Aristotele', Rinascimento 42 (2002), pp. 409-442. A Venetian edition was printed in 1551 by Bartolomeo and Francesco Imperatore, and Torrentino produced a second issue of his own edition in 1559.

${ }^{37}$ Anthony Pym, Method in Translation History (London: Routledge, 1998), 82-83.
} 
fatherland and restored it to life (fol. $\mathrm{B} 1^{\mathrm{v}}$ ). It has been suggested, however, that Segni, too, was masking his personal opinions, which were critical of the duke's regime. ${ }^{38}$

Yet another means of making the target text germane to the contemporary context was for the dedicator to portray the personal qualities of the dedicatee as living exemplifications of the teachings of the source text. Sebastiano Manilio tells Ludovico Sforza in 1494 that, if the duke deigns to read Seneca's Pistole, "sembianza di tutte le Virtù che in te riluceno agevolmente troverai" ("you will easily find in them a reflection of all the virtues that shine in you"): prudence, magnanimity, continence, and justice. ${ }^{39}$ Iacopo Nardi, translator of Livy, assures Alfonso d'Avalos, marchese del Vasto, in 1540 that, if he had been capable, he would have written of the deeds of this condottiere rather than of ancient times. Yet he wants to publish his translation under Alfonso's name so that the marquis will receive honour from it:

Imperò che il prudente lettore, era per trovare leggendo, infinite virtuose attioni, tanto civili, quanto militari: dalla contemplatione delle quali, rivolgendo la mente alla eccellentia vostra riconoscerebbe in quella, come in una viva imagine, rinovati mille rari essempii di quell'antico valore.

(Because the prudent reader would find in reading it infinite virtuous actions, both civil and military, and in considering these and turning his mind to you, he would recognise in you, as in a living image, a thousand rare examples of that ancient valour brought back to life.)

\footnotetext{
${ }^{38}$ David A. Lines, 'Ethics, Politics and History in Bernardo Segni (1504-1558): Machiavellianism and AntiMedicean Sentiment', in Christoph Strosetzki (ed.), Ethik und Politik des Aristoteles in der Frühen Neuzeit (Hamburg: Meiner, 2016), pp. 45-68.

${ }^{39}$ Pistole del moralissimo Seneca, fol. $2 \pi 2^{\mathrm{r}}$.
} 
Alfonso, of course, has no need of the translator's labour, but Nardi hopes he will still welcome and approve it. ${ }^{40}$ Similarly, Remigio Nannini is certain that yet another condottiere, Giovan Luigi Vitelli, known as Chiappino, has always exemplified the ways of dealing with the hazards of fortune that Petrarch outlines in his De remediis utriusque fortunae. ${ }^{41}$ Chiara Matraini sends her version of the Oratione d'Isocrate a Demonico to Giulio de' Medici (illegitimate son of Duke Alessandro) since the most precious gift she can offer is "quella vera norma di bellissimo, e santissimo vivere, che la fa come una idea del mondo de' più purgati ingegni maravigliosamente guardare" ("that true norm of the most fair and holy life that makes you regarded with amazement as an image of the world of the purest spirits"). ${ }^{42}$ Having thus stretched flattery to its limits, Matraini underlines in an accompanying sonnet that Giulio himself has absolutely no need of these teachings. ${ }^{43}$

Occasionally, however, the translator felt that the dedicatee might have something to learn from the text. Alfonso Ulloa chose Duke Alfonso II d'Este to receive his version of $E l$ concejo y consejeros del príncipe by the Spanish humanist Fadrique Furió Ceriol, "accioché mediante i savi concili di quello sappia governarsi con prudenza verso i sudditi, et verso gli

\footnotetext{
${ }^{40}$ Le deche delle historie Romane di Tito Livio padovano, tradotte nuovamente nella lingua toscana, da Iacopo Nardi cittadino fiorentino (Venice: heirs of Lucantonio Giunta, 1540), fol. $+2^{\mathrm{r}}$. “Antico valore” alludes to Petrarca, Canzoniere, 128.95.

${ }^{41}$ Opera di m. Francesco Petrarca, De rimedi de l'una et l'altra fortuna, ad Azone, tradotta per Remigio Fiorentino (Venice: Gabriele Giolito, 1549), fol. A4 ${ }^{\mathrm{r}}$.

${ }^{42}$ Oratione d'Isocrate a Demonico, fols. A $3^{\mathrm{v}}-\mathrm{A} 4^{\mathrm{r}}$.

${ }^{43}$ Oratione d'Isocrate a Demonico, fol. A4 ${ }^{\mathrm{v}}$. This edition (Florence: Lorenzo Torrentino, 1556) was arranged by Domenichi, according to a second letter addressed to Matraini by the printer, dated 9 February 1556 (Matraini's letter is undated). In April 1556 Giulio de' Medici was appointed as the Florentine commissario in Lucignano: see Daniela Stiaffini, Giulio di Alessandro: Un Medici a Pisa (Pisa: ETS, 2015), pp. 42-45.
} 
amici et nimici suoi" ("so that, through his wise counsel, you may know how to behave prudently towards your subjects, and towards your friends and enemies"), for the work contains much advice useful for good government. ${ }^{44}$ Remigio Nannini suggests in 1568 to the young Pietro de' Medici, then aged fourteen, that Iacopo Baroncelli's version of Pontano's De oboedientia will provide a useful lesson for a person destined to rule, since someone who knows how to obey also knows how to command. ${ }^{45}$ Unfortunately, as Salvatore Bongi pointed out, Pietro's later life shows how little benefit he derived from the work. ${ }^{46}$

How can the foregoing evidence of the social publication of early modern translations in Italy shed light on three themes that underpin this volume: the self-presentation of translators, including the establishment of their trustworthiness; their roles as cultural agents and mediators; and their use of the new medium of print? The above examples show these translators using the letter of dedication as a means of associating themselves in the eyes of the reading public with a person who was almost always of high status, even if it was just the opening gambit in a social relationship that was destined to remain merely desired or at best distant. The relationship might also act as a shield for the translator's work, while generating trust in it through association with the prestige of the dedicatee. This protection was important whether translators presented their activities as entirely justified, or whether, in giving some account of their work, they admitted to anxieties about the inadequacies of their

\footnotetext{
${ }^{44}$ Il concilio, et consiglieri del principe (Venice: Francesco Bindoni, 1560), fol. a2 ${ }^{\mathrm{r}-\mathrm{v}}$.

${ }^{45}$ Giovanni Pontano, Trattato dell'obedienza ... tradotto da m. Iacopo Baroncelli (Venice: Gabriele Giolito, 1568), fols. $* 2^{\mathrm{r}}-* 3^{\mathrm{v}}$.

${ }^{46}$ Salvatore Bongi, Annali di Gabriel Giolito de' Ferrari da Trino di Monferrato stampatore in Venezia (2 vols., Rome: Ministero della Pubblica Istruzione, 1890-1897), II. 267-268.
} 
language in comparison with the source language. The act of dedication may have allowed translators to show modesty, by giving credit to the dedicatee for encouraging the task in the first place, and also to adopt a pose of selflessness, by respecting the decorum of gift-giving and denying any expectation of material reward.

With reference to the role of translators as agents within the politics and culture of their own times, we have seen that their letters of dedication could give the target text an ideological relevance to events, controversies and prominent personalities of the age in which it was published. As such, the letters encouraged a contemporary readership to approach the new text from a particular perspective.

In manuscript culture a translation might not have traveled much further than its dedicatee, as was probably the case with Minturno's version of Plutarch. In printed editions, the letter of dedication became a much more powerful tool because, while addressed to an individual, it was intended to be absorbed also by a much wider reading public. It thus took on a more complex and more significant role as an exegetic framing device. While the introductory letter continued to be the expression of a one-to-one relationship between translator and dedicatee, thenceforth hundreds of other readers would approach the target text influenced by the context that this letter created.

A few source texts, such as works by classical Latin poets, were modernised and "domesticated" by early modern Italian translators when, within the text itself, they added references to the contemporary world, occasionally substituting them for references to the world of the original author. ${ }^{47}$ Another process of modernisation is seen, and much more regularly, in the uses that translators made of social publication. For them, dedicatory letters

\footnotetext{
${ }^{47}$ For examples of such interpolations, see Bodo Guthmüller, 'Letteratura nazionale e traduzione dei classici nel Cinquecento', Lettere italiane, 45 (1993), pp. 501-518: pp. 507-508, and Merisalo, 'Translating the Classics', pp. 67-68.
} 
became a means of integrating translated texts within the present, and hence a means of enhancing their power to shape the culture of their own times. 


\title{
CHAPTER 2
}

\section{Monkey Business: Imitatio and Translators' Visibility in Renaissance Europe ${ }^{1}$}

\author{
Andrea Rizzi
}

In the first folio of an Italian vernacular version of Petrarch's De viris illustribus, two portraits stand out. Positioned centrally in the margin on opposite sides of the title page, each figure is oriented to face the other. The portrait in the narrower, left margin is of a young male, bare chested and unshaven. His portrait is supported by a monkey on all fours. ${ }^{2}$ The figure on the opposite side of the folio is Petrarch, the Latin author of the text. (Figure 1) ${ }^{3}$

\footnotetext{
${ }^{1}$ I wish to thank Cynthia Troup, Gerardo de Simone, Giovanni Fara, Gabriele Mino, Timothy McCall, Alina Payne, Victor Stoichita, and the 2016-2017 Villa I Tatti Harvard Center for Italian Renaissance Studies fellows for their invaluable suggestions while drafting of this work. I am also grateful to Anne E. B. Coldiron for sharing her most recent work on the visibility of Renaissance English translators and the monkey in William Caxton's woodcut.

${ }^{2}$ Henceforth throughout this chapter, the words "monkey" and "ape" are used interchangeably. Pre-modern scholars did not know apes (gorillas, chimpanzee, orangutans), and thus used the nouns simia or simius to refer to the many kinds of monkeys that had been discussed since antiquity. See Kenneth Gouwens, 'Human Exceptionalism', in John Jeffries Martin (ed.), The Renaissance World (New York: Routledge, 2007), pp. 415434, at p. 416.

${ }^{3}$ Madrid, Biblioteca Nacional de España, res. 214, fol. $1^{\mathrm{r}}$ is illuminated by Matteo di Giovanni, or Maestro di Fiesole (also known as Maestro della Farsaglia, a name coined by Annarosa Garzelli). This miniaturist worked for the Medici family, in the Badia Fiesolana, and for several other patrons, including Íñigo Lopez de Mendoza, for whom this manuscript was produced. The Maestro della Farsaglia nickname refers to the beautifully illuminated version of Lucan's Pharsalia held in Milan, Trivulziana Library, ms. 692. The coat of arms at the bottom of fol. $1^{\mathrm{r}}$ is of the Marquis of Santillana. In the four corners of folio one there is the emblem of Íñigo Lopez de Mendoza, Marquis of Santillana (1398-1458): a warrior helmet. There is also a portrait of the
} 


\section{[PLACE FIG. 1 HERE]}

[CAPTION FOR FIG. 1: Figure 1: Biblioteca Nacional de España, Res. 214, fol. $1^{\mathrm{r}}$. Reproduced by permission of the National Library of Spain]

Portraits of facing figures at the two extremes of the centre page feature in several other title pages of Italian books from the same period, and, in broadest terms, they serve to underscore the relationship between author and translator, or author and patron. ${ }^{4}$ The meaning of the young male's portrait held up by a monkey on the left side of the folio is elusive. The youth does not resemble any of the putti or angels that feature in the work of Matteo di Giovanni, the artist of this miniature. The portrait also differs considerably from comparable decorations by miniaturists from the same period and region: Filippo Maria Torelli; Ser Ricciardo di Nanni; the so-called Miniaturist of the Marquis of Santillana, and the so-called Master of the Neapolitan Virgil. ${ }^{5}$ There are several contemporary examples of author

armoured leader on a horseback in the illuminated initial. For a detailed description of this manuscript see Milagros Villar, Códices Petrarquescos en España (Padua: Antenore, 1995), pp. 203-204. On the Maestro della Farsalia see Villar, Códices, 202, and Annarosa Garzelli, ed., Miniatura fiorentina del primo rinascimento (1440-1525). Un primo censimento (2 vols., Florence: La Nuova Italia, 1985), I. 36-37. On Santillana’s life and literary work see Rafael Lapesa, La obra literaria del Marques de Santillana (Madrid: Insula, 1957).

${ }^{4}$ See for instance Venice, Biblioteca della Fondazione Giorgio Cini, ms. 2518/7, fol. $11^{\mathrm{r}}$ where the portrait of the author, Petrarch, in the title letter, is directly opposite the portrait of the patron. See also Florence, Biblioteca Riccardiana, 712, fol. $1^{\mathrm{r}}$. In this decoration, the portrait of Achilles (on the right) is bigger than a young man portrayed opposite. This young figure is most likely a member of the Medici family. A description of this Riccardiana manuscript and image is in Riccardo Gennaioli (ed.), Pregio e bellezza. Cammei e intagli dei Medici (Livorno: Sillabe, 2010), p. 117.

\footnotetext{
${ }^{5}$ The only two similarities I have found are: a young man's portrait in the title letter of Florence, Biblioteca Mediceo Laurenziana, Plut. 48.8, fol. $2^{\mathrm{r}}$. This miniature is attributed to Ricciardo di Nanni and is dated $c a .1459$. In this case, the young man decorates the title letter. For a description of the title page in Florence, Biblioteca
} 
portraits counterposed with portraits of other authors or translators. ${ }^{6}$ The young male in figure 1 is unlikely to be a realistic depiction of an author, patron, or translator. Yet this youthful figure meeting Petrarch's gaze is tantalising; its prominent position on the title page encourages further investigation into the representation of monkeys, authors, and translators in Renaissance scribal and print cultures. Why is this young man facing the fourteenthcentury author? Why is his portrait held up by a monkey?

This chapter offers a first answer to these questions by examining manuscript and printed images in which translators, patrons, and monkeys feature on the same page. It

Mediceo Laurenziana, Plut. 48.8 , fol. $2^{\mathrm{r}}$ see Pregio e bellezza, p. 101. Another portrait of a young man that probably influenced Giovanni di Matteo is in Biblioteca Mediceo Laurenziana, Plut. 66.8, fol. $2^{\mathrm{r}}$. I have also examined the following title pages from manuscripts illuminated by Maestro della Farsaglia: Madrid, Biblioteca Nacional de España, res. 212, fol. $1^{\mathrm{r}}$. This manuscript contains Giovanni da San Miniato's vernacular translation of Petrarch's De remediis utriusque fortunae. This codex was also commissioned by the Marquis of Santillana. The manuscript is described by Villar, Códices Petrarquescos en España, pp. 201-202; Paris, Bibliothèque de 1’Arsenal, 629, fol.1 ${ }^{\mathrm{r}}$; London, British Library, Add. 14783, fol.1 ${ }^{\mathrm{r}}$; Milan, Biblioteca Trivulziana, 692, fol. 1' Florence, Biblioteca Mediceo Laurenziana, Plut. 19.9, Fiesol. 19, and Fiesol. 20. I have also examined illuminations of title pages by artists who influenced or have been influenced by the Maestro della Farsalia: Filippo Maria Torelli; Ser Ricciardo di Nanni; the so-called Miniaturist of the Marquis of Santillana, and the socalled Master of the Neapolitan Virgil. See Miniatura fiorentina, I. 33-66, and the reproductions of the title pages in II. 39-90. See also Donatella Coppini and Mariangela Regoliosi (eds.), Gli umanisti e Agostino. Codici in mostra (Florence: Edizioni Polistampa, 2001), pp. 174-187, pp. 299-300, and Sebastiano Gentile (ed.), Umanesimo e Padri della Chiesa. Manoscritti e incunaboli di testi patristici da Francesco Petrarca al primo Cinquecento (Milan: Rose, 1997), p. 329.

${ }^{6}$ See Venice, Fondazione Cini, 2518/7, containing a 1460s copy of Petrarch's Rerum vulgarium fragmenta, Triumphi, and Nota de Laura, and Leonardo Bruni's Vita del Petrarca and Notizia del Boccaccio. On fol. $11^{\mathrm{r}}$ there is a portrait of young Petrarch facing a portrait of Bruni. The miniaturist is Mariano del Buono. See Massimo Medica and Federica Toniolo (eds.), Le miniature della Fondazione Cini. Pagine, ritagli, manoscritti, (Milan: Silvana, 2016), pp. 205-209. 
explores how these images might have been read and understood by Renaissance readers and patrons in the context of authorial self-presentation and self-awareness. I argue that in fifteenth- and sixteenth-century Europe, authors, translators, and printers depicted monkeys in their manuscript or printed self-portraits to alert readers and patrons to their self-aware role as trustworthy imitators of ancient or medieval authors, and reliable cultural agents for their audiences. The presence of monkeys beside translators in Renaissance manuscript and printed texts sheds light on the ethos of Renaissance translators. The compresence of monkeys, dogs, and translators in dedication copies of translations underpinned the translators" "strategy of argumentation ..., a way of recommending oneself for employment not exclusively on the basis of qualifications or birth, but on the basis of personal character and worth". ${ }^{7}$ Representations of monkeys and, in some cases, dogs helped the reader understand the nature of the translation and the skills of the translators.

In one sense, this chapter is a response to a recent call to study and revalue the history of translators in which visibility rather invisibility is the translators' and printers' modus operandi. ${ }^{8}$ In contemporary Western cultures translators are mostly invisible because they are "required to efface [their] second-order status with the effect of transparency, producing the

\footnotetext{
${ }^{7}$ John F. Tinkler, 'Renaissance Humanism and the Genera Eloquentiae', Rhetorica: A Journal of the History of Rhetoric, 5 (1987): pp. 279-309, at p. 298. In ancient Greek and Roman rhetoric, ethos refers to the orator's character as it is self-constructed in order to persuade the audience. Recent studies have shown how slippery the term "ethos" can be: for Norbert Elias it refers to a social group's behaviour; for Pierre Bourdieu it designates a series of dispositions or practical principles. See Dominique Maingueneau, 'Le recours à l'ethos dans l'analyse du discours littéraire', Postures d'Auteurs: du Moyen Âge à la modernité. Fabula (online), 2013:

http://www.fabula.org/colloques/document2424.php. See Marie-Alice Belle's chapter in the present volume for a more exhaustive discussion.

${ }^{8}$ Anne E. B. Coldiron, 'Visibility Now: Historicizing Foreign Presences in Translation', Translation Studies, 5
} (2012), pp. 189-200. 
illusion of authorial presence whereby the translated text can be taken as the original". ${ }^{9}$ But such invisibility was not the norm in late medieval and Renaissance Europe; scholarship has demonstrated that the Renaissance printing industry gave much visibility to the identity, role, and authority of translators. "Visibility" refers here to statements and other indications left by Renaissance translators, printers, or patrons in the translated text or in the texts accompanying the translation such as frontispiece, letters of dedication, prefaces (henceforth “paratext”). These marks were meant to guide readers' understanding of the translation, the role of the translator, and the collaboration underpinning the production of the translated text. Asserting visibility was also a key strategy in the complex economy of dedication in Renaissance Europe's production of manuscript and printed texts. ${ }^{11}$ The paratext offered

\footnotetext{
${ }^{9}$ Lawrence Venuti, The Translator's Invisibility. A History of Translation (London: Routledge, 1995/2008), 6.

${ }^{10}$ Anne E. B. Coldiron, Printers Without Borders. Translation and Textuality in the Renaissance (Cambridge: Cambridge University Press: 2015); Helen Smith and Louise Wilson, Renaissance Paratexts (Cambridge and New York: Cambridge University Press, 2011); Susanna de Beer, The Poetics of Patronage: Poetry as SelfAdvancement in Giannantonio Campano (Turnout: Brepols, 2013); José Marìa Pérez Férnandez and Edward Wilson-Lee (eds.), Translation and the Book Trade in Early Modern Europe (Cambridge: Cambridge University Press, 2014), and Andrea Rizzi, Vernacular Translators in Quattrocento Italy: Scribal Culture, Authority, and Agency (Turnout: Brepols, 2017).

${ }^{11}$ An extensive bibliography on the economy of dedication and "print authorship" in Renaissance England is given by Marie-Alice Belle in this volume. On paratext see Gérard Genette, Paratexts: Thresholds of Interpretation (Cambridge and New York: Cambridge University Press, 1997); Brian Richardson, Manuscript Culture in Renaissance Italy (Cambridge and New York: Cambridge University Press, 2009), pp. 198-216; Marco Paoli, La Dedica. Storia di una strategia editoriale (Italia, secoli XVI-XIX) (Lucca: Maria Pacini Fazzi, 2009); Smith and Wilson, Renaissance Paratexts; Mariangela Regoliosi, 'Il paratesto dei manoscritti', Paratesto 3 (2004), pp. 9-33. There is a vast literature on patronage. On patronage in Renaissance Italy see Francis W. Kent, Patricia Simons, and John C. Eade (eds.), Patronage, Art, and Society in Renaissance Italy (Canberra and New York: Oxford University Press, 1987); Lauro Martines, Strong Words: Writing and Social Strain in the
} 
readers and patrons "aesthetic resources . . . or even subtle ethical models of encountering alterity". ${ }^{12}$ Visibility therefore represented an opportunity for the Renaissance translator, printer, patron, and reader to share and enjoy foreign literature that was otherwise not easily accessible. At the same time, visibility endowed the translator, printer, and patron with cultural recognition and financial gain. ${ }^{13}$ This chapter illuminates a specific kind of visibility used by the early modern translator: an "artistic visibility", in which the mise en page of courtly monkeys and dogs acts offers visual cues for the reader and patron about the nature of the translation and the skills of the translator.

In this chapter I argue that the presence of monkey and dogs in the images discussed below illuminates the translators' self-aware agency, and the collaborative nature of their

Italian Renaissance (Baltimore: Johns Hopkins University Press, 2003); Dale V. Kent, Cosimo de’ Medici and the Florentine Renaissance: The Patron's Oeuvre (New Haven: Yale University Press, 2000); Jill Burke, Changing Patrons: Social Identity and the Visual Arts in Renaissance Florence (University Park: Pennsylvania State University Press, 2004), and Jonathan Nelson, The Patron's Payoff: Conspicuous Commissions in Italian Renaissance Art (Princeton: Princeton University Press, 2008). More specifically on the mechanics of art patronage see Francis Haskell, Patrons and Painters: A Study in the Relations between Italian Art and Society in the Age of the Baroque (London: Chatto \& Windus, 1963), and Mary Hollingsworth, Patronage in Renaissance Italy: From 1400 to the Early Sixteenth Century (London: John Murray, 1994). A sociological analysis of patronage through a study of Florentine letters of fifteenth-century Italy can be found in Paul D. McLean, The Art of the Network: Strategic Interaction and Patronage in Renaissance Florence (Durham NC: Duke University Press, 2007).

${ }^{12}$ Anne E. B. Coldiron, 'Visibility Now', p. 189.

${ }^{13}$ For cultural and financial capital acquired by translators in fifteenth-century Italy see Andrea Rizzi, Vernacular Translators, chapters 1 and 2. 
work. To this end, I set out a microhistory of translators' visibility by examining the physical, paratextual, and visual features of Renaissance manuscript and printed translations. ${ }^{14}$

\section{Apes and Translators}

Primates have always been perceived as poor imitators of humans. ${ }^{15}$ From this belief there developed, from the sixteenth century onward, the topos of arts as ape of nature-ars simia naturae. ${ }^{16}$ In his Naturalis historia (first century CE), Pliny the Elder describes monkeys as being similar to mankind, and cunning. ${ }^{17}$ Likewise, in his early thirteenth-century treatise $D e$ animalibus, Albertus Magnus describes monkeys and dwarfs as man-like creaturessimilitudines homines. ${ }^{18}$ In the words of the ancient poet Ennius (quoted by Cicero), "how similar is the ape, a most-foul beast, to us". ${ }^{19}$ The Latin word simia itself was believed to be

\footnotetext{
${ }^{14}$ On microhistory and translation history see Sergia Adamo, 'Microhistory in Translation', in George L. Bastin and Paul F. Bandia (eds.), Charting the Future of Translation History (Ottawa: The University of Ottawa Press, 2006), pp. 81-100.

${ }^{15}$ Gouwens, 'Human Exceptionalism', p. 416.

${ }^{16}$ See Horst W. Janson, Apes and Apes Lore in the Middle Ages and the Renaissance (London: Warburg Institute, University of London, 1952), pp. 287-325, and Karl A. E. Enenkel and Paul J. Smith (eds.), Zoology in Early Modern Culture: Intersections of Science, Theology, Philology, and Political and Religious education, (Leiden and Boston: Brill, 2014), pp. 375-376.

${ }^{17}$ See the fifteenth-century translation of Pliny's work by Neapolitan Giovanni Brancati in Marcello Barbato, Il Libro VIII del Plinio Napoletano di Giovanni Brancati (Naples: Liguori, 2001), pp. 88-89. Sarah Blake McHam has recently shown the legacy of Pliny's work in the textual, visual, and scientific cultures of Renaissance Italy in her Pliny and the Artistic Culture of the Italian Renaissance (New Haven: Yale University Press, 2013).

${ }^{18}$ Robin O’Bryan, “Grotesque Bodies, Princely Delight: Dwarfs in Italian Renaissance Court Imagery”, Preternature: Critical and Historical Studies on the Preternatural, 1 (2012), pp. 252-288: p. 275. See also Janson, Apes and Ape Lore, pp. 85-86. I am grateful to Timothy McCall for alerting me to O'Bryan's work. 19 “simia quam similis turpissima bestia nobis": Cicero, De natura deorum, 1.35.97.
} 
etymologically connected with similitudo ("simia quam similis"), underscoring the key perception of monkeys as beastly imitators of humans and a "joke of nature". Monkeys' ability to imitate mankind also made them popular pets in late medieval and Renaissance Europe. They were often used as performing animals, and were trained to imitate human behaviour for entertainment. ${ }^{20}$

The likeness between humans and apes was deeply unsettling for the ancients as well as medieval and Renaissance writers. This understanding of apes inspired numerous visual representations of monkeys acting as men, or being devious or mischievous. In medieval manuscripts, monkeys and other "irreverent" beasts occupy the "cultural space of the [printed or manuscript] margins" and were often used to symbolise vices, such as deceit, fraud, vanity, and promiscuity, among others. ${ }^{21}$

Evidently, imitation was a key source of fascination and amusement for Renaissance audiences. Renaissance scholars and authors understood imitation as a creative process that

\footnotetext{
${ }^{20}$ See for instance the depiction of monkeys in urban settings by Masaccio, Healing of the Cripple and Raising of Tabatha (left view), 1426-1427, fresco, Cappella Brancacci, Santa Maria del Carmine, Florence; Pietro Lorenzetti, Flagellation of Christ (ca. 1320), fresco, Lower Church, San Francesco, Assisi, and Attavante (miniaturist), Missal (late fifteenth century), Lyon, Bibliothèque Municipale, ms. 512, fol. $6^{\mathrm{v}}$. On monkeys as domestic and urban pets in early modern society see Thomas Keith, Man and the Natural World: Changing Attitudes in England, 1500-1800 (Harmondsworth: Penguin, 1984), p. 123; Erica Fudge, Perceiving Animals: Humans and Beasts in Early Modern English Culture (Urbana: University of Illinois Press, 2002), and Erica Fudge, Pets (London: Routledge, 2009). Most recently, see the Renaissance Studies special issue on the animal in Renaissance Italy edited by Sarah Cockram and Stephen Bowd, 31 (2017), pp. 183-318, especially, pp. 277296.

${ }^{21}$ Michael Camille, Image on the Edge: The Margins of Medieval Art (London: Reaktion Books, 1992), p. 9. In some of these representations, monkeys mimic or parody the first sinners, and they signify Adam and Eve's becoming sinful and debased. This tradition will not be discussed in this chapter.
} 
could transform both writer and reader-provided that the imitation was performed by scholars with the appropriate training and skills, who addressed their work to an educated audience. Late medieval and Renaissance authors commonly referred to monkeys either to praise or blame imitators or followers of ancient authorities. Being a close imitator of an influential textual authority such as Cicero was a practice commended by some Renaissance scholars, whereas for others this practice was perceived as too slavish an imitation. The spectrum of possibilities for literary and rhetorical production swung between imitation of eloquent speech as a worthy and civilising process, and the danger of losing one's own voice by following a literary or oratorical model too closely, or poorly. ${ }^{22}$ A fine line separated a "good" imitator who internalised and competed against the model from a "bad" imitator of a commendable model: the latter was known as a "schluraffen", or lazy ape, from Desiderius Erasmus's “ape of Cicero". ${ }^{23}$ Late medieval and Renaissance authors and translators such as Petrarch, Coluccio Salutati, Angelo Poliziano, or Paolo Cortesi variously praised or mocked their peers for imitating ancient literary authorities like monkeys. ${ }^{24}$ The negative connotation

\footnotetext{
${ }^{22}$ Gouwens, 'Human Exceptionalism'; see also Christopher Celenza, 'End Game: Humanist Latin in the Fifteenth Century', in Y. Maes, J. Papy, and W. Verbaal (eds.), Latinitas Perennis II: Appropriation and Latin Literature (Leiden: Brill, 2009), pp. 201-242, and Thomas M. Greene, The Light in Troy: Imitation and Discovery in Renaissance Poetry (New Haven: Yale University Press, 1982), pp. 147-170.

${ }^{23}$ Sebastian Brandt, Narrenschiff (Ship of Fools) (Basel: Johan Bergmann, 1494), p. 108. This detail is from Janson, Apes and Apes Lore, 227 (n. 21).

${ }^{24}$ On Renaissance imitatio and translation see Frederick M. Rener, Interpretatio. Language and Translation from Cicero to Tytler (Amsterdam-Atlanta: Rodopi, 1989), pp. 293-317; Martin M. McLaughlin, Literary Imitation in the Italian Renaissance. The Theory and Practice of Literary Imitation in Italy from Dante to Bembo (Oxford: Clarendon Press, 1995); Rita Copeland, Rhetoric, Hermeneutics and Translation in the Middle Ages: Academic Tradition and Vernacular Texts (Cambridge: Cambridge University Press, 1991), and Peter Mack, A History of Renaissance Rhetoric 1380-1620 (Oxford: Oxford University Press, 2011).
} 
is the one that persisted through centuries, as indicated by twenty-first-century French translator Maurice-Edgar Coindreau (1892-1990):

Firstly, a translator is a person with no rights, only duties. He must show loyalty to the author like a dog, but as a special dog who behaves like a monkey. If I'm not mistaken, Mauriac [French novelist] wrote: “The novelist is God's monkey." Well, the translator is the novelist's monkey. He is obliged to pull the same faces, like it or not. $^{25}$

Coindreau's remark addresses the question of where translation sits in the history of literary imitation. Obviously, translators were and are expected to imitate the author's style and voice. In antiquity, as in the Renaissance, imitation was an essential exercise for the learning of Latin or Greek. Translation was a key pedagogical tool for imitation of an author. Wordfor-word translation, paraphrasing, and the study of grammar were the building blocks of proficiency in the target language. After completing their grammatical training, orators, authors, and translators performed imitatio: this term designates a highly skilled "command of past techniques which possess continuous sanctions and a sensitivity to the unique demands of the present situation". If imitation was a necessary training step towards mastery of a literary language, imitatio was the creative force by which an ancient model was adapted or surpassed by the Renaissance author or translator. ${ }^{26}$

\footnotetext{
${ }^{25}$ This passage is from Coindreau's 'Credo du traducteur' published in L'express 1213 (1974), p. 74. The English translation is from http://culturesconnection.com/20-quotes-about-translation/ (last accessed 10 October 2016).

${ }^{26}$ Green, The Light of Troy, p. 32: the quote is originally in Nancy S. Struever, The Language of History in the Renaissance (Princeton: Princeton University Press, 1970), p. 193.
} 
The examples discussed in this chapter fall into two categories of self-representation used by artists and authors in late medieval Europe: the two categories are "textualised" images and "transposed" images. ${ }^{27}$ The first refers to authors (in the present case translators) depicted within a miniature, and shown engaging in some way with the text they have composed. This is an extremely common feature of medieval and Renaissance manuscripts and occurs frequently in the portraits of Renaissance translators and authors appearing in the title pages or frontispieces of manuscript and printed texts. The second type indicates the insertion of a stand-alone portrait into the text. The portraits discussed below show the translators and their "aping" counterpart engaging in the acts of reading, offering the translated text before the patrons, or presenting themselves side by side with the authors or patrons. Through their portraits, the translators acquire a most apposite context (the translated text); simultaneously, they become the context that authoritatively informs the translation and the network that is supporting its production and reception. ${ }^{28}$

\section{Imitatio and Imitation}

In their paratexts, authors and translators of Renaissance Italy variously discussed notions and practices of imitation. References to the ancient Roman authorities Horace, Cicero, and Quintilian are most frequent in these paratextual materials. ${ }^{29}$ Horace is often presented as an

\footnotetext{
${ }^{27}$ This taxonomy of self-representation is adapted here from Victor I. Stoichita, The Self-Aware Image: An Insight into Early Modern Meta-Painting, trans. Anne-Marie Glasheen (Cambridge University Press: Cambridge and New York, 1997: reprinted with additions in 2015 by Brepols), pp. 200-206 (pp. 231-237 in the 2015 edition).

${ }^{28}$ Stoichita, The Self-Aware Image, p. 210.

${ }^{29}$ For a discussion of the Italian Renaissance use of these ancient authorities on translation and imitation see Rizzi, Vernacular Translators.
} 
authority who calls for the abandonment of slavish imitation ("a debased form of imitation") when composing poetry. ${ }^{30}$ Horace advised poets to discern between imitation and paraphrase, where the latter is a first step towards understanding the source text (through paraphrase as grammatical exercise), and the former is the technique used to displace the Greek text. Renaissance translators also frequently mention the passage in the De officiis, where Cicero claims to have drawn his material "not as an interpreter, but, as was customary, from the sources I deemed useful". ${ }^{31}$ In the framework of an elite classical education, paraphrase, rewording, and imitation were sequential and necessary stages of the exegesis and rhetorical production of texts. As Quintilian explained in the first century CE:

Their pupils should learn to paraphrase Aesop's fables, the natural successors of the fairy stories of the nursery, in simple and restrained language, and subsequently to set down this paraphrase in writing with the same simplicity of style: they should begin by analysing each verse, then give its meaning in a different language, and finally proceed to a freer paraphrase in which they will be permitted now to abridge and now to embellish the original, so far as this may be done without losing the poet's meaning. ${ }^{32}$

\footnotetext{
${ }^{30}$ Copeland, Rhetoric, Hermeneutics and Translation, pp. 28-29.

31 "not ut interpretes, sed, ut solemus, e fontibus eorum iudicio arbitrioque nostro"; see Rener, Interpretatio, pp. $90-91$.

32 'Igitur Aesopi fabellas, quae fabulis nutricularum proxime succedunt, narrare sermone puro et nihil se supra modum extollente, deinde eandem gracilitatem stilo exigere condiscant; versus primo solvere, mox mutatis verbis interpretari, tum paraphrasi audacius vertere, qua et breviare quaedam et exornare salvo modo poetae sensu permittitur (Institutio oratoria, I.9.2): the Latin text and English translation are from Copeland, Rhetoric, Hermeneutics and Translation, p. 23.
} 
Ultimately, both Horace and Cicero promoted an image of the literary translator "contesting and displacing the source". ${ }^{33}$ These ancient authors proposed a translation that ultimately led to imitation or radical improvement of the source text.

Returning to the portrait in Petrarch's De viris illustribus introduced above, the young man's portrait being held aloft by a monkey and the author's portrait on the same folio were most likely intended to illuminate the nature and scope of the translation. The monkey holding the bust of the young man helps the reader and patron to evaluate whether the text is the product of learned imitation or imitatio. There are only a few other examples from frontispieces and title pages in which monkeys hold the portrait of a translator, a dedicatee, or a depiction of the patron's coat of arms. ${ }^{34}$ The earliest example is in a fourteenth-century book of hours. Marguerite de Beaujeu, patron of the manuscript, is represented kneeling before a scene of the biblical story of the Adoration of the Magi. (Figure 2)

\section{[PLACE FIG. 2 HERE]}

[CAPTION FOR FIG. 2: Figure 2: London, British Library, Add. 36684, fol. $46^{\mathrm{v}}$ (image reproduced from http://www.bl.uk/catalogues/illuminatedmanuscripts/ILLUMIN.ASP?Size=mid\&IllI $\underline{D}=60605$ under creative commons cc0]

\footnotetext{
${ }^{33}$ Copeland, Rhetoric, Hermeneutics and Translation, p. 30.

34 There is no space here to discuss the example from Florence, Biblioteca Mediceo Laurenziana, Plut. 47. 35. On fol. $1^{\mathrm{r}}$ two monkeys rest their backs against the coat of arms of the Sassetti family. The representations of monkeys discussed throughout this chapter differ from those examined by Michael Camille and others: the common, medieval marginal manuscript decorations of babewynerie, or monkey business; the ape as parodic sign, "singe" in Old French, which mocked the human body by imitation. See Michael Camille, 'Play, Piety and Perversity in Medieval Marginal Manuscript Illumination', in Katrin Kroll and Hugo Steher (eds.), Mein ganzer Körper ist Gesicht. Grotesque Darstellungen in der europäischen Kunst und Literatur des Mittelalters, (Freiburg: Rombach Verlag, 1994), pp. 171-192: p. 176.
} 
Marguerite de Beaujeu appears a total of thirty-three times in the margin of this codex. In the instance on folio $46^{\mathrm{r}}$, she is shown being held up by a monkey. ${ }^{35}$ This representation reminds the reader of the "danger of mimesis or illusion in God's created scheme of things", while also making it possible for Beaujeu herself to visualise and "touch" her own prayers. ${ }^{36}$ Here the monkey recalls the Devil's ambition to imitate God; the ape of God, or simia Dei, is the Judeo-Christian Devil. ${ }^{37}$ Yet the image of the female figure kneeling before the Adoration scene also invites her to follow the Word of God.

Both approaches to imitation — that of the good Christian, and that of the Devil—are visualised in this miniature. The uncanny imitator, or the devilish monkey, is shown to reinstate the righteous model of imitation it opposes. ${ }^{38}$ This imagery underscores a key concern in medieval and Renaissance philosophy, theology, and literature: how best to imitate God, and how best to imitate literary authorities. The writings of Thomas Aquinas locate human imitation of God in the soul of the human mind. ${ }^{39}$ Imitation of God can only happen through human understanding and love. Being an animal, the monkey holding

\footnotetext{
${ }^{35}$ London, British Library, Add. 36684, fol. $46^{\mathrm{v}}$. See Elizabeth Moore Hunt, 'The Naked Jongleur in the Margins: Manuscript Contexts for Social Meanings', in Sherry C. M. Lindquist (ed.), The Meanings of Nudity in Medieval Art (Farnham: Ashgate, 2012), pp. 85-103: p. 90. On this book of hours see also Camille, Image on the Edge, p. 30, and Lilian M. C. Randall, Images in the Margin of Gothic Manuscripts (Berkeley and Los Angeles: University of California Press, 1966), p. 195.

${ }^{36}$ Camille, Image on the Edge, p. 13.

${ }^{37}$ Janson, Apes and Apes Lore, pp. 19-22.

${ }^{38}$ Camille, Image on the Edge, pp. 30-31: "Such images work to reinstate the very models they oppose. For behind them, or often literally above them, is the shadow of the model they invert, either on the same page ... or . . by reference to widely known iconographic conventions they subvert”.

${ }^{39}$ Juvenal D. Merriel, To the Image of the Trinity: A Study in the Development of Aquinas' Teaching (Toronto: Pontifical Institute of Medieval Studies, 1990), pp. 132-147.
} 
Beaujeu represents how God should not be imitated — and who should not imitate him. The platform held by the simian figure is therefore the dividing line between "virtuous" and “corrupt" imitation.

Such a dual representation of imitation occurs also in a sixteenth-century transposed portrait of translator Francesco Barozzi (1537-1604). (Figure. 3)

\section{[PLACE FIG. 3 HERE]}

[CAPTION FOR FIG. 3: Figure 3: Portrait of Francesco Barozzi in Procli Diadochi Lycii in primum Euclidis elementorum librum commentariorum ... (Padua: Grazioso Percaccino, 1560), p. 2. Reproduced under CC0]

This portrait appears on page two of his Latin translation of Proclus's Greek commentary on Euclid's Elements - a translation published in Padua, in $1560 .^{40}$ The portrait is held by a wild creature, a monster perhaps, with simian features: toes, ears, and face. As in the case of the portrait of Marguerite de Beaujeu, also in this image the simian-like beast works as a warning against wicked imitation. In his preface to the reader, Barozzi explains that he avoided producing a translation that would be scorned by readers ("quae certe ab omnibus sunt deridendae"). He also avoided obscure and false words (“obscurissima, falsaque"), and did

\footnotetext{
${ }^{40}$ Procli Diadochi Lycii in primum Euclidis elementorum librum commentariorum ad universam mathematicam disciplinam Principiurn eruditionis tradentium libri IIII a F. B . . cunctis mendis expurgati: schoffis et figuris, que in greco codice omnes desiderabantur (sic) aucti: primum iam Romane lingue venustate donate ... (Padua: Grazioso Percaccino, 1560). On Barozzi see the entry 'Barozzi, Francesco', in Dizionario Biografico degli Italiani Treccani (Rome: Istituto dell'Enciclopedia Italiana, 1960-), vol. 6.
} 
not try to bend the scientific language to Ciceronian style. ${ }^{41}$ Barozzi criticises translators who have little or no competence in Greek and science, and therefore "fantasise egregiously" ("egregie hallucinantur"). ${ }^{42}$ Clearly, Barozzi wished his readers to understand that he did not translate by adding much of his own; nor by omitting, or distorting the order of the narrative due to ignorance or incompetence. ${ }^{43}$ Instead, Barozzi explains to his dedicatee, Daniele Barbaro, how he unearthed a series of editions of the Greek text; he edited them diligently ("diligenter emendavi"), while also transcribing them; he also brought all these versions into a single redaction ("ex omnibus exemplaribus quoad fieri potuit unum integrum feci"); he translated the newly restored text into Latin ("converti"), and finally he dispatched the work to the press ("imprimendum illus esse duxi”).

Returning once more to the portrait of the young man in the Valencian copy of Petrarch's De viris illustribus, the monkey supporting the portrait of the young man may therefore be interpreted as reminding the reader and patron of the two, antithetic sides of imitation: on the one hand the skilled imitatio of the literary authority; on the other hand the unskilled aping of the source text and its author. Therefore, the young man does not refer directly to the translator of Petrarch's Latin work, Donato degli Albanzani (ca. 1397), but to slavish and creative approaches to imitation. For late medieval and Renaissance students, authors, and translators eloquence — persuasive speech or writing — was part and parcel of the

\footnotetext{
41 “aut demum quia quum Ciceroniana lingua scientiarum vocabula (quod fieri non potest) exprimere voluerint, inextricabiles Labyrinthos ingressi": Procli Diadochi Lycii in primum Euclidis elementorum librum commentariorum, p. 13.

${ }^{42}$ Procli Diadochi Lycii in primum Euclidis elementorum librum commentariorum, pp. 13-14.

43 “neque eos imitati sum, qui in vertendis libris non pauca de suo adijciunt, permulta praetermittunt, aut seriem Autorum, atque ordinem perturbantes commutant" (Procli Diadochi Lycii in primum Euclidis elementorum librum commentariorum), p. 13.
} 
pursuit of both personal and cultural excellence, and was accorded the power to influence contemporaries and future generations. ${ }^{44}$ The ability to adapt Greek and Latin eloquence to various audiences and texts conveyed the social status of the writer. The young man represented in the Valencian manuscript might have been read, therefore, as the budding learner and author who, by means of translation, enters into a dialogue with literary authorities such as Petrarch. The presence of the monkey below the young man serves as a reminder of the dangers of unskilled imitation, and alerts the learner, reader, and translator to what a praiseworthy imitator should do. In the words of Petrarch,

The imitator must take care that what he writes is not the same, and this similarity should be not like that of a portrait to the man portrayed ... but like that of a son to his father. So we too must take pains that while some element is like, many things are unlike, and the actual likeness is hidden so as not to be detected except by the unvoiced investigation of the mind. ... [T] he first makes poets, the other apes. ${ }^{45}$

Indeed, these words by Petrarch must have inspired the miniaturist and patron of the Valencian manuscript. The father-son relationship is visualised in the two portraits of Petrarch and the young, bare-chested man, while the monkey represents what a poet (and

\footnotetext{
${ }^{44}$ Patrick Baker, Italian Renaissance Humanism in the Mirror (Cambridge: Cambridge University Press, 2015), p. 29.

${ }^{45}$ Petrarch, Familiares, 23.19: "Curandum imitatori, ut quod scribit simile non idem sit, eamque similitudinem talem esse oportere, non qualis est imaginis ad eum cuius imago est ... sed qualis filii ad patrem .... Sic et nobis providendum ut cum simile aliquid sit, multa sint dissimilia, et id ipsum simile lateat ne deprehendi possit nisi tacita mentis indagine, ut intelligi simile queat potiusquam dici. ... Illa poetas facit, haec simias". Text and translation from Francesco Petrarca. Selected Letters, trans. Elaine Fantham (2 vols., Cambridge MA: Harvard University Press, 2017), I. 353-355.
} 
translator) would best avoid becoming. The youth in the Valencian manuscript, like Marguerite de Beaujeu in her book of hours, gaze at their holy and literary models. Instead, Barozzi the translator looks directly into the reader's eyes in an unsettling and assertive fashion: the authoritative portrait of the translator is challenged by the symbols of monstrous imitation that enframe him; the simian monster and the two fearsome faces caution the translator, reader, and patron to eschew ape-like imitation.

There is a further example of a translator's portrait being presented as an explicit contrast to an image of monkeys. In this case, two simian creatures face one another while sitting on the ground. Framed in a roundel, they appear at the top right of the title page of Donato Acciauoli's 1480 Florentine vernacular translation of Leonardo Bruni's Historia florentina. The title letter shows a portrait of a humanist scholar at work on his desk, most likely the translator himself. ${ }^{46}$ The contrast between the two monkeys sitting down and facing each other and the humanist at work on the translated text is unambiguous. The monkeys mirror each other, whereas the translator is represented in the act of imitating the source text. This manuscript's illuminator, the so-called Master of the Hamilton Xenophon, provides a further visual cue by depicting a youth — an element which probably bears the same significance of the young man represented in the Valencian manuscript discussed above. This youth portrait is positioned directly opposite the monkeys. Here the imagery proposes, therefore, a contrast between learning and imitatio (represented by the youth and translator) and the beastly self-imitation of the monkeys. It offers readers and dedicatees a visual representation of the prestige and quality of the translation as a source of learning and the product of skilful imitatio.

\footnotetext{
${ }^{46}$ Miniatura fiorentina, I.158; Florence, Biblioteca Nazionale, Banco Rari 53, fol. $1^{\mathrm{r}}$.
} 


\section{In the Company of Monkeys (and Dogs)}

The transposed portraits discussed in this section show translators representing themselves (or being represented by artists and printers) at court, and in the act of offering their work to their patrons. The iconography of book dedication is extremely common in late medieval and Renaissance scribal cultures, and it certainly cannot be delineated adequately here. ${ }^{47}$ I should also add that the miniatures, woodcuts, and engravings discussed below were produced by Flemish, French, and English artists and printers of different fifteenth and early sixteenthcentury French and Burgundian courts. Despite being produced for different rulers and readers, these images share a highly similar iconography. The key element of interest is the prominence of monkeys and dogs positioned beside translators and patrons. As in the images analysed in the previous section, also in these cases the mise en page of monkeys and dogs in the miniatures and engravings serves to signify discrete types of translation: the authoritative and eloquent imitatio of ancient sources and authors. At the same time, these representations signal an increased self-awareness on the part of Renaissance translators.

\footnotetext{
47 'Italian' examples include Albi, Bibliothèque Municipale, 77, fol. $3^{\mathrm{v}}$ (Guarino of Verona presenting his translation to Jacopo Marcello, ca. 1459); Paris, Bibliothèque National de France, Lat. 4801, fol. $2^{\mathrm{r}}$ (Jacopo Angeli da Scarperia presenting his translation to Pope Alexander III, ca. 1409), and Valencia, Biblioteca Universitat de Valencia, 392, fol. $4^{\mathrm{r}}$ (Valla offering his translation to Pope Nicholas V, ca. 1450). French examples are London, British Library, Royal 14 E VI, fol. $10 r$ (Jean Corbechon presenting his translation to Charles V King of France, $c a$. 1478); London, British Library, Royal 15 D IV, fol. $11^{\mathrm{r}}$ (Vasco de Lucena to Charles the Bold); London, British Library, Royal 17 F III, fol. $1^{\mathrm{r}}$ (Raoul des Presles to Charles V King of France, $c a$. 1479). English examples include London, British Library. Royal 20 B IV, fol. $1^{\mathrm{r}}$ (Jean Galopes offering his translation to Henry V King of England, and lord of Ireland, ca. 1420), and London, British Library, Royal 14 E V, fol. $5^{\mathrm{r}}$ (Laurent de Premierfait to Jean, Duke of Berry, ca. 1409).
} 
A miniature dated circa 1534 shows King François I at his court. (Figure. 4) ${ }^{48}$

\section{[PLACE FIG. 4 HERE]}

[CAPTION FOR FIG. 4: Figure 4: Musée Condé, Chantilly, MS. 721/1672 f.1r. Antoine Macault presents his translation to François I, from Books I, II and III' by Diodorus Siculus (ca.90-ca.20 BCE), ca.1532 (vellum), French School (16th century). By permission of Musée Condé, Chantilly, France / Bridgeman Images]

The king is shown surrounded by his three sons, as well as Cardinal Duprat, the king's pet monkey, and courtiers. François I is listening to and watching Antoine Macault—king's secretary and valet de chambre — while reading his French translation of Diodorus Siculus's history. In his preface to the king, the translator reveals that he had given a lecture to the court of François I in 1534. The same miniature was subsequently turned into an engraving for the 1535 printed edition (see figure 5), and the engraving was subsequently reused for Macault's 1549 translation of Cicero's Philippics made at Poitiers. ${ }^{49}$

\footnotetext{
${ }^{48}$ Chantilly, Musée Condé, 721 , fol. $1^{\mathrm{v}}$ ( $\left.c a .1534\right)$. This miniature is by the so-called workshop of the 1520 book of hours, following the style of Noël Bellemare. It has been suggested that the artist Jean Clouet painted at least some of the figures in this miniature. See Cécile Scaillièrez, 'Un portrait méconnu de François Ier peint par Jean Clouet. Le frontispice des Histoires de Diodore de Sicile au musée Condé de Chantilly’, Revue du Louvre, 4 (1996), pp. 47-52, and Pierre-Gilles Girault, François Ier, images d'un roi. De l'histoire à la légende (Paris: Somogy éditions, 2006), p. 66.

${ }^{49}$ Diodore de Sicile, Histoire universelle, les trois premiers livres, traduit par Antoine Macault (Paris: Galliot du Pré et Antoine Augereau vend Olivier Mallard, 1535). The engraving is on p. bbiiiiv. One version of the 1535 edition, printed on vellum, was prepared for King of England Henry VIII. See Ruth Mortimer, A Portrait of the Author in Sixteenth-Century France (Chapel Hill: Hanes Foundation, 1980), pp. 14-15. For similar portraits of authors presenting their work see Cynthia J. Brown, “Text, Image, and Authorial Self-consciousness in Late Medieval Paris", in Printing in the Written Word: The Social History of Books, circa 1450-1520, ed. Sandra Hindman (Ithaca NY: Cornell University Press, 1991), pp. 103-142: pp. 103-106.
} 


\section{[PLACE FIG. 5 HERE]}

[CAPTION FOR FIG. 5: Figure 5: Antoine Macault reading his translation of Diodorus Siculus to King Francis I. Image reproduced from Joseph Cundall, A Brief History of Wood-engraving from its Invention, 1895, under CC0)]

In all three versions of this image the King of France is surrounded by his three sons: dauphin François, Henry Duke of Orléans, and the youngest son, Charles Duke of Angoulême.

Charles too glances in the direction of the translator, while with his right hand he gestures for the dog to be quiet. An unidentified member of the court stands before the king, dressed in black like the translator, and standing on the far right side of the image, almost mirroring Macault. The presence of a dog and a monkey in this courtly scene has never been examined in any detail. Often used as symbol of faithfulness, dogs were also beloved pets at courts. ${ }^{50}$ In this example, their mise en page suggests, however, that the monkey and dog symbolise the translator's work and skills. In all three versions of this image, the monkey looks the opposite way from the translator. Instead, the dog is looking in the direction of Macault, leashed under the strict control of the king's youngest son.

Earlier images, by Flemish illuminators, show French and English translators offering their work to rulers from a position in which they are beside a monkey and a dog. In a late fifteenth-century Flemish copy of Simon de Hesdin and Nicolas de Gonesse's translation (made circa 1475) of historical anecdotes by Valerius Maximus, Hesdin is portrayed offering his work to Charles V King of France. (Figure 6)

[PLACE FIG. 6 HERE]

[CAPTION FOR FIG. 6: Figure 6: London, British Library, Harley 4430, fol. $33^{\mathrm{r}}$ (ca. 1475): Valerius Maximus, translated into French by Simon de Hesdin and Nicolas de

\footnotetext{
${ }^{50}$ Simona Cohen, Animals as Disguised Symbols in Renaissance Art (Leiden: Brill, 2008), p. 211.
} 
Gonesse (ca. 1375-1401). Reproduced from

http://www.bl.uk/catalogues/illuminatedmanuscripts/ILLUMIN.ASP?Size=mid\&IllI $\underline{\mathrm{D}=14398}$, under CC0]

Both the dog and the chained monkey parade in the foreground, with the fettered monkey being chased away by the dog. ${ }^{51}$ Yet another representation of translator with monkey and dog appears is in a copy of Laurent de Premierfait's 1409 French translation of Boccaccio's De casibus virorum illustrium dating to circa 1479 . (Figure 7) ${ }^{52}$

\footnotetext{
${ }^{51}$ London, British Library, Harley 4430, fol. $33^{\mathrm{r}}$. On this manuscript see Dorothy M. Schullian, 'A Revised List of Manuscripts of Valerius Maximus', Miscellanea Augusto Campana. Medioevo e Umanesimo, 45 (1981), pp. 695-728: p. 708. On Gonesse and Hesdin see Graziella Pastore, 'Petrarca, Boccaccio e l'Italia nella traduzione
} francese dei Facta et dicta memorabilia di Valerio Massimo', Le Moyen Français, 66 (2010), pp. 87-100, and Marcel Lecourt, 'Une source d'Antoine de la Sale: Simon de Hesdin', Romania, 76 (1955), pp. 39-83, and pp. 182-210. In another fifteenth-century copy of Hesdin's translation of Valerius Maximus's Facta et dicta memorabilia (Paris, Bibliothèque Nationale, Fr. 6185 , fol. $243^{v}$ ), there is a miniature representing an artist at work polychroming a statue. The artist is distracted by a statue (or is it real?) of a monkey eating a fruit. The fruit eating ape is a common trope for vice, harking back to the first sin of Adam and Eve. In this miniature, the monkey alerts the artist of the "impossibility of representing nature". Just below the miniature, the translator comments on the Athenian painter who tried to portray the gods. The translator reminds the reader of the fallibility of mankind and warns of the dangers of pride and ambition. See Michael Camille, The Gothic Idol: Ideology and Image-Making in Medieval Art (Cambridge: Cambridge University Press, 1989), p. 48. Obviously, this imagery differs substantially from the one discussed in this chapter.

${ }^{52}$ London, British Library, Royal $14 \mathrm{E} \mathrm{V}$, fol. $5^{\mathrm{r}}$. Premierfait produced two versions of this translation: the first was a failure because of its word-for-word approach to the source text. On the miniaturist of this manuscript (the so-called Master of the White Inscription) and Premierfait see Margaret Kekewich, 'Edward IV, William Caxton, and Literary Patronage in Yorkist England', The Modern Language Review, 66 (1971), pp. 481-487: p. 484, and Anne D. Hedeman, Translating the Past: Laurent de Premierfait and Boccaccio's De Casibus (Los Angeles: Getty Publications, 2008). 
[PLACE FIG. 7 HERE:

[CAPTION FOR FIG. 7: ] Figure 7: London, British Library, Royal 14 E V, fol. $5^{\text {r }}$ (reproduced from

http://www.bl.uk/catalogues/illuminatedmanuscripts/illumin.asp?size=mid\&illid=506 25. Reproduced under CCO]

The translator offers his work to Jean Duke of Berry. Once again, a monkey and translator are in the foreground, but in this case a boy is training the dog and a monkey. In this image, only the ape is on a leash. A wand-holding court jester is behind the boy and pets, and the monkey seems to be aping him by holding a stick. The monkey's posture also imitates the translator's; both face the master they deserve. This scene and all three images of François I's court connect with an imagery that harks back to the twelfth century, in which the monkey is represented as a performing animal. Such images of fettered apes being controlled by their handler variously suggest the chastisement of vice. They also remind their viewers that apes were trained to imitate moves and actions of humans, while being beaten and disciplined by their handlers. ${ }^{53}$ In the words of Benedictine author and commentator Pierre Bersuire (12901362):

\footnotetext{
${ }^{53}$ Janson, Apes and Apes Lore, p. 49 and pp. 146-47. Another example of a fettered monkey looking away from the translator and facing a member of the court (possibly its handler) is Paris, Bibliothèque Nationale de France, Fr. 22547, fol. $1^{\mathrm{r}}$. This manuscript contains a copy by Yvon the Young of Vasco da Lucena's French translation of Quintus Curtius's Histoires du grant Alexandre de Macedone - a translation that was presented to King Charles the Bold of France in 1470. On exotic animals at court and their handlers see Sarah Cockram, 'Interspecies Understanding: Exotic Animals and their Handlers at the Italian Renaissance Court', Renaissance Studies, 31 (2017), pp. 277-296.
} 
The apes are mankind ... and the chains the evil pleasures, complacency, and habit .... They are tied to the block, i.e. burdensome affairs of this world, and are taught to perform before the devilish master. ${ }^{54}$

Arguably, in this representation, the captivity of the ape contrasts the translator's free choice to offer his literary efforts to his ruler.

Another scene of book offering appears in a lavishly illuminated manuscript dating to circa 1482, and features a fettered monkey and a dog side by side. This time, the human figure is not a translator in the strict sense, but a historian who gathered various sources together in order to produce a commentary on the 1480 siege of Rhodes: this was Guillaume Caoursin (ca. 1430-1501), a French knight and an eye-witness to the siege. In this image he is shown kneeling before the Master of the Order of the Knights of Malta, Pierre d'Abusson, Caorsin's dedicatee. ${ }^{55}$ The monkey and dog are placed directly below the dedicatee's seat.

\footnotetext{
${ }^{54}$ Janson, Apes and Apes Lore, p. 147. Pierre Bersuire translated Livy’s Ab urbe condita into French for Hesdin and de Gonesse's same patron, King Charles V, which makes it plausible that the illuminator of the French version of Valerius Maximus were influenced by Bersuire's interpretation of the chained ape's imagery.

${ }^{55}$ Paris, Bibliothèque Nationale de France, Lat. 6067, fol. $3^{\mathrm{r}}$. In his preface to the dedicatee, the author writes: "Hos itaque commentarios ab ingegnosi facultate profectos ad omnipotentis dei laudem ac tui nominis commilitonumque tuorum famam haud perituram tibi dedico" ("I offer these commentaries derived from an ingenious collection of sources to glory of God the omnipotent, and to the immortal reputation of your name and of the members of your order"), fol. $2^{\mathrm{v}}$. The manuscript is the dedication copy and contains an account in Latin of the siege of Rhodes (1480): Gestorum Rhodie obsidionis commentarii. The codex is lavishly illuminated by the so-called Master of the Cardinal of Bourbon. Several of the views of Rhodes depicted in these miniatures have been studied; see, for instance, Tamar Choloman and Asaaf Pinkus (eds.), The Sides of the North: An
} Anthology in Honor of Professor Yona Pinson (Cambridge: Cambridge Scholars Publishing, 2015), p. 113. Unfortunately, the dedication image discussed here has not studied. This manuscript is available online from the Bibliothèque Nationale de France Gallica repository. 
The monkey copies the author's gesture of offering the book. Yet the ape's imitation is purposeless, since the monkey has nothing to offer. Behind the dedicatee, two monkeys perched on windowsills are instructed or tamed by handlers. The dog's symbolic relationship to the monkey's gesture may be interpreted as a reminder for the viewer of the non-material value of loyalty.

A final example of an image comprised of similar elements is found in an engraving by William Caxton, in which he is depicted offering two volumes to Margaret of York, Duchess of Burgundy. (Figure 8) $)^{56}$

[PLACE FIG. 8 HERE]

[CAPTION FOR FIG. 8: ] Fig. 8: Printer William Caxton (1415-1492) Presenting His Translation to Margaret of York (1446-1503). Copy of Recuyell Of Historyes Of Troye, Engraving, Huntington Library, San Marino, CA. By permission of De Agostini Picture Library / Bridgeman Images.

\footnotetext{
${ }^{56}$ See Joseph A. Dane, “'Wanting the First Blank”: Frontispiece to the Huntington Copy of Caxton's Recuyell of the Historyes of Troye', Huntington Library Quarterly, 67 (2004), pp. 315-325. See also Yu-Chiao Wang, ‘Caxton's Romances and Their Early Tudor Readers', Huntington Library Quarterly, 67 (2004), pp. 173-188. Scholars have offered various interpretations of the monkey in this scene. Deanne Williams suggested that the portraits of monkey and Caxton together highlight the hybridity of the exchange: the barbarian tongue (English), and the sophisticated French narrative. See Deanne Williams, The French Fetish from Chaucer to Shakespeare (Cambridge: Cambridge University Press, 2005), p. 91. William Kuskin interprets the monkey as a disruptive element to underscore the translation as a commodity and the translator as an outsider, a cultural broker to be subjected to ridicule; see William Kuskin, Symbolic Caxton (Notre Dame, IN: University of Notre Dame Press, 2008), pp. 100-101. See also a forthcoming interpretation by Anne E. B. Coldiron, 'The Translator's Visibility in Early Printed Portrait-Images', in M. Belle and B. Hosington (eds.), Thresholds of Translation: Paratexts, Print, and Cultural Exchange in Early Modern Britain (London: Palgrave, forthcoming 2017). I am grateful to Coldiron for allowing me to read her work before its publication.
} 
Present only in the Huntington Library copy, this engraving accompanies Caxton's English translation of Raoul Le Fèvre's Recuyell of the Historyes of Troye, printed at Bruges circa 1473 - a book often referred to as the first book printed in the English language. The scene shows an unbridled monkey crouching between Caxton and the Duchess. This ape is imitating the gesture of the translator: that is, imitating as performing pets were trained to do. Also, in this instance, the monkey is empty-handed, which underscores the pointless but entertaining imitative performance of the trained pet. A dog is present in the scene, except that here it is held by one of Margaret of York's ladies-in-waiting. Margaret of York was the wife of Charles the Bold, to whom Vasco de Lucena had dedicated a French version of Quintus Curtius containing a dedication scene with a monkey and dog. ${ }^{57}$

What might these prominent images of monkeys and dogs have meant to the translators and their audiences? Recent interpretations of the monkey in Caxton's text suggest that it represents Caxton himself, as a self-consciously humble cultural agent presenting a service — or the commodity itself; that is, the printed text. However, these interpretations neglect the presence of the dog and the tradition of representing monkeys and dogs in the dedication of translations. One answer to the above question might well be sought in the translators' prefaces that accompany the dedication imagery. In his 1535 prologue, Macault establishes a connection between translation ("translater") and original composition ("escripere"). For these two activities to succeed, the translator needs to be careful not to translate too literally or faithfully; careful to avoid slavish imitation of a single style or author at the cost of originality and elegance of style. Macault rejects slavish imitation, opting rather for fidelity to the sententia, and adaptation of the style of the source text. ${ }^{58}$ For this reason,

\footnotetext{
${ }^{57}$ See $n 53$ above.

${ }^{58}$ Glyn Norton, The Ideology of Language of Translation in Renaissance France and their Humanist Antecedent (Geneva: Droz, 1984), p. 189 (n. 12).
} 
perhaps, in Macault's scene the monkey is looking away from the translator: the ape is not imitating Macault and therefore, mutatis mutandis, the translation is not aping the author (see figure 5). This preface and the accompanying image affirm the translator's literary creativity, and enhance the "dominant, personalised authority" of the translator. ${ }^{59}$ The presence of the dog serves as a counterbalancing element to reassure the dedicatee and reader that the translation nonetheless is still faithful to the content and style of the translated text.

Caxton's preface reveals a different scenario. In this case, the monkey is positioned between the figures of the translator and dedicatee, and faces the translator so as to imitate his act of offering. The image is reinforced by Caxton's preface, in which he downplays his literary and linguistic skills as translator, and declares his failed attempt to imitate the French author's work:

forthwyth wente and labouryde in the sayde translacion aftyr my symple and pour connyng also nigh as y can folouyng myn auctour mekeli beseeching the bounteuous hyenes of my said lady that of her be|nyuolence lifte to accepte \& take in gree this symple $\&$ rude werke here folowyng. ${ }^{60}$

Caxton proposes his "rude \& symple translacion" as even more lacking in skill (and thus "ape-like") by presenting the work of the French author as a translation "composed and drawen out of dyuerce bookes of latyn in to frensshe". This presentation of Le Fèvre's work as a translation of several sources is akin to the way in which, just over a decade later, Caoursin would summarise and defend for the benefit of his dedicatee, Pierre d'Abusson. Caoursin gathered reliable accounts of the siege of Rhodes, thus avoiding the use of only one

\footnotetext{
${ }^{59}$ Brown, ‘Text, Image’, p. 104.

${ }^{60}$ Caxton, Recuyell of Historyes of Troye.
} 
account or source. ${ }^{61}$ Such a statement is reminiscent of Leonardo Bruni's influential discussion, in the preface to his Commentarii de primo bello punico (1418-21), on the superior nature of his commentaria: Bruni's work is presented not as a translation solely from the Greek of Polybius, but as an account selectively drawn and integrated from several sources. ${ }^{62}$ The freedom and authority of the translator or historian is therefore affirmed also in the case of Caoursin's work: in the dedication scene, monkey and dog face each other, denoting a contrast between slavish imitation and faithfulness towards the narrative. As in the case of Macault's portrait, the monkey turns away from Caoursin, while the dog gazes in his direction.

An even clearer iconography is shown in the portrait of Hesdin offering his translation to King Charles V (see figure 7). Here the fettered monkey is chased away by the dog as the ape tries to imitate Hesdin's offering gesture. This action among the animals can be interpreted as an outright rejection of the word-for-word, or "rude" and imperfect translation described by Caxton. Such rejection is underscored in Hesdin's preface, which explains his choice to translate ad sensum so as to make the narrative understandable and enjoyable. ${ }^{63}$ The

\footnotetext{
${ }^{61}$ The passage is quoted above, n. 55.

${ }^{62}$ This work by Bruni was circulated widely in Renaissance Europe; see Gary Ianziti, Writing History in Renaissance Italy: Leonardo Bruni and the Uses of the Past (Cambridge: Harvard University Press, 2012), pp. $67-68$.

${ }^{63}$ This approach to translation was favoured by Charles V. See Hedeman, Translating the Past, p. 9. Here is the full passage from Hesdin's prologue: “Item il est assavoir que m'entente n'est ne ne fu onques de translater cest livre de mot a mot, car ce seroit aussi comme impossible de translater le en celle maniere et que sentence y fust trouvee entendable ne delitable, au mains en la plus grant partie, et les causes si sont la brieve et estrange maniere de parler, la difficulté du latin et le merveilleus stille du livre et pour ce est mon entente de translater le de sentence a sentence et de faire de fort latin cler et entendable romant, si que chascun le puist entendre, et, ou la sentence sera obscure": London, British Library, Harley 4732, fol. $12^{\mathrm{v}}$. I have checked this text against the
} 
scene in which Premierfait offers his translation to John of Berry supports a similar interpretation. Premierfait's 1409 translation of Boccaccio's De casibus contains perhaps the most exhaustive account of a fifteenth-century translator's approach to his source. "It is necessary", Premierfait explains, "that Latin books should be changed and converted in their translation into such language that their readers and listeners can understand the effect of the sentence without enormous or long efforts". ${ }^{44}$ The translator thus legitimises his authorial freedom for the benefit of the reader and dedicatee while reassuring his audience of the reliability of the translated narrative.

The images and texts examined herein witness translators', printers', and patrons' strong engagement with the perennial debate concerning the acceptable parameters of literary imitation. As such, they demonstrate a complex relationship between translation and authority, whereby imitatio is generally the translator's preferred choice; an imitation that, in accordance with the most praised and praiseworthy notions of textual translative practice, includes scope for significant creative interpolation. The quest to use translation as a creative force — by rejecting or asserting distance from imagery and similes of the aping monkey_ allowed most of the translators discussed in this chapter to calibrate, promote, and defend their role and image before their dedicatee and readers.

online edition of Book One by Maria Cristina Enriello of Paris, Bibliothèque Nationale, Fr. 9749 (http://www.pluteus.it/wp-content/uploads/2008/11/valere-maxime-i-libero.pdf, last accessed 12 January 2017).

${ }^{64}$ This passage from Premierfait's preface to his translation of De Casibus is taken from Hedeman, Translating the Past, p. 13. 
Imagery of the ape destabilised perceptions of the translator's role and skills, while reminding the viewer that the business of the translator was, ideally, to imitate the source text skilfully and entertainingly. Thus the presence of monkeys (and dogs) in the above images can be described as sophisticated evidence of self-awareness, documenting in each case the translator's performative practice of being conspicuous. ${ }^{65}$ These artistic images also demonstrate one of the several means through which Renaissance translators made themselves, or were allowed to be, visible to their readers and patrons. By exploiting both scribal and print technologies, and collaborative relationships within the book industry, translators enhanced possibilities for self-expression within courts and across a broader range of networks.

\footnotetext{
${ }^{65}$ Douglas Biow, In Your Face: Professional Improprieties and the Art of Being Conspicuous in SixteenthCentury Italy (Stanford: Stanford University Press, 2010), pp. 25-27.
} 
CHAPTER 3

\title{
Rhetorical Ethos and the Translating Self in Early Modern England
}

\author{
Marie-Alice Belle
}

In his recent account of the economy of dedication and patronage in early modern England, Richard McCabe underscores the importance of liminal discourse for writers seeking to secure a powerful patron and an extended readership for their attempts at the "ungainefull arte" of writing poetry. ${ }^{1}$ His analyses of the acts of negotiation performed in the margins of early modern printed poems confirm what historians of early modern English print culture such as Martin Elsky, Harold Love, Adrian Johns, or Michael Saenger have identified as the essential paradox of "print authorship". The paradox can be described as the complex interplay of private identity and public recognition through which authors lend their cultural authority to printed books - while allowing the same authority to be constructed and validated through the material features, the social success, and the commercial success of the printed artefact. $^{2}$

\footnotetext{
${ }^{1}$ Richard A. McCabe, 'Ungainefull Arte': Poetry, Patronage, and Print in the Early Modern Era (Oxford: Oxford University Press, 2016).

${ }^{2}$ Martin Elsky, Authorizing Words: Speech, Writing and Print in the English Renaissance (Ithaca: Cornell University Press, 1989); Harold Love, 'Early Modern Print Culture: Assessing the Models', Parergon 20 (2003), pp. 45-64; Adrian Johns, The Nature of the Book: Print and Knowledge in the Making (Chicago: Chicago University Press, 2008); Michael Saenger, The Commodification of Textual Engagements in the English Renaissance (Aldershot; Burlington VT: Ashgate, 2006); see also Margaret Ezell, Social Authorship and the Advent of Print (Baltimore MD: Johns Hopkins University Press, 1999).
} 
Many of the examples in McCabe's study are taken from translations. This is hardly surprising, given the importance of translated texts to the early modern market for printed books. Brenda Hosington's Renaissance Cultural Crossroads Catalogue of printed translations has recently demonstrated the numerical importance of translations. They were also of immense cultural importance. ${ }^{3}$ One need only think of the amount of scholarship recently devoted to the case of John Harington's 1591 Orlando furioso, a translation which has often been read as an exemplar of the combined practices of book production and circulation, of strategic cultural and social positioning, and of authorial (or translatorial) self-fashioning that accompanied the rapid development of a market for printed books in early modern Britain. ${ }^{4}$

Further, in a culture where the ancient trope of translatio studii (that is, the mythical transfer of knowledge and power from East to West) provided the dominant

\footnotetext{
${ }^{3}$ Brenda Hosington (ed.), Renaissance Cultural Crossroads Catalogue of Printed Translations, 1473-1640, available online: https://www.hrionline.ac.uk/rcc/; see also Brenda Hosington, 'The "Renaissance Cultural Crossroads" Catalogue: A Witness to the Importance of Translation in Early Modern Britain', in Malcolm Walsby and Graeme Kemp (eds.), The Book Triumphant: Print in Transition in the Sixteenth and Seventeenth Centuries (Leiden: Brill, 2011), pp. 253-269; and, Brenda Hosington, 'The Role of Translations and Translators in the Production of English Incunabula', in Sara Barker and Brenda Hosington (eds.), Renaissance Cultural Crossroads: Translation, Print, and Culture in Britain, 1473-1640 (Leiden: Brill, 2013), pp. 3-20.

${ }^{4}$ See, among others, Jason Scott-Warren, Sir John Harington and the Book as Gift (Oxford: Oxford University Press, 2001); Gerard Kilroy, 'Advertising the Reader: Sir John Harington's "directions in the Margent” [with Illustrations]', English Literary Renaissance, 41 (2012), pp. 64-110; Guyda Armstrong, 'Coding Continental: Information Design in Sixteenth-Century English Vernacular Language Manuals and Translations', Renaissance Studies 29 (2015), pp. 78-102.
} 
pattern in discussions of Britain's cultural, political, and intellectual identity, the imagery of translation came to function as a heuristic model when articulating the various acts of negotiation involved in the production, dedication, and circulation of printed texts. In their prefaces and dedications, translators routinely staged fictional encounters and dialogues with their authors. They defended their own trustworthiness and good intentions in bringing new texts and ideas into the English public sphere. They also addressed the often ambivalent responses provoked by voyages of the translated text, from one cultural and linguistic sphere to another, or from the closed circles of the literati to a broadened vernacular audience. These themes obviously converged with, and even nourished ongoing concerns about the parallel orders of manuscript and print circulation (and the so-called "stigma of print"). They also spoke to the printed author's dual and sometimes conflicting relationship towards a carefully selected patron, on the one hand, and the anonymous multitude of "gentle readers", on the other hand. It is therefore revealing that the language of travel, dialogue, exchange, and other forms of "intertraffic" should be so prevalent in the liminal spaces of printed books. ${ }^{5}$

\footnotetext{
${ }^{5}$ See Warren Boutcher, 'Intertraffic: Transnational Literatures and Languages in Late Renaissance England and Europe', in Matthew McLean and Sara K. Barker (eds.), International Exchange in the Early Modern Book World (Leiden: Brill, 2016), pp. 343-374; also Peter Burke, ‘The Translator As Go-Between', in Andreas Höfele and Werner von Koppenfels, Renaissance Go-Betweens: Cultural Exchange in Early Modern Europe (Berlin: De Gruyter, 2005), pp. 17-31; or again, Brenda Hosington, 'Translation as a Currency of Cultural Exchange in Early Modern England', in Helen Hackett (ed.), Early Modern Exchanges: Dialogues Between Nations and Cultures, 1550-1750 (New York: Routledge, 2016), pp. $27-$ 54.
} 
In the past few years, a number of important studies have brought to the forefront the significance of such acts of cultural negotiation and individual self-fashioning in early modern translation practice. While translation prefaces had long been regarded as mere repositories of threadbare commonplaces, recent work on early modern translation topoi has revealed them to point to a number of "shared concerns" among English writers and translators. ${ }^{6}$ In parallel, we have come to recognise the ambiguities of early modern translation discourse — in particular the translator's legendary humility topos — as a range of strategies, designed for a variety of purposes. In some cases, the strategies helped assuage the "status anxiety" of translators in early modern literary culture. ${ }^{7}$ In others, especially among women translators, they served to manipulate cultural assumptions, and thereby — paradoxically enough — to carve out a space of authorial recognition. ${ }^{8}$ Liminal

\footnotetext{
${ }^{6}$ Namely: the status of the English language among ancient and vernacular idioms; the role of translation as an instrument of cultural importation and a nation-building enterprise; its nature as a rhetorical and poetical practice; and the question of its appropriate place in the emerging English literary canon. See Anne Coldiron, 'Commonplaces and Metaphors', in The Oxford History of Literary Translation into English, Gordon Braden and Robert Cummings (eds.) (5 vols., Oxford: Oxford University Press, 2010), II, pp. 109120, at p. 109.

${ }^{7}$ Neil Rhodes, 'Status Anxiety and English Renaissance Translation', Helen Smith and Louise Wilson (eds.), Renaissance Paratexts (Cambridge UK: Cambridge University Press, 2011), pp. 107-120.

${ }^{8}$ See on this Patricia Pender, Early Modern Women's Writing and the Rhetoric of Modesty (Basingstoke: Palgrave Macmillan, 2012), and in more specific relationship to translation, Danielle Clarke, 'Translations', in Laura Knoppers (ed.), The Cambridge Companion to Early Modern Women's Writings (Cambridge: Cambridge University Press, 2010), pp. 167-180; Jaime Goodrich, Faithful Translators: Authorship, Gender, and Religion in Early Modern England (Evanston IL: Northwestern University Press, 2014); Patricia Demers's introduction to her edition of Anne Cooke Bacon's Apology or Answer in Defence of The
} 
discourse has thus been recognised to represent a space of self-fashioning and strategic “visibility" for translators, a place where gestures of linguistic, social, and cultural negotiation were advertised and problematised in a highly self-conscious manner. ${ }^{9}$

This chapter explores the critical potential of the notion of rhetorical ethos. Although a concept that often surfaces in discussions of early modern self-presentation and self-fashioning strategies, its significance to early modern English translation discourse has mostly remained unexamined to this day. First discussed in Aristotle's Rhetoric as the art of establishing a trustworthy character, and one of the most effective means of persuasion, the notion of ethos underwent a complex process of reception in early modern England. Recent studies by Quentin Skinner and Kevin Dunn, among others, have highlighted its significance to early modern English rhetoric, and more specifically to genres such as the verse epistle, or indeed, the preface. ${ }^{10}$ Without offering

Church Of England (London: MHRA, 2015).

${ }^{9}$ As forcefully argued by Anne Coldiron in particular; see her studies, 'Visibility Now: Historicizing Foreign Presences in Translation', Translation Studies 5 (2012), pp. 189-200; Printers Without Borders: Translation and Textuality in the Renaissance (Cambridge: Cambridge University Press, 2015), and 'The Translator's Visibility in Early Printed Portrait-Images and the Ambiguous Example of Margaret More Roper', in Marie-Alice Belle and Brenda Hosington (eds.), Thresholds of Translation: Paratexts, Print, and Cultural Exchange in Early Modern Britain (Basingstoke: Palgrave MacMillan, forthcoming, 2017).

${ }^{10}$ See Quentin Skinner, Reason and Rhetoric in the Philosophy of Hobbes (Cambridge: Cambridge University Press, 1996), pp. 128-134; Kevin Dunn, Pretexts of Authority: The Rhetoric of Authorship in the Renaissance Preface (Stanford: Stanford University Press, 1994); Steven Shelburne, 'The Epistolary Ethos of Formal Satire', Texas Studies in Literature and Language 36 (1994), pp. 135-165; Melvin Blaine, 'Envy, Eunoia and Ethos in Jonson's Poems on Shakespeare and Drayton', Studies in Philology 106 (2008), pp. $441-455$. 
a detailed analysis of the notion, McCabe also rightly points that the rhetoric of early modern English paratexts heavily relied on "traditional topoi designed to establish an orator's ethos, or moral character". ${ }^{11}$ Ironically, however, the concept of ethos is virtually absent from critical discussions of translation discourse in the early modern period, even though classical rhetoric is known to have provided the theoretical, discursive, and practical basis for the "art" of translation. ${ }^{12}$ Starting, therefore, with an examination of the significance of ethos to early modern English rhetoric, this chapter traces it through a variety of prefaces, forewords, and dedications of translations of the period. My aim is to demonstrate that the categories of ethos, as understood and applied by early modern English translators, are at once historically relevant and critically fruitful when it comes to examining the discursive metamorphoses of the translating self — and its complex relations to patrons, publishers, peers, and readers in the early age of print.

\footnotetext{
${ }^{11}$ McCabe, 'Ungainefull Arte', p. 73.

${ }^{12}$ See on this Warren Boutcher, 'The Renaissance', in Peter France (ed.), The Oxford Guide to English Literature in Translation (Oxford: Oxford University Press, 2000), pp. 45-55; Massimiliano Morini, Tudor Translation in Theory and Practice (Farnham: Ashgate, 2006). The vast majority of instances in which the concept of ethos has been applied to the analysis of translation discourse is found in studies of contemporary translation. This is arguably due to the recent influence of Ruth Amossy’s and Dominique Maingueneau's work in discourse analysis, and more specifically, on the discursive construction of authorial figures (“figures d'auteur"), a trend that ultimately derives from Chaim Perelman's "new rhetoric". See in particular Ruth Amossy (ed.), Images de soi dans le discours. La construction de l'ethos, (Lausanne: Delachaux and Niestlé, 1999), and Dominique Maingueneau, 'Ethos, scénographie, incorporation', in the same volume, pp. 75-100. I briefly address this issue in '(Auto-) portraits de l'auteur en traducteur: autorité horatienne et ethos du traducteur en Angleterre au XVIIe siècle', Camenae 17 (2015): pp. $1-15$.
} 


\section{Trust and Proof: Rhetorical Ethos in Early Modern England}

In classical rhetoric, the notion of ethos $(\tilde{\eta} \theta o \varsigma)$ refers to the character of the speaker as discursively constructed to the specific end of persuasion. It is first introduced by Aristotle in book I of his treatise on Rhetoric, as he distinguishes between three kinds of proof, or three main ways of convincing one's audience:

The first depends upon the personal character of the speaker [ethos]; the second upon putting the audience into a certain frame of mind [pathos]; the third on the proof, or apparent proof, provided by the words of the speech itself [logos]. ${ }^{13}$

Not only does ethos come first in Aristotle's triad, but it is defined as "almost the most effective means of persuasion". 14 The reasons for and means of establishing a convincing ethos are further discussed in book II of the Rhetoric, where the importance of establishing a trustworthy character is particularly emphasised:

The orator must not only try to make the argument of his speech demonstrative and worthy of belief; he must make his own character look right and put his hearers, who are to decide, into the right frame of mind. . . It adds much to an orator's influence that his own character should look right and that he should be

\footnotetext{
${ }^{13}$ Aristotle, Rhetoric, trans. W. Rhys Roberts (New York: Dover, 2004), II.1, 7.

${ }^{14}$ Aristotle, Rhetoric, II.1, 7.
} 
thought to entertain the right feelings toward his hearers; and also that his hearers themselves should be in just the right frame of mind. ${ }^{15}$

So as to convince his audience that he is worthy of belief, Aristotle continues, the orator must in turn demonstrate that he possesses three key qualities. These are specified as good sense, virtue, and goodwill. These three elements, he notes, "induce us to believe a thing apart from any proof of it"; and "anyone who is thought to have all three of these good qualities will inspire trust in his audience" ${ }^{16}$ The effectiveness of establishing a good ethos is finally discussed in book III of the Rhetoric, in an influential passage concerning prefaces where Aristotle lists the speakers' character as one of the factors that may win the audience's favour and dispel their natural prejudice against prefatorial remarks. The three other strategies are: appealing to the hearer's feelings; showing one's cause to be important; pitting the audience against one's own opponents. ${ }^{17}$

\section{Ethos in Humanist Education and Manuals of Rhetoric}

Interest in Aristotle's Rhetoric seems to have emerged among English university circles in the 1530s. The study of Aristotle developed relatively slowly in comparison to that of Latin rhetoric. However, the treatise was part of the Bachelor of Arts curriculum at Oxford in the 1560s, and Peter Mack notes that it regularly shows up in inventories of

\footnotetext{
${ }^{15}$ Aristotle, Rhetoric, II.1, 59.

${ }^{16}$ Aristotle, Rhetoric, II.1, 60.

${ }^{17}$ Aristotle, Rhetoric, III.14, 146.
} 
books owned by Oxford students. ${ }^{18}$ From 1572 to 1578 , John Rainolds, then lecturer of Greek at Corpus Christi, gave a famous course of lectures on the Rhetoric, in which he relays Aristotle's emphasis on ethos as the most effective means of persuasion. ${ }^{19}$ Not surprisingly, given Rainolds's own activities as a churchman and an influential preacher at Oxford, there is a definite Christian slant to his reading of the notion of character. ${ }^{20}$ Yet Rainolds also makes clear from his inaugural lecture that studying Aristotle's Rhetorics will help speakers to build judgment of character - a quality needed at once, in order to present a creditable figure, and to put one's audience "in the right frame of mind".

Significantly, Rainolds defines ethos by way of the Ciceronian notion of decorum; indeed, one cannot overemphasise the mediating role played by Latin rhetoric in the early modern reception of the concept. ${ }^{21}$ Although there is no exact Latin equivalent to the greek word, $\tilde{\eta} \theta 0 \varsigma$, the notion is discussed at length in Cicero's works, as well as in Quintilian's Institutio oratoria and in the Rhetorica Ad Herennium —all of which formed

${ }^{18}$ See Peter Mack, 'The Classics in Humanism, Education, and Scholarship', in The Oxford History of Classical Reception in English Literature (5 vols., Oxford: Oxford University Press, 2012-), II, pp. 29-55, at 41-42; see also Peter Mack, 'Classical Rhetoric in English', in The Oxford History of Classical Reception in English Literature (5 vols., Oxford: Oxford University Press, 2012), II, pp. 75-86; Peter Mack, A History of Renaissance Rhetoric 1380-1620 (Oxford: Oxford University Press, 2011), pp. 13-32; and Peter Mack, Elizabethan Rhetoric: Theory and Practice (Cambridge: Cambridge University Press, 2002), pp. $11-75$.

${ }^{19}$ John Rainolds, John Rainolds's Lectures on Aristotle's Rhetoric, ed. and trans. Lawrence D. Green (Newark: University of Delaware Press, 1986); see especially Green’s introduction, pp. 66-67.

${ }^{20}$ Rainolds, John Rainolds's Lectures, p. 67. See also Mack, Elizabethan Rhetoric, p. 53.

${ }^{21}$ Rainolds, John Rainolds's Lectures, 66; on the mediation of Latin Rhetoric, see Mack, A History of Renaissance Rhetoric, p. 25 and passim, and Skinner, Reason and Rhetoric, pp. 128-131. 
the basis of humanist rhetorical training, from grammar school onwards. In De inventione, for instance, Cicero rehearses Aristotle's discussion of prefaces, and identifies the character of the speaker (proof ab nostra) as one of the four ways in which the orator may secure his audience's goodwill (the other three being identified as ab judicum persona, a causa, and ab adversariorum). ${ }^{22}$ In De oratore, Cicero's description of the ideal orator converges with Aristotle's emphasis on good sense, virtue, and goodwillwith an additional stress on the social, public aspects of the speaker's character. ${ }^{23}$ In Quintilian and the Ad Herennium, ethos is specifically discussed as a key strategy in the opening part of a speech, the exordium. Quintilian notes that the speaker's reputation as a "good man" (vir bonus) will carry the strongest weight, before adding that a show of modesty will also win the "silent support" of the audience. ${ }^{24}$ The Ad Herennium offers similar recommendations, besides developing Aristotle's intimation that the speaker's character is partly constructed as a projection of the audience's own sense of self. ${ }^{25}$ It

\footnotetext{
${ }^{22}$ Cicero, On Invention; Best Kind of Orator; Topics, trans. H. M. Hubbell (Cambridge MA: Harvard University Press, 2014), pp. 44-45.

${ }^{23}$ Cicero, On the Orator, trans. E. W. Sutton, (2 vols., Cambridge MA: Harvard University Press, 2014), I, pp. 326-329, at p. 327; see also the analysis by Wendy Olmsted, Rhetoric: An Historical Introduction (Malden: Blackwell, 2006), pp. 29-30.

${ }^{24}$ Quintilian, The 'Institutio oratoria' of Quintilian, trans. H. Edgeworth Butler (4 vols., Cambridge MA: Harvard University Press, 1977), I, pp. 10-13, at p. 11.

25 "We shall secure goodwill by praising our services without arrogance and revealing our past conduct toward the republic, or toward our parents, friends, or the audience": Cicero, Rhetorica Ad Herennium trans. H. Caplan (Cambridge MA: Harvard University Press, 2014), pp. 14-15, and pp. 16-17.
} 
also elaborates on the fourth of Aristotle's prefatorial "remedies", noting that that the speaker's image may benefit from a negative perception of his enemies' own character. ${ }^{26}$

The study of Aristotle's Rhetoric itself was arguably limited to the universities, or to privately educated elites - the first printed translation of the treatise into English, for instance, was that prepared by Thomas Hobbes for his pupil, the future Earl of Cavendish. ${ }^{27}$ Yet it is to be expected that early modern translators would have been familiar with Cicero, Quintilian, the Ad Herennium, and Hermogenes's On Style, all of which were staple reading in the humanist curriculum. ${ }^{28}$ Their recommendations for establishing a successful ethos were further relayed by vernacular manuals such as Thomas Wilson's influential Arte of Rhetorique (1553). In this treatise, which in many ways represents a translation of the classical canon, Wilson devotes a full section to the

\footnotetext{
${ }^{26}$ Cicero, Ad Herennium, I.5, 15. Skinner, in Reason and Rhetoric, p. 131 notes that ethos is also discussed as one of the 'ideas' in Hermogenes's treatise On Style, which exerted significant influence on early modern English rhetoric. Like his Latin counterparts, Hermogenes highlights the importance of simplicity, sweetness, subtlety, and modesty to convey a trustworthy ethos, and thus gain influence over one's audience.

${ }^{27}$ A briefe of the art of rhetorique Containing in substance all that Aristotle hath written in his three bookes of that subject, except onely what is not applicable to the English tongue (London: Tho. Cotes, for Andrew Crook, [1637]).

${ }^{28}$ Arthur F. Kinney has also noted that students at Merchant Taylors', Mulcaster's Humanist school, usually read Aristotle's Rhetoric in Latin or English versions—-see Albert Charles Hamilton (ed.), The Spenser Encyclopedia (Toronto: University of Toronto Press, 1990), p. 553. Women, of course, could only access classical texts through private tutoring.
} 
exordium, in which he brings together the main tenets of classical theory. ${ }^{29} \mathrm{He}$ starts by detailing the four means of "getting the good willes of our hearers", as inherited from Aristotle and Cicero. ${ }^{30}$ More specifically, Wilson continues, we may make a good first impression on an audience if we are able to praise ourselves and advertise our public achievements while avoiding ostentation: "modestly declare our bounden dueties, and declare our service doen, without all suspiscion of vaunting". ${ }^{31}$ We should also establish our private virtue "in helping our frendes, kysfolke and poor neighbours". And finally, we should demonstrate, "without all ostentacioun, aswell our good willes towards the juges there, as also pleasures doen for them in tymes paste". ${ }^{32}$ Wilson also paraphrases the Ad Herennium where he points that it may be useful to speak of one's detractors in such a way "that the hearers shall either hate to heare of them, or outerly envy them, or altogether despise them"; to flatter one's audience by appealing to their public persona; to convince them of the worthiness of one's cause. ${ }^{33}$

Besides Wilson's general directions for successful ethos-building, early modern translators would have encountered more detailed resources in a number of other manuals.

\footnotetext{
${ }^{29}$ Mack, Elizabethan Rhetoric; also Jenny C. Mann's exciting study of the relationship of vernacular rhetoric to classical precedents in Outlaw Rhetoric: Figuring Vernacular Eloquence in Shakespeare's England (Ithaca: Cornell University Press, 2012). Thomas Sloane ('Wilson, Thomas', in Hamilton, The Spenser Encyclopedia, p. 728) effectively calls Wilson's treatise "an essay in ethos".

30 "either beginning to speake of our selves, or els of our adversaries, or els of the people, and company present, or last of all, if we begin with the matter itself': Thomas Wilson, The Arte of Rhetorique (London:

R. Grafton, 1553), fol. $56^{\mathrm{r}-\mathrm{v}}$.

${ }^{31}$ Wilson, The Arte of Rhetorique, fol. $56^{\mathrm{v}}$.

${ }^{32}$ Wilson, The Arte of Rhetorique, fol. $56^{\mathrm{v}}$.

${ }^{33}$ Wilson, The Arte of Rhetorique, fols. $56^{\mathrm{v}}-57^{\mathrm{r}}$.
} 
For example, among the rhetorical figures listed in Henry Peacham's popular Garden of Eloquence (first published in 1577), some are specifically designed to make one's character "look right". The figure of Philophronesis, for instance (or Benevolentia, as Peacham glosses), is one of calculated modesty, of "gentle speech, faire promises, and humble submission" before a powerful adversary. ${ }^{34}$ That of Parrhesia suggests defensive humility: "the Orator speaking before those whom he . . ought to reverence ... preventeth the displeasure and offence that might be taken, as by craving pardon afore hand". ${ }^{35}$ Finally, the figure of Eucharistia relies on an elaborate display of thankfulness: "A forme of speech by which the speaker geveth thankes for benefits received .... Sometime it is joined with a confession of the unablenesse of the receiver to requite the giver". 36

\section{Ethos and the Early Modern Formal Epistle}

The principles and figures detailed above have been shown to pervade early modern English literary production. For instance, Aristotle's Rhetoric represented an important source for Philip Sidney's Defence of Poesie, and there are traces of a manuscript translation of books I and II of the Rhetoric, also by Sidney, circulating among his close

\footnotetext{
${ }^{34}$ Henry Peacham, The Garden of Eloquence Conteining the most Excellent Ornaments, Exornations, Lightes, flowers, and formes of speech, commonly called the Figures of Rhetorike (London: Richard Field, 1593), pp. 96-97.

${ }^{35}$ Peacham, The Garden of Eloquence, p. 113.

${ }^{36}$ Peacham, The Garden of Eloquence, p. 101.
} 
circle in the $1580 \mathrm{~s} .{ }^{37}$ Ben Jonson is also known to have relied on the three main components of a successful ethos - that is, good sense, virtue, and goodwill - in order to construct his literary persona. ${ }^{38}$ Of more direct importance to us, however, is the way these categories — and the rhetorical tropes that accompany them — shaped the genre of the prefatory epistle. In early modern theory and practice, formal epistles were generally considered as forms of orations. As such, they fell under the categories of classical rhetoric. A revealing example is the epistle "To the Reader" that opens Nicholas Grimald's seminal translation of Cicero's De officiis (1556), where the Oxford scholar displays his ability to imitate Ciceronian oratory, from exordium to peroration. ${ }^{39}$ But the point had already been clearly made in Desiderius Erasmus's De conscribendis epistolis (1522), a major source for English letter-writing manuals. ${ }^{40}$

\footnotetext{
${ }^{37}$ See for example Travis Curtright, 'Sidney's Defense of Poetry: Ethos and the Ideas', Ben Jonson Journal 10 (2003), pp. 101-115. On the lost manuscript translation of books I and II of the Rhetoric, see H. R. Woudhuysen, Sir Philip Sidney and the Circulation of Manuscripts, 1558-1640 (Oxford: Clarendon Press, 1996), p. 236.

${ }^{38}$ See Blaine, 'Envy, Eunoia and Ethos', and Belle, '(Auto-) portraits de l'auteur'. See also the classical study by Sister Miriam Joseph, Shakespeare's Use of the Arts of Language (Philadelphia: Paul Dry, 2005 [1947]), who traces the categories of ethos through the works of Shakespeare, showing how they help shape and sometimes even self-reflectively stage the audience's perception of various characters.

${ }^{39}$ Marcus Tullius Ciceroes thre bokes of duties to Marcus his sonne, turned out of latine into english, by Nicholas Grimalde (London: Tottel, 1556).

${ }^{40}$ Erasmus does, however, distinguish between formal epistles, which are modelled on the genres of Ciceronian oratory, and the 'familiar' kind of letters addressed to closer friends and family members (although they engage a number of similar strategies).
} 
John Day's English Secretarie (first published in 1586) thus aligns the various kinds of letters, and their constitutive parts, with those of the Ciceronian oration. His discussion of the exordium refers again to the four ways of winning the benevolence of the addressee - the first being the characterisation of the writer's self ( $a b$ nostra, or "our selves"). ${ }^{41}$ The issue of character is more specifically broached in the introductory remarks on decorum: Day notes that, not only should the writer consider the social situation of the addressee, but "the matter of everie writing should still be measured according to the writers appearance, credit, or worthiness". ${ }^{42}$ It is also developed at some length in the section on the "petitory epistle", where Day insists on the importance of "a more then ordinarie bashfulness". ${ }^{43}$ If we chose to frame the exordium around the presentation "of owre owne persons" (ab nostra), he notes,

then shall we lay open, with what great expectation and regard we do in our conceits entertaine the desertes and worthiness of [the addressee], modestly pr[o]ferring what in favor of him, and common and equall love or regard hath passed between us. ${ }^{44}$

\footnotetext{
${ }^{41}$ John Day, The English Secretary, or Methode of writing of Epistles and Letters . . Now newly revised and in many parts corrected and amended (London: P. S. for C. Burbie, 1599), p. 11; and more generally the whole chapter 2, "Of the habite and parts of an epistle", pp. 3-11.

42 Day, The English Secretary, p. 4.

${ }^{43}$ Day, The English Secretary, p. 92.

${ }^{44}$ Day, The English Secretary, p. 92.
} 
Recent studies of epistolary practices have shown the pivotal role played by the dynamic representation of self and other, of writer and addressee, of petitioner and patron in early modern letter-writing. In epistles ranging from the humanist exchanges analysed by Judith Henderson to Frank Wigham's examples of suitors' letters at Elizabeth's court, the art of modest self-display was of paramount importance, as was the careful engineering of social relationships and hierarchies. ${ }^{45}$ Successful letter-writers thus proved particularly adroit at establishing a reciprocal dynamics where favours received became proof, at once of the magnanimity of the granter, and of the petitor's personal worth. Such displays of mutual interest were, of course, central to court culture, and to the economy of patronage. As is well known, the early modern rhetoric of friendship functioned according to the same principles, especially as the notion of "friend" was then constructed on a social, rather than personal basis: that of favours granted and received, both social and material. ${ }^{46}$ And as McCabe reminds us, early modern English dedications are full of declarations of approximate or imagined friendships, among other forms of "fictive kinship"; all were constructed to the specific ends of establishing one's social and literary status, as well as ensuring the reception of one's writings. ${ }^{47}$

\footnotetext{
${ }^{45}$ Judith Rice Henderson, 'Humanist Letter-Writing: Private Conversation or Public Forum?', in Todt Van Hoot, Jan Papy, and Gilbert Tournoy (eds.), Self-presentation and Social Identification: The Rhetoric and Pragmatics of Letter Writing in Early Modern Times (Leuven: Leuven University Press, 2002), pp. 17-38; Frank Wigham, ‘The Rhetoric of Elizabethan Suitors' Letters’, PMLA 96 (1981), pp. 864-882.

${ }^{46}$ See Richard S. Peterson, Imitation and Praise in the Poetry of Ben Jonson (Farnham: Ashgate, 2011 [1981]), p. 159 and passim, and, more recently, McCabe, 'Ungainefull Arte', p. 16 and passim.

${ }^{47}$ The name of the powerful 'friend' thus serves as a social marker, as well as a warrant against the perceived vulgarity of submitting one's name and writings to the commercial pressures of the book market.
} 
The complex reception of Aristotle's notion of ethos in early modern England carries important implications for the fashioning of the writing self-and the translating self-in liminal discourse. Firstly, the rhetoric of self-presentation reveals the complex interplay between conventional, even expected forms of discourse, and the social and cultural necessity of convincing patrons and readers of the ingenuity of one's intentions. In translation discourse, this paradox lies at the heart of the traditional emphasis on fidelity: while translators routinely declare that they were not faithful to the word (nec verbum verbo etc.), nonetheless they cast themselves as trustworthy mediators between the original author and the "gentle" or "courteous" readers of the translated text.

Secondly, in the early modern context of the development of print, the dialogic relationship between private and public in the fashioning of the early modern self is highlighted by the vulgarising nature of the act of translation. Dunn notes, for instance, how the "prefatory authority" displayed in early modern liminal discourse is marked an unresolved tension between the public, social, and conventional persona constructed by rhetorical discourse, and the emerging individuality of the Protestant self. ${ }^{48}$ Such issues obviously come to the forefront in the religious and political enterprise of early modern Bible translation. They also extend, more generally, to the intertwined phenomena of translation and print production. Both indeed engage a complex interplay between individual agency and public perception, between personal mediation (linguistic, social,

\footnotetext{
${ }^{48}$ Dunn, Pretexts of Authority, pp. 7-13.
} 
cultural) and the means of material reproduction, diffusion, and reception that underlie the very notion of "print authorship". 49

\section{Fashioning the Translator: Recurring Tropes, Specific Strategies}

If one is to consider translation discourse in the light of early modern rhetoric, the question that arises is whether it is possible to identify translation-specific rhetorical tropes — or at least, translation-specific uses of the rhetorical commonplaces established by the theory and practice of ethos-building in prefatory discourse. Certainly, if, following Aristotle, the speaker's posture in a preface is defensive by nature, that of the translator's is doubly so. This is due, on the one hand, to the "status anxiety" deriving from the perceived secondary rank of translations, "deliver'd at second hand" ${ }^{50}$ It is due, on the other hand, to the apologetic stance inherited from centuries of translation discourse, beginning with Cicero's opening remarks to his translations from the Greek, and Jerome's Epistle to Pammachius.

\section{The Double-Edged Trope of Humility}

Theerefore the first trope to be examined here is that of humility, which obviously represents the most famous aspect of the translation preface, as well as an outstanding

\footnotetext{
${ }^{49}$ For an example of the interplay between public and private address in dedications of Tudor translations, see Fred Schurink, 'Print, Patronage, and Occasion: Translations of Plutarch's "Moralia" in Tudor England', The Yearbook of English Studies 38 (2008), pp. 86-101.

${ }^{50}$ As (in)famously argued by John Florio in the dedicatory epistle of his 1603 translation of Montaigne's The essayes or morall, politike and millitarie discourses of Lord Michaell de Montaigne. ... The first booke (London: Edward Blount, 1603), fol. A2 ${ }^{\mathrm{r}}$.
} 
illustration of the kinds of calculated modesty recommended in rhetorical treatises, from Aristotle to Wilson's Art of Rhetoric. Consider, for example, the opening of Miles Coverdale's Prologue to the 1535 Bible ... Faithfully Translated in to English. The project was one of momentous religious and political significance, as highlighted in the dedicatory epistle "Unto the most victorious Prynce, and oure most gracious soveraigne Lorde, kynge Henry", whose full titles, prominently displayed upon the page, serve as warrant of the translator's relative authority as King Henry VIII's “humble subjecte and daylye oratoure". The relationship is significantly illustrated in the last page of the dedication, where Coverdale's signature is printed in small font at the very bottom of the page, while the running title at the top advertises the royal addressee: "Unto the Kynges hyghnesse". ${ }^{51}$ Further, it appears that the construction of the translating self was also of major importance when addressing the general "Christian" readership:

Considerynge how excellent knowledge and lernynge an interpreter of Scripture oughte to have in the tongues, and pondering also my own insufficiency therin, and how weak I am to perform the office of a translator, I was the more loath to meddle with this work. Notwithstanding, when I considered how great pity it was that we would want it for so long, and called to my rememberaunce the adversite ... by reason of [which] it could not so soone have bene brought to an ende, as

\footnotetext{
${ }^{51}$ Biblia the Byble, that is, the holy Scrypture of the Olde and New Testament, faithfully translated in to Englyshe (Southwark: J. Nycolson, 1535), fols. ii $^{\mathrm{r}}$ and ${ }^{\mathrm{iiii}}{ }^{\mathrm{r}}$.
} 
oure most prosperous nacyon would fayne have had it; these and other reasonable causes considered, I was the more bold to take it in hand. ${ }^{52}$

In this prologue, fashioned as a direct address from "Miles Coverdale Unto the Christian reader", all of the recommendations of classical rhetoric have been followed. Coverdale's opening follows the four parts of the classical exordium. He first presents his own character, before evoking the obstacles ("adversites") that enemies of Bible translation had raised over time, and emphasising the importance of the task at hand, as well as its benefits for "our most prosperous nacyon". Blending Christian humility tropes, such as the conjunction of "weak" and "bold" (which is clearly reminiscent of St. Paul's epistles), with the specific recommendations inherited form Quintilian and Cicero, he declares his "insufficiency" in the matter, and expresses reluctance towards the task at hand: "loth to meddle with this work". Through all his protestations, however, Coverdale conveys the three main elements of Aristotelian ethos. His show of modesty is evidently designed to cast him as a virtuous character. By exposing the "reasonable causes" motivating his translation, and his awareness of the task of the Bible translator, he comes across as responsible and considerate. Finally, his "boldness" in attempting the translation is explained as zeal for the spiritual welfare of his readers, and therefore a token his good intentions: "therefore wh[e]n I was instantly required, though I coulde not do so well as I wolde, I thought it yet my dewtye to do my best, and that with a good wyll". ${ }^{53}$ With such a display of rhetorical devices, Coverdale impresses upon his "Christian" readers his

\footnotetext{
${ }^{52}$ Biblia the Byble, sig. Hiiii

${ }^{53}$ Biblia the Byble sig. Wiiii" ${ }^{\mathrm{v}}$.
} 
trustworthiness as a "weak", yet "bold" translator of the Bible, while also reminding them of his position as the King's "daylye oratour", versed in classical rhetoric, and capable of writing long, flowing periods in the Ciceronian style.

A similar instance of self-assertion disguised as humility can be observed where translators ask their readers' forgiveness for turning the Latin or Greek ornaments of the original into a plain English coat — only to attack those who favour instead a more florid, foreign style, or resort to controversial neologisms. ${ }^{54}$ Such is the case in John Dolman's preface to his translations of Cicero's Tusculan Disputations (1561). Dolman defends his "simple" style against those who "cloak their ignorance in so-called "inkhorn terms", as he notes:

Then, for mine own translation: forasmuche as it must of necessity be . . more simple then the stile of Tullie ... I had rather to be partener of the favour, due to simplicity and playneness ... By which my plainnes, without counterfaite eloquence, ... I have thereby escaped, the just reproofe, that they deserve, whiche thinke, to cloke their ignoraunce, wyth inkehorne termes. ${ }^{55}$

\footnotetext{
${ }^{54}$ On the sartorial metaphor in translation discourse and its origins in classical rhetoric, see Frederick M. Rener, Interpretatio: Language and Translation from Cicero to Tytler (Amsterdam: Rodopi, 1989), p. 23, and Massimiliano Morini, Tudor Translation in Theory and Practice (Aldershot: Ashgate, 2006), pp. 37-41.

${ }^{55}$ Those fyue questions, which Marke Tullye Cicero disputed in his manor of Tusculanum ... Englished by John Dolman (London: Thomas Marshe, 1561), “To the Reader”, fol. [Av] $]^{\mathrm{r}}$.
} 
While resorting to the conventional deprecation of the translation's "simple" style, thus assuring readers of his humility, Dolman manages to praise this very plainness as a sign of competence ("escaped ... the just reproofe etc.") and of virtue ("without counterfaite eloquence").

Such strategies of double-edged apology and defence are precisely those which John Harington simultaneously debunks and exploits in his mock-refusal of the modesty topos. In the famous "Brief apologie" that prefaces his 1591 translation of Orlando Furioso, Harington teasingly declares that:

Certainly if I shold confesse or rather professe, that my verse is unartificiall, the stile rude, the phrase barbarous, the meeter unpleasant, many more would believe it to be so, than would imagine that I thought them so. ${ }^{56}$

In what reads as a perfect example of courtly sprezzatura, Harington turns the rhetoric of prefatory "confessions" upon its head, wittily exposing its artificiality and its potential dangers. The experienced courtier — here playfully presented as a naïve reader taking the translator at the foot of the letter - could very well turn the orator's tricks against him (or her) if he were to wilfully ignore the social and rhetorical conventions of the genre. Such wilfulness would annul the discursive bases on which the orator's and the public's "beliefs" are supposedly built, and reveal the speaker's persona to be but a mask.

\section{The Trope of Usefulness and its Relation to Skill}

\footnotetext{
${ }^{56}$ Orlando Furioso in English heroical verse, by John Harington (London: Richard Field, 1591), fol. [A7]
} 
Another commonplace that bears particular significance in translator's prefaces is that of the usefulness of translation. A major tenet in humanist discourse, Horace's "utile dulci" topos is employed in almost every early modern prologue or preface, sometimes even appearing on printed title pages to promise potential readers both profit and pleasure in their purchase. ${ }^{57}$ This most common of commonplaces is, however, sometimes put to significant use by translators. Falling at first sight under the category of logos, as an argument in favour of translation, the trope also supports the speaker's self-presentation as a person of virtue and goodwill. Arthur Golding thus professes at once his personal and public merits by declaring that he has translated The Histories of Trogus Pompeius (1564),

as well for th[e] avoyding of Idlenes the mother and nourisher of all vice, and also for the zeale I beare to this my native countrie, desyrous to gratifie yea and to profite such as have not understandinge in the Latin tong yf I coulde. ${ }^{58}$

\footnotetext{
${ }^{57}$ The title page of Arthur Golding's 1564 translation of the Histories of Trogus Pompeius thus promises readers "great plentie of moste delectable hystories, and notable examples, worthie not onelie to be read but also to be embraced and followed of all menne": Thabridgment of the histories of Trogus Pompeius, collected and wrytten in the Laten tonge, by the famous historiographer Iustine, and translated into English by Arthur Goldyng (London: Thomas Marshe, 1564). For a more detailed study of the role of title pages in the fashioning of early modern translations, see Brenda Hosington, 'English Printers and the Nature of the Translated Title-page', in Thresholds of Translation (forthcoming, 2017).

${ }^{58}$ Thabridgment of the histories of Trogus Pompeius, fol. [*vi] ${ }^{\mathrm{r}}$.
} 
In the epistle "To the Reader" prefacing her translation of Diego Ortuñez de Calahorra's Mirror of Princely Deedes and Knightehood (1578), Margaret Tyler similarly promises her reader "profit and delight". She declares herself satisfied "if [her] travaile in Englishing this Author may bring thee [i.e. the reader] to a liking of the vertues herein commended", and proceeds to paraphrase Horace: "he hath ever borne the price which could season such delights with some profitable learning". ${ }^{59}$ In Tyler's case, the reference to Horace plays a special role. Tyler is at pains to prove her fitness, as a woman, to translate works of chivalry, a genre apparently more suited to male readers and translators. Consequently the Horatian citation serves to establish her virtue and goodwill; but it also advertises her awareness of the conventions of the prefatorial genre, and her proficiency in its established rhetoric. Even as she vindicates a woman's ability to deal with both the linguistic aspects of the text and its subject matter, she demonstrates that she is just as skilled in the rhetorical strategies commonly deployed in order to establish a convincing ethos.

Tyler's self-portrayal as a humble, hard-working, competent translator is in fact constructed through an extremely efficient use of the four classical "remedial" strategies of the exordium. She first praises the value of the original (a causa). She then establishes her own character ( $a b$ nostra), both humble and fearless: "As for well deserving my selfe that way, I neither bend my selfe therto nor yet feare the speach of people if I be found backward". Tyler continues by responding to her "ill-willers" (ab adversariorum). and by

${ }^{59}$ The Mirrour of Princely deedes and Knighthood . . Now newly Translated out of Spanish into our vulgar English tongue, by M[argaret] T[yler] (London: T. East, 1578), fol. [Aiii] ${ }^{\mathrm{r}-\mathrm{v}}$. See also Joyce Boro's edition: Margaret Tyler, Mirror of Princely Deeds and Knighthood, ed. Joyce Boro (London: MHRA, 2014), and the "Introduction" in particular, for a full discussion of the preface. 
appealing to her readers' desire (ab judicum persona) for both "delights" and "profitable learning". Finally, she ends her preface by commending herself to her public's "good favour" and "speciall regard", in a striking example of the figure of parrhesia (or preventive apology):

But of these two points gentle reader I thought to give thee warning, least perhaps understanding of my name and yeares, thou mightiest be carried into a wrong suspect of my boldnesse and rashnesse, fro[m] which I would gladly free my selfe by this plaine excuse $\ldots{ }^{60}$

Significantly, the various parts of the epistle are identified in the margins of the printed edition, in such a way that readers could not but recognise them as the classic rhetorical components of a preface, or formal epistle. Tyler's (or her publisher, Thomas East's) marginalia thus signal "The commendation of the storie", and identify Tyler's selfpresentation strategies by noting "That a woman maye write of warre" ${ }^{61}$ Tyler's responses to her "ill-willers" are summed up by the next two marginal notes, "That you maie not write of divinitie", and "That you meant to make a common benefit of your paines". ${ }^{62}$ A further note highlights "the use and profit of this Spanish translation" for the reader (proof ab judicum persona), while the rhetorical nature of the preface is finally underscored by the last marginal indication: "The conclusion". ${ }^{63}$

\footnotetext{
${ }^{60}$ Tyler, The Mirrour of Princely deedes, fol. [Aiii] ${ }^{\mathrm{v}}$.

${ }^{61}$ Tyler, The Mirrour of Princely deedes, fol. [Aiii] ${ }^{\mathrm{r}}$.

${ }^{62}$ Tyler, The Mirrour of Princely deedes, fol. [Aiii] ${ }^{\mathrm{v}}$.

${ }^{63}$ Tyler, The Mirrour of Princely deedes, fol. [Aiii] ${ }^{\mathrm{v}}$.
} 
Together the few foregoing examples offer a prime illustration of the selfreflective nature of prefatorial discourse: the strategies employed to construct one's character also serve to demonstrate one's skill at the very task of ethos-building. Yet the dialogic relationship between self and other is also crucial in the creation of rhetorical ethos. In the case of translations, the mirroring dynamics established between the speaker, his or her audience, and potential opponents is extended to yet another figure in the fashioning of the translator's persona - that is, the author of the translated text. For one of the advantages of praising the virtues of one's author (beyond their usefulness as proof of the worthiness of one's cause) is that the praise may easily be extended to oneself.

\section{Mirroring Dynamics and Tropes of Praise}

In the preface to the first tome of his History of the World, Philemon Holland portrays Pliny the Elder, the author of the encyclopaedic Historia naturalis, as an exceptionally hard-working scholar, of unequal zeal in the translation of Greek knowledge, and concerned with "the generall good of mankind". ${ }^{64}$ This characterisation is exactly mirrored in Holland's own self-presentation strategies; it exemplifies what André Lefevere would have recognised as an unashamed transfer of cultural capital. ${ }^{65}$ Holland

\footnotetext{
${ }^{64}$ The Historie of the World, commonly called, the Natural Historie of C. Plinius Secundus. Translated into English by Philemon Holland, Doctor of Physicke. The First Tome (London: Adam Islip, 1601), fol. $2^{\mathrm{v}}$. ${ }^{65}$ See André Lefevere, 'Translation Practice(s) and the Circulation of Cultural Capital: Some English Aeneids', in Susan Bassnett and André Lefevere, Constructing Cultures: Essays in Literary Translation (Clevedon: Multilingual Matters, 1998), pp. 41-46. For a full examination of Holland's paratextual strategies, see Marie-Alice Belle, “'Mysteries Divulged': Philemon Holland's Paratexts and the Translation of Pliny's Natural History in Early Modern England', Meta 61 (2016), pp. 70-86.
} 
explicitly frames his project as a continuation of Pliny the Elder's "precedent", since "the author himself . . . translated a good part thereof out of the Greek" ${ }^{66}$ The parallel is further exploited to establish Holland's concern for the common good: "my purpose especially is to profit and please the most ignorant (for whose sake Plinie also himself, as he professeth, compiled this worke)" ${ }^{67}$ In addition, Holland's professed admiration for Pliny's industry may be read as an oblique (modesty oblige) commentary on his own titanic task, and a way of positioning himself as a virtuous censor of modern indolence: "when I look back to the example of Plinie, I must of necessitie condemne both mine own sloth, and also reprove the supine negligence of these daies", ${ }^{6}$

Such transfers of authority and good character were obviously expected to be recognised and accepted as straightforward applications of the ancient argument of authority. They also participated in the humanist logic of translatio, according to which early modern translation projects were precisely modelled on the transfer of Greek knowledge to classical Rome. ${ }^{69}$ More complex, however, was the establishing of one's credibility against opponents; either opponents of translation in general, or those of one's specific project. Classical rhetoricians had indeed pointed to the difficulty of maintaining the audience's belief in one's own virtue and goodwill when showing opponents in a bad

\footnotetext{
${ }^{66}$ Holland, Historie, fol. $2^{\mathrm{v}}$.

${ }^{67}$ The Historie of the World, fol. Aiir.

${ }^{68}$ Holland, Historie, fol. $4^{\mathrm{r}}$.

${ }^{69}$ See for example Marcus Tullius Ciceroes, fol. [9ๆ V $]^{\mathrm{v}}$ : "These richesse, \& treasures of witt, and wisdome, as Cicero transported oute of Greece into Italie : so have I fetched from thence ; \& conveied them into England".
} 
light (hence potentially leaving oneself open to the charge of envy). ${ }^{70}$ The answer, for early modern English translators, often consisted in equating the defence of one's translation with pure patriotism. For example, those who objected to translation in general, or claimed that the English language was too scarce or "barbaric" to compete with the source text, were turned into the ridiculous figure of the inglese italianato, if not into straightforward enemies of the English nation. Such is the insinuation in George Pettie's sarcastic description of "some nice travelers who returne home with such quaesie stomackes, that nothyng wyll downe with them but Frenche, Italian, or Spanishe". ${ }^{71}$

An alternative strategy was to exploit the context of cultural competition among European countries by claiming that the book had already been translated into Italian, French, or even Spanish: surely one would not wish England to fall behind Continental rivals. Henry Parker, Lord Morley, declared that his 1555 translation of Petrarch's Trionfi had been motivated by his awareness of a French version circulating at the court of the French king, Francis I: "Which sayde book, when I sawe the coppye of it, I thougthe in my mynde, howe I beynge an Englyshe man, myght do aswell as the Frenche man", 72 Holland again, famous for his call to English translators "to triumph now over the Romans in subduing their literature under the dent of the English pen", also pitted his own endeavour against French and Italian precedents in unmistakeably competitive

\footnotetext{
${ }^{70}$ See Skinner, Reason and Rhetoric, p. 131, and Blaine, 'Envy, Eunoia and Ethos'.

${ }^{71}$ The ciuile conuersation of M. Steeuen Guazzo written first in Italian, and nowe translated out of French by George Pettie (London: R. Watkins, 1581), fol. iir ${ }^{\mathrm{r}}$.

${ }^{72}$ The tryumphes of Fraunces Petrarcke, translated out of Italian into English by Henrye Parker knyght, Lorde Morley (London: J. Cawood, ca. 1555), fol. Aiii ${ }^{\mathrm{r}}$.
} 
terms: "Are we the onely nation under earth unworthie to tast of such knowledge?". 73

By appealing to their readers' sense of virtue (either personal or national), translators relied on a dynamics of reciprocal recognition, in which the orator projects an idealised image of the audience, only to use it as a warrant of his or her own character. As observed above, this mirroring optics was an essential component of the economy of dedication and patronage. Notice, for example, how Mildred Cecil, one of the Cooke sisters renowned for their scholarship and proficiency in classical languages, adopts the traditional pose of gratitude and dependency, as she dedicates her manuscript translation of a sermon by the Church father, St. Basil, to her patroness, the "very noble and virtuous Duchess of Somerset”:

Like as poor debtors, most honourable and my very good lady, desiring to pay that their poverty keepeth back, and seeking honestly to may that they would, use for the continuance of their creditor's favour either to pay some small part to prolong the remanent or to intercede by friends to diminish the debt. ${ }^{74}$

Cecil clearly follows the directions relayed by early modern rhetorical treatises and letterwriting manuals, making ample use of the rhetorical figure of eucharistia. Her emphasis on her dedicatee's generosity thereby signals the value of her translation as a token of social exchange, which her patron's acceptance eventually validates. In this case, as Jaime Goodrich has shown, the translator's rhetorical stance addresses a context that was

\footnotetext{
${ }^{73}$ Holland, Historie . . The First Tome, fol. $2^{\mathrm{v}}$.

74 'An Homily or Sermon of St. Basil the Great', trans. Mildred Cecil, in Neil Rhodes, Gordon Kendal, and Louise Wilson (eds.), English Renaissance Translation Theory (London: MHRA, 2013), p. 243.
} 
extremely fraught for both translator and dedicatee. ${ }^{75}$ The years $1549-50$ were marked by the fall, and subsequent return to favour, of the Duke of Somerset, patron to Mildred Cecil's husband, William Cecil. On the one hand, William Cecil's allegiance to his patron had been seriously put to the test during the crisis. On the other, Anne Seymour, Duchess of Somerset, had often been blamed for her own husband's reckless ambition, and accused of having caused his disgrace. Following the reinstatement of the Duke, Mildred Cecil's gift of her manuscript translation, and her address to the Duchess, may be read as a way of advertising the renewed political alliance between both families. Yet as Goodrich notes, her "guarded" tone and her use of conventional rhetoric also signal that her gift may be somewhat loaded: her translation from the Greek subtly emphasizes St Basil's condemnation of secrecy and ambition, which "may have very well been read as a comment on the [Somersets'] private politicking" ${ }^{76}$

\section{Communities of Readers}

The practice of emblazoning patronage relationships in the margins of the text was carried over from manuscript culture to print — with the added publicity that the latter medium allowed. Hence a common way of simultaneously celebrating patrons and advertising one's connection to them was to have their coats of arms reproduced in the liminal pages of a book. ${ }^{77}$ In his 1567 edition of Horace his arte of poetrie, [E]pistles and Satyrs, Englished, and to the Earle of Ormounte by Tho. Drant addressed, Thomas Drant

\footnotetext{
${ }^{75}$ Jaime Goodrich, 'Early Modern Englishwomen as Translators of Political Literature’, PhD Thesis, Boston College, 2008, pp. 176-189.

${ }^{76}$ Goodrich, ‘Early Modern Englishwomen', p. 184.

${ }^{77}$ See McCabe, 'Ungainefull Arte', p. 93.
} 
puts this device to use with remarkable efficiency. Significantly, the edition includes a full-page display of the coat of arms of the Ormonds. But Drant also inserts on the facing page a Latin poem "on himself" ("De seipso"), in which he appropriates a line in Martial's Epigrams to remind himself that: "There will be no lack of Maecenases, as long as there are Virgils" ("Non deerunt Maecenates, sint (Dranta) Marones"). ${ }^{78}$ By casting Ormond as a new Maecenas, and himself as a new Horatian figure, Drant furthers the rhetoric of the dedication. His epistle to Ormond exploits almost ad nauseam the precedents of Horace and Maecenas, claiming, for instance, that: "Well was it for Horace that he was cherished by Maecenas ..., better was it for Maecenas that he cherished Horace" ${ }^{79}$ Of course, such a parallel was commonplace at the time. Yet in the margins of Drant's Horatian translation, it reactivates the dynamics of patronage and friendship long associated with the classical precedent. Moreover, with the translator's self-portrait "De seipso" directly facing the arms of the patron, the reader of the printed text is brought to witness, validate, and participate in the reciprocal rhetoric developed in Drant's dedicatory epistle, and in his punning poem "on himself" - a pun precisely intended for readers familiar with Horace, Martial, Virgil, and the "Maecenases" of the times.

For the most striking way in which translators in early modern England drew on their readers' sense of self to support their own stance was by casting the writing and

\footnotetext{
${ }^{78}$ Horace his arte of poetrie, [E]pistles and Satyrs Englished and to the Earle of Ormounte by Tho. Drant addressed (London: Thomas Marshe, 1567), fol. *ii ${ }^{\mathrm{V}}$. Martial, Epigrams 8.55.5, actually reads: "Sint Maecenates: non deerunt (Flacce) Marones", or "As long as there are Maecenases, there will be no lack of Virgils". Whereas Martial emphasises the crucial role of patronage, Drant significantly reverses the perspective, making the existence of patrons dependent on the skill of poets.

${ }^{79}$ Horace his arte of poetrie, fol. [*ii] ${ }^{\mathrm{v}}$.
} 
reading of translations as the shared activities of a select community of readers. The happy few sometimes belonged to the social or political elite. In 1555, Lord Morley remarked, for example, how his version of Petrarch's Triunfi was first read by none other than King Henry VIII, who "toke the worke verye thankefullye" and "marveled much" that he had translated the Latin poems "without help". ${ }^{80}$ Sometimes, these select communities were presented as intellectually superior: George Chapman pointedly addressed his 1598 Achilles Shield "To the Understander". His epistle "To the Reader" in his Seaven Bookes of the Iliades opens with the declaration "I suppose you to be no meare reader, since you intend to reade Homer". ${ }^{81}$ Other publications see the translator's select addressees cast as morally superior: Thomas Hawkins, a Catholic translator at the court of Henrietta Maria, declares in his 1625 translation of The Odes of Horace that he has censored some of the more "wanton" poems, against the wishes of the majority of common readers. These "looser strains" he leaves to those who are content to wade in the "troubled and muddy waters of sensuality", while his readers will instead "drinke goodnesse from these purer fountains" ${ }^{82}$

While each translators' underlying motivations may have varied (say, from political advancement to ideological and spiritual reform), such strategies of exclusivity all rely on the mirroring dynamics of ethos: the translator's self-image is constructed and validated by a flattering representation of the reader, with which the latter will readily

\footnotetext{
${ }^{80}$ The tryumphes of Fraunces Petrarcke, fol. Aiiir ${ }^{\mathrm{r}}$.

${ }^{81}$ Achilles shield Translated as the other seuen bookes of Homer, out of his eighteenth booke of Iliades (London: John Windet, 1598), fol. B1 ${ }^{\mathrm{v}}$; Seauen bookes of the Iliades of Homere, prince of poets, translated according to the Greeke (London: John Windet, 1598), fol. [A4] ${ }^{\mathrm{r}}$.

${ }^{82}$ Odes of Horace ... Selected and Translated by Sir T. H. (London: W. Lee, 1625), fol. A ${ }^{\mathrm{v}}$.
} 
identify. In the interlocked contexts of early modern translation and print culture, these strategies were of significant importance: they allowed translators to present themselves as benevolent mediators, through translation and print diffusion, for the "common good" of an expanding readership. At the same time they branded their works as valuable cultural products, worthy of the attention of patrons, and of the "gentle reader's" purchase.

By tracing the categories of rhetorical ethos through various examples of early modern English paratextual discourse, I have sought to demonstrate the pivotal importance of classical rhetoric, in its manifold early modern re-configurations, to the fashioning of the English translating self. While converging with the now well-established notion of "selffashioning”, and with more recent explorations of issues such as the translator's "visibility", or early modern English translation "habitus", a focus on the rhetoric of ethos has the advantage of relying on historically endogenous categories. ${ }^{83}$ The concept of ethos speaks to the specific, although complex, influence of ancient rhetoric on early modern English writing and translating cultures, and, more particularly, to the liminal genres of the preface and the dedication.

Reading translation prefaces and dedications according to classical and early modern prescriptions for successful self-presentation helps, in turn, to address the understudied relations between translation discourse and other instances of prefatorial or

\footnotetext{
${ }^{83}$ See Coldiron, 'Visibility Now'; on the notion of habitus and its application to early modern translation practices, see Goodrich, Faithful Translators, pp. 9-16.
} 
epistolary writing. Therefore, it makes possible identification of shared strategies, and more devices that prove specific to translation projects. The humility topos, as well as the feigned reluctance of printed authors, obviously belong to the common rhetorical field, but other strategies were clearly designed to promote translators as such. The most recognisable of all is the transfer of the author's constructed character onto the translator's self. A more intricate device is that exploiting the paradoxes of print authorship (and readership), by advertising printed translations both as a means of circulating texts and ideas, and as a token of exchange among a community of privileged readers.

The examples examined herein reveal the complex, often complementary relationship between the discursive strategies deployed by translators and the material features of their printed texts. In some instances, such as Coverdale's Bible, or Drant's translation of Horace, the choice of font, page layout, and visual paratexts contribute to the fashioning of the translator's persona. So do the marginal notes in Tyler's famous preface, because they highlight the rhetorical skill that underlies her address to the reader. Other case studies are needed in order to explore the connections between the means of self-presentation deployed in discursive paratexts and those evidenced in other visual or material features of early modern printed translations - and in order to identify the social, political, or religious issues at stake in such self-defining acts. ${ }^{84}$ Yet by tracing the

\footnotetext{
${ }^{84}$ On the interplay between translation discourse and visual aspects of translation paratexts, see in particular Anne E. B. Coldiron, 'Form(e)s of Transnationhood: The Case of John Wolfe's Trilingual Courtier', Renaissance Studies 29 (2015), pp. 103-124; Armstrong's 'Coding Continental', as well as her earlier study, 'Print, Paratext, and a Seventeenth-Century Sammelband: Boccaccio's Ninfale Fiesolano in English Translation', in Renaissance Cultural Crossroads, pp. 79-99.
} 
significance of ethos to the liminal discourse of early modern translations, this chapter sheds some light on the rhetorical practices and principles that underlie even the most worn out commonplaces. In so doing, it points out the centrality of translators' liminal strategies to an understanding of their cultural identity in the first centuries of the English age of print. 


\section{CHAPTER 4 \\ Multi-Version Texts and Translators' Anxieties: \\ Imagined Readers in John Florio’s Bilingual Dialogues \\ Belén Bistué}

"Reader, good or bad, name thyself, for I know not which to tearme thee".

John Florio (1591)

John Florio's Firste Fruites, which yeelde familiar speech, merie Proverbes, wittie Sentences, and golden sayings (1578) are faithful to the title's promise of abundance. The first part of the book offers a series of short dialogues that involve phrases applicable to different situations. In addition to ideas for amorous conversation with beautiful women, there are phrases for those who may need to speak to gentlemen and gentlewomen, ask a servant for information, talk about England, or respond during an encounter in the dark. The dialogues are followed by short discourses on various topics, a collection of proverbs, some passages from known authors (mostly from the then fashionable writings of Antonio de Guevara), a thematic lexicon, some prayers, an Italian grammar, and a set of rules for English pronunciation. In this way, the work brings together most types of the aids to language learning that were used at the time. It does so for the benefit of both English and Italian learners, since, with the exception of the rules for grammar and pronunciation, all the materials are offered in bilingual format: Italian and English versions are set forth in parallel columns. 
Indeed, John Florio (1553-1625) seems to have envisioned an array of readers. That is, while the double-version arrangement can be said to offer two clear-cut positions (one for English learners of Italian, and one for Italian learners of English), Florio's introductory letters address more — and more specific — possible readers, including English gentlemen, Italian gentlemen, Italian merchants, and "the friendly, courteous, and indifferent reader". The question of the identity of his readers still resonates in the opening lines of the letter "To the Reader" in Florio's Second Frutes (1591), quoted at the opening of this chapter, where Florio is still attempting to "term" different types of readers his book may have. ${ }^{2}$ As we will see, some of Florio's concerns arise from actual responses to his first work. Others can be understood with reference to the book trade, and to his own uncertain social position as a language teacher. However, I also argue that Florio's general interest in identifying readers can be better understood in the larger context of the production of multilingual translations. This chapter seeks to demonstrate that, in the early modern period, such production began to pose increasing challenges for translators and printers within and beyond the European book market.

Following in the steps of a long manuscript tradition, many early modern printers prepared multilingual editions — not only of aids to language learning (dialogue and proverb collections, dictionaries, and grammars), but also of works as diverse as the Bible, scientific treatises, the Roman and Greek classics, Aesopic tales, pamphlets, even complete romances. This practice also seems to have been meaningful for translators, copyists, and editors, all of

\footnotetext{
${ }^{1}$ John Florio, Florio. His firste Fruites: which yeelde familiar speech, merie Proverbes, wittie Sentences, and golden sayings (London: Thomas Dawson for Thomas Woodcock, 1578), fols. **i_**iii.

2 John Florio, "To the Reader", in Florios Second Frutes, To be gathered of twelve Trees, of divers but delightsome tastes to the tongues of Italians and Englishmen (London: Thomas Orwin for Thomas Woodcock, 1591), fol. [A5].
} 
whom took great care to correlate different versions, using a variety of strategies and formats. Yet, as the sixteenth century advances, in some prefatory materials of these works we begin to see expressed concerns similar to Florio's. Above all, there emerges a certain anxiety about who the readers of these works may be, and about their gender, age, status, position, or office in particular. The analysis of Florio's work offered by this chapter helps to define the 'problem' represented by multilingual translations in the context of early modern processes of linguistic unification.

\section{A Short Survey of Multilingual Printing, 1470s to the Early Seventeenth Century}

When first published in 1578, Florio. His firste Fruits might have been perceived as less conventional than other texts prepared by contemporary language teachers such as the celebrated Claudius Hollyband. As Michael Wyatt explains, Florio pays more attention to literature and assigns a central place to practical speaking, rather than to grammatical mastery and classroom dynamics. In addition, the Firste Fruites combine a remarkable number of learning-aid genres. Still, the work is clearly inscribed in an established line of work with respect to the type of genres used and the multi-version format. By the time the Firste Fruites appeared, Hollyband had already published The Frenche Schoolemaister (1565) and The Frenche Littelton (1566), which included bilingual dialogues, with the English and French versions presented on facing pages. And Hollyband would later add to this list an Italian Schoolemaister (1583, in English and Italian), and a Campo di fior, or else The flourie field of foure languages ... for the furtherance of the learners of the Latine, French, English, but chieflie of the Italian tongue (also of 1583, in the four said languages). ${ }^{3}$ Even earlier, we can

\footnotetext{
${ }^{3}$ Michael Wyatt, The Italian Encounter with Tudor England: A Cultural Politics of Translation (Cambridge: Cambridge University Press, 2005), pp. 163-168.
} 
find a series of multilingual dialogues coupled with dictionaries that grew out of the 1511 Flemish-and-French vocabulary attributed to Noël de Berlaimont. By 1558, there already existed a four-language edition published in Antwerp that included dialogues: a Dictionarium colloquia sive formulae quatuor linguarum. In its many later editions the work continued to incorporate more languages - as shown, for instance, in a Colloquia et dictionariolum sex linguarum (1576), a Colloquia et dictionariolum septem linguarum (1585), and a Colloquia et dictionariolum octo linguarum (also printed in 1585). ${ }^{4}$ To gain an idea of the languages that were being added, we can consider the example of a 1589 seven-language edition, which encompasses Flemish, English, German, Latin, French, Spanish, and Italian set out on parallel columns across facing pages. (Figure 9)

\section{[PLACE FIG.9 HERE]}

[CAPTION FOR FIG. 9: ] Figure 9: Colloquia et dictionariolum septem linguarum (Liège, 1589), V4v-V5. By permission of the Huntington Library, San Marino. The section shown offers phrases for giving instructions to deliver a letter, as well as an example for the letter's opening lines, in Flemish, English, and German columns on the verso page, and Latin, French, Spanish, and Italian on the facing recto.

Even when multilingual dictionaries and vocabularies were published by themselves (that is, unaccompanied by dialogue collections), they constituted a genre in which new variants proliferated. Sometimes organised by thematic clusters, and sometimes alphabetically, they were arranged as lists of equivalent words in different language combinations, including both

\footnotetext{
${ }^{4}$ For a list of the numerous editions that grew out of Berlaimont's work see Andrew Pettegree and Malcolm Walsby (eds.), Netherlandish Books: Books Published in the Low Countries and Dutch Books Printed Abroad before 1601 (Leiden: Brill, 2010), pp. 157-162.
} 
ancient and vernacular tongues. As in the case of dialogues, successive editions of the dictionaries and vocabularies tended to keep building upon previous editions, and adding more languages. Konrad Gesner's Dictionarium undecim linguarum (1598)—which was based on the famous work of Ambrogio Calepino-included as many as eleven languages, as does John Minsheu's Hegemon eis tas glossas /Ductor in Linguas (1617). This practice had also accompanied the Europeans in their colonisation of the Spanish American territories: as early as 1539 the Mexican press began producing multilingual doctrines, confession manuals, vocabularies, and grammars. In these cases, the versions included Spanish and Amerindian languages such as Nahuatl, Otomi, Aymara, and Quechua, among others. Still extant is an edition of Alonso de Molina's Vocabulario en lengua castellana y mexicana which was published in 1555 , predating by twenty-three years the publication of the Firste Fruites.

\section{(Figure 10)}

\section{[PLACE FIG.10 HERE]}

[CAPTION FOR FIG. 10: ] Figure 10: Alonso de Molina, Vocabulario en lengua castellana y mexicana (México, 1555). Courtesy of the Biblioteca de la Universidad Complutense, Madrid.

As my previous work has shown, there were many other genres for which multilingual translation was frequently used..$^{5}$ Among them are proverb collections-another type of learning aid that Florio's book includes. As well as Desiderius Erasmus's famous Adagia, where we find Greek and Latin versions of proverbs, there are examples of other works with

\footnotetext{
${ }^{5}$ See Belén Bistué, Collaborative Translation and Multi-Version Texts in Early Modern Europe (Farnham: Ashgate, 2013), chapter 3.
} 
a stronger pedagogical orientation, such as the proverb compilation by Pedro Simón Abril, rendered in Greek, Latin, and Spanish interlinear versions and included in his Greek grammar of $1587 .{ }^{6}$ Aesopic fables constitute another category in which printed multilingual translations appeared very early, and very often. In 1476 we find a Latin-and-German edition prepared by the humanist physician and translator Heinrich Steinhöwel, and printed in Ulm by Johann Zainner. In 1479, a Latin-and-Italian Aesopus moralisatus (in medieval Latin verse with accompanying Italian sonnets by Accio Zucco) was printed at Verona. A year earlier, Bonus Accursius had printed a Greco-Latin Aesop in Milan, and there are at least six other extant Renaissance Aesopic collections printed in Greek and Latin, including Aldus Manutius's 1505 Aesop, in which the latter's own Latin versions were used. Moreover, within the literary realm, other examples of multilingual translations include works as varied as the famous Stephanus edition of Plato's Dialogues (1578), John Wolfe's 1588 trilingual edition of Il Cortegiano (in Italian, French, and English), and popular sentimental romances such as the numerous two-, three-, and four-language editions of The History of Aurelio and Isabell, Daughter of the King of the Scotts produced during the sixteenth and seventeenth centuries. $^{7}$

\footnotetext{
${ }^{6}$ Manuel Breva-Claramonte offers a facsimile reproduction in La didáctica de las lenguas en el Renacimiento: Juan Luis Vives y Pedro Simón Abril (Bilbao: Universidad de Deusto, 1994).

${ }^{7}$ There are at least two extant four-language editions of The History of Aurelio and Isabell (in French, Italian, Spanish, and English), printed in Antwerp in 1556 and Brussels in 1608 respectively. The Bibliographie Hispanique (New York: Hispanic Society of America, 1912) lists several earlier bilingual editions in Italian and French, printed in Paris, in 1546, 1547, 1553, 1574, and 1581, and at Lyon, in 1552 and 1555, as well as a Spanish-and-French edition, printed in Antwerp in 1560. Joyce Boro has identified the source for these translations as Juan de Flores's Grisel y Mirabella (1495); Boro mentions twenty-three multilingual editions of Flores's work, and eight bilingual editions of the romance of Arnalte y Lucenda, as well as eighteen bilingual editions of Diego de San Pedro's Cárcel de amor. See Joyce Boro, ‘Multilingualism, Romance, and Language
} 
Another rich field for multi-version printing was that of the sciences. Abraham Ortelius's Synonymia geographica (1578), for instance, offers names of different peoples, regions, and topographic features in a variety of languages, namely Latin, Greek, Arabic, Armenian, Chaldaic, and Hebrew. An additional list provides vernacular equivalents for place names or, to quote Ortelius, "barbaric and recent names of places". ${ }^{8}$ Knowledge of alternative names in multiple languages was also a key feature in plant treatises, or herbals. As in the case of dialogues and dictionaries, herbals built upon information found in earlier works and continued to incorporate new languages. Thus while medieval and early Renaissance works tended to offer the names in two languages, or several alternative names in the same language, Leonhart Fuchs's famous herbal, De historia stirpium commentarii insignes (1542), already offers Greek, Latin, and German names.

William Turner's Libellus de re herbaria novus (1538) includes Greek, Latin, and English, and in later works Turner continued to incorporate further languages. By 1551 he had published A new Herball wherein are conteyned the names of Herbes in Greke, Latin, Englysh, Duch, Frenche, and in the [A]potecaries and Herbaries Latin. In 1562 he added a second part to this work, which extended its scope to Italian. ${ }^{9}$ A similar process of

Pedagogy; or, Why Were So Many Sentimental Romances Printed as Polyglot Texts?', in Fred Schurink (ed.), Tudor Translation (New York: Palgrave Macmillan, 2011), pp. 18-38, at p. 18.

${ }^{8}$ Abraham Ortelius, Synonymia geographica, sive Populorum, Regionum, Insularum, Urbium, Opidorum, Montium, Promontoriorum, Silvarum, Pontium, Marium, Sinuum, Lacuum, Paludum, Fluviorum, fontium, \&c. variae, pro auctorum traditionibus, saeculorum intervallis, Gentiumque idiomatis \& migrationibus, appellationes \& nomina. (Antwerp: Christophe Plantin, 1578).

${ }^{9}$ The seconde part of William Turners herball wherein are conteyned the names of herbes in Greke, Latin, Duche, Frenche, and in the apothecaries Latin, and somtyme in Italiane (Köln: haer. Arnold I Birckmann, 
accumulation can be traced in herbals that were based on the Cruydeboek (1554) by Flemish physician and botanist Rembert Dodoens - a "herb book" in which plant names are specified in Flemish and Latin. Translations into other languages continued to increase the number of languages in which plants where named. Dodoens's Niewe Herball, or Historie of Plantes (1578) - the English version of the French version of the Cruydeboek - gives Greek, Latin, Spanish, Italian, German, and French names. As such, we are told that the "Southrenwood is

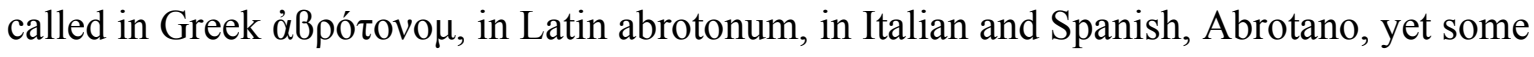
of them call it Hyerva Lombriguera, in high Douch, Stabwurtz, Gertwurtz, Garthagen, Shoswurtz, Kuttelkraut, Affrusch, in base Almaigne Averoone, in French Avronne". ${ }^{10}$ The alternative terms appear here not in facing pages or parallel columns, but in the form of equivalent words, in different languages, combined in the same sentences, where the different languages are marked with different typographical arrangements: Greek types for the Greek, Roman types for Latin, italics for Italian, Spanish, and French, and gothic for German and English. (Figure 11)

\section{[PLACE FIG. 11 HERE]}

[CAPTION FOR FIG. 11:] Figure 11: Rembert Dodoens's Niewe Herball, or Historie of Plantes ([Antwerp], 1578). By permission of the Huntington Library, San Marino. The multilingual section on "Names" appears towards the middle of the page.

1562). A third part was published in 1568 . The work has been edited by George T. L. Chapman, Frank McCombie, and Anne Wesencraft, in William Turner, A New Herball, (2 vols., Cambridge: Cambridge University Press, 1995).

${ }^{10}$ Rembert Dodoens, Niewe Herball, or Historie of Plantes (Antwerp: Hendrik van der Loe ven. Gerardus Dewes (London), 1578), p. 2. 
The multi-version arrangement of the names of plants in early modern herbals has tended to be disregarded by twentieth-century scholars. Agnes Arber, for instance, considers that Fuchs's herbal is "without importance in the history of plant classification", because its alphabetical arrangement precludes an attempt at grouping plants according to their natural characteristics. ${ }^{11}$ And the editors of Turner's New Herball lament the "fragmenting effect" of this work, which stems from its lack of a taxonomic structure. ${ }^{12}$ Nevertheless, I would like to briefly argue for the importance of herbals in the history of plant naming and classification. I find that when we compare the multilingual system characteristic of early modern herbals with the new nomenclature of the eighteenth century, the multi-version organisation also proves to be a paradigm for classificatory knowledge. In the new system established by Carl Linnaeus plants are named in Latin only, according to their genus and species. Therefore, the names invite us to establish "family connections" among the plants. When we learn, for instance, that the cucumber is called Cucumis sativus, we can relate it to the cantaloupe, which is called Cucumis melo. By contrast, in a multilingual system we would perhaps learn that the cucumber is called cucumis in Latin, and pepino in Spanish, and cetriolo in Italian, names that would not prompt reflection on the fruit's generic connections with the cantaloupe. However, these linguistic variations encourage other connections. For instance, they may invite readers to consider the peoples and places where the plants are known by the different names. Thus, while Linnaeus's system began to emphasise connections among the objects studied, the multilingual system had emphasised connections among different places in which the knowledge about specific plants was being generated and passed on.

\footnotetext{
${ }^{11}$ Agnes R. Arber, Herbals, their Origins and Evolution: A Chapter in the History of Botany, 1470-1670 (Cambridge: Cambridge University Press, 1938), p. 70.

12 Turner, A New Herball, II, pp. 8-9.
} 


\section{Polyglot Bibles and Prefatory Uncertainty}

One last genre I wish to consider in this short survey is that of multi-version editions of the Christian scriptures: polyglot Bibles, Psalters, Gospels, and New Testaments. As Walter Berschin once remarked, not much is known about how polyglot Biblical texts were read, yet their production reached the Renaissance in an unbroken tradition that spans the entire Middle Ages. ${ }^{13}$ During the sixteenth and seventeenth centuries, at least forty different Biblical polyglots that combine three languages or more were printed in Europe. ${ }^{14}$ These include the first printed polyglot Psalter - the Genoa Psalter of 1516, prepared by Agostino Giustiniani with the help of different experts. It combines across facing pages a Hebrew version, a Latin version of the Hebrew, the Latin Vulgate, the Greek Septuagint, an Arabic version, an Aramaic version in Hebrew Characters, and a Latin version of the Aramaic. There are also the five editions of Erasmus's Greek-and-Latin New Testament $(1516,1519,1522$, 1527, and 1535), as well as the Great Polyglot Bibles, which include the Complutensian Polyglot (1514-17), the Antwerp Polyglot (1569-73), and the London Polyglot of Brian Walton (printed through a subscription system between 1655 and 1657). In the Complutensian Polyglot, the first volume of the Old Testament offers six versions: the Hebrew Scriptures, the Latin Vulgate, the Greek Septuagint with interlinear Latin version, and the Aramaic Targum in Hebrew characters, together with a parallel Latin version of the Aramaic. (Figure 12) The Antwerp Polyglot added a Syriac version to this number. In the

\footnotetext{
${ }^{13}$ Walter Berschin, Greek Letters and the Latin Middle Ages: From Jerome to Nicholas of Cusa, trans. Jerold C. Frakes, revised, and expanded edition (Washington DC: The Catholic University of America Press, 1992), pp. $38-39$.

${ }^{14}$ See Thomas H. Darlow and Horace F. Moule's Historical Catalogue of the Printed Editions of Holy Scripture in the Library of the British and Foreign Bible Society (2 vols., New York: Kraus Reprint, 1963).
} 
seventeenth century the London Polyglot would also add an interlinear Latin version to the Hebrew, as well as Arabic and Hebrew-Samaritan versions with their corresponding Latin translations, creating a total of thirteen versions. (Figure 13)

\section{[PLACE FIG. 12 HERE]}

[CAPTION FOR FIG. 12: ] Figure 12: Old Testament. Complutensian

Polyglot Bible. Berkeley fBS1 1514. Courtesy of the Bancroft Library, University of California, Berkeley.

\section{[PLACE FIG. 13 HERE]}

[CAPTION FOR FIG. 13: ] Figure 13: Old Testament. London Polyglot Bible.

Berkeley f BS1 1655. Courtesy of the Bancroft Library, University of

California, Berkeley.

Unfortunately, the prefatory materials that accompany these works provide no certain indications regarding ways in which the books were read. Rather, as in the case of Florio's letters, the paratexts reveal some insecurity regarding this matter. With reference to the Biblical polyglots, a helpful immediate context for appreciating this uncertainty can be found in religious controversies - and specifically the idea that only one version of the Bible could be legitimate was acquiring more and more force as the sixteenth century progressed. Indeed, some of the translators and scholars who had collaborated in the production of the Catholic Polyglot Bibles (the Complutensian and the Antwerp Polyglots) were denounced to the Roman Inquisition for making available Latin versions that competed with the Vulgate Bible. The Greek expert Juan de Vergara, for instance, was arrested in 1533 and questioned by the Inquisition; in his response to the charges, he defended the criteria he had used when 
producing Latin interlinear translations for the Complutensian Polyglot Bible. ${ }^{15}$ Benito Arias Montano, the Augustinian theologian who supervised the Antwerp Polyglot, was denounced to the Inquisition in 1572 because this Bible did not clearly present the Latin Vulgate as the authoritative version. ${ }^{16}$ The multiplicity of versions presented by these Bibles manifestly challenged the drive towards religious unification, a drive that was formalised in the 1546 Tridentine official decree that the Vulgate Bible was the only authoritative Latin text to be used in sermons and disputations.

In fact, some unease caused by multiplicity can be detected already in the prefatory texts that are part of the earliest of the Great Polyglot Bibles, the Complutensian Polyglot. Here the prologue to the Old Testament-addressed "to the studious reader"-juxtaposes two different explanations for the correlation of versions. In the first explanation, the reader is told that the three ancient versions of the Pentateuch (the first five books of the Old Testament) are accompanied by three corresponding Latin translations:

The Pentateuch has three languages: namely the Hebrew, the Chaldaic (Aramaic), and Greek, which we have printed together with three different Latin corresponding interpretations, so that in this way the Hebrew corresponds with the Latin translation of the blessed Jerome, the Chaldaic with another Latin version, closely rendered word

\footnotetext{
${ }^{15}$ Process against Juan de Vergara at the Toledo Inquisition, cited in Marcel Bataillon, Erasmo y España (2 vols., Mexico: Fondo de Cultura Económica, 1950), I, pp. 40-41.

${ }^{16}$ Robert J. Wilkinson, The Kabbalistic Scholars of the Antwerp Polyglot Bible (Leiden: Brill, 2007), pp. 94-96.
} 
by word by a man who is most expert in this language, and the Greek of the seventy interpreters with a Latin translation in interlinear arrangement. ${ }^{17}$

The idea that the reader is faced with three main versions, each accompanied by its Latin rendering, is emphasised in the title of the volume: "Vetus testamentum multiplici lingua nunc primo impressum. Et imprimis Pentateuchus Hebraico Greco atque Chaldaico idiomate. Adiuncta unicuique sua latina interpretatione" ("The Old Testament in multiple languages now printed for the first time. And first is printed the Pentateuch in Hebrew, Greek, and Chaldaic languages, each of them with its accompanying Latin translation"). Nevertheless, a few lines later in the same prologue there appears a series of metaphors that offer a second, competing explanation of the relation among versions:

Once the codex is opened, it will offer you two page faces, each of which has three principal columns. Of these, there is one placed on the exterior margin that contains the Hebrew scripture, and there is one which keeps close to the interior margin, and this is the Greek edition of the Seventy interpreters, whose corresponding Latin wordfor-word translation is placed on top of each line. And in the middle of these versions, we placed the Latin translation of the blessed Jerome, as if it were set in between the Synagogue and the Oriental Church. Just as Jesus was in the middle of the two thieves, here we have placed the Roman or Latin Church. This version alone, built upon solid rock (offering a correct understanding of the Scripture for whenever we

\footnotetext{
${ }^{17}$ Vetus Testamentum multiplici lingua nunc primo impressum [Complutensian Polyglot] (6 vols., Alcalá de Henares: Arnao Guillén de Brocar, 1514-1517), I, fol. + iii ${ }^{v}$. Unless otherwise acknowledged, all translations in this chapter are by Belén Bistué.
} 
deviate), remains always steady in the truth. In addition, beneath these three columns, two other minor columns are set at the bottom of the page, of which the wider one contains the Chaldaic scripture and the narrower its Latin interpretation. ${ }^{18}$

The comparison of Jesus's central place at the crucifixion with the constancy of the Roman Church, together with the metaphor of the solid rock foundation, give the Vulgate a hierarchical place that the preceding explanation does not bestow. This place is further emphasised by the description of the other two columns, the Aramaic Targum and its Latin version, as "minor" ones (minore columnellae).

Thus, while these two explanations are not fully contradictory, they propose two constrasting readings. In the first interpretation there are three equivalent scriptural languages (Hebrew, Greek, and Aramaic) accompanied by their three Latin versions, and in the second interpretation such threefold equivalence is completely lost. The Vulgate (one of the three accompanying Latin versions) becomes the central column, with the Hebrew and Greek versions assuming the place of the crucified thieves; the Aramaic and its Latin translation are now described as minor columns, and the interlinear version of the Greek is tacitly omitted from the picture. These alternative explanations actually generate space for two different reading positions: certainly that of "the studious reader", who may wish to compare or correlate the three scriptural languages, but also the position of what might be termed the censorious reader, who (at least visually) will be able to assign the central, authoritative place to the Vulgate. In this way, the discontinuities between the two different explanations, as well as the abundance of comparisons and images, already reveal a preoccupation with who will read this multi-version work, and how it will be read.

\footnotetext{
${ }^{18}$ Vetus Testamentum multiplici lingua, I, fol. + iii ${ }^{\mathrm{v}}$.
} 
It must be noted that similar apprehensions were expressed in the Protestant movement. Brian Walton, the Anglican scholar in charge of the London Polyglot, was obliged to defend this multi-version work against attacks from Nonconformist theologian John Owen. In this case, Owen's attack was based on the claim that the only authoritative version for the Old Testament was the Hebrew or, to quote Owen, the "Divine Originall". Accordingly, Owen denounced Polyglot Bibles for printing "the Originall it selfe, and defam[ing] it, gathering up translations of all sorts, and setting them up in competition with it". ${ }^{19}$ Thus he establishes a clear opposition to the use of multilingual translations of the Scriptures.

Walton, in turn, defends the London Polyglot against this accusation. However, in Walton's defense we can also detect some uncertainty regarding possible ways in which the combination of different versions will be handled by the reader. He is not too worried about the charge of defamation of the original; he simply disregards it as false. Instead, he is more interested in proposing different possible ways in which the translations might be used. "First", he says, "because all cannot understand the Originall Tongues, therefore Translations serve as so many Pipes or Channels to convey those living waters of salvation from the Fountains to every particular Nation and People, that so all may read and hear the wonderfull works of God in their own Tongue". Yet just a few lines after invoking this metaphor, he offers another possibility; rather than imagery in which the versions spread out to reach different readers, this time he uses an image of concentration. He states that translations may also "serve as so many glasses to declare the true sen[s]e and meaning of the Scripture, as it was understood in those times, when they were made, especially as they are exhibited in this

\footnotetext{
${ }^{19}$ John Owen, 'Epistle Dedicatory', in Of the Divine Originall, Authority, self-evidencing Light, and Power of the Scriptures (Oxford: Henry Hall, 1659), fol. *6.
} 
Work, where they may at one view, be all compared together". He then adds that part of the value of the versions lies in the fact that they "represent the sen[s]e of so many great and famous ancient Churches". ${ }^{20}$

In addition to revealing Walton's awareness of the rich cultural and historical layers of a multi-version text, like the preface to the Complutensian Polyglot, these metaphors also point to a marked interest in exploring the reading possibilities for multi-version texts. As in the case of the Complutensian preface, too, the alternative possibilities explored are not fully compatible with one another, and do not offer a univocal explanation of how the work is expected to be read. In Walton's first metaphor (the pipes that carry water away from the fountain), each of the versions will be used by a different reader who will read in his "own tongue". In the second (in which each version becomes a particular glass that reveals how the version was "understood" at the time when it was made), there seems to be a single imagined reader who will compare all the versions at "one view". To this option, I believe we can add the possibility that the many versions be compared not by a single reader but by a group of readers who will study and discuss the Bible together. Another feature of Walton's explanations is his attempt to associate the different versions with different reading identities. In the first metaphor, each reader is identified with a different tongue, and with a different Nation or People that bears this linguistic identity. Towards the end of the passage, however, the versions are also identified with different ancient Churches, that is, with different religious identities. Thus, I believe Walton's explanations reveal his uncertainty regarding the reader; rather than setting forth a concrete answer to the charge that the many versions will

\footnotetext{
${ }^{20}$ Brian Walton, The considerator considered: or, a brief view of certain Considerations upon the Biblia Polyglotta, the Prolegomena and Appendix thereof (London: Thomas Roycroft, 1659), pp. 86-88.
} 
corrupt the original, his metaphors propose alternative ways in which the book might be read, and different categories with which readers might identify themselves.

As mentioned earlier, the struggles and explorations we find in these prefatory texts can be understood in the context of ideological struggles about religious unification and divine authority. However, an interest in determining possible readers and their identities can also be found in the prefatory materials of other types of multilingual translations. As the following section shows, similar preoccupations emerge in other contexts. In particular, we find concerns about reading identities expressed by translators, editors, and publishers of multi-version language aids, including the very telling prefatory letters of John Florio.

\section{Florio's Readers-English, Italian, and "of any other sort"}

An interest in determining possible readers appears already in the titles of many multilingual dialogues and vocabularies. In numerous cases, of course, only one type of reader is envisioned. There are, for instance, Latin and English dictionaries described exclusively as school dictionaries. Further, there are long titles that emphasise only one of the languages and only one type of reader, such as John Veron's Dictionary in Latine and English ... for the utilitie and profite of all young students in the Latine tongue (London, 1575), or the French Garden: for English ladyes and gentlewomen to walke in (London, 1606). Yet other works expand their imagined audiences. For instance, the prologue to an Introductio quaedam utilissima sive Vocabularius quattuor linguarum Latinae, Italicae, Gallicae et Alamanicae (Rome, 1510) presents this work as "utilissimus vocabularius pro his, qui desiderant intelligere et scire legere sine visitatione scholarum, sicuti sunt mechanici et muliers" (or, in the English version of a later six-language edition of this work, "a right profitable vocabulary to rede for them that shold desire it without going to schole, as 
artificers and women"). ${ }^{21}$ The title page of the popular English, Latine, French, Dutch scholemaster (London, 1637) promises "to teach young gentlemen and merchants to travell or trade", and that of a later Nomenclatura clericalis, or, The young clerk's vocabulary in English and Latine (London, 1685), deemes the work "very necessary and useful, not only for young clerks" — as one would expect from the title_- "but also for young scholars, apothecaries, chirurgions, coroners, clerks of the peace, and several other persons". Even more enthusiastic, the Latin-and-English Bibliotheca scholastica. A double dictionarie (Oxford, 1589) advertises itself as "verie profitable and necessarie for scholars, courtiers, lawyers and their cl[e]rkes, apprentices of London, travellers, factors for marchants, and briefly for all discontinuers within her Majesties realmes of England and Ireland". And if we believe the title page of Hieronymus Megiser's many-languaged Thesaurus, polyglottus, vel dictionarium multilingue (Frankfurt, 1603), this work was of use "not only to philologists but also to students of letters, ... to teachers, and, even to historians, geographers, physicians, chemists, as well as to clerks and legates, and to those who travel: merchants and spice traders, as much as soldiers and their officers". ${ }^{22}$

The urge to identify reader types who can profit from these works is summarised by the title of a four-language vocabulary that advertises its usefulness for all merchants, and for all others regardless of their position; also by a Spanish-and-French collection of dialogues

\footnotetext{
${ }^{21}$ Sex Linguarum Latinae, Gallica, Hispanicae, Italicae, Anglicae, et Teutonicae dilucidissimus dictionarius (Venice: Francesco Bindoni and Mapheo Pasini, 1549), fol. A ii.

${ }^{22}$ [N]on Philologis tantum humaniorisque, literaturae studiosis . . Professoribus, imprimis vero Historicis, Geographis, Medicis, Chymicis, Principum quoque Scribis \& Legatis, aliisque peregrinantibus: Mercatoribus item \& Aromatopolis: ipsisque adeo Militibus, Militumque Praefectis, ut pernecessarium, ita maximo usui futurum. Extended title of Thesaurus polyglottus; vel, Dictionarium Multilingue (Frankfurt: Hieronymo Megisero, 1613).
} 
described as very convenient and most profitable . . for all qualities of persons. ${ }^{23}$ Such titles convey a sense that the book's plurality of languages opened up the conceptual possibility of other reading positions_- positions available to readers of different languages and to readers belonging to different social groups. We also saw some form of displacement in Walton's defense of polyglot Bibles, where he connects the different languages firstly with different nations and peoples and secondly with different religious traditions (with the different ancient Churches). In the case of multilingual dictionaries and dialogues, the multiplicity of languages is projected onto a multiplicity of social identities.

Of course, the mention of potential reader types was a common feature in the title pages of printed works (a book could be profitable to all Christians, another to physicians, and yet another to gentlewomen). What stands out in the titles I have cited is the multiplicity of imagined potential readers for whom the same work can be of use - and the urge to assign an identity to this array of readers. One context in which to understand this multiplicity is that of the book trade, where multilingual translations were expected to be a profitable object. The imagined profit for readers may very well have been a projection of the printer's expectations of monetary gain. Of course this does not mean that the number of advertised readers reflects the actual commercial success of multilingual translations. Both translators and printers must have harboured their doubts. After all, one could think that if the same book could be read by different readers, then printers might have been missing the chance to sell a different copy to each of them. Or if a reader was interested in learning three languages,

\footnotetext{
${ }^{23}$ Diccionario coloquios, o, dialogos en quatro lenguas, flamenco, frances, español y italiano . . Obra muy provechosa para todos mercaderes y otros de qualquier estado que sean (Amsterdam: C. Nicolas, 1580); Coloquios familiares muy convenientes y mas provechosos de quantos salieron fasta agora, para qualquiera qualidad de personas desseosas de saber hablar y escribir español y francés (Antwerp: Iean Wasberge, 1568).
} 
then why have this reader buy one book that combines all three languages, instead of three separate books? Here it is helpful to recollect that production of a multi-version book required almost the same amount of work, paper, and ink as three separate single-version books. Therefore, it is probable that the abundance of advertised reader types actually signals a distinct anxiety about the measurable profits these works could bring in the context of the book trade.

However, beyond commercial uncertainty, there seem to be other concerns at play. Closer study of these works reveals that the eagerness to determine potential readers is often accompanied by other expressions of fear. John Florio's prefatory letters to his multilingual dialogues are a particularly telling example. The title page of the Firste Fruites does not mention any anticipated readers. Nevertheless, his letters do. In addition to dedicatory epistles to Lord Robert Dudley (one in Italian and one in English), there are three different letters to the reader. The first one, in Italian, is addressed "A tutti i Gentilhuomini Inglesi che si dilettano de la lingua Italiana" ("To all English gentlemen who take pleasure in the Italian language"). This is succeeded by a brief second letter, presented in English and addressed "Unto the friendly, curteous, and indifferent Reader". A third letter then follows, again in Italian, "A tutti i Gentilhuomini, e Mercanti Italiani, che si dilettano de la lingua Italiana" ("To all Italian Gentlemen, and Merchants, who take pleasure in the English language"). Together these three letters create a slight lack of balance between letters and languages (one letter in English and two in Italian; the letters to English and Italian readers are both in the same language). This unbalance stands out in a work that offers the rest of its materials in 
parallel double versions. It stands out, too, in the context of other multilingual aids, many of which offered introductory materials in a balanced multi-version format. ${ }^{24}$

The disproportion is further emphasised by the addition of an extra addressee in the third letter, which is dedicated not only to "gentlemen", as the letter to English readers was, but also to "merchants" ("To all Italian Gentlemen, and Merchants"). What is more, this multiplication of readers continues inside the third letter, where Florio guarantees that the reader himself will be able to address different types of audiences. In a phrase that evokes the titles of multilingual learning aids, Florio tells the reader that, with the help of these dialogues, he will be able to speak "con huomo, con donna, con Mercante, con Signore, ó con ogni altra sorte di Génte" ("with man, woman, Merchant, Lord, or with any other sort of People"). ${ }^{25}$ Here Florio uses the categories normally assigned to the many imagined readers of multilingual dialogues so as to describe the many imagined interlocutors these readers will reach. In the contents of the book, Florio will extend the displacement, and continue to use these categories for the imagined interlocutors in the dialogues. We can see this at work in a short dialogue intended to teach "To speak with a woman" / "A parlar con donna" (chapter 10), followed by one that teaches "To speake to a servant" / "A parlar con servitore" (chapter 11). (Figure 14). The previous chapters have already offered "familiar" ways to speak with a “damsel” (chapter 2), with "man or woman" (chapters 3 and 5), a "gentleman" (chapter 7), a "gentlewoman" (chapter 8), and a "merchant" (chapter 9).

\section{[PLACE FIG. 14 HERE]}

\footnotetext{
${ }^{24}$ Hollyband's French scholemaister, for instance, offers the introductory letter to the reader in English and French versions on facing pages, and the 1549 Sex Linguarum . . dictionarius, cited at the beginning of this section (see n21) gives its introduction in six equivalent versions.

${ }^{25}$ Florio, Firste Fruites, fol. ** iii.
} 
[CAPTION FOR FIG. 14: ] Figure 14: Florio. His firste Fruites (London, 1578), fols. $8^{\mathrm{v}}-9^{\mathrm{r}}$. Reproduced by permission of the Huntington Library, San Marino.

This is not to say that the whole of the book is organised according to the type of expected interlocutor. In fact, such a structure is lost already in the last few dialogues, which are either described as general "familiar speeches" or according to the discursive situation-there is one for "Amorous talke" (chapter 14), one "To speak of England" (chapter 15), and one "To talke in the darke" (chapter 17). In addition, as mentioned earlier, the remainder of the book is composed of a great diversity of materials: sentences, proverbs, sayings, demands, discourses and reasons on a variety of topics (including peace and war, the abuses of the world, beauty, nobility, poverty, different virtues and positive qualities, manners, arts, vices); many gallant sayings and discourses by Antonio de Guevara (again on a variety of topics); a bilingual lexicon; an Italian grammar written in English, and a set of English pronunciation rules given in Italian. From this it might be proposed that the book as a whole lacks a clear organisational principle. Still, I believe it is significant that the strategy for organisation we find in the initial chapters of the Firste Fruites is a classification of dialogues according to the social position of the addressees. This strategy extends the impression of Florio's initial interest in readers' identities, an interest that becomes displaced from the types of readers addressed by his letters, to the types of interlocutors Italian readers will be able to address, to the types of interlocutors addressed in the dialogues inside the book.

Florio's Second Frutes, published in 1591, can be said to offer some further explanation for this displaced interest. In this later work, the dialogues are not classified 
according to the type of interlocutor to be addressed. ${ }^{26}$ Additionally, only one introductory letter "To the reader" is included — it is in English, and addressed to a single, general reader (rather than to different types). Nonetheless, Florio's concern with the reader emerges right at the beginning of the letter:

Reader, good or bad, name thyself, for I know not which to tearm thee, unless I heard thee read, and reading judge, and judging exercise: or curtesie, the cognisance of a Gentleman, or malice, the badge of a Momus, or exact examination, the puritane scale of a criticall censor. To the first (as to my friends) I wish as gracious acceptance where they desire it most, as they extend where I deserve it least; to the second I can wish no worse than they worke themselves, though I should wish them blyndnes, deafnes, and dumbnes .... As for critiks I accompt of them as crickets; no goodly bird if a man marke them, no sweete note if a man heare them, no good luck if a man have them.

Understandably, Florio is particularly bitter towards this last type, and he makes a special effort in his attempt to set down names for it:

[W] hat vermine to call them I know not, or wormes, or flyes, or what worse? They are like cupping glasses, that draw nothing but corrupt blood; like swine, that leave the cleare springs to wallow in a puddle ... . They will do nought, yet all is naught but what they doo; they snuff our lampes perhaps, but sure they add no oyle; they will

\footnotetext{
${ }^{26}$ In the Second Frutes, the initial dialogues are titled according to the different times of the day and the place or situation of the conversation, and the later ones according to the topics discussed in them.
} 
heal us of the toothache, but are themselves sick of the fever-lourdane. Demonstrative rethorique is their studie, and the doggs letter they can snarle alreadie. As for me, for it is I, and I am an Englishman in Italiane, I know they have a knife at command to cut my throate: Un Inglese Italianato, e un Diavolo incarnato. ${ }^{27}$

In this long metaphorical exploration of the three types reader, Florio is still imagining possible readers for his bilingual works, and he is trying to name them. The naming in this case acquires a very negative tone, to the extent that the series of metaphors describing the critic culminate in this reader's power to have Florio killed. Here, the readers are not associated with multiple social positions but with uncontrollable, even murderous readings.

Like the sequence of metaphors, such fears finally lead us to Florio's own position. It is likely that they stem from what must have been contemporary reading responses to his Firste Fruites. Whereas the latter had been dedicated to the Earl of Leicester, Robert Dudley, the Second Frutes were dedicated to Nicholas Saunders of Ewell. As the choice of a new patron indicates, Dudley was not as generous a reader as Florio had hoped. The second and third types of readers named in Florio's opening letter ("bad" readers and "critiks") suggest that his First Fruites must have been mocked and criticised. In addition, the Italian proverb that closes the imagined threat to Florio's life refers us to a general resistance to Italian influences. More specifically, it brings to mind the attacks of Roger Ascham, who, in his educational work The Scholemaster (1570), had used the same proverb in the context of a strong critique of Italian cultural influences in England. ${ }^{28}$

\footnotetext{
${ }^{27}$ Florio, 'To the Reader', in Second Frutes, fols. [A $\left.5^{\mathrm{r}}-\mathrm{A} 5^{\mathrm{v}}\right]$.

${ }^{28}$ Roger Ascham, The Scholemaster (London: John Daye, 1570), fol. $26^{\mathrm{r}}$.
} 
Besides, as a language teacher, Florio was still a man of "uncertain social standing"- to use the phrase of Frances Yates, his twentieth-century biographer. ${ }^{29}$ And his situation was definitely complicated by what could be perceived as his dubious linguistic identity. As Michael Wyatt highlights, Florio was born in England, but grew up in Switzerland, and although he had not lived in Italy, he may have considered himself Italian because of his father's origin, and because of his mother tongue. Like other Italian families who had left Italy for religious reasons to seek refuge in England, Florio's family “occupied an ambiguous space". ${ }^{30}$ As such, the connection established in Florio's 1591 letter "To the Reader" between his double identity as an "Englishman in Italiane" (an Englishman in Italian translation, we could add) and his powerless standing before critical readers becomes highly significant. It links his difficult social position with his double linguistic identity. Also, by defining himself as a double-version man, he is almost equating himself with his doubleversion text. In this way, he is echoing the connection already witnessed in the titles of multilingual dialogues and vocabularies, which project the plurality of versions onto multiple social identities.

\section{Translators' Anxieties and the Emergence of Unified Linguistic Communities}

Indeed, as Jacques Lezra has shown, other contemporary authors of language-learning aids also linked anxieties about their own socioeconomic status and political identity with the unstable linguistic identity of their texts. To cite one example, Ascham, a didactic writer, was simultaneously worried about the Italianisation of English fashions and the pedagogical fashioning of his pupils' identities. The title page of Ascham's Scholemaster tells us that its

\footnotetext{
${ }^{29}$ Frances A. Yates, John Florio: The Life of an Italian in Shakespeare's England (Cambridge: Cambridge University Press, 1934), p. 50.

${ }^{30}$ Wyatt, The Tudor Encounter, p. 166.
} 
teaching of Latin is "specially purposed for the private bringing up of Youth in [G]entlemen and Noblemens Houses", and for those who wish to refresh their knowledge of Latin "by themselves, without a Scholemaster". Yet as Lezra reveals, Ascham's discussion of his famous double translation method highlights some of the complexities involved in this pedagogical enterprise. The proposed method involves two versions: first, the teacher's translation of a Latin passage into English, and then the student's blind retranslation of the passage into Latin. Supposedly this allows the teacher to measure how close the student has come to the original Latin style and wording. However, Lezra points out that the teacher's first version is not measured in this process. Consequently, neither is the teacher's degree of participation in the fashioning of the student's self. Just as unclear, we could add, is the degree to which the language teacher can acceptably approximate the English of gentlemen and noblemen. The silence regarding the schoolmaster's control of the first translation into Latin can be then considered symptomatic of local anxieties concerning, among other things, the formation of the pupil's self, and the socioeconomic status of the translator. ${ }^{31}$ Basically, in Ascham's double versions - and in the many dictionaries and dialogues that circulated in early modern Europe, Lezra sees traces of a "deterritorialized", "fluid", and "fractious" understanding of linguistic identity. He argues that "at the moment of the emergence of the nation form, the lexical culture of translation designates a specifically nonsubjectivist form of cultural (self) resistance". Lezra also explains, nonetheless, that this fluid understanding coexisted with the rise of proto-national categories and the notion of individual autonomy, and that it was ultimately incompatible with these ideas. ${ }^{32}$

\footnotetext{
${ }^{31}$ Jacques Lezra, 'Nationum Origo', in Sandra Bermann and Michael Wood (eds.), Nation, Language, and the Ethics of Translation (Princeton: Princeton University Press, 2005), pp. 203-228, at pp. 211-212.

${ }^{32}$ Lezra, 'Nationum Origo', pp. 206, 223.
} 
This, I believe, is the larger framework in which we can place the problems that multilingual translations begin to create for their early modern translators and printers. The various discontinuities, contradictions, displacements, and abundant multiplications we find in the prefaces and titles of these publications express an attempt — and ultimately a failureto account for their linguistic multiplicity in the context of emerging notions of unified identity. In this sense, I find Benedict Anderson's definition of the nation as an imagined community particularly helpful, especially with reference to the role he assigns to the printing press in the early processes of national-identity formation. Because printing fostered the standardisation of written languages, and made it possible to reach a rapidly growing number of readers, it promoted the formation of mass reading publics. In this way, it made it easier for European readers to begin imagining themselves as interchangeable members of unified linguistic communities. When, for example, a French-speaker read a printed book in French, he or she could now imagine that many other members of the community might read a copy of this book. Likewise for English, Spanish, and other communities of readers for which unification processes were underway. Such readers could imagine themselves as individual members of a unified linguistic group, and in this way, they became "the embryo of the nationally imagined community". ${ }^{33}$ According to this explanation, the ground for the conceptualisation of modern political communities was laid, in part, by the virtual possibility that all members of a particular linguistic community could read a copy of the same book in the same vernacular language. By contrast, this imaginative identification could not quite take place when the book offered several versions, in different languages, on the same page,

\footnotetext{
${ }^{33}$ Benedict Anderson, Imagined Communities: Reflections of the Origin and Spread of Nationalism (London: Verso, 1983), pp. 43-44.
} 
because such a page would constantly remind the reader that many other readers-belonging to different linguistic communities and cultural traditions - could read the same book, too.

Their failure to elicit the mechanism of unitary identification is a key to understanding the anxieties and uncertainties manifested in the paratexts of multilingual translations. The books' multiplicity of versions and consequent textual recognition of a multiplicity of reading positions did not fit the ideological model of unified linguistic identity. This is why translators and editors felt compelled to account for this troubling multiplicity, displacing it onto accounts of multiple reader types.

\begin{abstract}
$* * *$
As described earlier, the prologue to the Complutensian Polyglot Bible includes two competing explanations of how the relation among versions should be understood. In their discontinuity we can read a struggle with the possibility that the multiple versions could conceivably compete with the Latin Vulgate, and a related struggle with the possibility that the text would be used by readers other than "the studious reader". We also saw Walton celebrating the different possible readers of the London Polyglot—according to their different languages - only to turn back on his tracks to propose that all the versions could be read "at one view". Moving to the realm of multilingual learning aids, we have seen the multiplication of social reader-types in the title pages. Hieronymus Megiser's Thesaurus, polyglottus, for instance, may not specify the numerous languages it offers (the title page mentions only that it contains a very large number "of old, new, and even forgotten ancient languages, dialects, and idioms of the globe's nations"). ${ }^{34}$ However, the volume compensates for this lack of
\end{abstract}

\footnotetext{
${ }^{34}$ Among the many languages specifically correlated on its pages are "Arabic, Armenian, Basque, Church Slavonic, Croatian, Czech, Danish, Dutch, English, Finnish, French, German, Greek, Hebrew, Hungarian,
} 
specification with a detailed list of possible reader types: "philologists, students of letters, teachers, historians, geographers, physicians, chemists, clerks, legates, merchants, spice traders, soldiers, and officers". Last but not least, in his Firtse Fruites we have seen Florio address introductory letters to both English and Italian readers, even as the balanced account of the double linguistic structure of the work is tilted right away: having qualified both readers equally as "gentlemen", Florio adds the category of "merchants" in his second letter-where he continues with a displaced multiplication of interlocutors. This displacement is furthered afterwards in the very organisation of his text.

It is no mere coincidence that Florio associated his own problematic double-version identity with the risk posed by some of his imagined readers. Nor are the discontinuities, conflicting metaphors, displacements, and multiplications of reader types presented in this chapter without consequence. All are traces of the conceptual challenge posed by multilingual translations to those who produced them, in the context of religious, political, and linguistic unification processes for which the printed monoglot text was a much better match. All the claims and explanations studied herein can be described as anxious attempts to account for multilingual texts and the alternative conceptual models that support them.

The historical value of these attempts lies in the invitation they extend—an urgent one- to include the "troubling" texts of multilingual translations in our literary and translation studies, and with them, the techniques, strategies, and models that these texts presuppose: careful techniques for correlation, very concrete forms of word-for-word translation, and multi-version ways of organising and conceptualising knowledge. Above all,

Persian, Polish, Slovene, Sorbian, Spanish, Tartaric, Turkish, and Welsh”. William Jervis Jones, German Lexicography in the European Context: A Descriptive Bibliography of Printed Dictionaries and Word Lists Containing German Language (1600-1700) (Berlin: Walter de Gruyter, 2000), pp. 498-499. 
I believe they offer a refreshing opportunity to imagine that different readings and different reading positions can coexist. 


\section{CHAPTER 5}

"No Stranger in Foreign Lands": Francisco de Hollanda and the Translation of Italian Art and Art Theory ${ }^{1}$

\section{Elena Calvillo}

Between 1538, when Francisco de Hollanda (1517-1585) travelled to Rome, and 1548, when he completed his treatise and dialogues on antique and contemporary art, Da Pintura Antiga (On Ancient Painting), Hollanda dedicated himself to representing the best aspects of Italian culture to the Portuguese court. ${ }^{2}$ Although his primary goal was not to translate a classical text, his extensive citations of Vitruvius's De Architectura and Pliny the Elder's Naturalis Historia in Books One and Two of his work suggest the degree to which he was engaged in this humanist pursuit. ${ }^{3}$ Hollanda introduces his project by referencing a passage in Vitruvius's preface to Book Six of De Architectura, in which the Socratic philosopher Aristippus, having survived a

\footnotetext{
${ }^{1}$ I thank Nicholas Baker, Piers Baker-Bates, Andrea Rizzi, and the anonymous reader for their comments, which much improved this chapter.

${ }^{2}$ Hollanda suggests that he began his treatise upon his arrival to Portugal, begging pardon for any deficiency in it tas someone who had just arrived from a foreign land, removed from the language and refinements of the court; see Francisco de Hollanda, On Antique Painting, trans. and ed. Alice Sedgwick Wohl (University Park, PA.: Pennsylvania State University Press, 2013), p. 70, and Francisco de Hollanda, Da Pintura Antiga, ed. Angel González García Lisbon (Lisbon: Imprensa Nacional-Casa da Moeda, 1984), p. 17.

${ }^{3}$ For Hollanda's extensive citation of Pliny, see González García's thorough notes for Da Pintura Antiga, which provide Pliny's Latin text; and Elena Calvillo, 'Reading Pliny in Francisco de Holanda's Roman Dialogues', in Melinda Schlitt (ed.) Gifts in Return: Essays in Honor of Charles Dempsey (Toronto: Centre for Reformation and Renaissance Studies, 2012), pp. 263-296.
} 
shipwreck, supports himself by disputing learned subjects in the Gymnasium of Rhodes.

Aristippus thrives in a foreign land, Vitruvius implies, because his education equipped him with knowledge and skills valued in whatever civilized place he found himself. ${ }^{4}$ Hollanda's opening presentation of Vitruvius's anecdote draws a parallel between the ancient philosopher's success in Rhodes and his own trip to Rome between 1538 and 1540, which is described in Book Two of Da Pintura Antiga, usually known as the Roman Dialogues, and represented by a collection of drawings now in the Royal Library of the San Lorenzo de Escorial. ${ }^{5}$ This section from Book One of his treatise, and a collection of drawings establish Hollanda as a knowledgeable translator of Italian artistic theory and culture.

In his dialogues, Hollanda represents himself first in the illustrious company of Michelangelo and Vittoria Colonna (dialogues one through three) and later (dialogue four) in conversation with Giulio Clovio, the most celebrated miniaturist in Rome. ${ }^{6}$ Hollanda appears in all of the dialogues as a well-connected and educated young artist, a pictor doctus, capable of citing Virgil and determined to learn as much as possible about contemporary and ancient art,

\footnotetext{
${ }^{4}$ Henceforth I will quote from the English translation of Hollanda's treatise, On Ancient Painting. I will also refer to the Portuguese original edited in Da Pintura Antiga (and cite full passages when relevant). For the Latin and English texts of Vitruvius I have used Vitruvius, On Architecture, ed. and trans. Frank Granger (2 vols., London and New York: William Heinemann Ltd and G.P. Putnam's Sons, 1939): see pp. 2-3 for the story of Aristippus.

${ }^{5}$ For the dates of Hollanda's journey to Rome see Sylvie Deswarte-Rosa, 'A viagem a Itália de Francisco de Holanda (1538-1540)', in Os Descobrimentos portugueses e a Europa do Renascimento (Lisbon: Presidència do Conselho de Ministros, 1983), pp. 61-65.

${ }^{6}$ Book One of Da Pintura Antiga comprises forty-four chapters that treat the theory of art, encompassing many media; Book Two consists of four dialogues set on the Quirinal. The first three feature Michelangelo and Vittoria Colonna, while the fourth introduces the miniaturist Giulio Clovio and the medalist Valerio Belli in place of Michelangelo.
} 
while enjoying the support of King João III. He emphasizes his desire to return to Portugal, so that he might translate his newly acquired knowledge, writing, "I [...] wish for my part as much as I can not to conceal or thereby allow the loss of whatever is most important that is known of this most noble art", and "because it is so little known, it will appear very important that I express what I want to say about it in the Portuguese language". 7

Hollanda cites the passage in Vitruvius in the context of professional ambition, as a valuable member of the Portuguese court, noting that "(like Marcus Vitruvius)...I store up the assets of which this is the supreme reward, to wit, to have no need to posses any other assets of greater treasure than my own self", emphasizing his wealth "in goods which even if the ship foundered and the plundered city were burning, I can carry with me lightly, swimming or walking, without the hindrance of a burden...". ${ }^{8}$ Hollanda's light baggage, of course, is knowledge. This possession is not only impervious to shipwreck and any other reversal of

\footnotetext{
${ }^{7}$ Hollanda, On Antique Painting, p. 67; Hollanda, Da Pintura Antiga, pp. 7-8, “...eu...desejo de minha parte quanto posso não seconder, nem deixar assi perder quanto he maior do que se sabe esta nobelissima arte...Mas parecerá agora muito grande cousa dizer eu o que desejo della em lingoagem portugues, assi é mal conhecida".

${ }^{8}$ Hollanda, On Antique Painting, p. 68, and Hollanda, Da Pintura Antiga, pp. 8-9: "Pois com ella (como M. Vetruvio) ajunto a fazenda de que este é o summo fructo. Convem a saber: nam ter necessidade doutra fazenda, nem tisouro maior que ter me a mi, que a propiedade da grão riqueza não consiste em mais que em nenhuma cousa desejar. E a Vós, muito Glorioso e Augusto Rei e Senhor, dou eu outras tanta graças pola ajuda que ategora me tem dado (mandandome ir ver Italia) em bens que, inda quando se a não alagasse, e a cidade saqueada steuesse ardendo, eu posso sem empedimento de carga leuemente comigo trazer a nado, ou passeando...". For the cultural climate of Renaissance Portugal, see Sylvie Deswarte-Rosa, Ideias e imagens em Portugal na época dos Escobrimentos: Francisco de Holanda e a Teoria da Arte (Lisbon: Difel, 1992); and Joquim Oliveira Caetano, 'Francisco de Hollanda (1517-1584): The Fascination of Rome and the Times in Portugal', in Hollanda, On Antique Painting, pp. $7-43$.
} 
fortune but also the means by which he flourished in Rome and meant to succeed at home. As the anecdote about Aristippus demonstrates, "knowledge alone is not a stranger in any foreign country, or friendless when retainers and familiars are lost, but is welcomed as a citizen in all cities and a good courtier at any court". ${ }^{9}$ Hollanda slightly amends Vitruvius's citation of Theophrastus's assessment that the learned man is no "stranger in foreign lands" but a citizen in every state by inserting "a good courtier at any court" ("bom cortesão em qualquer côrte"). ${ }^{10} \mathrm{He}$ thus updates Vitruvius to suit the political and social realities of his circumstances.

In addition to presenting his new-found knowledge in Portuguese for his peers at court (both professional and social), Hollanda also supplied them, through his extensive citations, translations of critical Latin texts. One of Hollanda's most striking claims in Book One of $D a$ Pintura Antiga is that his treatise is the first of its kind in Portugal. ${ }^{11}$ He emphasizes the novelty of his work and characterizes himself as a learned champion for his king, determined to produce from his experience in Italy "something very new and rare". ${ }^{12}$ Encompassing everything that he

\footnotetext{
${ }^{9}$ Hollanda, On Antique Painting, p. 68 ; and Hollanda, Da Pintura Antiga, p. 9, “porque dizem que o saber é só de todos oque em nenhuma alhea patria é strangeiro, nem o que perdido os criados e conheçidos é prove de amigos. Mas oque em todas as cidades ee aceito cidadão, e bom cortesão em qualquer côrte”.

${ }^{10}$ Vitruvius, On Architecture, pp. 2-5. I address the adjustments that Hollanda makes in his translations in Calvillo, 'Reading Pliny'.

${ }^{11}$ Hollanda, On Antique Painting, p. 238; Da Pintura Antiga, p. 344, “per ser o primeiro que em Spanha, nem no reino de Portugal screvesse da pintura, quasi como um dos antigos”.

${ }^{12}$ Hollanda, On Antique Painting, p. 70; Da Pintura Antiga, p. 18. He admits that his treatise is not intended to teach someone how to paint but for those initiated in the art, seeking more knowledge about its theory, and for the patron class, or at least the royal family, whose understanding of art came from "knowing how to do it, for all wisdom and talent and knowledge lies in the comprehension of drawing in painting” (pp. 69-70, and Da Pintura Antiga, pp. 14-
} 17). 
learned in Italy, Hollanda presents his Da Pintura Antiga as a trophy from his "conquest" of Rome, couching his experience in chivalric language. The product of that experience, his text and a collection of highly finished drawings in a bound volume now known as Os Desenhos das Antigualhas, become the spoils of a knight defending the "Princess Painting". ${ }^{13}$ A central component of Hollanda's translation of the art and art theory of Cinquecento and ancient Italy, these drawings functioned as a rhetorically powerful framework for the artist's theoretical project and his role as a cultural agent in Portugal. ${ }^{14}$

This chapter argues that these drawings were conceived to be an intrinsic part of Hollanda's inventive and cultural enterprise; as material evidence of the intellectual riches that he brought back to his court, they parallel the translated content of his text. In keeping with the chivalric representation of a knight returning home from a military campaign, the artist emphasizes his fidelity to his home and sovereign, having resisted the professional opportunities of working in Rome:

The only thing that was always present in my mind was how I might put my art at the service of our lord the King who had sent me there, and I was constantly pondering how I

\footnotetext{
${ }^{13}$ El Escorial, Real Biblioteca del Monasterio de San Lorenzo de El Escorial, MS. 28-I-20. See also Hollanda, On Antique Painting, p. 169, and Hollanda, Da Pintura Antiga, p. 219.

${ }^{14}$ For the visual arts as a means of cultural translation and European conceptions of Italy, a term that Hollanda uses especially in comparison the cultural practices of Portugal and Spain, see Stephen J. Campbell and Stephen Milner J. (eds.), Artistic Exchange and Cultural Translation in the Italian Renaissance City (Cambridge, Cambridge University Press, 2004), pp. 2-3 as a general appraisal; more specifically for translation of Italian culture outside of Italy, see for example Fiamminghi a Roma, 1508-1608. Artistes des Pays-Bas et de la principalité de Liège à Rome (Ghent: Snoeck-Ducaju \& Zoon, 1995) and Earl Rosenthal, 'The Diffusion of the Italian Renaissance Style in Western European Art', Sixteenth Century Journal, 9 (1978), pp. 33-45.
} 
might steal the masterpieces and elegances of Italy and carry them, stolen, away to Portugal for the gratification of the King and the Infantes and the most serene lord, the Infante Dom Luís. I used to say: what fortresses or foreign cities have I not yet got in my book (i.e., the Antigualhas)? What timeless buildings and mighty statues does this city still hold that I have not already stolen from it to carry away, without carts or ships, on thin sheets of paper? ${ }^{15}$

Considering Hollanda's emphasis on knowledge as the one thing that a man carries lightly throughout his travels, the drawings represent material equivalent to the knowledge evidenced in his treatise. Both text and image can be brought to his king and country without warfare or cumbersome transportation; the marvel of this artistic 'translation' comes across in Hollanda's language and contrasts the "eternal position of edifices and the great weight of sculptures" (“edeficios perpetuos e statuas pesadas") with his "thin sheets of paper".

Such translation, Hollanda explains, is neither simple nor without difficulty, but the difficulty is ultimately overcome through Hollanda's judgment and skill. These become apparent in his arrangement of the drawings, which foregrounds his intervention and interpretation. The drawings, like the learning and experience demonstrated in the text of Da Pintura Antiga, are the means by which he translated his knowledge of Italy's cultural riches. That these works

\footnotetext{
${ }^{15}$ Hollanda, On Antique Painting, p. 170. and Hollanda, Da Pintura Antiga, p. 221. "E o que só me era sempre presente era o em que poderia server com a minha arte a El-Rei nosso senhor, que me lá mandara, cuidando sempre comigo, como poderia roubar e trazer a Portugal roubados os primores e gentilezas de Italia, do contentamento de El-Rei e dos Infantes, o do serenissimo senhor o Infante D. Luis. Dezia eu: que fortelezas, ou cidades strangeiras não tenho eu inda no meu livro? Que edeficios perpetuos e statuas pesadas tem inda esta cidade, que lhe eu já não ache o mais raro d'ellas polos meus cadernos riscados"?
} 
represented a valuable contribution to the collections of his contemporaries is demonstrated by the fact that they were in the Escorial by the end of the sixteenth century, moved there after the Spanish annexation of Portugal in $1578 .{ }^{16}$ Ironically, the works that Hollanda boasted were stolen from Italy on paper were just as deftly moved to Spain and the Royal Collection at the Escorial less than 40 years later.

My focus here is to consider Hollanda's presentation of himself as translator of foreign ideals and the way in which the drawings and the text of Da Pintura Antiga communicate the knowledge that he gained and synthesized in Rome. In Portugal, Hollanda's translations of antique and contemporary Italian culture took form in his discussion of modern art theory, such as Alberti's De Pictura, his long citations of Vitruvius and Pliny, and in his arrangement of artistic monuments seen and drawn in Rome. ${ }^{17}$

\footnotetext{
${ }^{16}$ For the history of the album, see Elias Tormo y Monzó (ed.), Os Desenhos das Antigualhas que vio Francisco d'Ollanda (Madrid: Ministerio de Asuntos Exteriores, 1940) and Joaquim de Vasconcellos, Antiguidades da Itália por Francisco de Holanda. Descripção critica dos desenhos do Escurial (Lisbon: Imprensa Nacional, 1896). For a more recent facsimile, see José da Felicidade Alves (ed.), Álbum dos Desenhos das Antigualhas (Lisbon: Livros Horizonte, 1989). See also John B. Bury's catalogue of Hollanda's works (pp. 33-34) and a summary history of the Desenhos in Two Notes on Francisco de Holanda (London, The Warburg Institute, University of London, 1981). For specific drawings, see Deswarte-Rosa's Ideias e Imagens, pp. 55-122; Sylvie Deswarte-Rosa, 'Francisco de Holanda et le Cortile de Belevedere', in Matthias Winner, Bernard Andreae, and Carlo Pietrangeli (eds.), Il Cortile delle Statue: der Statuenhof des Belvedere im Vatikan, Akten des inernationalen Kongresses zu Ehren von Richard Krautheimer, Rome, 21-25 Oktober, 1992 (Mainz: Verlag Philipp von Zabern, 1998), pp. 389-410; Felipe Pereda, ‘Ántigüedades judías y piedad Cristiana: Francisco de Holanda de los Desenhos de El Escorial a las Aetatibus Mundi Imagines', Reales Sitios 156 (2003), pp. 2-15; and Sylvie Deswarte-Rosa, 'Le Rameau d'Or et de Science. "F. Ollandius Apolini Dicavit”, Pegasus. Berliner Beiträge zum Nachleben der Antike 7 (2005), pp. 9-47.

${ }^{17}$ Calvillo, 'Reading Pliny', pp. 263-296.
} 


\section{Documents or Inventions? The Critical Misfortune of Da Pintura Antiga and Os Desenhos}

\section{Antigualhas}

If one takes the fate of the Roman drawings as an example of how Hollanda's method was also in some ways his works' undoing - in the case of the drawings metaphorical trophies literally become war spoils - we might consider the extent to which his choice of Michelangelo and Vittoria Colonna as models for Book Two, the Roman Dialogues, undermined Book One, relegating the treatise to a secondary position in the historiography because of historical interest in the dialogues' interlocutors. The fame that made them exemplary also doomed his work to be read by modern critics as a dishonest or implausible documentary account rather than a rhetorically charged text conceived to reinforce and sometimes enact the ideas of his treatise. ${ }^{18}$ Certainly, Hollanda's decision to participate in the dialogues, rendering them as first person testimony, contributed to the later, negative critical fortune, but Hollanda's reception is mostly a problem of modern historiography and method. ${ }^{19}$ In the last forty years, however, the dialogues

\footnotetext{
${ }^{18}$ Despite stating that his intention was "to demonstrate $[\ldots]$ in the form of a dialogue" the nobility and utility of painting, a statement of purpose that clearly extends beyond the transcription of conversations, Hollanda's dialogues have been criticized for their implausibility. Ironically, it was the degree of their verisimilitude that undermined their rhetorical function to supplement the ideas of the treatise. See Hollanda, On Antique Painting, p. 170 and Hollanda, Da Pintura Antiga, p. 220. The critical misfortune of the treatise is partly demonstrated by the fact that it was first translated into English only in 2013 and is rarely cited by any but specialists. For the history of the dialogues' reception, see Laura Camilla Agoston, 'Michelangelo as Voice versus Michelangelo as Text', Journal of Medieval and Early Modern Studies, 36 (2006), pp. 135-167.

${ }^{19}$ For the documentary form of the Renaissance dialogue, see Virginia Cox, The Renaissance Dialogue (Cambridge, UK: Cambridge University Press, 1992), p. 10, and David Marsh, The Quattrocento Dialogue: Classical and Humanist Innovation (Cambridge, MA: Harvard University Press, 1981). Agoston, 'Michelangelo as Voice', p. 135,
} 
have been more productively understood as rhetorical works based on real persons and ideas, neither chronicling events or conversations nor wholly fabricating the art theory of the $1540 \mathrm{~s}^{20}$

In contrast to his dialogues, Hollanda's drawings in the Escorial have provoked little critical suspicion, even though they also demonstrate the artist's will to interpret and to invent in order to translate his experience in Italy. ${ }^{21}$ Hollanda's book of drawings has likely resisted interpretation because his primary method of invention is in the arrangement of objects or monuments in relationship to one another. They have rarely been the focus of study outside the scholarship on Hollanda, and when they have appeared in studies, the drawings are usually examined as records of the appearance of well-known works of art or architecture circa 1540 [Fig. 15], such as the 'Cleopatra' in the Vatican Belvedere. ${ }^{22}$

has explained the critical rift as being between historians who read the dialogues as if they were a transcript, or a "vestige" of a historical conversation, and those who approach the work as an invention to express the author's ideas.

${ }^{20}$ Many associate this shift in Hollanda's reception with David Summer's discussion in Michelangelo and the Language of Art (Princeton, N.J., Princeton University Press, 1981), pp. 26-27. Even scholars who have been skeptical of artist-philosophers now accept Hollanda's text as attempting to present the ideas of his time through the dialogue form; see his essay, 'Francisco de Hollanda and Art Theory, Humanism and Neoplatonism in Italy' in Hollanda, On Antique Painting, pp. 45-64.

${ }^{21}$ There has been some debate concerning taxonomy. See Sylvie Deswarte-Rosa, 'Francisco de Holanda e le Cortile', pp. 389-390; and Nesselrath, Arnold, 'I libri di disegni di antichità. Tentativo di una tiplogia', in Salvatore Settis (ed.), Memoria dell'antico nell'arte italiana (3 vols., Turin: Einaudi, 1986), III, pp. 87-147.

${ }^{22}$ Deswarte-Rosa's interpretation is an important exception: 'Rome Déchue. Décomposition d'une image de Francisco de Holanda', Monuments et Mèmoires Eugène Piot, 71 (1990), pp. 97-181. See also Elena Calvillo, 'Inventive Translation, Portraiture and Spanish Habsburg Taste', in Piers Baker-Bates and Miles Pattenden (eds.), The Spanish Presence in Sixteenth-Century Italy: Images of Iberia (Farnham, Ashgate, 2015), pp. 175-197, at pp. $180-182$. 


\section{[INSERT FIGURE 15 HERE]}

[CAPTION FOR FIGURE 15:] Figure 15: Francisco de Hollanda, Belvedere Cleopatra, fol. 8v, Os Desenhos da Antigualhas (c. 1540), Ms. 28-I-20, Biblioteca del Real Monasterio de San Lorenzo El Escorial, (c) PATRIMONIO NACIONAL

Because material evidence of these subjects often still exists, most scholars have neither challenged their descriptive veracity nor recognized their inventive component. ${ }^{23}$ If one were to isolate the portraits of the interlocutors in the dialogues of Da Pintura Antiga, the locations of their meetings, and the content of their discussions, only a few passages would seem implausible or invented by Hollanda. Yet, the literary form that arranges these historical figures in historical places and has them enact conversations reinforcing points made in Hollanda's treatise has disposed the modern reader to react negatively to any false or fanciful note. Only recently have scholars recognized that Hollanda embraced his inventions as the tools by which he made his knowledge and arguments vivid to his readers and viewers in Portugal. Thus the aspects of the dialogues that damned their modern reception were the very qualities that demonstrated Hollanda's ability as an authoritative translator. Similarly, his 'thefts' of the monuments and antiquities of Rome and Italy, carried away on thin sheets of paper, are examples of translatio not only for their canonicity but also for their judicious selection and meaningful arrangement.

\section{Reading Pintura Antiga as Cultural Translation}

Hollanda surely chose his characters because they would have been known to the members of his court. Their status as the most illustrious artist and female patron in Rome afforded him an

\footnotetext{
${ }^{23}$ For this failure to see the inventive component of drawings that seem like documentarly studies of monuments, see Cammy Brothers, 'Reconstruction as Design: Giuliano da Sangallo and the "palazo di mecenate" on the Quirinal Hill', Annali di architettura, 14 (2002), pp. 55-72.
} 
opportunity to communicate the most salient aspects of contemporary art theory and patronage. Michelangelo's international reputation by the 1540 s is indisputable, but it is perhaps less obvious that Vittoria Colonna would have been known at Évora or Lisbon. However, she was not only a Colonna, and thus understood as an Imperial ally, but the wife of a d'Avalos, whose clan originated in Spanish Naples. ${ }^{24}$ She was also a widely published poet by 1548 , the completion date of Da Pintura Antiga, and known for her piety. ${ }^{25}$ The friendship between the male artist and the female poet provided Hollanda with a memorable and exemplary platform from which to exhort similar enlightened dialogue in Portugal. The reciprocity and grace that characterize Colonna's and Michelangelo’s creative exchanges also supplied an ideal counterpart to the discussion of an ancient patrons' understanding and estimation of art, introduced in Hollanda's prologue to Book Two and read in Pliny throughout the fourth dialogue. ${ }^{26}$ Finally, that Hollanda seems to have served female members of the Portuguese court should not be overlooked when considering Colonna as his principal representative of the patron class among the interlocutors.

\footnotetext{
${ }^{24}$ For the early adult life of Vittoria Colonna with d'Avalos, see Pierluigi Leone de Castris, 'Kultur und Mäzenatentum am Hof der d'Avalos in Ischia', in Sylvia Ferino-Pagden (ed.), Vittoria Colonna: Dichterin und Muse Michelangelos (Vienna, Skira, 1997), pp. 66-76, and Ippolita di Majo, 'Vittoria Colonna, il Castello di Ischia e la cultura di Ischia e la cultura delle corti’, in Pina Ragionieri (ed.), Vittoria Colonna e Michelangelo, Casa Buonarroti, Florence, 24 May-12 September, 2005 (Florence: Mandragora, 2005), pp. 19-32.

${ }^{25}$ Vittoria Colonna's spirituality is central concern of most scholarship dedicated to her. In the context of Hollanda's dialogues, see Deswarte-Rosa 'Vittoria Colonna und Michelangelo in San Silvestro al Quirinal nach den Gesprächen des Francisco de Holanda', in Vittoria Colonna, pp. 349-373. Deswarte-Rosa has demonstrated an interest in Petrarchan verse at the Portuguese court; see her Ideias e Imagens, p. 74.

${ }^{26}$ For Michelangelo's and Colonna’s creative relationship, see Alexander Nagel, 'Gifts for Michelangelo and Vittoria Colonna', The Art Bulletin, 79 (1997), pp. 647-668.
} 
The other figures who appear as ideal patrons and artists, such as Pope Paul III and the miniaturist Giulio Clovio (Michelangelo's surrogate in the fourth dialogue) were equally well known and probably associated with one another by Hollanda's fellow courtiers. ${ }^{27}$ Vittoria Colonna's support of Clovio's career in Rome, for example, probably contributed to his successful reception at the Imperial courts. ${ }^{28}$ Clovio's miniatures are similar to copies after Michelangelo associated with Colonna in the 1540s, when she received the Florentine's presentation drawings. ${ }^{29}$ Knowledge of Michelangelo gifts to her and her taste for his works could well have reached the culturally informed members of the Portuguese and Habsburg courts. If not, Hollanda supplied a clear portrait of her as an enlightened patron and poet. Through a question posed by her to Michelangelo, Hollanda famously introduces his controversial distinction between Flemish and the Italian art:

"The Painting of Flanders, Signora", the painter answered slowly, "will generally please any devout person more than any Italian painting, which will never cause him to shed a single tear, whereas that of Flanders (will cause him to weep) many; not because of the

\footnotetext{
${ }^{27}$ For Hollanda's conception of the ideal patron, see Calvillo 'Inventive Translation', pp. 180-182.

${ }^{28}$ By the time of Hollanda's treatise, Clovio's works were beginning to be sent as diplomatic gifts prized male and female members of the Habsburg courts. Few survive; see Almudena Pérez de Tudela, 'Documenti Inediti su Giulio Clovio al Servizio della Famiglia Farnese', Aurea Parma, 84, 2 (2000), pp. 280-307; Elena De Laurentiis Accornero, 'Giovanni Battista Castello "Il Genovese”, Giulio Clovio e lo "scriptorium” dell'Escorial', in Piero Boccardo, José Luis Colomer, and Clario Di Fabio (eds.), Genova e la Spagna: opere, artisti, committenti, collezionisti (Milan: Silvana Editore, 2002), pp. 156-165.

${ }^{29}$ While Clovio's works are not copies, most of his cabinent miniatures centre on Michelangelo's designs. How closely copies after Michelangelo’s presentation drawings can be associated with Colonna is unclear; see Bernadine Ann Barnes, Michelangelo in Print (Farnham: Ashgate, 2010), pp. 69-72, and n49 citing a letter that suggests Colonna most valued Michelangelo’s design and did not worry if the work were not by his hand.
} 
vigor and good quality of that painting, but because of the goodness of that devout person. It will appeal to women, especially the very old or the very young, and likewise to monks and nuns, and to some noblemen who are tone-deaf to true harmony". ${ }^{30}$

Colonna's question provided the straw man for Michelangelo's response favoring the design, intellect and idealization of Italian art, but Hollanda and those familiar with his text would have known that she provided a model for the female viewer that was more complicated and informed than that suggested by Michelangelo's response in the dialogue. As Agoston notes, despite polarizing divisions in this passage between intellectual substance (male) and superficial material (female), or good and bad painting, Hollanda's entire work offers a more moderate art theory, one that allows for much of what appears to be rejected in Michelangelo's response. Colonna's own cultural practice, as manifested in her poetry and collection of devotional art, encompassed both the emotional response disparaged in Michelangelo's comments and the intellectual rigor recommended by them, thus providing the female reader or viewer of Hollanda's works with an admirable model of cultivation and artisitic discernment. ${ }^{31}$

\footnotetext{
${ }^{30}$ Hollanda, On Antique Painting, pp. 179-80, and Hollanda, Da Pintura Antiga, pp. 235-236, “A pintura de Frandes, respondeu devagar o pintor, satisfará, senhora, geralmente, a qualquer devote, mais que nenhuma de Italia, que lhe nunca fará chorar uma só lagríma, e a de Frandes mitas; isto não polo vigor e bondade d'aquela pintura, mas pola dondade d'aquele tal devote. A molheres parecerá bem, principalmente ás muito velhas, ou ás muito moças, e assi mesmo a frades e a freiras, e a alguns fidalgos desmuscios da verdadeira harmonia". Agoston addresses the gendered positions of Michelangelo and Colonna in her study 'Male/Female, Italy/Flanders, Michelangelo/Vittoria Colonna', Renaissance Quarterly, 58 (2005), pp. 1175-1219.

${ }^{31}$ Una Romana d'Elia establishes the way in which Colonna's poetry reflects her sophisticated understanding of disegno and colorito; see her 'Drawing Christ's Blood: Vittoria Colonna, Michelangelo, and the Aesthetics of Reform', Renaissance Quarterly, 59 (2006), pp. 90-129.
} 
It is tempting to think that Hollanda's project was partly conceived for his female patrons in Portugal and that his selection of Colonna as a principal interlocutor served this end. That Hollanda fulfilled at least one request of Queen Caterina is testified to by his copying the image of Christ in the Sancta Sanctorum, as reported in both the treatise and the third dialogue of Book Two. ${ }^{32}$ While the passage in the treatise concerns the production of sacred images and the representation of Christ, that in the dialogue ties Colonna, through her interest in ancient sacred images, to queen Caterina and by extension to other pious women at the Portuguese court.

Hollanda's copy of the Lateran image was presumably seen by a privileged handful of the queen's intimates. His appeal to the piety of the women at his court may also be seen in his drawings of religious relics in the Desenhos das Antigualhas. Among the first drawings are the titulus of Santa Croce in Gerusalemme and the column from Solomon's Temple in St. Peter's Basilica, presented in facing pages on folios $4 \mathrm{v}$ and $5 \mathrm{r}$; at the end of the album is the reliquary skull of St. Mary Magdalene at St. Maximin (fol. 48v) seen in Provence on his journey home to Portugal. Hollanda thus brackets the pagan antiquities of Rome and the contemporary works of art in Italy with depictions of sacred objects associated with saintly women: the titulus crucis and the Magdalene relic. Vittoria Colonna showed a life-long devotion to Mary Magdalene, like many women of her station who needed a model of spirituality and chastity in marriage and widowhood. ${ }^{33}$

\footnotetext{
${ }^{32}$ Hollanda reports that he painted this work for "our lady the queen" in On Ancient Painting, p. 119 and 211, n11920 at p. 162; Da Pintura Antiga, pp. 140 and 299. This passage has been discussed by scholars interested in Vittoria Colonna's taste for archaic, cult images; see Alexander Nagel, Michelangelo and the Reform of Art (Cambridge, UK: Cambridge University Press, 2000), p. 75; and Deswarte-Rosa, 'Vittoria Colonna und Michelangelo', p. 363.

${ }^{33}$ Barbara Agosti has emphasized the importance of the cult of the Magdalene for Colonna and the court at Ischia. See her 'Vittoria Colonna e il Culto della Maddalena (tra Tiziano e Michelangelo)', in Vittoria Colonna e
} 
Historical interest in Colonna has perhaps skewed the amount of interest given to the dialogues in comparison to the treatise, but Hollanda's use of Michelangelo as the ideal, learned artist opened his work to the harshest criticism from later scholars who disputed whether Michelangelo could possibly have said what Hollanda presents in the dialogues. ${ }^{34}$ A more nuanced and contextualized examination of Hollanda's theoretical project, however, reveals that he primarily presents Michelangelo as an authoritative interlocutor and historical figure in his texts and in Os Desenhos da Antigualhas. In fact, the elder Florentine artist is surprisingly scarce in Book One's treatise and the Antigualhas, at least in contrast to his vivid presence in the dialogues. One must read and look carefully to find references to Michelangelo, though once found they suggest the extent to which Hollanda's project sought mediate the Florentine's reception in Portugal.

\section{A Defense of the Sistine Chapel Last Judgment}

An example of such mediation, and translation, is Hollanda's critical response to Michelangelo's Last Judgment in the Sistine Chapel, unveiled in 1541 and immediately denounced by critics for its nudity and iconographic complexity. Citing the epic poet Virgil in Chapter XXXII, Hollanda introduces his theme with "Facilis descensu Averni" ("the descent to

Michelangelo, pp. 71-81, at pp. 75 and 81, n21. See also Michael Hirst, Tre saggi su Michelangelo (Florence, Mandragora, 2004); Marjorie Och, 'Vittoria Colonna and the Commission for a "Mary Magdalene” by Titian', in Sheryl E. Reiss and David E. Wilkins (eds.), Beyond Isabella: Secular Women Patrons of Art in Renaissance Italy (Kirksville: MO, University of Missouri Press, 2001), pp. 193-223; and Gigliola Fragnito essays on Colonna’s spirituality, most recently 'Vittoria Colonna e il dissenso religioso', in Vittoria Colonna e Michelangelo, pp. 97105.

${ }^{34}$ For the history of that critical reception, see n18 and Agoston, 'Michelangelo as Voice'. 
Avernus is easy"), and comments, "yet whoever is willing to ponder carefully will find that somber and horrible painting of purgatory and its pains, and the most cruel painting of hell, is very useful in enabling us to descend there in this life". ${ }^{35}$ Noting their utility to the imagination is a standard justification for sacred images. Hollanda's defense of Michelangelo in this section is incremental in its specificity and application to the Sistine Chapel work. He continues by acknowledging the difficulty and creative challenge of Michelangelo's subject:

The admirable and most solemn painting to which at this point I would call the attention of the contemplative and most learned painter is the likeness and most sacred image of the awesome day of judgment, for in this most famous and memorable historia the great master will find much to work on and to ponder, and much more to give others to ponder in his work. And this is the most noteworthy painting that can be seen in this wide earth, and, with its dependent parts, the most memorable. ${ }^{36}$

The emphasis on the noteworthy painter and famous historia would have brought to the readers' minds Michelangelo's recent work, which Hollanda might have seen before he left Rome in 1540, before the painting was officially unveiled.

\footnotetext{
${ }^{35}$ Hollanda, On Antique Painting, p. 123, and Hollanda, Da Pintura Antiga, p. 151, “"Averni”, diz Vergilio. Porém quem o bem quiser considerer, achará que a grave e horrible pintura do purgatorio e suas penas, e a curelissima do infrmo muito compre n'esta vida a ella decer'.

${ }^{36}$ Hollanda, On Antique Painting, p. 123, and Hollanda, Da Pintura Antiga, p. 151. "E a admirable e gravissima pintura que n'este lugar lembro ao contemplative e doutissimo homem que pinta, é a semelhança e sanctissima imagem do spantoso dia do juizo, poque n'esta famosissima e memorable historia tem o grande mestre muitoque trabalhar e consirar, e muito mais que dar a outrem que na sua obra consire, e muito mais que dara a ouatrem que na sua obra consire. E esta é a pintura mais ntavel que sobre este grão mundo pode ser vista, nem a mais dina de memoria com as partes que d'ella dependem".
} 
The use of the word historia in this passage is significant not only because it suggests his knowledge of Alberti's treatise on painting, whose first publication was in preparation when Hollanda was in Rome, but also because it implies the creative, poetic element of the artist's representation of what would have been understood as a historic scene. ${ }^{37}$ Michelangelo’s incorporation of poetic and mythological figures into a sacred history, as Charles Dempsey has shown, was a key component of the most learned criticism against him. ${ }^{38}$ Toward the end of this chapter, Hollanda circles back to the opening reference to Virgil, addressing the devotional utility of representing hell. His language here becomes specific enough to argue that Hollanda is responding to the current criticism:

Thus before his death, the serious painter, if he believes himself capable of doing so, must show other men what they are unable to see while they live; and so he will contemplate and by means of painting will represent the torments and punishments of hell, not merely as the pagans or the poet Virgil painted them, with Acheron, the boatman of the wretched souls,... but far beyond the River Cocytus and Phlegethon, and beyond

\footnotetext{
${ }^{37}$ See Deswarte-Rosa, Ideias Imagens, for Hollanda's likely knowledge of Alberti manuscript.

${ }^{38}$ Charles Dempsey, 'Mythic Inventions in Counter-Reformation Painting', in P.A Ramsay (ed.), Rome in the Renaissance: the City and the Myth (Binghamton, NY: Medieval and Renaissance Texts and Studies, Center for Medieval and Early Renaissance Studies, 1982), pp. 55-75, at 64-65. For the early critical reception of the fresco, see Bernadine Barnes, Michelangelo's 'Last Judgment': the Renaissance Response (Berkeley, CA: University of California Press, 1998); and Melinda Schlitt, 'Painting, Criticism, and Michelangelo's “Last Judgment” in the Age of the Counter Reformation', in Marcia Hall (ed.) Michelangelo's 'Last Judgment' (Cambridge, Cambridge University Press, 2005), pp. 113-148.
} 
that inviolable lake of the Styx,... and beyond Minos the judge...He will paint the cruel chain that binds the damned, which the Gospel calls the Gehena ignis. ${ }^{39}$

Hollanda's point here is not necessarily whole-hearted endorsement of antique images of hell but an exhortation to produce an image that culminates with Christian content and, more important, one whose terrifying effect results in Christian penance and avoidance of sin. His emphasis, however, on the learned and devout artist, one who can marshal both the imagery of Virgil's poetic imagination and the sacred history of the Gospels ultimately lays the foundation for a defense of Michelangelo's work, as long as it also contained scenes that would compel the viewer to avoid $\sin ^{40}$

Oliveira Caetano has recently argued that Hollanda's humanism was quickly outdated in Tridentine-era Portugal. ${ }^{41}$ Equipped with the most current Italian cultural artistic theory, Hollanda somewhat tragically returned to a court that would soon eschew the intellectual liberality of the 1530s. His chapter on representations of hell both defended Michelangelo's epic

\footnotetext{
${ }^{39}$ Hollanda, On Antique Painting, p. 124. See also Hollanda Da Pintura Antiga, p. 152, "Assi que o grave pintor antes de sua morte, se se achar capaz para fazel-o, deve de mostrar aos outros homens aquilo que elles, vivendo não podem ver; e assi contemplará e representará com pintura os tormentos e castigos do inferno não sómente como o pintavam os gentios ou o poeta Virgilio, com Aqueronte, barqueiro das tristes almas...mas muito além do rio Cocyto e Flegeton e além d'aquela lagoa inviolable da Styge...e além do Juiz Mynos...Pintará a cruel cadea que prende aos condenados, a qual o Evangelho chama Gehena ignis".

${ }^{40}$ Though he acknowledging the primacy of sacred texts, Hollanda maintains the richness and utility of poetic texts usually associated with Michelangelo's Last Judgment; see Hollanda, On Antique Painting, pp. 124-125; and Hollanda, Da Pintura Antiga, p. 153. Deswarte-Rosa discusses Hollanda's admiration for this aspect of Michelangelo's intellect and art in Ideias e Imagens, pp. 198-199.

${ }^{41}$ Oliviera Caetano, 'Francisco de Hollanda'.
} 
mode of painting for the Last Judgment and the kind of learning necessary to produce such a work. By the time Hollanda had his work translated into Castilian in 1563, he saw fit to change his emphasis, exchanging "doutissimo" (most learned) with the "devote" (devout), as Alice Sedgwick Wohl has noted. ${ }^{42}$ Hollanda's discussion of epic poetry and emphasis on learning in the context of Christian imagery might be understood to provide a cogent defense to the better known criticisms of Pietro Aretino, who faulted Michelangelo for the difficulty of his imagery, which only a few would understand. Such a defense not only indicates the intellectual and theoretical position taken by Hollanda but also the extent to which he aimed to remain current and informed about Italian art theory. While Michelangelo might seem curiously absent in Book One of Da Pintura Antiga, he is represented in the subjects engaged by the treatise. Hollanda introduces Michelangelo, whether through his work or his persona in the dialogues, as the most important practitioner and authority on matters of art in Italy.

In a similarly indirect way, a passage in dialogue four of Book Two establishes an eschatological metaphor to represent Michelangelo's Last Judgment as the culmination of artistic perfection. An anonymous Roman gentleman conversing with Hollanda, Giulio Clovio, and Valerio Belli calls into question the existence of contemporary Golden Age in Pauline Rome by linking the perfection of Augustan era art with to its temporal and physical proximity to the living Christ:

It was then, certainly, that things existed in their perfection...both in the arts and in warfare,... which had been increasing and rising from the beginning of the world until

\footnotetext{
${ }^{42}$ Hollanda, On Antique Painting, p. 123, translator's note. On the significance of this change of language and Hollanda's need to navigate the culture of Counter-Reformation Spain and Portugal see Elena Calvillo, 'Review of Francisco de Hollanda, On Antique Painting, trans. Alice Sedgwick Wohl (University Park: Pennsylvania State Press, 2013)', http://www.caareviews.org/reviews/2443\#.V_D8ghGoVAQ (accessed 2 May 2017).
} 
that time, and which have been decreasing and declining steadily from the time to this or until our day. And this I believe Divine Providence did because the time was drawing ever nearer in which the perfection of its Marker made Man and God on earth was awaited, for I make bold to claim that never before or since were things at their peak and universal perfection as in the time of Augustus, during which God became incarnate. And similarly, once holy perfection perceived that he had ascended into heaven, it began to retrace its steps and to seek him in heaven. ${ }^{43}$

Following the logic of Hollanda's Roman gentleman, only the second coming of Christ would return the arts to some kind of perfection. Taken with Hollanda's discussion of hell and the epic mode in chapter thirty-two of the treatise, these comments suggest that Michelangelo's Last Judgment promises a return to the artistic perfection of the Augustan era.

Hollanda's engagement with one of the most current and controversial subjects in the world of art demonstrates both his theoretical inclination and his ability to interpret and translate

\footnotetext{
${ }^{43}$ Hollanda, On Antique Painting, p. 224. See Hollanda, Da Pintura Antiga, pp. 319-320 for the full passage, "Então esteveram as cousas, certo, na sua perfeiçao e alto cume, assim nas artes como nas armas, como na nobre piintura,... como em todo o mais valor e dotes que o immortal Deos deu aos homens mortaes, o qual do começo do mundo até então até hoje, ou até os nossos tempos, sempre tornou a vir descend e deminuindo. E isto me parece a mim que fez a Divina Providencia porque se vinha chegando cada vez mais o tempo em que sperava de vêr a perfeição de seu fazedor ser feito Homem e Deos sobre a terra, porque eu me atrevo a sostentar que nem antes nem depois esteveram as cousas tanto no seu sumo, e perfeição universal, como no tempo de Augusto, (p. 320) em o qual Deos encarnou. E assi mesmo como a sancta perfeição o viu ido para o ceo, tornou a desandar o caminho por onde viera, e a se ir buscá-lo ao ceo".
} 
the cultural events of Rome. ${ }^{44}$ Hollanda's informed interpretation of what was at stake with the critical reception of Michelangelo's work and its tenuous position at a moment of great change and anxiety over sacred images presents itself in a layered and highly nuanced way from his defense of pagan poetic imagery in chapter thirty-two of Book One to his discussion of Horace's ut pictura poesis in the third dialogue and the Roman gentleman's eschatological model for the perfection of the arts in the fourth dialogue.

\section{Michelangelo's Presence in Da Pintura Antiga and Os Desenhos Antigualhas}

Hollanda's Michelangelo provided the bar against which one measures artistic and creative success throughout Da Pintura Antiga. Hollanda's use of the greatest living artist as an interlocutor has been somewhat superficially understood as a form of braggadocio, but it would be more productive to understand his presentation of Michelangelo in terms of exemplarity, as with Vittoria Colonna. Given his prominence in the dialogues and his influence in the treatise, one would expect that there would be more drawings after Michelangelo's works in the Antigualhas, yet there are only two figures from the Sistine Ceiling, and relatively minor ones: the Charity (fol.11v) and the Eritrean Sibyl the facing folio 12r. As Deswarte-Rosa has noted, Vittoria Colonna invoked the latter figure in the second dialogue as a witness of God's creation. ${ }^{45}$ Colonna's comment is worth considering because it offers a kind of metaacknowledgment of the absence of Michelangelo's works in both the Hollanda's text and

\footnotetext{
${ }^{44}$ Although the Roman Dialogues are no longer understood as simple reportage, much work remains to identify the points of intersection between the theory laid out in Book One and articulated by the interlocutors in Book Two.

${ }^{45}$ Deswarte-Rosa, Ideias e Imagens.
} 
collection of drawings from Italy. When, after listing all the noteworthy modern works to be seen in Italy, Michelangelo excludes Rome, Colonna explains his omission:

Do you not notice, Messer Francisco, how Messer Michael refrained from speaking about Rome, the mother of painting, in order not to mention his own works? Now, since he was unwilling to do so because he was performing his obligation, let us not fail to perform ours in order to confound him the more, for when one is to treat of famous painting, there is no other of any value except the source from which they all derive and proceed. This is at the head of the source of the church, I mean at Saint Peter's in Rome, a great ceiling in fresco, with its circuit and lunettes and a wall, where in a divine manner Michelangelo encompassed how God first created the world, in separate historie, together with many images of Sibyls and figures of the most artful decorativeness and skill. And what is extraordinary is that, while he has done nothing more than this work, which he still has not completed having begun it when he was a young man, the work of twenty painters together is contained there on that single ceiling. ${ }^{46}$

Michelangelo's work on the ceiling parallels the vastness of Creation itself. An attempt to reproduce it or any of Michelangelo's work might have compromised Hollanda's authorial and artistic agency and authority. Michelangelo's presence is thus contained to the role of cultural authority and fellow interlocutor.

Hollanda's commitment to present Michelangelo as a learned and illustrious man is nevertheless clear from the verisimilitude of the dialogues and the specific way in which he appears in the drawings. Michelangelo first appears at the beginning of the album in profile

\footnotetext{
${ }^{46}$ Hollanda, On Antique Painting, p. 188; also see Hellmut Wohls notes identifying the Eritrean Sibyl and the reference to the painting of the still-in-progress Last Judgment.
} 
portrait facing Paul III [Figgs. 16 and 17], his powerful patron and the pope throughout the writing of Da Pintura Antiga.

\section{[INSERT FIGS. 16 AND 17 HERE facing each other in the same order]}

[CAPTION FOR FIG. 16:] Figure 16: Francisco de Hollanda, Portrait of Paul III, fol. 1v, Os Desenhos da Antigualhas (c. 1540), Ms. 28-I-20, Biblioteca del Real Monasterio de San Lorenzo El Escorial, (C) PATRIMONIO NACIONAL

[CAPTION FOR FIG. 17:] Figure 17: Francisco de Hollanda, Portrait of Michelangelo, fol. 2r, Os Desenhos da Antigualhas (c. 1540), Ms. 28-I-20, Biblioteca del Real Monasterio de San Lorenzo El Escorial, (C) PATRIMONIO NACIONAL

As the next section will address, the pairing itself demands interpretation and is a key mechanism of Hollanda's translation of ancient and contemporary art. What ideally puts Michelangelo on equal footing with the Farnese pope is suggested by the dynamic between interlocutors in Book Two's dialogues and developed specifically in the context of portraits in Hollanda's treatise on portraiture, Do tirar polo natural, completed in January of $1549 .{ }^{47}$ The artist in all of Hollanda's work, textual and visual, is knowledgeable and valuable to his patron, able to converse and teach, theorize and practice. Michelangelo next appears in the visual representation of Hollanda's stay in Rome as a person conversing about art. We see him with Hollanda standing beside the colossal sculpture now identified as the muse Melpomene, once in the Palazzo della Cancelleria. His presence is performative; as in the dialogues, he and Hollanda guide the viewer in his or her discussion of the works of art presented for consideration.

\footnotetext{
${ }^{47}$ For the influence of this treatise, see Joanna Woodall, Antonis Mor: Art and Authority (Zwolle: Waanders, 2007), pp. 9-44 and pp. 235-60; also see Calvillo, 'Inventive Translation', pp. 180-181, and Deswarte-Rosa who notes the equality suggested by their presentation, Ideias e Imagens, p. 82 .
} 


\section{Francisco de Hollanda's Roman Triumph, Os Desenhos da Antigualhas}

The drawing of the Cancelleria colossal muse on folio 10 [Fig. 18] faces Hollanda's drawing on folio 9v of the ancient Laocöon [Fig. 19], then installed as his inscription indicates in the garden of the Vatican: ROMAE IN HOR/TIS PONTIFICVM/ DIGNISSIMA SIMULACRA LAO/CHEHONTIS REPERTA IN DOMO TITIV.

\section{[INSERT FIGS. 18 AND 19 HERE, facing each other in the same order]}

[CAPTION FOR FIG. 18:] Figure 18: Francisco de Hollanda, Muse Melpomene, fol. 10r, Os Desenhos da Antigualhas (c. 1540), Ms. 28-I-20, Biblioteca del Real Monasterio de San Lorenzo El Escorial, C PATRIMONIO NACIONAL

[CAPTION FOR FIG. 19:] Fig. 19: Francisco de Hollanda, Laocoön, fol. 9v, Os Desenhos da Antigualhas (c. 1540), Ms. 28-I-20, Biblioteca del Real Monasterio de San Lorenzo El Escorial, (C PATRIMONIO NACIONAL

Hollanda's provision of the location where the sculpture was found is the link that ties the two sculptures together as facing pages. Both sculptures are tied to Michelangelo's first years in Rome. The colossal sculpture of the Melpomene, which was identified as either Minerva or Ops in the Renaissance, was installed in the Palazzo della Cancelleria, or the Palazzo di San Giorgio as Hollanda's inscription notes, in the 1490s when the palace was occupied by Michelangelo's first patron in Rome Cardinal Raffaele Riario. ${ }^{48}$ The Laocöon, in turn, would have been associated with Michelangelo by virtue of its discovery and identification in 1506, when Giuliano da Sangallo and Michelangelo recognized it as the work described in Pliny's Natural History. ${ }^{49}$ The discovery and Michelangelo's association with the work was surely the stuff of

\footnotetext{
${ }^{48}$ For the first record of the sculpture, see Phyllis Pray Bober and Ruth Rubinstein, Renaissance Artists and Antique Sculpture (London: Harvey Miller Publishers, 1986), n39, pp. 79-80.

${ }^{49}$ See Hans H. Brummer, The Statue Court in the Vatican Belvedere (Stockholm: Alquist and Wiksell, 1970); Matthias Winner, 'Zum Nachleben des Laokoon in der Renaissance', Jahrbuch der Berliner Museen, 16 (1974), pp.
} 
legend by the time that Hollanda arrived in Rome, and I would argue that his pairing of these works meant to draw a parallel between Michelangelo's first exposure to the antiquities of Rome and that of our author, who returned to Portugal able to introduce the viewers of his drawing collection and readers of his text to the works that Michelangelo seems to show him. Hollanda effectively becomes Michelangelo to his viewer's Francisco in the drawing. This particular pair of drawings may offer an explanation for the almost complete absence of drawings after Michelangelo's works in Rome. In 1559, Boissard reported that Michelangelo advised artists to look upon the miracle of the Laocoön and seek to grasp its genius rather than try to imitate it. Hollanda's treatise and dialogue repeatedly emphasizes the importance of understanding and discussing works of art. His decision to supply his King, fellow courtiers, and artists with a primarily textual account of Michelangelo as a knowledgeable and contemplative artist privileged the ideas and intellect of the great artist's work. In doing so, Hollanda mediated and exerted greater control over the Portuguese reception of Michelangelo's theory and practice.

The mechanisms at work in folios 9v (the Laocoön) and 10 (the Melpomene) also shed light on how Hollanda translated for his viewers the experience of ancient and contemporary Rome. The way in which he organized his drawings in typological pairs challenged viewers either to draw appropriate connections through their knowledge of the works or to learn about them through Hollanda's interpretive arrangement, a kind of curating of sculptural and thematic exempla. His first pairings suggest his command and understanding of different modes of representation, from naturalistic portraits of the historical men, fols. 1v and 2, [Figs. 16 and 17]

83-121; Phyllis Pray Bober and Ruth Rubinstein, Renaissance Artists and Antique Sculpture, (London: Harvey Miller Publishers, 1986), pp. 152-155, n121. For Francesco da Sangallo's letter to Vincenzo Borghini, see Sonia Maffei and Salvatore Settis (eds.), Laocoonte: fama e stile (Rome: Donzelli, 1999), pp. 110-111. 
to allegorical personifications of Rome of Rome Triumphant and Rome Defeated. ${ }^{50}$ Hollanda's selection and arrangement of works make a strong claim for his artistic and intellectual discernment and his ability to convey_or translate--the most canonical monuments of ancient Roman architecture [Figs. 20 and 21] and antique sculpture [Figs. 15 and 22]. ${ }^{51}$

\section{[INSERT FIGURES 20 and 21]}

[CAPTION FOR FIGURE 20:] Figure 20: Francisco de Hollanda, Colosseum fol. 5v, Os Desenhos da Antigualhas (c. 1540), Ms. 28-I-20, Biblioteca del Real Monasterio de San Lorenzo El Escorial, C PATRIMONIO NACIONAL

[CAPTION FOR FIGURE 21:] Figure 21: Francisco de Hollanda, Pantheon fol. 6r, Os Desenhos da Antigualhas (c. 1540), Ms. 28-I-20, Biblioteca del Real Monasterio de San Lorenzo El Escorial, (C PATRIMONIO NACIONAL

While some pairs such as that of the Colosseum and Pantheon are obvious in their typology, others seem intended to make his viewers work harder to understand his presentation of certain monuments. If the viewer might admire his ability to 'restore' the Colosseum and Pantheon with pen, ink, and gouache, he or she might also experience the artist's wonder and inspiration before the sculptures of Cleopatra - now identified as Ariadne - and Apollo in the Belvedere. Sylvie Deswarte-Rosa has noted Hollanda's witty and creative acknowledgment of

${ }^{50}$ Calvillo, 'Inventive Translation', p. 186.

51 The purpose of Hollanda's arrangement of the drawings into pairs is open to debate; what is clear is that he had access to annotate them well into the 1560 s, since his portrait of Michelangelo bears an inscription marking the date of the artist's death. A recent study of these drawings and Hollanda's later De Aetatibus Mundi Imagines (Madrid, Biblioteca Nacional de España, MS. S. XVI) has also interpreted these works in the context of Hollanda's intellectual ambition. See Maria Berbara, "Nascentes Morimur”: Francisco de Holanda as Artist, Reader, and Writer', in Heiko Damm, Michael Thimann, and Klaus Zittel (eds.), The Artist as Reader: on Education and NonEducation in Early Modern Europe (Leiden, Brill, 2013), pp. 387-419. 
the effect of the Apollo Belvedere on him (Fig. 23 detail of Fig. 22), inserting in the laurel leaves at the god's left foot: F. O L L A N D I V S A P O L IN I D I C A V I T. ${ }^{52}$

[INSERT FIGURES 22 AND 23 HERE facing each other on the same page]

[CAPTION FOR FIGURE 22:] Figure 22: Francisco de Hollanda, Apollo Belvedere, fol. 9r, Os Desenhos da Antigualhas (c. 1540), Ms. 28-I-20, Biblioteca del Real Monasterio de San Lorenzo El Escorial, (C) PATRIMONIO NACIONAL

[CAPTION FOR FIGURE 23:] Figure 23: Francisco de Hollanda, Detail of Figure 8 Apollo Belvedere, fol. 9r, Os Desenhos da Antigualhas (c. 1540), Ms. 28-I-20, Biblioteca del Real Monasterio de San Lorenzo El Escorial, (C PATRIMONIO NACIONAL

The facing page drawing of the Belvedere Cleopatra/Ariadne mirrors this theme of inspiration by presenting the sculpture as a nymph of the garden font, through whose waters the young Hollanda runs his hand. ${ }^{53}$ Hollanda expected an engaged viewer and interlocutor in future 'dialogues' generated from his translated and stolen works. His album is part curated gallery and part academy; it is at once a cultural record, product and catalyst.

\section{Reading the Os Desenhos Antigualhas}

The cognitive skill that recognizes typologies requires breadth of knowledge and the ability to make educated comparisons. Hollanda's typological arrangement of works of art and architecture demonstrates his knowledge and experience, stimulates and rewards that of his peers, and supports the less learned, or practiced viewer. This is partly accomplished by the documentary aspect of these drawings, especially the inscriptions that Hollanda took great care to provide. Not

\footnotetext{
${ }^{52}$ Deswarte-Rosa, 'Le Rameau d'Or et de Science'.

${ }^{53}$ Calvillo, 'Reading Pliny', pp. 288-289; see n75 for relevant bibliography on the nymph as a creative spirit associated with academic gatherings in Renaissance Rome.
} 
only do they suggest Hollanda's abilities in Latin and humanist perspective, they also suggest first-person testimony. The facing-page pairs present objects and monuments to be learned or recognized, be they the columns of Trajan and Antonine, the Quirinal Dioscuri or the frescoes of Raphael in the Vatican. Sometimes these connections seem intended to prompt very specific associations, such as the copy of Raphael's fresco of Hanno the Elephant, which was a gift from King João III to Leo X, facing the watercolor copy of frescoed pilasters all'antica in Raphael's Loggia for the same pope, both considered marvels of Leonine Rome. Other sets of pages, such as the Quirinal Dioscuri or the aforementioned columns hardly seem typological, since by their installation, object type, or subject they were already pairs. If one considers the mechanisms that Hollanda implemented to insure a visual and intellectual comparison, however, a better understanding of the exercise emerges.

One such device is the way in which Hollanda utilized inscriptions across pages to enforce a way of looking, so that the reader must leave the left, verso, page and continue reading the inscription on the right facing page before moving back and down the left page to continue the next line of text; this is most profitably seen in the pages representing the Trophies of Marius [Figs. 24 and 25] and the facing pages of antique masks found in Rome that follow on folios 15v and 16.

\section{[INSERT FIGURES 24 AND 25 HERE]}

[CAPTION FOR FIGURE 24:] Fig. 24: Francisco de Hollanda, Trophies of Marius, fol. 14v, Os Desenhos da Antigualhas (c. 1540), Ms. 28-I-20, Biblioteca del Real Monasterio de San Lorenzo El Escorial, @ PATRIMONIO NACIONAL

[CAPTION FOR FIGURE 25:] Fig. 25: Francisco de Hollanda, Trophies of Marius, fol. 15r, Os Desenhos da Antigualhas (c. 1540), Ms. 28-I-20, Biblioteca del Real Monasterio de San Lorenzo El Escorial, $\odot$ PATRIMONIO NACIONAL 
The reader must combine TROPHEA C. MARII SIC RO on folio 14v with MAE MARMORE SCVLPTA on folio 15 , then return to folio $14 \mathrm{v}$ to continue reading DE TRIVMPHO CIMBRI that is completed by CO ERECTA on folio 15. Forcing the reader's/ viewer's eye to move between pages to complete Hollanda's inscription compels a visual comparison between the two sculptural groups. Such an exercise prompts the reader/viewer to note the differences between the two and to marvel at the detail achieved by Hollanda's skill. This is all the more striking and seemingly purposeful when one considers that Hollanda has inserted his own figure on folio 15. These figurative appearances in the Antigualhas elucidate the scale of the monuments, but as miniature self-portraits they also amplify the authority of Hollanda's testimony and the performative, heuristic function of the drawings. ${ }^{54}$

Reading is thus a central component of Hollanda's method. In the case of the drawings, the visual mode of reading overlays and reinforces that of comparing works of art and architecture. No doubt, on the most basic level, the inscriptions supply the viewer with information about the works and their locations. But, as we have seen, the inscriptions also provide clues to identify the theme or typology connecting the works, whether it be a reference to Michelangelo's own early years in Rome or the nature of divine inspiration in a locus amoenus such as the Vatican Belvedere. I have previously argued that Hollanda's long citation of Pliny's Natural History in the fourth dialogue of Book Two also confronted his reader with a kind of meta-reading where the text of the dialogue becomes the interlocutors reading Pliny. In this case, his characters perform the exercise both prescribed and made possible by Hollanda's work, since there was no published vernacular translation of the Natural History in sixteenth-

\footnotetext{
${ }^{54}$ Calvillo, 'Reading Pliny', pp. 285-290.
} 
century Portugal..$^{55}$ The visual mechanisms implemented by the pairs of drawings in the Desenhos da Antigualhas function in a similar way, using the act of reading an inscription to force the eye to move between pages and compare objects deemed worth of study. This physical movement parallels the cognitive exercise of making connections between two things, so that reading underscores the process of discovery made possible through Hollanda's inventive linking of inscriptions, monuments and sculptures. Although the objects themselves are not the artist's invention, his presentation of them to the Portuguese court represents his triumphant return, each set of images bearing the spoils of his journey. ${ }^{56}$

Hollanda's highly finished, annotated and arranged drawings provide an interpretative counterpart for his long citations of Pliny and Vitruvius. In the case of Pliny's text, the conversations of the dialogue guide the reader to consider certain themes such as the value of painting and the importance of learned discussion, while the enacted reading of Pliny simultaneously forces and equips the reader to engage an important cultural source. Another

\footnotetext{
${ }^{55}$ As Oliveira Caetano notes, there was at least a manuscript by Francisco de Monzón, a chapter of his unpublished second volume of Espejo del principe Christiano, containing passages from Book Thirty-five of Pliny's Natural History, the book that addressed ancient painting and thus the book presented as a reading in Hollanda's fourth dialogue; see Oliveira Caetano's 'Francisco de Hollanda', pp. 32, 44, and n95 that provides the manuscript information (Lisbon, Arquivo Nacional da Torre do Tombo, MS. 618).

${ }^{56}$ Mantegna's Triumphs provide a similar if more inventive precedent. See Stephen J. Campbell, 'Mantegna's Triumph: the Cultural Politics of Imitation 'all'antica' at the Court of Mantua, 1490-1530', in Stephen J. Campbell (ed.), Artists at Court: Image-making and Identity, 1300-1550 (Chicago: University of Chicago Press, 2004), pp. 91-219.
} 
extensive citation of Vitruvius in chapter seventeen of Book One, "Of the Proportion of the Body", serves a similar function. Hollanda characterizes Vitruvius's passage on this subject as the best source:

Here we shall speak of the symmetry and measure of the rational creature, according to Marcus Vitruvius's very judicious examination; and I shall not be like some moderns who, misled by I know not what, wanted to create novelty in a matter that is so certain and well known...But let us use that master's own words. ${ }^{57}$

The passages that follow this introduction are direct citations from Book Three, chapter one of De Architectura. Hollanda's treatise might have provided, as it had for the Natural History, a vernacular translation when none yet existed. A note in Pedro Nunes's dedication of $D e$ Crepusculis (1541) indicates that he had begun a translation of Vitruvius for King João III. André Resende also seems to have been working on a translation of at least a part of De Architectura, and as both Deswarte-Rosa and Margarida Tavares da Conceiçião have noted, several editions of Diego de Sagredo's Medidas del Romano were published in Lisbon in the 1540s. ${ }^{58}$ Hollanda's decision to begin his own prologue to Book One of Da Pintura Antiga by citing extensively, and thus translating, one of Vitruvius's prologues demonstrates the timeliness of his project and his ambition to rival Nunes and Resende, or at least participate in the same humanist activity. Having returned from Rome with direct knowledge of ancient and

\footnotetext{
${ }^{57}$ Hollanda, On Antique Painting, p. 99. See also Hollanda, Da Pintura Antiga, p. 102.

${ }^{58}$ See Deswarte-Rosa, Ideias e Imagens, pp. 168-71; and Margarida Tavares da Conceiçião, 'Translating Vitruvius and Measuring the Sky: on Pedro Nunes and Architecture', Nexus Network Journal, 13 (2011), pp. 205-220; at pp. 211 and 218 n22 she cites Nunes' mention of having begun a translation requested by King João III in his dedication of De crepusculis (date October 1541).
} 
contemporary art and architecture and recent exposure to the theoretical interests reflected in the editions of Alberti's De Pictura and Vitruvius's De Archtiectura, Hollanda re-entered the Portuguese court with a great deal to share. ${ }^{59}$ Whether we think of him as a bold young Dinocrates, from the prologue of Book Two of Vitruvius's treatise, or as a figure closer to Aristippus from Book Six, Hollanda's translation of ancient texts and monuments, on thin sheets of paper, positioned him to be "a good courtier at any court". 60

\footnotetext{
${ }^{59}$ Hollanda's exposure to Italian art theory and probable knowledge of several publications is emphasized by Deswarte-Rosa, Ideias e Imagens, pp. 74, 168-171, and 197. Also see Hope's more skeptical assessment of Hollanda's theoretical fluency in 'Francisco de Hollanda and Art Theory'.

${ }^{60}$ Hollanda, On Antique Painting, p. 68; Da Pintura Antiga, p. 9.
} 
CHAPTER 6

\title{
Authors, Translators, Printers: Production and Reception of Novels between Manuscript and Print in Fifteenth-Century Germany
}

\author{
Albrecht Classen
}

The present chapter examines the intriguing evidence for collaboration among German 'authortranslators' and printers during the fifteenth century, which deeply reflected the changing conditions for production of literature. The aim is not to analyse specific comments made by printers; they tended to approach their task from a technical, or marketing, point of view, and for this reason they left hardly any traces in writing concerning their work. In most cases, translators stated only their names, the location (city) of the print shop in which they worked, and the year in which each of their works was published.

Nonetheless, available data about first editions and reprints produced in Germany between the fifteenth and early seventeenth centuries sheds light on conditions that helped to shape the commercial book market and reading interests of the period, as well as the success of individual titles over time. By the late fifteenth and early sixteenth centuries, the dominant reading material for lay audiences was the prose novel, which the present chapter takes as a case study to examine collaboration among translators, or rather author-translators, and printers. In some instances, we learn of a patron requesting that a particular work be rendered from French into German. In others, a literary-minded individual set himself or herself the task of translating into German a novel that was first composed in Latin or Italian. Not every text was printed immediately; sometimes decades would pass until a wealthy patron commissioned a printer to publish a translated or 'original' novel. The term 'original' is used here to designate literary texts 
that were not explicitly and openly based on a foreign-language source, and which were presented as having been created for the first time in German.

Until the early fifteenth century, virtually all German secular narratives were written in verse (romance). In the course of time these were replaced by prose versions (novels). Only in a few cases did the authors of these novels invent 'new' stories; in most instances they simply relied on medieval romances, and variously translated or imitated them for their own audiences. Hence the use of the term 'author-translator'. Sometimes printers assumed the task of imitation and translation themselves. At other times creative individuals translated or wrote the texts themselves, and subsequently handed them over to the printers.

\section{Novels in Medieval and Early Modern Germany: Imitation and Translation}

Throughout the high and late Middle Ages, German courtly poets and authors were mostly writing works that can be described as a response to narratives already in circulation, being inspired by romances originally created by their French and Dutch predecessors. For instance, Hartmann von Aue translated and imitated the two famous romances Erec and Yvain written by Chrétien de Troyes - making substantial additions, and moulding the material for his own purposes when composing his Erec (ca. 1170) and Iwein (ca. 1200). The same can be claimed for Wolfram von Eschenbach (Parzival, ca. 1205) or Gottfried von Straßburg (Tristan, ca. 1210). ${ }^{1}$ By contrast, when writing his Daniel von dem Blühenden Tal (ca. 1215), Der Stricker (the pseudonym of an otherwise anonymous Middle High German poet) pursued his own path, creating a narrative motif based on the Arthurian myth. Rudolf von Ems followed a similar

\footnotetext{
${ }^{1}$ Joachim Bumke, Die romanisch-deutschen Literaturbeziehungen im Mittelalter. Ein Überblick (Heidelberg: Winter, 1967).
} 
approach with his Der guote Gerhart (ca. 1220), which also proves to be unique in its motif, thematic orientation, and plot. However, in both instances a careful analysis reveals the German writer's imitation of a variety of sources. ${ }^{2}$ Even so, while imitation was always based on earlier materials, as in the case of Konrad von Würzburg's Partonopier und Meliur (ca. 1280), the critical question throughout medieval literature was not 'what' was imitated, but 'how' it was rendered in the new version. ${ }^{3}$ Several cases are known in which a medieval poet fabricated a source to prove that he had relied on an authoritative literary work and was thus justified in presenting a new version of the start text. Wolfram von Eschenbach, for instance, intriguingly claimed to have learned about the Holy Grail from a Provençal man named Kyot. Kyot had discovered the account of the mystical Grail from the Syrian Flegetanis, who in turn had found it written in the stars. ${ }^{4}$

\footnotetext{
${ }^{2}$ In the case of Rudolf von Ems's Der guote Gêrhart (ca. 1220), for instance, the basic plot can be traced back to the Judeo-Arabic collection of tales by the twelfth-century Tunisian Rabbi Nissim, as unlikely as this might sound. See the introduction to Albrecht Classen, An English Translation of Rudolf von Ems's 'Der guote Gêrhart' (Newcastle Upon Tyne: Cambridge Scholars Press, 2016).

${ }^{3}$ Max Wehrli, Literatur im deutschen Mittelalter: Eine poetologische Einführung (Stuttgart: Reclam, 1984), pp. 95113; Douglas Kelly, The Art of Medieval French Romance (Madison: University of Wisconsin Press, 1992), pp. 32 93; Armin Schulz, Erzähltheorie in mediävistischer Perspektive. Studienausgabe (Berlin and Boston: Walter de Gruyter, 2015), pp. 123-124 (with the relevant research literature on this topic). For the pan-European dimension of Partonopier und Meliur, see the contributions to Catherine Hanley, Mario Longtin, and Penny Eley (eds.), Partonopeus in Europe: An Old French Romance and Its Adaptations (Binghamton: The Center for Medieval and Renaissance Studies, 2004).

${ }^{4}$ Albrecht Classen, ‘Noch einmal zu Wolframs ‘spekulativer’ Kyôt -Quelle im Licht jüdischer Kultur und Philosophie des zwölften Jahrhunderts', Studi medievali, 46 (2005), pp. 281-308.
} 
Created since the thirteenth century, Old Norse literature (not the Sagas) was mostly generated through translations from continental medieval texts. Similarly, much of Old French literature was deeply influenced by Latin literature. Translation of a romance from French into German; from Dutch into German; from Italian into English, or from Latin into many different vernaculars - later at times also from a vernacular into Latin (for example Herzog Ernst) — was the modus operandi in the Middle Ages. This practice continued well into the fifteenth and sixteenth centuries, whereas the situation appears to have changed considerably once the early modern book market created quite different conditions for writing and reading, and the centres of literary production moved away from the courts to the urban circles. ${ }^{5}$

\footnotetext{
${ }^{5}$ This phenomenon has been studied already from a range of perspectives; see, for instance, Kathleen Cawsey and Jason Harris (eds.), Transmission and Transformation in the Middle Ages: Texts and Contexts (Dublin: Four Courts, 2007); Laura H. Hollengreen and Laura Holden (eds.), Translatio or the Transmission of Culture in the Middle Ages and Renaissance: Modes and Messages (Turnhout: Brepols, 2008); Emma Campbell and Robert Mills (eds.), Rethinking Medieval Translation: Ethics, Politics, Theory (Cambridge: D. S. Brewer, 2012); Federico M. Federici and Dario Tessicini (eds.), Translators, Interpreters and Cultural Negotiators: Mediating and Communicating Power from the Middle Ages to the Modern Era (New York: Palgrave Macmillan, 2014); Elizabeth Dearnley, Translators and Their Prologues in Medieval England (Woodbridge UK: D. S. Brewer, 2016); Pieter De Leemans and Michèle Goyens (eds.), The Medieval Translator: Translator and Authority (Turnhout: Brepols, 2016). For the Latin version of the Middle High German Herzog Ernst see Peter Christian Jacobsen and Peter Orth (eds.), Gesta Ernesti ducis: Die Erfurter Prosa-Fassung der Sage von den Kämpfen und Abenteuern des Herzogs Ernst (Erlangen: Universitätsbund Erlangen-Nürnberg, 1997). For a discussion of the translation process determining medieval German literature, see, for instance, Joachim Bumke, Die romanisch-deutschen Literaturbeziehungen; see also Marcel Krings and Roman Luckscheiter (eds.), Deutsch-französische Literaturbeziehungen: Stationen und Aspekte dichterischer Nachbarschaft vom Mittelalter bis zur Gegenwart (Würzburg: Königshausen \& Neumann, 2007).
} 
In the pre-modern German tradition, two major texts can be described as 'original': the anonymous Fortunatus (first printed in 1509), and the prose novel - a problematic term in this case — of the Historia von D. Johann Faustus (1587). These works inspired several later vernacular translators. The Fortunatus and Faustus are to be considered two exceptions that confirm German courtly literature of the period as mostly on the receiving end of narratives already in circulation. Revealingly, neither Fortunatus nor Faustus falls into the category of courtly romances or prose novels; they specifically targeted audiences interested in the magical arts, the imaginary, and the miraculous. The former consists first of the protagonist's biography and experiences of magic that make possible travels across most of the then known world; after his death his sons abuse the magical objects and suffer decline and death. Faustus, by contrast, deals with the hero's quest for knowledge, which the Devil provides in return for the hero's soul. Numerous entertaining episodes are also included, resulting in a rather mixed genre.

Of course the establishment of Johann Gutenberg's printing press around 1450 transformed the world of literature, and gave a considerable advantage to the literary market in Germany, which garnered technical superiority over the rest of the world. ${ }^{6}$ Although not contingent upon the invention of metal moveable type, the production of German early prose novels developed at the same time. This genre was more easily printed and, from a literary point of view, simpler to read, while still addressing more or less the same value concepts and themes,

\footnotetext{
${ }^{6}$ Martina Backes, Fremde Historien: Untersuchungen zur Überlieferungs-und Rezeptionsgeschichte französischer Erzählstoffe im deutschen Spätmittelalter (Tübingen: Max Niemeyer, 2004), p. 177.
} 
such as problems and conflicts within the courtly world. As a result, prose novels became some of the most popular printed materials sold via the early modern German book markets. ${ }^{7}$

\section{Translations and 'Originals': A Survey of German Printed Novels}

As in previous centuries, the concept of translation was not openly discussed in fifteenth-century Germany - especially because translation was commonly regarded as a normal activity, and because the major authors belonged to upper ranks within the aristocracy, and thus tended to be multilingual, and operate on an international level. ${ }^{9}$ Whether medieval or early modern, however, the translators inventively adapted their start texts to the target culture. As long as the new authors or translators referred to the authority of their source or sources, all cultural expectations were met. The challenge of eliciting and sustaining reader interest was up to the 'translatorauthor', as several examples indicate, whether in the case of verse romances or of prose novels.

\footnotetext{
${ }^{7}$ Bodo Gotzkowsky, 'Volksbücher': Prosaromane, Renaissancenovellen, Versdichtungen und Schwankbücher. Bibliographie der deutschen Drucke (2 vols., Baden-Baden: Valentin Koerner, 1991); Jan-Dirk Müller (ed.), Romane des 15. und 16. Jahrhunderts (Frankfurt: Deutscher Klassiker Verlag, 1990); Albrecht Classen, The German Volksbuch. A Critical History of a Late-Medieval Genre (Lewiston, NY: Edwin Mellen Press, 1995).

${ }^{9}$ See the contributions to Albrecht Classen (ed.), Multilingualism in the Middle Ages and Early Modern Age: Communication and Miscommunication in the Premodern World (Berlin and Boston: Walter de Gruyter, 2016). The question of what was translated from the various European languages into German and for what reason is rarely discussed; see, for instance, the contributions to Renate Blumenfeld-Kosinski, Luise von Flotow, and Daniel Russell (eds.), The Politics of Translation in the Middle Ages and the Renaissance (Ottawa: University of Ottawa Press, 2001). For a contrasting approach, see the studies in Balázs J. Nemes and Achim Rabus (eds.), VermittelnÜbersetzen - Begegnen: Transferphänomene im europäischen Mittelalter und in der Frühen Neuzeit. Interdisziplinäre Annäherungen (Göttingen: Vandenhoeck \& Ruprecht, 2011).
} 
Sometimes the original and the new version were almost identical, but more often than not the newly adapted versions developed the source narratives' theme or motif in an inventive manner. As discussed below, several of these adaptations were translations from French, Italian, or Latin into German. Curiously, no German versions from English or Spanish texts have been found. Evidence further suggests that no text from the Scandinavian language area was ever translated into late medieval German. Finally, there are also prose novels that were created independently, without a basis in any non-German or medieval German model.

Apart from Fortunatus and Historia D Johann Faustus, printers presented only a few other late medieval novels as having been composed for the first time by German authors. In spite of such a rubric, the themes of these few novels tended to be very similar to those of other novels available in Europe. This is extremely important for the history of German literature, because this corpus of text originated in the German language and can be identified as autochthonous. Such 'original' prose novels include Alexander von Metz, first printed in 1493, and first composed as a balladic song. This work features a husband and wife who demonstrate great loyalty to one other after the husband is taken prisoner by a heathen king. The wife disguises herself as a monk who performs music and thus frees her husband. Alexander von Metz became particularly popular in the sixteenth century (printed in 1500, 1520, 1530, again in 1530, 1543, ca. 1545, ca. 1550, 1560/1570, 1550/1591, ca. 1570, and 1570/1580).

Other 'original' prose novels can be outlined as follows. Barbarossa, printed in 1519, a work containing various accounts of the life of Emperor Frederick I, which are also merged with those from the life of his grandson, Frederick II. Georg Messerschmidt's Brissonetus from 1541, which traces the life and adventures of the knight Brissonetus from Genoa, and includes didactic features concerning the ideal lifestyle of a young nobleman. The Wagnerbuch, by Fridericus 
Schotus Tolet (a pseudonym) is a continuation of the Historia D. Johann Faustus, printed in 1593, and relates the story of Faustus's famulus, or helper; after his master's horrible death by the hand of Mephistopheles, the famulus travels, and with the Devil's help tours even America (Nicaragua), before suffering the same destiny as Faustus. Georg Wickram's Ritter Galmy (1539) tells of a young man honorably pursuing the love of a lady who eventually marries him after her husband's death. Gabriotto und Reinhart (1551), likewise by Wickram, describes the love of two couples who are friends with each other but cannot realise their dreams of marriage and hence suffer premature deaths.

Sixteenth-century German readers also saw the appearance of a large number of collections of jest narratives, such as Claus Narr, Till Eulenspiegel, or Schiltwach, but these are not examined in the present discussion since they were mostly anthologies of entertaining and didactic tales only loosely held together by a biographical thread. Instead, the focus will rest on some of the most popular and influential manuscript prose novels from the fifteenth century that were subsequently turned into printed books. Some of the manuscript editions gained notoriety after they appeared in print, whereas others were created well after 1450 and reached their audiences from the start as printed books. ${ }^{10}$

A good number of prose novels were translations from the French. Key examples are the anonymous Fierrabras (1533, based on the Roman de Fierabras le Géant of 1478), and the anonymous Haimonskinder (1493, a close rendering of Les quatre fils Aymon, 1493 and 1495); the four novels by Elisabeth von Nassau-Saarbrücken (Herpin, Loher und Maller, Huge Scheppel, and Königin Sibille-written ca. 1437, the first three all printed after 1500); Veit

\footnotetext{
${ }^{10}$ Albrecht Classen, Deutsche Schwankliteratur des 16. Jahrhunderts: Studien zu Martin Montanus, Hans Wilhelm Kirchhof und Michael Lindener (Trier: Wissenschaftlicher Verlag Trier, 2009).
} 
Warbeck's Magelona (of 1527, first printed in 1535; based on the fifteenth-century L'Ystoire du vaillant chevalier Pierre filz du conte de provence et de la belle Maguelonne); Thüring von Ringoltingen's Melusine (1456, first printed in 1474; based on Couldrette's Roman de Mélusine from 1401-05; this, in turn, was translated also into English and Flemish); Wilhelm Salzmann's Kaiser Octavian (first printed in 1535; based on L'histoire de Florent et Lyon, enfants de l'empereur de Rome from 1500 but reprinted in 1526 and 1532); Wilhelm Ziely's Olwier und Artus (first printed in 1521; based on Olivier de Castille et Artus d'Algarbe, 1482) and his Valentin und Orsus (first printed in 1521; based on L'Histoire des deux nobles et vaillants chevaliers Valentin et Orson, 1489); Eleonore of Austria's Pontus und Sidonia (ca. 1460, first printed in 1483); and Marquart von Stein's Der Ritter vom Turm (first printed in 1493; based on Le livre du chevalier de La Tour-Landry pour l'enseignement de ses filles of 1371-1372). ${ }^{11}$ In broad terms, these prose novels explore political, amatory, social, ethical, and chivalric issues of particular interest to an aristocratic audience. The evidence for their wider appeal during the following centuries indicates, however, that subsequent urban and court readers happily accepted them as relevant, interesting, and hence valued reading material for themselves. Although the aristocracy held onto its power after the fifteenth century, the urban class rose strongly and gained much control of newly acquired wealth.

Other novels or novel-like texts were translated from Latin into German, such as Johann Hartlieb’s Historia Alexandri Magni (1454, first printed in 1473); Heinrich Steinhöwel's Historia Apollonii Regis Tyri (1461, first printed in 1471) and his Historia Griseldis (ca. 1461, first printed in 1471); the anonymous Camillus und Emilia (printed first in 1580); Niclas von 
Wyle's Euriolus und Lecretia (1462, first printed in 1478) and his Guiscard und Sigismunde (1494, first printed ca. 1476); Johannes Zschorn's Theagenes und Chariklea (first printed in 1559), and Hans Mair's Geschichte des Trojanischen Krieges (1391, first printed ca. 1407). The two themes that predominate in works of this category are historical events from ancient timesAlexander the Great and the Trojan War-and conflicts in love and marriage. Apparently tragic tales of contemporary life were not to the liking of late medieval and early modern German audiences.

Other popular products on the German early modern book market were didactic tales, such as the Buch der Beispiele der alten Weisen, Salomon und Markolf, and Die sieben weisen Meister. Furthermore, we know of ten major texts that were early modern translations from Middle High German, such as Herzog Ernst, Hürnen Seyfrid, Sigenot der Jüngere, Tristrant und Isalde, Wigalois, Herzog Wilhelm von Orlens, and Wilhelm von Österreich. ${ }^{12}$ These works narrate heroic adventures, travel experiences, love stories, and dynastic wars.

Several conclusions can be drawn from this set of data. First, the medieval tradition continued to be alive and well far into the fifteenth and sixteenth centuries, irrespective of their new format (from verse romance to prose novel) and changed medium (from manuscript to print in the incunabulum, and then in the early modern printed book). The language transitioned from Middle High German to Early Modern German, but the interest in the idealisation of courtly love endured in these prose novels. The same applies to chivalric values, although the printed versions shift the narrative emphasis from one on the protagonist fighting for himself to a story with nationalistic undertones, in which the hero is also defending his country. Second, Thüring von Ringoltingen was given an original work in French and asked to render it into German; the

\footnotetext{
${ }^{12}$ I have drawn most of this information from Gotzkowsky, 'Volksbücher', I.
} 
women translators (Elisabeth von Nassau-Saarbrücken and Eleonore of Austria) brought the original sources with them when they were married to German princes. ${ }^{13}$ In other words, normally we can easily trace the origin of particular translated prose novels, and identify specific reasons why they were rendered into German — as well as the anticipated audience for the translation. Third, the interest in medieval heroic epics and courtly romances continued to be strong throughout the fifteenth and sixteenth centuries, and by then these narratives seem to have appealed to an ever-growing urban readership. Last, the book market for entertaining and popular texts was not limited to one literary genre. Instead, we encounter a strong interest by the reading public in heroic epics, courtly romances, didactic tales, and jest narratives. This means that the audiences were probably mixed, and interested in reading a variety of books that were becoming increasingly available in print. Since book printers and sellers were keen to reach out to diverse social groups — old and young, female and male, secular and clerical, learned and unlearned - as potential customers, they sought to ensure that they had a variety of texts on their tables during the book fairs or in their shops.

\section{Translators' Remarks and the Reception of German Prose Novels}

For the purposes of the present chapter, the many different reasons that motivated the production of literary translations can be usefully narrowed down to a general interest in making the original story or text known to new audiences; the individual translator's enjoyment of translating from one language to another; the translator's hope of attracting a potential audience to her or his own

\footnotetext{
${ }^{13}$ Susan Groag Bell, 'Medieval Women Book Owners: Arbiters of Lay Piety and Ambassadors of Culture', Signs, 7 (1982), pp. 742-768.
} 
original culture; financial reasons - that is, the need to make a living — and the perceived need for access to the information contained in a foreign-language book. ${ }^{14}$

A sample of translated prose novels offers material for better understanding how the various translators explained their task to their readers, and how they evaluated their source material. Further, it makes possible a sketch of the German history of reception into the seventeenth century as an indicator of the market appeal of particular books over time. In the prologue to his novel Melusine of 1456, Thüring von Ringoltingen (1415-1483) emphasises, for instance, that, according to Aristotle's Metaphysics, every person is interested to learn as much about the world as possible, which implies both natural and unnatural aspects, material and metaphysical. Consequently, when he came across the "selcame vnd auch gar wunderliche fremde Hystoryen" ("strange and mysteriously puzzling history", p. 13) of Melusine and her life, originally composed in French, he decided to render it into German ("ist der syn der hystoryen zuo teütsch also", p. 13) in honour of and maybe also on behalf of his lord, the Margrave Rudolf of Hochberg, Count of Neuchâtel, Switzerland. However, von Ringoltingen immediately adds the proviso that he might be limited in his abilities ("nach meinem besten vermügen", p. 13) —a typical formula for expressing humility. He then explains that even if he might not have translated the original text perfectly into German, he still strove to render the account to the best of his abilities: "so best vnd ich kund begriffen" ("as well as I could grasp it", p. 14).

Rudolf of Hochberg was intimately connected with the Burgundian court of Duke Philip the Good of Burgundy. He spoke fluent French, as von Ringoltingen points out in his epilogue, where the translator resorts to another typical humility formula, here with reference to his own

\footnotetext{
${ }^{14}$ For a variety of critical reflections on translations, see the contributions to María del Mar Rivas Carmona and María del Carmen Balbuena Torezano (eds.), Cultural Aspects of Translation (Tübingen: Narr, 2013).
} 
linguistic skills that cannot match those of his patron (p. 175). The Count of Neuchâtel would not have needed von Ringoltingen's help in comprehending the French original. However, von Ringoltingen referred to him as his sponsor and patron, hoping thus to enhance the appeal of his novel for the wider audience in Bern, and elsewhere, which was interested to forge cultural bonds with the French world, and imitate the courtly culture there-as represented by the Melusine material. $^{15}$

Even so, reading the novel Melusine was not simply regarded as an official duty for demonstrating the reader's level of education and learning. On the contrary, this was a most fascinating, mysterious literary account of the hybrid creature Melusine - fabled to have been half a snake-figure and half an ordinary woman, and the founding person or mother of the entire Lusignan dynasty, the members of which assumed, as von Ringoltingen asserts (p. 12), many different rulerships all over Europe. Quoting Psalm 68:36, "Mirabilis deus in operibus suis" (“God is miraculous in His works", p. 12), von Ringoltingen underscores that Melusine's magical abilities highlight God's grace on earth. In other words, his personal fascination with this literary material is clearly expressed, as is his hope to appeal to a large audience with his translation: "Wann auch solich schoen vnd fremd hystory vast lieplich vnd lustlich zuo lesen vnd zuo hoeren seind vnd den leutten zuo sagen zu preysen seind" (“After all, such wonderful and strange stories are delightful and entertaining to read and to listen to, and it is praiseworthy to relate them to people", p. 12). ${ }^{16}$ Von Ringoltingen imagines that his novel will be read silently by

\footnotetext{
${ }^{15}$ See the commentary in Romane des 15. und 16. Jahrhunderts, pp. 1020-1022.

${ }^{16}$ The spelling and style of this and the following quotations have been standardised.
} 
individuals, and also read aloud to an audience that might not yet be quite literate; at any rate, he seems to have assumed a mixed situation typical of late medieval urban culture. ${ }^{17}$

For von Ringoltingen, there is no higher art in life than "kunst vnd abentewr . . lieb zuo haben" ("[that of] enjoy[ing] art and adventure", p. 12), but he also discriminates between his own novel and the vast corpus of medieval romances, claiming that Melusine outshines even such masterpieces as Gottfried von Straßburg's Tristan, or Wolfram von Eschenbach's Parzival (p. 176). As such, it is possible to conclude that the epics and romances from the high Middle Ages were still highly esteemed and known among many circles of literati. Yet despite the ancient motif of Melusine as a hybrid creature — which had been written about in the twelfth century by Walter Map and Gervasius of Tilbury —-Thüring claims that his novel represents a new and important innovation.

Indeed, the translator makes a valiant attempt to connect his literary account with actual historical conditions, referring to various castles and other buildings mentioned in his text that still existed at his time; mentioning also various members of the French nobility who were somehow related to Melusine. Thus in this work von Ringoltingen makes a case for the historical validity of his story — further justifying his translation. In this regard he shared the same interest in this literary material demonstrated by his French predecessors Jean d'Arras and Couldrette,

\footnotetext{
${ }^{17}$ D. H. Green, Medieval Listening and Reading: The Primary Reception of German Literature 800-1300 (Cambridge UK: Cambridge University Press, 1994); for the situation in the late Middle Ages see Wieland Schmidt, 'Vom Lesen und Schreiben im späten Mittelalter', in Dietrich Schmidtke and Helga Schüppert (eds.), Festschrift für Ingeborg Schröbler zum 65. Geburtstag (Tübingen: Max Niemeyer, 1973), pp. 309-327.
} 
who served an international audience of high-ranking nobility with their account of the mysterious founding mother of a vastly extended dynasty originating from Poitiers. ${ }^{18}$

At the end of the narrative, the printer of one of the earliest editions, Johann Bämler in Augsburg, adds a colophon. Not uncommonly for printed works in this genre during the fifteenth century, the printer does not remark on the text itself; nor does he indicate what he might have hoped to achieve with this publication. The same can be observed in the case of the Basel print edition (Richel), from $c a .1473 .{ }^{19}$ Yet we must particularly consider the actual situation separating the original text from its early printed versions. Von Ringoltingen completed his loose adaptation of the French text by Couldrette in 1456, and this version has survived in sixteen manuscripts. The earliest dates from 1467 and is today in the collection of the Stiftsbibliothek Klosterneuburg (no. 747), near Vienna. (None of the manuscripts can be identified as a holograph, which is, of course, hardly unusual for medieval manuscripts.) In all, Bämler picked up a manuscript of von Ringoltingen's popular story in 1474 - that is, twenty-eight years after von Ringoltingen had finished his work. ${ }^{20}$ Von Ringoltingen passed away on 8 March 1483; by that time the family had gained full recognition of its new noble status. It is unlikely that Bämler had asked von Ringoltingen, von Ringoltingen's son, or any other family relative for permission

\footnotetext{
${ }^{18}$ Backes, Fremde Historien, pp. 166-175 emphasises, however, that the range of audiences in the German-speaking lands was different compared to France since only lower-ranked nobility showed explicit interest in this novel, apart from the wider non-aristocratic audiences in cities.

${ }^{19}$ Thüring von Ringoltingen, Melusine (1456). Nach dem Erstdruck Basel: Richel um 1473/74, ed. André Schnyder and Ursula Rautenberg (2 vols., Wiesbaden: Reichert, 2006).

${ }^{20}$ Heidrun Stein-Kecks (ed.), Die schöne Melusina: Ein Feenroman des 15. Jahrhunderts in der deutschen Übertragung des Thüring von Ringoltingen: Die Bilder im Erstdruck Basel 1473/74 nach dem Exemplar der
} Universitäts- und Landesbibliothek Darmstatdt (Darmstadt: Wissenschaftliche Buchgesellschaft, 2012), p. 11. 
to print this novel. Most printers tended to print whatever reading materials they could most easily source. The marketing risk was theirs anyway, so they tended to be preoccupied by the question of who would be willing to pay for the printing (and not by concerns about the authorial origins of a specific text).

Bernhard Richel in Basel competed with Bämler, and produced a parallel print run of approximately two hundred copies. Printed in folio format, with a wide margin, this version included a rich set of illustrations, which must have made it a very costly edition, affordable only for the wealthy. ${ }^{21}$ The most likely date for Richel's version is the turn of 1473 to 1474 , based on the paper and the water marks, apart from some other criteria, such as the style of the illustrations.

Altogether, von Ringoltingen's Melusine was printed thirty times until the end of the sixteenth century, the last time by the famous Frankfurt printer Sigmund Feyerabend in $1587 .^{22}$ The seventeenth century witnessed further prints of the novel; that is, twice in 1700 (n.p.), once in Hamburg in 1649, and once in Nuremberg in $1672 .{ }^{23}$ I have also identified editions from 1720 (n.p.), 1739 (n.p.), 1750 (n.p.), 1772 (Leipzig), and from 1780 (Frankfurt). From there the history of the novel's reception continues when the Romantics discovered von Ringoltingen's novel, printed in Cologne in 1800; there followed a long series of modern Melusine translations,

\footnotetext{
${ }^{21}$ Die schöne Melusina, p. 27.

${ }^{22}$ Gotzkowsky, 'Volksbücher', I, pp. 105-125.

${ }^{23}$ See the online catalogue $V D 17$ at http://gso.gbv.de/DB=1.28/SET=1/TTL=11/NXT?FRST=1 (accessed 2 January 2017). The VD17 is the Verzeichnis der deutschen Drucke, an almost complete collection of all German printed material produced in the seventeenth century. The VD16 is the complementary catalogue for the sixteenth century.
} 
reprints, redactions, adaptations, settings to music, as well as paintings and sculptures. ${ }^{24}$ In 2017 the figure of Melusine can be found depicted in the logo of the global Starbucks coffee houses. Countess Elisabeth von Nassau-Saarbrücken (ca. 1395-1456) was a French princess who married the Count Philip I of Nassau-Weilburg-Saarbrücken (1368-1429). After his death in 1429 and until 1438 she served as regent for her infant son Philip II (1418-1492), of the NassauSaarbrücken territory (today western Germany). ${ }^{25}$ In 1437 she published the four novels already mentioned—Herpin, Loher und Maller, Huge Scheppel, and Königin Sibille—all in manuscript format; they were printed shortly before or well after her death. Herpin, for instance, was copied three times in fifteenth-century manuscripts (in 1455, 1475, and 1487), but print versions appeared in Straßburg in 1514; in Frankfurt in 1567, 1579, and 1587; in Augsburg in 1580, and in Leipzig in $1590 .{ }^{26}$ Loher und Maller has survived in five manuscripts and three editions printed in the sixteenth century: Straßburg in 1514; Frankfurt $c a$. 1558, and again in 1567; finally

${ }^{24}$ The edition of 1800 has the fanciful title Historische Wunder-Beschreibung von der sogenannten schönen Melusina, Königs Helmas in Albanien Tochter: Welche eine Sirene und Meer-Wunder gewesen, und ihrer Hervorkunft aus dem in Frankreich gelegenen Berg Adelon, Auch was sich allda sehr seltsam und merkwürdiges mit ihr zugetragen. For a survey of the relevant research on this novel, see Albrecht Classen, The German Volksbuch, pp. 141-162.

${ }^{25}$ Bernhard Burchert, Die Anfänge des Prosaromans in Deutschland: Die Prosaerzählungen Elisabeths von NassauSaarbrücken (Frankfurt, Bern, and New York: Peter Lang, 1987); Ute von Bloh, Ausgerenkte Ordnung: Vier Prosaepen aus dem Umkreis der Gräfin Elisabeth von Nassau-Saarbrücken: 'Herzog Herpin', 'Lother und Maller', 'Hugo Scheppel', 'Königin Sibille' (Tübingen: Max Niemeyer, 2002); see also the contributions to ed. Wolfgang Haubrichs, Hans-Walter Herrmann and Gerhard Sauder (eds.), Zwischen Deutschland und Frankreich: Elisabeth von Lothringen, Gräfin von Nassau-Saarbrücken (St. Ingbert: Röhrig Universitätsverlag, 2002).

${ }^{26}$ Gotzkowsky, 'Volksbücher', I, pp. 79-83. 
also in Leipzig in 1613. Only von Nassau-Saarbrücken's Königin Sibille never attracted the interest of printers - this prose novel has been preserved in just one manuscript. ${ }^{27}$

Von Nassau-Saarbrücken gives a detailed account of her translations, as in the case of Loher und Maller, where she declares first that the epic poem had originally been written in Latin; it was then translated into French, and she then rendered it into German. ${ }^{28}$ The text has survived, after she had created it in 1437, in manuscripts from 1456 (Hamburg), 1463 (Heidelberg), 1482 (Křivoklát/Pürglitz), 1486 (Cologne), and 1493 (Vienna). ${ }^{29}$ The late date of the first printed edition in 1514 makes impossible an exploration of the connection between the translator and the printer. It is certain, however, that the latter chose this text so as to gain good profits from its publication. Given the numerous reprints indicated above, he was certainly not disappointed in that regard.

\footnotetext{
${ }^{27}$ For more background, see the contributions to Wolfgang Haubrichs and Patricia Oster (eds.), Zwischen Herrschaft und Kunst: Fürstliche und adlige Frauen im Zeitalter Elisabeths von Nassau-Saarbrücken (14.-16. Jh.)

(Saarbrücken: SDV Saarländische Druckerei und Verlag, 2013). For a specialised study, see Albrecht Classen, 'Schrecken und Grauen, Mord und Totschlag: Das Entsetzen literarisch eingefangen. Spiegelung des Schmerzes und brutaler Misshandlungen in Elisabeths von Nassau-Saarbrücken Loher und Maller (1437)', Neuphilologische Mitteilungen, 116 (2015), pp. 133-147.

${ }^{28}$ Ute von Bloh and Silke Wirnst (eds.), Loher und Maller: Kritische Edition eines spätmittelalterlichen Prosaepos (Berlin: Erich Schmidt, 2013), p. 1. I disagree with von Bloh regarding her scepticism concerning Elisabeth's authorship because there are no serious reasons to raise doubts, while her French origin would not have mattered in this case since she must have received very solid language training in preparation for her marriage and during her life in Saarbrücken.

${ }^{29}$ Loher und Maller, p. xxvi.
} 
As narrated in the epilogue, von Nassau-Saarbrücken's mother Margarete, wife of Duke Frederick of Lorraine, had rendered the Latin into a French version of the story in 1405 . Elisabeth undertook to translate it into German long after she had moved to Germany: "Vnd ist diß buoch ouch vorbaß von welsch zu dütsch gemacht durch die wolgeborne frowe Elizabeth von Lotringen, freyffyne wytwe zu Nassauwe vnd Sarbrucken, ... die es durch sich selbs also bedütschet hat, als es hie vor an beschriben stat" ("And this book was best translated from French into German by the highly born Lady Elizabeth of Lorraine, Noble Widow of Nassau and Saarbrücken, ... who rendered it into German herself, as it is written here", p. 416). She enlisted the collaboration of her own staff helping her in creating this work, as the reference to the scribe suggests: "bittent ouch vor den schriber" ("pray also for the scribe", p. 416), but she does not mention his name. It is not relevant to consider whether the scribe might have been her ghostwriter, in part because noblewomen throughout the Middle Ages were the leading figures in the creation of courtly literature, either as poets (such as Marie de France), or as patrons. Moreover, von Nassau-Saarbrücken's linguistic skills, and her talents as a writer, are well accounted for. ${ }^{30}$

Other novels by von Nassau-Saarbrücken tend to offer no comments by the authortranslator; nor do the sixteenth-century printed versions include interpolations made by the the printer. Although von Nassau-Saarbrücken's version of Herpin, for example, includes a prologue

\footnotetext{
${ }^{30}$ Albrecht Classen, 'Women in $15^{\text {th }}$-Century Literature: Protagonists (Melusine), Poets (Elisabeth von NassauSaarbrücken), and Patrons (Mechthild von Österreich)', in James Hardin and Jörg Jungmayr (eds.), 'Der Buchstab tödt - der Geist macht lebendig'. Festschrift zum 60. Geburtstag von Hans-Gert Roloff (2 vols., Bern: Peter Lang, 1992), I, pp. 431-458; see also the contributions to June Hall McCash (ed.), The Cultural Patronage of Medieval Women (Athens GA: University of Georgia Press, 1996).
} 
and an epilogue, both sections contain no relevant remarks outside of the literary framework. ${ }^{31}$ The fifteenth-century manuscripts are all elaborately illustrated, and appear to have been destined for the higher ranked nobility who had the means to invest in such works. The print tradition is marked by the astounding quantity of copies produced and sold. The Frankfurt bookseller Michel Harder noted that he sold seventy-seven copies of von Nassau-Saarbrücken's Herpin during the Frankfurt book fair in 1567, although he makes no reference to her role as author-translator. In fact, with reference to sixteenth-century German literature "of entertainment", Herpin appears to have enjoyed one of the highest levels of popularity. ${ }^{32}$

Unfortunately, the third novel by von Nassau-Saarbrücken, Hug Schappler, as exemplified in the print version from 1500, provides no information about the author-translator; however, here the printer identifies himself briefly by name, Hans Grueniger (p. 539). The 1537 print contains a more detailed colophon, relying on a formulaic statement which deserves to be quoted entirely: "Getruckt in der loeblichen freyen statt Strasz | burg / durch Bartholomeum Grueniger/ vnd vollendet an | dem zwoelfften tag des Mertzens / in dem jar als man | zalt nach Christi vnsers Heylands geburt. | MDXXXVII" ("printed in the praiseworthy free city of Straßburg by Bartholomeus Grueniger and completed on the twelfth of March in the year 1537

\footnotetext{
${ }^{31}$ Bernd Bastert (ed.), Herzog Herpin: Kritische Edition eines spätmittelalterlichen Prosepos (Berlin: Erich Schmidt, 2014). As in the case of Loher und Maller, I disagree with Bastert's position that this novel cannot be attributed to Elisabeth von Nassau-Saarbrücken.

${ }^{32}$ Hans-Joachim Koppitz, 'Zur Verbreitung unterhaltsamer und belehrender deutscher Literatur durch den Buchhandel in der zweiten Hälfte des 16. Jahrhunderts', Jahrbuch für Internationale Germanistik, 7 (1975), pp. 2035, at p. 31, lists 1719 sold copies of Herpin during the sixteenth century. With 1400 copies sold, Loher und Maller ranks as number eleven, and Hug Scheppel with 800 copies as number 24 .
} 
after the birth of our Lord Christ"). ${ }^{33}$ Notwithstanding such conventional syntax, the inscription well conveys pride and self-consciousness on the part of the printer, who certainly understood that this was an attractive book with favourable prospects on the book market. However, as already noted above (and not uncommonly for the era), German author-translator is not mentioned or cited.

By contrast, acknowledgement of the author-translator or the source is comparatively well documented in the case of the prose romance Pontus und Sidonia as translated by Eleonore of Austria (1433-1480). This novel was translated three times from French into German by various individuals, but only Eleonore of Austria's version was also printed. The daughter of King Jacob I of Scotland, she married Duke Sigmund of Tyrol and Vorarlberg in 1448. Having been educated at the royal court of Paris, Eleonore of Austria's had gained a good knowledge of contemporary literature, and demonstrated her interest in such matters through this translation, which appeared in manuscript sometime around $1460 .{ }^{34}$ Her source was Ponthus et la belle Sidoyne, composed, it seems, by Geoffrey de la Tour Landry (ca. 1330-ca. 1402) at the end of the fourteenth century. That in turn was based in part on the Anglo-Norman romance Horn et Rimenhild (ca. 1180) or the Middle English King Horn (end of the thirteenth century). In parallel with Eleonore of Austria's translation, two anonymous male translators each produced a German version, but these seem to have met with limited success: one survives in only five manuscripts (the so-called version B), and the other in just one manuscript (the so-called version C).

\footnotetext{
${ }^{33}$ Here I rely on the text edition contained in Romane des 15. und 16. Jahrhunderts, pp. 343-381. The colophon is from Gotzkowski, 'Volksbücher', I, p. 86.

${ }^{34}$ Maria Müller, 'Pontus und Sidonia', in Achim Achnitz (ed.), Deutsches Literatur-Lexikon. Das Mittelalter (8 vols., Berlin and Boston: Walter de Gruyter, 2013), V, pp. 1575-1598.
} 
Eleonore of Austria's Pontus und Sidonia was printed for the commercial book market posthumously by her husband Duke Sigmund. We know of one manuscript (Gotha FB), four incunabula from Augsburg (dating to 1483, 1485, 1491, and 1498), and of twelve early modern prints from the sixteenth century. ${ }^{35}$ Older scholarship tried to argue that Eleonore of Austria could not have created this novel herself, dismissing her as a female author of foreign descent probably lacking in the necessary linguistic skills. Hence this interpretive tradition attributed the work to her husband, who allegedly sought financial gain by naming his deceased wife in the prologue-but this is no longer a valid position. ${ }^{36}$

Unusually, in the fifteenth-century editions printed in Augsburg the prologue provides information about the translator and her work. First, the text itself is praised as a "schöne Hystori" ("delightful story", p. 43), which offers a wealth of instructions and teachings for young people. Next, the author-translator introduces herself, and confirms that she was responsible for this work, giving herself praise: "löblich von frantzosischer zungen in teütsch getranßferiert vnd gemacht hat" ("who has translated this in a praiseworthy fashion from French into German", p. 43). She also refers to her husband, the dedicatee of the novel: "czuo lieb vnd zuo geuallen" (“out of love and to please him", p. 43). No details follow concerning the source, the process of

\footnotetext{
${ }^{35}$ Reinhard Hahn (ed.), Eleonore von Österreich: Pontus und Sidonia (Berlin: Erich Schmidt, 1997).

${ }^{36}$ Reinhard Hahn, 'Von frantzosischer zungen in teütsch'. Das literarische Leben am Innsbrucker Hof des späteren 15. Jahrhunderts und der Prosaroman 'Pontus und Sidonia (A)' (Frankfurt and Bern: Peter Lang, 1990). In his 1997 edition, Hahn quietly dismisses this notion himself. The reason for such a speculation is that the manuscript does not contain Eleonore's name, whereas the print version does. One simple explanation for that would be that the print mode invited much more than the manuscript version to be specific about the author and printer.
} 
translation, or any related linguistic difficulties and challenges. Likewise, the printer, Hans Schönsperger from Augsburg, simply added his colophon without further comments.

Veit Warbeck’s Magelona from 1527 can serve here as a final example of a translated prose novel. While it dates from a considerably later time, the text conforms mostly to the same genre concepts identifiable in the preceding examples. Warbeck (1490-1534) was a learned scholar, diplomat, and poet who worked at the court of the Prince Elector Frederick the Wise in Weimar; he dedicated his translation to the Crown Prince Frederick of Saxony on the occasion of Frederick's wedding with Sybille of Jülich-Cleve (June 1527). We know of the French original, L'Ystoire du vaillant chevalier Pierre filz du conte de provence et de la belle Maguelonne (midfifteenth century), which Warbeck shortened dramatically to produce Magelona. ${ }^{37}$ As a reflection of the changing cultural conditions, this love story is strongly characterised by the author-translator's efforts to introduce Protestant ethics and values. The novel obviously held much appeal, as demonstrated by the twenty-one printed editions documented from 1535 onwards (the last appeared in 1593). ${ }^{38}$ In the seventeenth century the novel continued to be appreciated by the public, and it was reprinted in 1601, 1660, and 1678 .

Magelona opens with dedication written by the humanist and theologian Georgius Spalatinus. In the prologue that follows, Warbeck identifies the French source of his novel, and gives its date as 1453 . He seems only concerned to provide a brief summary of the story before the tale itself begins. The different colophons include no remarks about the translation process,

\footnotetext{
${ }^{37}$ Die Schön Magelona: Ein fast lustige vnd kurtzweylige Histori vonn der schönen Magelona (Hildesheim and New York: Georg Olms, 1975); see also the edition in Romane des 15. und 16. Jahrhunderts, pp. 587-677.

${ }^{38}$ Gotzkowsky, 'Volksbücher', I, pp. 93-104.
} 
and no additional information beyond the name of printer in each case- - such as Heinrich Steyner (Augsburg, 1535).

The last example makes possible several concluding, reflective comments on the phenomenon of the 'new' genre of prose novels in German. The invention of the printing press certainly supported the vast dissemination of the individual works, but it was not fundamental to the creation of those novels in the first place. Translators, printers, and their intended readers and listeners were evidently interested in the medieval narratives and values, but also appreciated a variety of other texts, often translated from French, Latin, and Italian sources. Some of the translators discussed herein set down in the first person remarks about their efforts to create their versions, but most novels prove silent on the matter. The names of printers appear regularly in the various colophons, but the printers themselves did not tend to add observations about the novels themselves. The printers were all situated in major German cities famous for their trade and cultural refinement, yet the novels regularly reflect backwards, and take the world of the medieval aristocracy into view. We could also examine in greater detail those prose novels based on medieval heroic epics, but the result would be the same, with even fewer comments by the anonymous authors or translators.

Altogether, the late fifteenth century witnessed the strong rise of a new genre of entertaining and didactic literature which robustly sustained the new book markets, and allowed reading audiences to enjoy accounts of courtly lovers who overcome considerable challenges because of their superior character strengths and values. The printers of such prose novels could 
only profit from such a nostalgic taste in literature, which was found even among the urban citizens who apparently deeply desired to imitate the traditional courtly culture — at least in imagination. Little wonder that print workshops became ubiquitous, particularly in southern Germany where the old and mighty imperial cities were located. The sixteenth and seventeenth centuries observed a significant move to the centre and north of Germany, but the prose novel as a literary genre maintained its far-reaching appeal. 


\section{CHAPTER 7}

\section{Reframing Idolatry in Zapotec: Dominican Translations of the Christian Doctrine in Sixteenth-Century Oaxaca}

\section{David Tavárez}

After the Spanish military defeat of the Mexica (Aztec) empire in 1521, friars representing missionary orders who arrived between 1522 and 1535-Franciscans, Dominicans, and Augustinians - began the ambitious enterprise of providing instruction on fundamental Christian beliefs to millions of indigenous peoples in the lands that would be known as New Spain. In order to propagate Christianity through sermons and catechetical education, they created dictionaries and grammars, and translated a basic Christian lexicon into a variety of indigenous languages; first into Nahuatl, the language of the Mexica empire, and then into Phurépecha, Zapotec, Mixtec, Maya variants, Otomi, Huastec, and other Mesoamerican languages. Missionary authors worked with indigenous scholars and assistants that remained, for the most part, anonymous. ${ }^{1}$ These lexicographic and educational projects led to the emergence of a devotional literature which circulated either through manuscripts among missionaries and some native Christians, or via imprints destined for ecclesiastic use, and also for literate indigenous audiences. ${ }^{2}$

\footnotetext{
${ }^{1}$ A unique discussion of the role of Nahua scholars as co-authors of doctrinal and lexicographic works appears in Juan Bautista Viseo, Sermonario en lengua mexicana (Mexico City: Diego López Daualos, 1606), Prologue.

${ }^{2}$ See, for instance, Louise Burkhart, The Slippery Earth: Nahua-Christian Moral Dialogue in Sixteenth-Century Mexico (Tucson: University of Arizona Press, 1989); Mark Z. Christensen, Nahua and Maya Catholicisms: Texts and Religion in Colonial Central Mexico and Yucatan (Stanford, CA: Stanford University Press, 2013); David Tavárez (ed.), Words and Worlds Turned Around: Indigenous Christianities in Colonial Latin America (Boulder, University of Colorado Press, 2017).
} 
During the second half of the sixteenth century, the Dominican order, which was able to spread beyond Central Mexico and take responsibility for indigenous evangelisation in the diocese of Oaxaca in New Spain, produced catechetical works and devotional songs in Zapotec and Mixtec. In demographic terms, these were two of the most important languages of the region. While there were some overlaps between Dominican approaches and those of the Franciscan order (which controlled many parishes in the neighboring diocese of Mexico), the Dominicans developed an orthodox and highly regimented approach to the editing and translation of Christian doctrinal works.

In the sixteenth century, the Order of Preachers produced three highly influential important imprints in Zapotec: a dictionary, a grammatical description, and a catechetical manual. ${ }^{3}$ Together the first two of these comprised the most authoritative vocabulary and description of Colonial Zapotec (in its Valley variant); they were published in 1578 by Juan de Córdova in separate volumes as Vocabulario en lengua Çapoteca, and Arte en lengua zapoteca. The present chapter, however, focuses on the third work, Pedro de Feria's Doctrina christiana en lengua castellana y çapoteca, which was printed in Mexico City in 1567 by Pedro Ocharte. ${ }^{4}$ Feria's volume eventually became one of the most influential summaries of

\footnotetext{
${ }^{3}$ Unless otherwise indicated, all translations from the Latin, Nahuatl, and Zapotec are by David Tavárez. The search for lexical items and morphemes in Córdova's 1578 dictionary was facilitated by an electronic resource comprising all of the entries in this dictionary: Thomas Smith-Stark, Sergio Bogard, and Ausencia López Cruz, Archivo electrónico del 'Vocabvlario’ en lengva çapoteca de Juan de Córdova (electronic file, 1993; Word Perfect 8, 7.7 MB). See also Thomas Smith-Stark, 'La ortografía del zapoteco en el 'Vocabulario' de fray Juan de Córdova', in María de los Ángeles Romero Frizzi (ed.), Escritura zapoteca. 2,500 años de historia (Mexico City: CIESAS, INAH, Editorial Porrúa, and CONACULTA, 2003), pp. 393-448.

${ }^{4}$ For previous analyses of Feria's Doctrina, see Elisa Luque Alcaide, 'Paternidad de Dios en el catecismo zapoteco de Pedro de Feria’, in José Luis Illanes, Javier Sesé, Tomás Trigo, Juan Francisco Pozo, and José Enériz (eds.), El Dios y Padre de Nuestro Señor Jesucristo (Pamplona: University of Navarra, 2000), pp. 165182; Luis Resines (ed.), Catecismo del Sacromonte y Doctrina Christiana de Fr. Pedro de Feria: Conversión y
} 
the Christian doctrine in the Zapotec language. This chapter illuminates the carefully balanced path that Feria undertook, as author, editor, and chief translator who presided over several anonymous Zapotec assistants, as he produced an orthodox Christian text that would remain a major influence on catechesis in colonial Zapotec in the seventeenth and eighteenth centuries. As part of an overview of Dominican strategies for rendering Christian teachings accessible and engaging for Zapotec speakers, I begin with a survey of Dominican language policies regarding Zapotec catechesis. These policies were distinct from the more adventurous path embraced by the Franciscan order in Central Mexico. The chapter then turns to the emergence of a Christian lexicon based on Feria's strategic vetting of Zapotec political, moral, and cosmological discourse. There follows a detailed analysis of the ways in which Feria chose to render Thomas Aquinas's authoritative opinions on the origins of idolatry. As shown below, Feria's choices were highly creative; he rearranged and adapted the arguments made by Aquinas in the Summa theologica such that they became a compelling narrative for neophytes. Feria did so through recourse to another important Dominican theologian, Antoninus of Florence.

evangelización de moriscos e indios (Madrid: CSIC, 2002). An analysis of the rhetorical devices employed by Feria, Agüero, and other Dominican authors appears in Nancy Farriss, Libana. El discurso ceremonial mesoamericano y el sermón cristiano (Mexico City: Artes de México, Biblioteca Fray Juan de Córdova, Fundación Alfredo Harp Helú, 2014), pp. 45, 89, 115, and 126. Farriss attributes these devices to a direct transfer from the pre-Conquest Zapotec rhetorical tradition. However, she rarely addresses the many examples of colonial Zapotec rhetoric traditions written by Zapotec themselves, which survive in nearly six hundred mundane civil records, and also in collections of traditional songs for the ancestors or Christian entities. For the latter, see David Tavárez, 'The Passion According to the Wooden Drum: The Christian Appropriation of a Zapotec Ritual Genre in New Spain', The Americas 62 (2006), pp. 413-444; and David Tavárez, 'Performing the Zaachila Word: The Dominican Invention of Zapotec Christianity', in Words and Worlds, n.p. 


\section{Dominican Linguistic Policies and the Early Colonial Zapotec Corpus}

The translation work of missionary authors and their indigenous co-authors and assistants was subject to mounting scrutiny as the sixteenth century progressed. After its foundation by the Franciscans in 1536, the Colegio de Santa Cruz, the first school for indigenous elites, thrived as an institution where Nahua scholars were trained in the liberal arts, and which fostered collaboration between Franciscan authors and their students. However, after the First Mexican Church Council (1555), manuscript copies of catechetical works in indigenous languages were subject to closer examination, since not all such works were permitted to circulate among natives, and all new translations were expected to include the author's name, and receive approval from an ecclesiastical expert in the relevant tongue. In 1559, shortly after these measures were proclaimed, the Bishop of Michoacán ordered the confiscation of a group of moral dialogues in Phurépecha and Spanish, texts which were intended for natives and written by the Franciscan Maturino Gilberti. This removal was justified by important divergences between the differences between the Phurépecha and Spanish texts, and by "things impertinent and ill-sounding to our ears". 5 In 1585, the Third Mexican Church Council would further increase the stakes by forbidding, on pain of excommunication, the circulation of catechetical texts in indigenous languages that did not bear a licencia del ordinario (bishop's authorisation) which ratified their translation. ${ }^{6}$ A more resolute turn towards orthodoxy, propelled by the creation of a separate inquisitorial tribunal in New Spain, and the application of recommendations issuing from the Council of Trent, would occur during the administration of the archbishop of Mexico Pedro de Moya y Contreras

\footnotetext{
${ }^{5}$ Mexico City, Archivo General de la Nación, Inquisición, vol. 43, no. 6, fols. $197^{\mathrm{r}}-230^{\mathrm{v}}$.

${ }^{6}$ Francisco Antonio Lorenzana, Concilios Provinciales Primero y Segundo, celebrados en la . . ciudad de México ... en los años de 1555 y 1565 (Mexico City: Imprenta del Superior Gobierno, 1769), p. 14.
} 
$(1573-1591) .^{7}$

The Dominicans of New Spain maintained a disciplined approach to catechesis that was a particularly good fit with the focus on catechetical instruction and orthodox use of scripture mandated by the Council of Trent. The less orthodox Franciscans established a school for indigenous elites; printed lives of saints and other works in the tradition of "contempt for the world"; prepared Nahuatl-language translations, and commentaries on books from the Old and New Testaments. ${ }^{8}$ Two episodes epitomise the distinctions between Dominicans and Franciscans in terms of translation policies. In 1577, in their answers to a questionnaire drafted by the Mexican Inquisition, the Dominicans Juan de la Cruz and Domingo de la Anunciación contended that translations of scripture into native languages (a reference to Nahuatl translations of Ecclesiastes and Solomon by the Franciscans), were not needed for catechesis. However, the Franciscans Alonso de Molina and Bernardino de Sahagún contended that this proscription harmed native evangelisation. ${ }^{9}$ Moreover, in 1611 , a decade after the Franciscan Juan Bautista Viseo proposed a revised translation for the phrase "Holy Trinity" into Nahuatl, twelve prominent Dominicans responded by coining a neologism, "divine human being" (teotlacatl). ${ }^{10}$

\footnotetext{
${ }^{7}$ For a discussion of these factors, see Stafford Poole, Pedro Moya de Contreras: Catholic Reform and Royal Power in New Spain, 1571-1591 (Berkeley: University of California Press, 1987), and Martin Nesvig, Ideology and Inquisition: The World of the Censors in Early Mexico (New Haven, CT: Yale University Press, 2009).

${ }^{8}$ See David Tavárez, 'Nahua Intellectuals, Franciscan Scholars, and the devotio moderna in Colonial Mexico', The Americas 70 (2013), pp. 203-235.

${ }^{9}$ A ban of all vernacular translations of scripture was in place after the promulgation of the 1559 inquisitorial Index. See Nesvig, Ideology and Inquisition, pp. 153-157.

${ }^{10}$ Juan Bautista Viseo, Advertencias para los confessores de los naturales (Tlatilulco: Melchior Ocharte, 1600), fols. 53ํ-54 ${ }^{\mathrm{r}}$; Martín de León, Camino del Cielo en Lengua Mexicana (Mexico: Diego López Dávalos, 1611), Preface.
} 
Along with an interest in controlling printed and manuscript translations of devotional works into indigenous languages, the Third Mexican Church Council and other conclaves did emphasise the importance of training ministers to use native languages in catechesis. ${ }^{11}$ In fact, during the Third Council, Feria noted that ministers who did not speak his parishioners' language and only visited them to collect yearly contributions could neither instruct them nor end their idolatry. ${ }^{12}$ The practical context for Feria's point included limitations in the number of Dominicans in Oaxaca who were fluent in indigenous languages, and the limited availability of catechetical aids in these tongues. In the sixteenth century, the number of Dominican ministers with indigenous linguistic competence was small. In 1571, for thirtythree Oaxacan parishes, only thirty-two ministers and seven ecclesiastics at the cathedral knew indigenous languages; while most were familiar with Nahuatl, only fourteen knew some Zapotec. ${ }^{13}$

Hence the Dominicans of Oaxaca were thoroughly committed to the use of Zapotec for evangelisation, and were proud of their command of a language so unlike Hebrew, Latin, and European vernaculars. In the preamble to his 1578 Vocabulario, Juan de Córdova depicted New World philologies as a monumental project based on experience, which

\footnotetext{
${ }^{11}$ Sonia Corcuera de Mancera, 'Cuestión de palabras: el indio en el III Concilio Provincial Mexicano', in Francisco Cervantes and María del Pilar Martínez (eds.), Los concilios provinciales en Nueva España (Mexico City: UNAM, 2005), pp. 171-181. For catechesis and the Council of Trent, see William B. Taylor, Magistrates of the Sacred (Stanford, CA: Stanford University Press, 1996), p. 152.

${ }^{12}$ Alberto Carrillo Cázares (ed.), Manuscritos del concilio tercero provincial mexicano (1585) (5 vols., Guadalajara: Colegio de Michoacán-Universidad Pontifica de México, 2011), V, 1, pp. 291-292. See also Rodolfo Aguirre, 'El tercer concilio mexicano frente al sustento del clero parroquial', Estudios de Historia Novohispana 51 (2014), pp. 9-44.

${ }^{13}$ Luis García Pimentel (ed.), Relación de los obispados de Tlaxcala, Michoacán, Oaxaca, y otros lugares en el siglo XVI (Mexico City: Luis García Pimentel, 1904), pp. 95-97.
} 
compared favorably to similar projects in Europe. Córdova noted that God gave men "a tongue, so he could explain the interior concepts of the soul with it, and communicate them to the other individuals in his species" ("la lengua, para que con ella pudiesse explicar los conceptos interiores del alma, y comunicarlos con los demas indiuiduos de su especie"). ${ }^{14}$ Córdova then turned to received wisdom by stating that Hebrew was the first language of the world, and that, following the division at Babel of Hebrew into seventy-two tongues, these in turn subdivided into the "innumerable" languages of the world. Therefore ministers could not rely on interpreters to translate their preaching, because through such mediation "doctrinal teachings lose a great deal of its being, authority, and strength" ("la doctrina pierde gran parte de su ser, autoridad, y fuerça”). ${ }^{15}$

In addition, Córdova argued for a subtle but decisive reversal of the hierarchical place usually granted to Latin. He noted that, since the study of Latin was "a higher science" ("sciencia mas subida"), some of his dictionary's readers might conclude that he had laboured less than European lexicographers (voc[a]bulistas) and grammarians like the influential Ambrogio Calepino, who was widely regarded as a standard lexicographical model. Córdova claimed, nonetheless, that the inverse was closer to the truth. Calepino's labours, which were limited to consulting books, comparing authors, and ordering items of vocabulary, paled in comparison with Córdova’s painstaking lexicographical work. In fact, Córdova argued, he and his colleagues had laboured even more, or at least as much as those acclaimed authors. They had been "unearthing words from the dust of oblivion, negligence, oversight, and lack of use, among such a wild and not too bright people; over days and nights, we did our utmost to reveal [these words'] exact meanings . . . verifying them through

\footnotetext{
${ }^{14}$ Juan de Córdova, Vocabulario en lengua Çapoteca (Mexico City: Pedro de Ocharte and Antonio Ricardo, 1578), fol. v r.

${ }^{15}$ Córdova, Vocabulario, fol. viii v.
} 
experience" (“desenterrando vocablos de entre el poluo del oluido, negligencia, y inaduertencia, y poco uso, y e[n]tre tan bronca y no muy despierta gente[;] ha sido dias y noches desuelarnos en desentrañar sus mero significados . . . verificandolos con la experiencia"). ${ }^{16}$

\section{Catechetical Strategies in Feria's Doctrina}

The colonial Zapotec catechetical sources record the lexicon and usage of two of four major branches of Zapotec — that is, the Central (Valley) and Northern branches. Coverage of Isthmus Zapotec is minimal, and there is no coverage of Southern Zapotec. By contrast, mundane records such as wills, petitions, and town council statements reflect local variation. ${ }^{17}$ Dominican lexicographers did not systematically represent important phonological features of Zapotec, including tone and a distinction between 'strong' and 'weak' consonants, but addressed its complex verbal morphology. ${ }^{18}$ As observed by Thomas Smith-Stark, the "catechetical trilogy" of grammars, vocabularies, and catechisms in Mesoamerican languages tended towards standardisation; he has noted in particular the

\footnotetext{
${ }^{16}$ Córdova, Vocabulario, fol. ix v.

${ }^{17}$ For Zapotec language classification, see Thomas Smith-Stark, 'Algunas isoglosas zapotecas', in Christina Buenrostro etc. (eds.), Memorias del III Coloquio Internacional de Lingüística Mauricio Swadesh (Mexico City: UNAM, INI, 2007), pp. 69-134; G. Aaron Broadwell, 'The Historical Development of Progressive Aspect in Central Zapotec', International Journal of American Linguistics 81 (2015), pp. 151-185.

18 Thomas Smith-Stark, 'Phonological description in New Spain', in Otto Zwartjes and Cristina Altman (eds.), Missionary Linguistics II / Lingüística Misionera II: Orthography and Phonology (Amsterdam: John Benjamins, 2005), pp. 3-64. Also by Smith-Stark see 'La flexión de tiempo, aspecto y modo en el verbo del zapoteco colonial del valle de Oaxaca', in Áurea López Cruz and Michael Swanton (eds.), Memorias del Coloquio Francisco Belmar (Oaxaca: Biblioteca Francisco de Burgoa, 2008), pp. 377-419, at p. 380.
} 
codification of Zapotec orthography, which did not reflect known regional variations. ${ }^{19}$

It is difficult to overstate the importance of Pedro de Feria's 1567 Doctrina as a foundational text for Zapotec Christian discourse. This work introduced a novel lexicon that was systematically adopted in nearly immutable ways by later doctrinal texts. It also embraced a clear departure from the Christian lexicon employed in another influential early Dominican work, the 1548 Nahuatl-language Doctrina. Feria served as vicar of Teiticpac, a Oaxacan district in which an important early idolatry trial and public punishment was carried out. ${ }^{20}$ Feria, a native of Extremadura in Spain, was educated in the liberal arts and theology at the University of Salamanca, and was made a vicar in 1550, at twenty-six years of age. ${ }^{21}$ After arriving in Mexico, he spent most of his time as vicar of Teiticpac. ${ }^{22}$ During a period of thirteen years, according to the Dominican chronicler Francisco de Burgoa, Feria "persevered in the study of the Zapotec language in such depth and comprehension that he wrote a Christian doctrine in it ... with such proper words, significant terms, and clarity in speech, that although ninety years have passed since its printing, there has been no need to correct any of its words or phrases". ${ }^{23}$

In a show of humility, Feria gives much credit to a previous manual composed by his co-religionist Bernardo de Albuquerque, who was Bishop of Oaxaca between 1562 and 1579.

\footnotetext{
${ }^{19}$ Thomas Smith-Stark, 'La trilogía catequística: artes, vocabularios y doctrinas en la Nueva España como instrumentos de una política lingüística de normalización', in Rebeca Barriga Villanueva and Pedro Martín Butragueño (eds.), Historia sociolingüística de México (Mexico City: Colegio de México, 2007), pp. 607-647. ${ }^{20}$ Francisco de Burgoa, Geográfica descripción (2 vols., Mexico City: Editorial Porrúa, [1674] 1989), I, p. 169. See also David Tavárez, The Invisible War: Indigenous Devotions, Discipline, and Dissent in Colonial Mexico (Stanford, CA: Stanford University Press, 2011), pp. 57-58.

${ }^{21}$ Burgoa, Geográfica descripción, II,, p. 74.

${ }^{22}$ Burgoa, Geográfica descripción, II, p. 76.

${ }^{23}$ Burgoa, Geográfica descripción, II, pp. 184-186.
} 
In the prologue to his Doctrina, Feria states that he composed it with the assistance of "the doctrina that Your Excellency [Bishop Albuquerque] made in that same Zapotec language". ${ }^{24}$ This observation is of capital importance, since Feria suggests here that some elements from his Doctrina were drawn from one of the most important early catechetical Zapotec manuals: a Doctrina authored by Bishop Albuquerque, which is no longer extant. ${ }^{25}$ Any contributions drawn from Albuquerque's work would have been based on decades of missionary and lexicographic labour. Albuquerque rose slowly through the ranks of his order, and perfected his Zapotec while living as a missionary in Northern Oaxaca. His career reached its zenith when he was consecrated Bishop of Oaxaca in 1562, having served as his order's Provincial and Prior in Oaxaca. As for Feria, he was named Prior and then Provincial of the Dominican house in Mexico City. Like the career of Albuquerque, Feria's career was capped by elevation to a bishopric, that of Chiapas. This last phase of his work is perhaps best known for his participation, through written opinions, at the 1575 Second Mexican Church Council, and for his investigations into an idolatrous native "confraternity" in $1584 .^{26}$

Indigenous colonial subjects proved their standing as good Christians by learning and reciting prayers in their own languages, which usually included, besides prayers to God the Father and Mary and the Apostle's Creed, the commandments, articles of faith, and confession, followed by lists of sacraments, sins, works of mercy, and other secondary

\footnotetext{
${ }^{24}$ Pedro de Feria, Doctrina christiana en lengua castellana y çapoteca (Mexico City: Pedro Ocharte, 1567), Prologue, fol. iii v.

${ }^{25}$ For Albuquerque's influential career, see María del Carmen Martínez Sola, El obispo fray Bernardo de Albuquerque. El marquesado del valle de Oaxaca en el siglo XVI (Oaxaca and Mexico City: Instituto Oaxaqueño de las Culturas, 1998).

${ }^{26}$ Pedro de Feria, 'Relación que hace el obispo de Chiapas', Anales del Museo Nacional de México 6 (1899), pp. 481-487. Feria convalesced from a leg injury in Oaxaca City while the Second Council was in session; see Burgoa, Geográfica descripción, II, p. 81.
} 
teachings. Feria's Doctrina designated Christian teachings through the phrase ticha nalij, "the true word", and employed the polyvalent term ticha, which referred to an oral or written act of speech, and which Córdova glossed variously as "word" $\left(297^{\mathrm{v}}\right)$, "saying” (138 $)$ "writing" $\left(182^{v}\right)$, "language" $\left(211^{v}\right)$, “message" $\left(264^{v}\right)$, "reasoning" $\left(341^{v}\right)$, and "vernacular" $\left(362^{v}\right)$.

The major sections in Feria's Doctrina are written as relatively short accounts on thirty-eight or so different catechetical topics, which allowed for their use in narrative preaching, a form of instruction that Dominicans had long privileged, along with rhetorical brilliance. ${ }^{27}$ Feria's work divides catechesis into "five capital sayings" (cayo quiquie ticha) by order of importance. ${ }^{28}$ Remarkably, Feria allocates first place to a teaching that was less prominent place in other catechisms: the Fourteen Articles of the Faith, tersely translated as "the fourteen parts ... called the Articles of the Faith" ("chitaa xibaa ... nilaa Articulos de la fee"). After this major devotion—given an importance echoed, as shown below, in many Zapotec wills - comes the Apostle's Creed (Tiyelijlachia). As the second point there follow the Our Father (Bixocena e); the Hail Mary (Anna chana Maria e), and the Salve Regina (Anna chana Maria xonasi coqui quiebaa e). The Ten Commandments; the Five Commandments of the Church; the fourteen works of mercy; the theological and capital virtues; the virtues opposed to the mortal sins; the five senses; the three powers of the soul, and the seven "gifts" (xillaa) of the Holy Spirit are listed as the third doctrinal "word". As his last two points, Feria addresses the mortal sins, the enemies of the soul, and the remedies for

\footnotetext{
${ }^{27}$ For instance, for thirteenth-century Dominican sermons and exempla, see Christine Caldwell Ames, Righteous Persecution: Inquisition, Dominicans, and Christianity in the Middle Ages (Philadelphia: University of Pennsylvania Press, 2013), p. 42. While the Dominicans had a well-earned reputation for preparing and delivering sermons, both the Ordo Praedicatorum and the Franciscans employed short, simple, set pieces as admonitions or brief sermons.

${ }^{28}$ Feria, Doctrina, fols. $11^{\mathrm{v}}-12^{\mathrm{v}}$.
} 
venial and mortal sins. A final section without Spanish translation reprises the major prayers and sets down a brief catechetical dialogue.

\section{Recasting Zapotec Political and Cosmological Terms into Christian Discourse}

Some of Feria's translations resemble the linguistically adept but cautious Dominican solutions in the 1548 Nahuatl Doctrina: both texts introduce the Christian God with the Spanish borrowing Dios, employ preconquest ruler's titles for God and Christ, adopt terms from native cosmologies to describe a Christian universe, and emphasise the purity of Mary. However, as discussed below, Zapotec translations diverged from those in Nahua in two important ways: firstly, in terms of expressive possibilities through multiple terms for "sin", and for God, Christ, and Mary as rulers; secondly, in referential terms, since they chose different discursive means for framing idolatry and the Devil.

In Zapotec, the Christian God was referenced by means of a Spanish borrowing, Dios, and often appeared as "the deity God" (Bitoo Dios), "the true God" or "truly God" (Dios pitào nalij; Dios balij betaao; hualijca bitoo), while non-Christian deities became "evil gods" (bitoo xihui). Bixoce (father) was used to qualify God as Father, and as a term for addressing Dominican clergy. To denote the authority of God, Christ, and Mary, several titles were used. The most common of these was bejoana, "master (or lord) of a household, of a family, or of anything", while chana and its variant pechana, "lord of slaves, lineage lord" were also used, and coqui, "lineage lord, ruler" emphasised rulership over heaven or earth. ${ }^{29}$ Some sources claimed chana as a vocative form of bejoana. ${ }^{30}$ All of these titles were gender-neutral, and in addition Mary was also called xonasi, "lady".

\footnotetext{
${ }^{29}$ These glosses appear in Córdova, Vocabulario, fol. $377^{\mathrm{r}}$.

${ }^{30}$ Alonso Martínez, Manual breve y compendioso para empesar a aprender lengua çapoteca, John Carter Brown Library, Providence, Codex Ind. 70, [1633] 1872, 37; Leonardo Levanto, Cathecismo de la doctrina
} 
The favoured title for God and Christ was bejoanana in Valley, and xana reheo in Northern Zapotec. This title employed the unusual referential property of a first person inclusive plural (-na), which could refer to both the speaker and those being addressed-in contrast with a first person exclusive plural, which did not have that property. ${ }^{31}$ Hence, if taken literally, the ubiquitous Bejoanana Dios meant "God, the lord of us all, including anyone addressed by this phrase". Feria and other Dominicans took note of this special pronoun. Its properties are mentioned by Córdova in his Arte, with the explanation that -na was also a reverential form similar to "Your Excellency". ${ }^{32}$ In his early eighteenth-century Arte, Gaspar de los Reyes would note that Northern Zapotec had the pronoun -reheo instead of -na, which he described as a "more comprehensive" and reverential pronoun. Reyes did observe, however, that Zapotec speakers used the exclusive and inclusive pronouns interchangeably, except when addressing God. He also emphasised that speakers did not always interpret -reheo as an inclusive - for when they said, "Oh God, deliver us" (becilaci reho xana Dios he), they could not include God as one to be delivered from sin, and added, "no, the Indians are not that metaphysical". 33

In Nahuatl, "sin" became tlahtlacolli, a term referring to things that were damaged, displaced, or off balance. ${ }^{34}$ This concept was translated in Valley Zapotec through four

christiana en lengua zaapoteca (Puebla: Viuda de Miguel de Ortega, 1766), fol. $3^{\mathrm{r}}$.

${ }^{31}$ This property, known as clusivity, is a feature of indigenous languages in the Americas such as Aymara, Quechua, and Guaraní, and also exists in several Austronesian and Dravidian languages. See Elena Filimonova, (ed.), Clusivity: Typology and Case Studies of the Inclusive-Exclusive Distinction (Amsterdam and Philadelphia: John Benjamins, 2005).

32 Juan de Córdova, Arte en lengua zapoteca (Mexico City: Pedro Balli, 1578), fol. $57^{\mathrm{v}}$.

${ }^{33}$ Gaspar de los Reyes, Gramática de las lenguas Zapoteca-serrana y Zapoteca del Valle (Oaxaca: Imprenta del Estado, [1704] 1891), pp. 17-18.

${ }^{34}$ Burkhart, Slippery Earth, pp. 28-29. 
lexical items belonging to a single semantic field: tola / tolla, xihui, tee, and quia. Córdova employed all four terms to refer to "guilt" and glossed "evil" as tee or tola, and "iniquity" as quia or tee. ${ }^{35}$ In particular, tola resonated deeply with Zapotec Christians due to a preconquest ritual involving a plant called tòla, which was fashioned into short lengths of rope that were placed by penitents before a ritual specialist (pigana), each standing metonymically for a single, specific transgression. ${ }^{36}$ The chronicler Burgoa also mentions a similar practice, involving cornhusk strands rather than pieces of tòla, which was witnessed during a 1652 visit to San Francisco Caxonos. ${ }^{37}$ The word xihui was often deployed as an adjective for evil actions or bad things, as opposed to chahui, "good"; in addition, xihui was also contrasted with nalij, "true, straight". 38

Unlike all other terms for sin, the root xihui was sometimes used to form various verbal or nominal phrases. For instance, Feria has “you did something evil” (pexihuilo); Córdova records "I sinned" (toxihuia); many versions of the Second Commandment, beginning with Feria, render it as a prohibition to take God's name "in an evil way" (cogoona xihuilo), and the constructions "person who does evil" (benni huexihui) or "iniquity" (quela huexihui) appear in most sources. ${ }^{39}$ The term tee often appears paired with tola in couplets in various Zapotec doctrinal texts, while quia was a far more restricted term for sin —it only appears in Córdova's dictionary and in a work published in 1666, Cristóbal de Agüero's

\footnotetext{
${ }^{35}$ Córdova, Vocabulario, fols. $234^{\mathrm{v}}$ and $254^{\mathrm{r}}$.

${ }^{36}$ Córdova, Vocabulario, fol. $228^{\mathrm{v}}$.

${ }^{37}$ Burgoa, Geográfica descripción, II, pp. 228-231; Tavárez, Invisible War, p. 106.

${ }^{38}$ See, for instance, Córdova, Vocabulario, fol. $182^{\mathrm{v}}$, which distinguishes between true (nalij) and false (xihui) writings.

${ }^{39}$ Feria, Doctrina, fol. $49^{\mathrm{v}}$; Córdova, Vocabulario, fol. $306^{\mathrm{r}}$. For the Second Commandment, see Feria, Doctrina, fol. $67^{\mathrm{v}}$, and Francisco Pacheco de Silva, Doctrina Christiana en lengua Zapoteca Nexitza (Mexico
} City: Francisco Sánchez, 1687), fol. $6^{\mathrm{r}-\mathrm{v}}$. 
Misceláneo espiritual. ${ }^{40}$ Hence the vocabulary for sin opened up multiple expressive choices for rendering the distinctions among mortal, venial, and original sin.

\section{Feria on Idolatry: From Aquinas to Zapotec Images}

In his Doctrina, Feria provides a canonical — and highly memorable — translation for the notion of idol worship: "making, and being taught by, stone and wood deities" ("quela huezaa, quela huecete bitoo quie, bitoo yàga"). This trope relied on an important derivational process for Zapotec verbs in order to ridicule worshippers of pre-Conquest deities. Feria's translation literally rendered "idolatry" as the fashioning of effigies, which then imparted their false teachings upon those who had fashioned them. ${ }^{41}$ Such a solution departed significantly from one of the earliest translations of "idolatry" into Nahuatl; found in the 1548 Dominican Doctrina, this translation was the phrase "following something as a deity" (tlateotoquiliztli). Feria's rendering created a formidable intertextual link rooted in the history of Israelite faithlessness to their only deity — as set forth in several passages of scripture. It

\footnotetext{
${ }^{40}$ These Zapotec terms for "sin" appear, for instance, in Feria, Doctrina, fol. $55^{\mathrm{r}}$ (tola tee); in Levanto, Catechismo, p. 15; and in Pedro de la Cueva, Parábolas y exemplos sacados de las costumbres del campo, Bibliothèque National de France, Collection Pinart, Fonds Américain 70, fol. $10^{\mathrm{r}}$ (teela tollala). For quia, see Córdova, Vocabulario, fols. $306^{\mathrm{r}}$ and $234^{\mathrm{v}}$; see also Cristóbal de Agüero, Misceláneo Espiritual en el idioma Zapoteco (Mexico City: Francisco Rodríguez Lupercio, 1666), under the heading "Joyful Mysteries", fol. 1". ${ }^{41}$ Feria, Doctrina, fol. $60^{\mathrm{v}}$. The variant "making, and then being taught, by stone and wood" appears at fol. $65^{\mathrm{r}}$. Córdova, Vocabulario, translates quela huezaa variously as "active making, fashioning" (hazimiento o hechura activa, fol. $215^{\mathrm{r}}$ ), as "siring, procreation" (engendramiento, fol. $166^{\mathrm{v}}$ ), and, in a graphic turn, as "skewering" (espetamiento, fol. $\left.186^{v}\right)$. Quela huecete is a "passive" form of teaching (enseñamiento passiuo, fol. $172^{\mathrm{r}}$ ). By "passive" and "active", and by using the term "compulsive" for the former class in his Arte (53), Córdova was referring to the anticausative and causative forms of Zapotec verbs, as analysed in Smith-Stark, 'La flexion', pp. 383-388. Hence, the anticausative quela huecete means "being taught" while its causative form quela hue-cocete is "teaching".
} 
departs from the narrative about the worshippers of the golden calf in Exodus 32:1-28, then echoed various sections (such as Isaiah 40:18-20, 44: 9-20; Jeremiah 10:1-5; and Habakkuk 2:18-19) that denounced and mocked the desire of idolaters to elevate images of stone and wood to the status of deities. ${ }^{42}$

Feria's neologism also seems to have been inspired by an influential passage in Wisdom 14: 7-8, which contrasts the "blessed" wood used for just ends with the "cursed" idol made by human hands. Even further, Feria's phrase evokes Aquinas's discussion of Proverbs 21, which locates the origins of idolatry in the ancient custom of making images of wood and stone for deceased rulers. ${ }^{43}$ In another, and pointedly patriarchal, denunciation of the consequences of idolatry, Feria argued that native mortality due to epidemics was God's punishment inflicted on the Zapotec people. They stood before God as an unfaithful wife who needed to be disciplined by her husband. Through this example, Feria alluded to the denunciation of Israel as God's unfaithful consort in Ezekiel 16:27-30 and Hosea 1:1-2. Two catechetical manuals in Nahuatl-language previously published by the Dominicans - the 1548 Doctrina, and Domingo de la Anunciación's 1565 Doctrina-circumvented a detailed discussion of idolatry, and did not employ the trope of stone or wood images to convey the notion of idolatry. ${ }^{44}$ Feria's discussion of idolatry in his Doctrina stands out for two reasons. Not only did it engage in a full explanation of the origins of idolatry; it also went beyond a gloss of the received narrative drafted by Aquinas. Through a firm embrace of Thomism,

\footnotetext{
${ }^{42}$ For a discussion of this trope in the Old Testament, see Moshe Halbertal and Avishai Margalit, Idolatry (Cambridge MA: Harvard University Press, 1992), p. 19. For a different analysis of Feria's translation of “idolatry” see Farris, Libana, pp. 119-120.

${ }^{43}$ Thomas Aquinas, Summa theologiae (Rome: Marietti, 1948), p. 481.

${ }^{44}$ In the first Dominican Nahuatl Doctrina, the term "following something as a deity" appears only four times. See Dominican Order, Doctrina Christiana en le[n]gua española y mexicana (Mexico City: Juan Pablos, [1548] 1550), fols. $124^{\mathrm{v}}, 128^{\mathrm{v}}, 130^{\mathrm{r}}$, and $145^{\mathrm{r}}$.
} 
Feria presented a specific thesis concerning the origins of Zapotec idolatry that departed from more general euhemeristic explanations deployed by various commentators and theologians. ${ }^{45}$ Feria was neither the first nor the only Dominican to adapt the work of Aquinas into an indigenous language. In the middle years of the sixteenth century, in the region now known as Guatemala, the Dominican Domingo de Vico prepared a lengthy manuscript entitled Theologia indorum, which adapted into K'iche' Maya many teachings from Aquinas's Summa theologica. ${ }^{46}$

Moreover, in Central Mexico, the influential Franciscan scholar Bernardino de Sahagún also turned to Aquinas in his appendix to Book I of The Florentine Codex, an encyclopedic work on Nahua history, language, and society compiled between the late 1540s and the late 1570s. While the main content of Book I describes Nahua deities, the appendix turns to a protracted refutation of idolatry in Nahuatl. Like Feria, Sahagún emphasized the falsity of wooden idols, provided a loose adaptation of Aquinas' argument on idolatry's causes, and cited Wisdom 14 in support of his argument. Unlike Feria, Sahagún underlined Aquinas's discussion of human nature as a cause, such as the remembrance of the dead and the beauty of images, even if he did characterize the sway false deities had over the Nahua as inspired by the Devil. ${ }^{47}$ In the end, Feria did go further in terms of his appropriation of

\footnotetext{
${ }^{45}$ Feria, Doctrina, fols. $61^{\mathrm{r}}-63^{\mathrm{v}}$. On euhemerism, see Jean Seznec, The Survival of the Pagan Gods (Princeton: Princeton University Press, 1953), and Frank Lestringant, 'The Euhemerist Tradition and the European Perception and Description of the American Indians', in Wolfgang Haase and Meyer Reinhold (eds.), The Classical Tradition and the Americas (2 vols., Berlin: Walter de Gruyter, 1993), pp. 173-188.

46 The Dominican Domingo de Vico employed elements from K'iche' Maya cosmological narratives in his manuscript Theologia indorum. See Garry Sparks and Frauke Sachse, ‘A Sixteenth-Century Priest's Field Notes among the Highland Maya: Proto-Theologia as Vade mecum', in Tavárez, Words and Worlds, n.p. ${ }^{47}$ Sahagún, Bernardino de, The Florentine Codex, Book 1: The Gods, trans. and ed. Arthur J. O. Anderson and Charles E. Dibble (Salt Lake City: University of Utah Press, 1950-1982), pp. 58-59 and 69.
} 
Aquinas. While Vico's and Sahagún's Thomistic commentaries remained in manuscript form, Feria was the first author to gloss Aquinas's work in a printed work and in an Amerindian language.

In his Summa theologica, Aquinas analysed two causes of idolatry: human nature and human actions (dispositiva), and the interventions of the Devil (consummativa). Furthermore, Aquinas divided the dispositiva into three explanations. First of all, he refers to the disordered love (ex inordinatione affectus) between parents and children that leads to the creation of images that remind survivors of their beloved dead. Afterwards, there is the worship of carefully crafted, beautiful images. At the end comes worship arising from the ignorance of the true God, motivated by the beauty and power of creatures. ${ }^{48}$ Feria revealed his reverence for Aquinas's explanation by interweaving both the causa dispositiva and the causa consummativa in a Zapotec narrative that also recognised the influence of another important Dominican: friar Antoninus, who was Archbishop of Florence from 1436 until his death in 1459 .

So as to isolate the roots of idolatry's causa dispositiva, Aquinas quoted from Wisdom 14:15: "For a father afflicted with bitter grief made for himself an image of his son, who was swiftly taken away. And him who had then died as a man, he now began to worship as a deity" ${ }^{49}$ Feria appropriated this explanation and rendered it thus in Zapotec:

Cotobi loo còca cicatij, quelani toti beni natij xinì nachijni: chicani tebela còti xinini nachijni, citao tete pelacelachini, chela piñaxoolàchini, niateni xiquela côti xini nachijni:

\footnotetext{
${ }^{48}$ Aquinas, Summa theologica, pp. 481-482 [Secunda Secundae, Quaestio 94].

${ }^{49}$ Aquinas, Summa theologica, pp. 481-482: Acerbo luctu dolens pater, cito sibi rapti filii fecit imaginem; et illum qui tunc quasi homo mortuus fuerat, tamquam deum colere coepit.
} 
. . cani nacacîquie, nacacîyaga penichàhuini tobi loâ,

tobi bennabi xiteni quettoo xînini,

laaca loà canî, bennabi canî copachahuilichini: niani ca[n]nani looni,

cica yobi xinini coca lachini beni cani loà canî,

laaca bennabi canî pebaquini, peguichilachitaoni. ${ }^{50}$

(The first one was as follows: Because a person has a dear child who dies.

If [this person's] dear child died, he grew very sad,

and he became angry upon the death of his dear child.

... And he fashioned well an image of stone, of wood,

a representation of [the child], his child's sepulcher,

and he kept well in his house that very image, that representation, so that before it, it was as if the child was in the person's heart only as an image.

As he set up that representation, he grew much stronger.)

As the previous passage shows, Feria's translation emphasises the emotions cited by Aquinas: the father in the narrative tete pelacelachini, "grew very sad". This verb is closely related to a Christian view of Zapotec emotions, as Córdova's dictionary also glosses it as “to become contrite", an act that would take place after a sinner confronted his transgressions. ${ }^{51}$ Additionally, Feria stresses that this image brings solace, but also made early idolaters peguichilachitaoni, or "grow much stronger". Throughout his explanations, Feria uses the couplet "wood, stone" in the manner of a martinet, to drive home the idea of idols as dead matter. He is careful not to identify Ninus's misguided love for his father Bel as the origin for this narrative; he also avoids Aquinas's various references to early idolaters, such as Nimrod,

\footnotetext{
${ }^{50}$ Feria, Doctrina, fol. $61^{\mathrm{r}}$.

${ }^{51}$ Córdova, Vocabulario, fol. $91^{\mathrm{r}}$ : To be contrite. Telacelachia.
} 
Prometheus, and Ismael, since these names would require a far more detailed account of Biblical antiquity.

In his summation of the dispositiva, however, Feria seems to incur a debt not only to Aquinas, but to Antoninus of Florence, another Dominican theologian who wished to denounce the excessive love between parents and children, and children and parents, as the root of idolatry. An influential scholar and preacher, Antoninus offered the following reflection in a chapter of his Summa theologica, concerning the various effects of the "passions of the soul", including love:

O quot sunt parentes, qui propter inordinatum amorem ad filios, damnationem incurrunt! O quot sunt, qui eis quasi idolis inserviunt! Et nota, quod idololatria habuit initium ab inordinato amore parentum in filios, $\&$ e converso. ${ }^{52}$

(Oh, how many parents exist who earn damnation due to an irregular love for their children! Oh, how many of them serve [their children] like idols! And notice that idol worship has had its beginning in the disordered love of parents for their children, and conversely.)

Feria's distillation of Aquinas's dispositiva comes in a single sentence that recalls some of Antoninus's words:

Cicatij peni beni cani, colaça, chi còti xinini: chela chi côti bixoceni. ${ }^{53}$

\footnotetext{
${ }^{52}$ Antoninus of Florence, Summa theologica (Verona: Agostino Carattoni, 1790), p. 432 [Titulus 5, Capitulus II].

${ }^{53}$ Feria, Doctrina, fol. $61^{\mathrm{r}}$.
} 
(People in antiquity acted in this way, at the time when their children died, and at the time when their fathers died.)

Feria also took Aquinas's carefully calibrated set of arguments, laid out in order, and shuffled them in order to arrange them into a more compelling narrative for Zapotec neophytes. After discussing the images born of the disordered love of parents for their children, he noted that eventually men started to kill human beings before these images (pètini benì looni) and "tied up their ears and tongues" (cozòba tiàgani xitichani) as acts of self-sacrifice. In order to explain the growth in such "evil" (quela naxihui), Feria then turned to idolatry's second cause. Aquinas held that the causa consummativa came

ex parte daemonum, qui se colendos hominibus errantibus exhibuerunt in idolis, dando responsa et aliqua quae videbantur hominibus mirabilia faciendo. Unde et in Psalm [95:5] dicitur: "Omnes dii gentium daemonia". 54

(from the part of demons, who showed themselves so as to be worshipped by men, by giving answers in the idols, and doing other things that seemed marvelous to men. Hence, it is said in Psalm [95:5]: "All the gods of the Gentiles are demons”.)

This explanation Feria rendered as

quelani ciani liaça coyaci yobi bezeloo lani loà yagala, quiela, tuacani co[n]nî tichani, pichiba pij, pichiba ticha xiteni bezeloo, tua loà canî. ${ }^{55}$

\footnotetext{
${ }^{54}$ Aquinas, Summa theologica, p. 482 [Secunda Secundae, Quaestio 94].
} 
(because many times the Devil entered their images of wood, of stone;

in that place he spoke, and the words, the breath of the devil came out, at the image's mouth.)

Having sketched the Devil's participation in the emergence of idolatry, Feria then returned to Aquinas' dispositiva, which quoted Wisdom 14:21 thus: "“for men serving either their affection or their kings, gave the incommunicable name' that is, the Divinity's, 'to stones and wood". 56 The Oaxacan Dominican took this relatively brief citation as a point of departure for a narrative about how vainglorious rulers had commissioned images to memorialise their existence:

Quelani layoo colaça tete cecha cue coquij reyes queche layoo,

... Chicani pitîe ticha peà xitenini, coyè xitichani quitobi xilayooni, conâ peani, quita lij xiguecheni capani loà xitenini, cij nachijni quitaa lij beni xiloàni.

Cicatij cij nachini yobi coquî: laaca loâ cani pitaque ni xibitooni beniati, pizaalij (chi pitabîga layoo. $)^{57}$

(Because in the very ancient lands, those other rulers and kings of Earth ... their command came out, their word was painted on all their lands, and they understood

\footnotetext{
${ }^{55}$ Feria, Doctrina, fol. $62^{\mathrm{r}}$.

${ }^{56}$ Aquinas, Summa theologica, p. 481 [Secunda Secundae, Quaestio 94]: homines, aut affectui aut regibus deservientes, incommunicabile nomen, scilicet divinitatis, lignis et lapidibus imposuerunt.

${ }^{57}$ Feria, Doctrina, fol. $63^{\mathrm{r}}$.
} 
[that] all of their towns were to keep images of them, and all the people revered their images.

Thus the rulers would [be] revered, and thus these images arrived as the gods of the people, thus they went (and that time arrived on Earth. ${ }^{58}$ ))

Through an overview of language and evangelisation policies for the Zapotecs of Oaxaca in the sixteenth century, this chapter has stressed three major Dominican strategies: an appropriation of lexical knowledge and Zapotec terms for the social and cosmological order, a reorganised moral discourse, and a closely justified rupture with idolatry. This chapter has also emphasised Dominican orthodoxy, since this order's regimented evangelisation policies in New Spain preceded the focus on catechetical instruction and orthodox use of scripture mandated by the Council of Trent. Like the Franciscan order in Central Mexico-and in a move that echoes the strategic flexibility of other missionaries in the sixteenth century-the Order of Preachers walked a tightrope between diminishing and selectively embracing indigenous cosmology and moral discourse.

With regard to translation, this chapter has emphasised a unique approach to evangelisation in Feria's Doctrina, namely Feria's careful adaptation of an important section in Aquinas's Summa theologica on the origin of idolatry. Such an analysis can only emerge from a close philological and semantic analysis of texts in colonial Zapotec, and from a comparison of these texts with potential sources and influential opinions written by theological auctoritates. Feria did not merely recapitulate or gloss Aquinas's opinion: he

\footnotetext{
${ }^{58}$ Córdova, Vocabulario, fol. 22 v : For someone to arrive close to me, to go approaching. Cetabijgalo, pita. [ve]l. zetabijgani.
} 
rearranged its components with the aim of presenting a logical, linear narrative for Zapotec Christians. This narrative was based on an appraisal of the common ground shared by European and Zapotec idolaters, and it was thoroughly congruent with two important theses held by the Dominican Bartolomé de las Casas: that all peoples, and not only Christians, could access God and natural knowledge, and that pagan practices were but imperfect forms of Christian ones. ${ }^{59}$

Feria was noticeably careful to set forth a scenario for the origin of idolatry, and the need for its rejection, that was not based in specific references to Zapotec cosmology. The very language used in catechesis recruited terms that had multiple connotations in Zapotec religion and history. Even so, Feria's narrative about idolatry, unlike the work of his coreligionists in Nahuatl, did not mention Zapotec deities, and nor did it set down a detailed analysis of Zapotec ritual practices. ${ }^{60}$ In fact, Feria was seeking a common ground that bound a Thomistic understanding of idolatry with the perceptions and feelings that Zapotecs were asked to embrace as new Christians. To do so, he went beyond Aquinas's teachings on idolatry, and identified the misguided love between parent and child as idolatry's root, thus echoing an opinion articulated by Antoninus of Florence. In the end, from Feria's vantage point, a focus on a common ground shared by Zapotec and European understandings, carefully delimited through translation choices, seemed the most promising strategy for producing Zapotec Christianity in the late sixteenth century.

\footnotetext{
${ }^{59}$ Bartolomé de las Casas, Apologética historia sumaria (Mexico City: UNAM, 1967), p. 539; see also Fernando Cervantes, The Devil in the New World (New Haven: Yale University Press, 1994), pp. 31-33.

${ }^{60}$ See the Dominican Doctrina, fol. $25^{\mathrm{r}}$, which denounces several Nahuatl deities by name as false ones: Huitzilopochtli, Tezcatlipoca, Chicomecoatl, the Tlaloque (water deities), Titlacahuan (an epithet for Tezcatlipoca), and Xiuhteuctli.
} 


\section{CHAPTER 8}

\section{Paratextual economies in Tudor women's translations: Margaret More Roper, Mary Roper Basset and Mary Tudor}

\section{Rosalind Smith}

In sixteenth-century England, translation was far from a marginal activity. Rather, it was the vehicle through which the literary and scholarly heritages of the distant and immediate past were assimilated into the vernacular. This process encompassed the humanist project that saw the Tudor translation of foundational classical texts, the translation of texts from the Italian, French, and Spanish Renaissances, and, most significantly, the translation of the Bible into English—newly making the Scripture available to a broad range of readers as well as generating a multitude of other kinds of religious texts. Such translations were read by an emergent class of literate women, who also played an active part in the production of these texts: both religious and secular translations constituted one of the dominant forms of early modern women's literary output. ${ }^{1}$ Understanding this seemingly counter-intuitive relationship of cultural capital and female activity has underpinned much of the scholarship on early modern women and translation. Initially conceived as a qualified site of agency for women due to the mediation of their voices through an authorised text, the practice of translation has been reinterpreted in the last decade as an important vehicle for women's strategic interventions in familial, political, and religious networks and

\footnotetext{
${ }^{1}$ Danielle Clarke, 'Translation', in Laura Lunger Knoppers (ed.), The Cambridge Companion to Early Modern Women's Writing (Cambridge: Cambridge University Press, 2009), pp. 167-180, at p. 168. See Brenda Hosington for a correction of assumptions about the proportion of religious and secular translations by women: Brenda Hosington, 'Translation and Women Translators', in Diana Robin, Anne R. Larsen, and Carole Levin (eds.), The Encyclopedia of Women in the Renaissance: Italy, France and England (Santa Barbara: ABC-Clio Press, 2007), pp. 369-373, at pp. 370-371.
} 
debates. ${ }^{2}$ This revisionist work has overlapped with a new attention to the materiality of early modern women's writing, which has foregrounded new physical sites of writing, genres, and modes of transmission, as well as revaluing a wider range of roles for women in textual production, including that of the translator. ${ }^{3}$ This collision of approaches from book history, material analysis, and gender studies in recent scholarship on early modern women's translation generates inevitable critical biases, privileging some paratextual elements and roles over others, and at times reproducing conservative models of early modern women as silent and silenced. Drawing on materialist models of publication as event and text as archive, this chapter focuses on neglected material elements of three translations by a group of early sixteenth-century Catholic women writers in England - Margaret More Roper, Mary Roper Basset, and Mary Tudor - in order to reconsider the extent of these texts' political engagements across multiple textual sites. It asks what the paratexts of these translations (broadly defined to encompass image and marginalia as well as dedication and preface), tell us about women and religion, women as writers and readers, and women as agents within political, religious, social, and material cultures of textual production.

\section{Expanding early modern women's translation: authorship, materiality and the}

\section{history of the book}

\footnotetext{
${ }^{2}$ The first view can be located in early feminist scholarship such as Mary Ellen Lamb, 'The Cooke Sisters: Attitudes towards Learned Women in the Renaissance', in Margaret P. Hannay (ed.), Silent but for the Word: Tudor Women as Patrons, Translators and Writers of Religious Works (Kent, OH: Kent State University Press, 1985), pp. 107-125, and Tina Krontiris, Oppositional Voices: Women as Writers and Translators of Literature in the English Renaissance (London: Routledge, 1992). For one of many revisions see Suzanne Trill, 'Sixteenth-Century Women's Writing: Mary Sidney's Psalms and the "Femininity" of Translation', in Suzanne Trill and William Zunder (eds.), Writing and the English Renaissance (New York: Longman, 1996), pp. 140-158, and Danielle Clarke, The Politics of Early Modern Women's Writing (Harlow: Longman, 2001), pp. 13-14.

${ }^{3}$ For examples of materialist analyses of early modern women's writing, see Helen Smith, "Grossly Material Things": Women and Book Production in Early Modern England (Oxford: Oxford University Press, 2012); Gillian Wright, Producing Women's Poetry, 1600-1730 (Cambridge: Cambridge University Press, 2013); Patricia Pender and Rosalind Smith (eds.), Material Cultures of Early Modern Women's Writing (Basingstoke: Palgrave, 2014), and Julie Crawford, Mediatrix: Women, Politics and Literary Production in Early Modern England (Oxford: Oxford University Press, 2014).
} 
For many women from upper-class English families, translation formed part of educational activities that collectively emphasised and reinforced virtue and women's role within the household. Some girls learned foreign languages, customarily French, Italian, Latin and, more rarely, Greek, as part of noble households with a strong commitment to humanist learning. Girls who might become sovereigns were educated in much the same way as their male peers, through tutors who instructed them in continental and classical languages. In the sixteenth century, the diasporic communities of Protestant and Catholic exile during the reigns of Mary Tudor and Henry VIII also provided the opportunity for a new group of women from the middle classes to acquire additional languages and engage in translation, especially of religious texts. For women readers, whether proficient in languages other than English or not, the Bible was "the most important translated text of all": both translation, and authorised reading material, meant that it legitimated a range of translation activities on the part of women. ${ }^{4}$ These translations were forms of virtuous occupation for women, since theoretically the focus of the translator was on the source text.

However, in practice, the rich text of the Bible enabled experimentation, textual engagement, and production across a range of genres and with varying degrees of fidelity to the source. The formally inventive meditations on Psalm 51 that conclude Anne Lock's translation of John Calvin's sermons are a case in point; they combine the vernacular form of the English sonnet with psalm meditation to produce the first sonnet sequence circulated in England, in either print or manuscript form, in $1560 .^{5}$ Similar opportunities were afforded by paratextual and communal practices associated with studying the Bible, which saw women annotating their own religious texts,

\footnotetext{
${ }^{4}$ Clarke, The Politics, p. 173.

5 Anne Vaughan Lock, 'Meditation of a Penitent Sinner', in Susan Felch (ed.), The Collected Works of Anne Vaughan Lock (Tempe AZ: Arizona Center for Medieval and Renaissance Studies, 1999), pp. $62-71$.
} 
consulting commentaries and theological explanations, and participating in communal household prayers, discussions, and reading. Such informal networks, centered in the household but with broader communal effects, provided a context and a readership for the translation of works of theology. ${ }^{6}$ This is particularly true where families and kinship networks had commitments to particular theological and political positions, as with the translations under consideration here, emerging from the household of Sir Thomas More and the court of Henry VIII.

Despite the breadth and volume of early modern women's translation practice, however, and its centrality to women's active role in disseminating religious thought in the household and beyond, critics repeatedly note that early modern women's activity in this field is yet to be fully explored and documented. ${ }^{7}$ This perceived neglect may have arisen, in part, because translated texts complicate simple constructions of text and author-particularly problematic in a critical field once defined by the gender of the putative author and which, with the wider field, tends to privilege original authorship over other textual activities such as translation and imitation. Recent scholarship has drawn attention to the volume and importance of early modern women's translation; simultaneously it has begun to bring together different methodological approaches to confront these hierarchical and limiting models of text and authorship, repositioning translation as "a skilled, high-profile activity". ${ }^{8}$ In translation studies, old hierarchies of original versus translation and author versus translator have been replaced by models that view translating as

\footnotetext{
${ }^{6}$ See, for example, Micheline White, 'Women Writers and Religious and Literary Circles in the Elizabethan West Country: Anne Dowriche, Anne Lock Prowse, Anne Lock Moyle, Elizabeth Rous, and Ursula Fulford', Modern Philology, 103 (2005), pp. 187-214.

${ }^{7}$ Clarke, The Politics, p. 177; Micheline White, 'Introduction: Women, Religious Communities, Prose Genres and Textual Production', in Micheline White (ed.), English Women, Religion, and Textual Production, 1500-1625 (Aldershot: Ashgate, 2011), pp. 1-13, at pp. 7-8.

${ }^{8}$ Marie-Alice Belle, 'Locating Early Modern Women's Translations: Critical and Historiographical Issues', Renaissance and Reformation/Renaissance et Réforme 35 (2012), pp. 5-23, at p. 8.
} 
rewriting or collaboration, merging the roles of translator and writer, or have positioned translations in specific historical and cultural contexts to emphasise their complexity and contingency as a textual practice. ${ }^{9}$ This has significant ramifications for women's roles as translators, problematising arguments that link early modern women's authority to translate with a perceived secondary status associated with translation itself. Such arguments often cite John Florio's famous gendered metaphors in his preface to Montaigne's essays as their source: “all reputed femal[e]s, delivered at second hand". ${ }^{10}$ As Jaime Goodrich has recently shown in an extended analysis of Florio's other prefaces, the early modern view of translation was a more nuanced and complex one, alert to the ways in which knowledge and learning are sharpened, sweetened, and put to good service by their wide dissemination in translation. The role of the translator in these prefaces is not simply secondary but part of a project of plural authorship, where the translator takes on multiple metaphoric roles - all of which, Goodrich argues, "bears some authorial responsibility for the work itself". ${ }^{11}$

These developments in translation studies dovetail with a new interest in material cultures of textual transmission in the broader field of early modern literature. Alongside work highlighting the ways in which books are the product of multiple sources and processes, this scholarship draws attention to the ways in which that production is unstable and unfinished even at the point of originary publication. ${ }^{12}$

\footnotetext{
${ }^{9}$ Deborah Uman and Belen Bistué, 'Translation as Collaborative Authorship: Margaret Tyler's “The Mirrour of Princely Deedes and Knighthood”, Comparative Literature Studies, 44 (2007), pp. 298323; Susan Bassnet, 'When is a Translation Not a Translation?', in Susan Bassnet and André Lefevere (ed.), Constructing Cultures: Essays in Literary Translation (Clevedon: Multilingual Matters, 1998), pp. 25-40; André Lefevere, Translation, Rewriting and the Manipulation of Literary Fame (London and New York: Routledge, 1992), p. 8.

${ }^{10}$ Montaigne, Michel de, The essayes . . of Lord Michaell de Montaigne (London: Edward Blount, 1603), fol. $\mathrm{A} 2^{\mathrm{r}}$.

${ }^{11}$ Jaime Goodrich, Faithful Translators: Authorship, Gender, and Religion in Early Modern England (Evanston: North Western University Press, 2013), p. 5.

${ }^{12}$ See Donald F. McKenzie, 'The London Book Trade in 1644', in Peter D. McDonald and Michael F. Suarez (eds.), Making Meaning: "Printers of the Mind" and Other Essays (Amherst: University of Massachussets Press, 2002); Julian Yates, Error, Misuse, Failure: Object Lessons from the English
} 
Texts are most richly understood in broadly defined and intersecting contexts material, linguistic, social, and economic — and also in terms of extended publication histories, or the "publication event". Publication histories comprise an originary publication moment as well as the text's subsequent retransmission by different hands, at different moments and in different media. ${ }^{13}$ This approach encompasses the multiple ways in which early modern texts were performed, redacted, and retransmitted in oral, scribal, and print cultures across time, removing emphasis on originary, static, and single structures of publication and authorship in favour of a more broadly defined, process-oriented model of textual production. Such a shift is useful for both translation studies and studies of women's writing, as publication expands to include a range of literary activities surrounding a text: activities such as compilation, annotation, imitation, and translation. Gender also becomes a more contingent category — texts might be understood as “women's writing” in some publication contexts (when a text is circulated under a queen's patronage, for example, or translated by a woman) and not in others. ${ }^{14}$ This means that texts such as translations, where gender cannot always be securely located and interrogated, might demonstrate women's participation in literary cultures in new ways, alert to the shifting and extended material, generic, and social contexts through which texts are mediated.

Nonetheless, despite such promising developments in translation theory and in recent analyses of early modern women's translation, their intersection with similar critical moves in book history has not yet been fully explored. As Brenda Hosington

\footnotetext{
Renaissance (Minneapolis and London: University of Minnesota Press, 2003); Smith, “Grossly Material Things".

${ }^{13}$ Matt Cohen, The Networked Wilderness: Communicating in Early New England (Minneapolis: University of Minnesota Press, 2010), pp. 6-7.

${ }^{14}$ For the implications of this model for early modern women's writing, see Patricia Pender and Rosalind Smith, “Introduction: Early Modern Women's Material Texts: Production, Transmission and Reception", in Material Cultures, pp. 1-13, at pp. 1-5.
} 
argues in her recent introduction to a special issue on translation in Renaissance Studies,

The uneasy conjunction of instability and authority, confidence and anxiety, trust and mistrust that characterized the early print world manifests itself clearly in the plethora of translations that occupied the shelves of the early modern printers' and booksellers' shops. Given this shared experience and translation studies over the past few decades, it is surprising to say the least that these two areas of scholarship have until very recently remained resolutely separate. With regard to the early modern period, connections between them have been virtually non-existent, although translation and print were definitely linked in many minds at the time. ${ }^{15}$

The essays in Hosington's special issue go some way to beginning to merge these two fields, although none primarily address translations by women. In the following analysis of material surrounding three early Tudor religious translations by women, I build on recent work connecting material analyses, book history, and early modern women's writing. I do so by exploring how the multiple paratexts contained within these works form part of the works' particular publication events, and what the ensuing insights might mean for our understanding of early modern women as religious re-writers, as readers, and as agents within broader material and textual cultures.

\footnotetext{
${ }^{15}$ Brenda Hosington, 'Translation and Print Culture in Early Modern Europe', Renaissance Studies 29 (2015), pp. 5-18, at p. 10.
} 
The politics of paratext: Margaret More Roper's Devoute Treatise on the Pater

\section{Noster}

Much discussed in early modern women's translation studies, although not from a material perspective, are two religious translations circulated in print from the same familial milieu: Margaret More Roper's ca. 1525 translation of Erasmus's Devoute Treatise on the Pater Noster, and her daughter Mary Basset's 1557 translation of her grandfather Sir Thomas More's "Of the Sorrow of Christ", published as part of his Workes. ${ }^{16}$ Margaret More Roper was the eldest child of Thomas More, and knew Erasmus as a family friend; in 1523, Erasmus wrote a letter dedicating his Commentarius in duos hymnos Prudentii to her as a gift, addressing her as “castissimae puellae" — a most virtuous young woman. ${ }^{17}$ In a letter to More Roper's brother John a year later, Erasmus comments on the erudition of the three More daughters:

If one watched them flitting like honey bees through every sort of text in the two learned tongues - here jotting down a good phrase to reuse, there gathering some outstanding maxim on which to model their way of life, there learning some merry tale to be repeated to their companions - if you saw all this, you would say they were Muses at play in the flowery fields of Helicon. ${ }^{18}$

\footnotetext{
${ }^{16}$ Desiderius Erasmus, A deuoute treatise vpon the Pater noster (London: Thomas Berthelet, ca.1525); Mary Basset, 'De tristitia, tedio, pauore, et oration Christi ante captionem eius', in The Workes of Sir Thomas More, Knyght . . . written by him in the Englysh Tonge (London: John Cawood, John Waly and Richard Tottell, 1557), fols. QQ7 ${ }^{\mathrm{V}}-\mathrm{VV} 2^{\mathrm{V}}$.

${ }^{17}$ See Brenda Hosington, 'Translation in the Service of Politics and Religion: A Family Tradition for Thomas More, Margaret Roper and Mary Clarke Basset', in Jeanine de Landtsheer and Henk Nellen (eds.), Between Scylla and Charybdis: Learned Letter Writers Navigating the Reefs of Religious and Political Controversy in Early Modern Europe (Leiden: Brill, 2011), pp. 93-108, at pp. 99-100.

${ }^{18}$ Desiderius Erasmus, The Correspondence of Erasmus: Letters 1356-1534 (1523-1524), trans.

R. A. B. Mynors and Alexander Dalzell (Toronto: University of Toronto Press, 1992), p. 130.
} 
The publication of a translation of Erasmus in the mid 1520s was more, however, than, an act of sisterly companionship. As Jaime Goodrich has persuasively argued, Erasmus was widely viewed in early modern England as a source of quasi-Lutheran ideas since both he and Martin Luther condemned church abuses and promoted access to scripture in the vernacular. In 1524, when More Roper composed her translation, Erasmus was seeking to counter such an association, by widely circulating in the English court his public refutation of Luther in De libero arbitrio diatribe sive collatio (On the Freedom of Will). Even so, in the public mind his works remained linked with Luther's as a source of religiously innovation and heresy. ${ }^{19}$ In March 1526, a group of translations of Erasmus from the publisher Berthelet, which included More Roper's A Devout Treatise, was investigated by Richard Foxford for being works published without official approval from the council of bishops. ${ }^{20}$ Ironically, all of these works defended Erasmus as anti-Lutheran; nevertheless, they were caught up in a campaign to prevent the dissemination of Lutheran books in England.

When a second and licensed edition of More Roper's translation was published in 1526, Cardinal Wolsey's coat of arms was printed on the reverse of the title page: a prominent and authoritative marker of the English authorities' support for Erasmus and, more specifically, for More Roper's translation. None of Berthelet's other reissued publications includes this woodcut. The same image also implies a royal imprimatur by including, on the border surrounding the Wolsey coat of arms, the Tudor rose associated with Henry VIII, and the pomegranate associated with Catherine of Aragon. It might be noted that in 1525 Catherine of Aragon commissioned Erasmus to write a treatise on marriage, linking More Roper's translation with a royal, female promotion of his works. Brenda Hosington positions

\footnotetext{
${ }^{19}$ For a full account of the English association of Erasmus with heterodoxy, see Goodrich, Faithful Translators, pp. 37-39.

${ }^{20}$ Goodrich, Faithful Translators, p. 40.
} 
More Roper's translation in the "vanguard of a movement to spread Erasmus' brand of Christian humanism" through translation into English, one of over twenty editions and translations of Erasmian works published between 1520 and $1535 .^{21}$

Given the ways in which one section of the prefatory material of More Roper's A Devout Treatise? points to the work's circulation as a public and authorised text with a broader political purpose, it is surprising that critical analysis of the striking woodcut on the title page tells a conflicting story. This woodcut, which precedes the Wolsey coat of arms, represents a young woman at a lectern with a book open before her, her hands turning its leaves but her body and gaze angled to the left, away from her text. (Figure 1).

\section{[Place Fig. 26 here]}

[CAPTION for Fig. 26:] Erasmus, Desiderius, A deuoute treatise vpon the Pater noster, trans. Margaret Roper (London: Thomas Berthelet, ca. 1525), fol. A1r. By permission of the British Library, London.

Compared to Quentin Metsys's well-known portrait of Erasmus in his study, bent over his books and absorbed in writing his text, this perhaps unexpected orientation of the female subject means that the image has been consistently interpreted as one of private reading. Patricia Demers has noted the "interlocking, enfoliated tracery of the border, suggestive of a cloister" and implies that the female subject is overwhelmed and occluded: "shrouded by metres of cloth and almost surrounded by volumes a quarter or a third her size". ${ }^{22}$ Brenda Hosington notes that

\footnotetext{
${ }^{21}$ Brenda M. Hosington, 'Women Translators and the Early Printed Book', in Vincent Gillespie and Susan Powell (eds.), Companion to the Early Printed Book in Britain, 1476-1558 (Suffolk: Boydell and Brewer, 2014), pp. 248-271, at p. 256.

${ }^{22}$ Patricia Demers, Women's Writing in English: Early Modern England (Toronto: University of Toronto Press, 2005), p. 70.
} 
although "her hands are actively touching the pages . . . her averted gaze might well suggest she is contemplating what she has just read'; taken further by Goodrich, the woodcut on the titlepage represents "a woman apparently reading for her own benefit". ${ }^{23}$ As Hosington argues, this is at odds with Goodrich's detailed and convincing argument, outlined above, in favour of the political dimensions of the text as part of both a defence of Erasmus's reputation and a promotion of Catholicism based on humanist ideals. For Patricia Brace, the image has a complex ambivalence: it refers back to an ideal of female humanist education within households featured in previous uses of this woodcut, but in representing a real, rather than allegorical, female speaker, the image is truncated, her audience erased, and her speech implicitly silenced because of cultural tensions around "the danger of female speech". ${ }^{24}$ When paratext collides with the image of the female scholar, then, criticism reverts to models of femininity as isolated and constrained, with consequences for the extent to which More Roper's text can be viewed as politically engaged. It would seem that, at least with reference to the illustrated title page, the printer here worked against against the text's promotion of a female scholar's defence of Erasmian humanism. Yet I would like to suggest that the opposite might be the case, by tracing the material history of this image and its role across a number of previous publications.

The woodcut image of a female scholar on the title page of the 1526 edition was borrowed from the printer Wynkyn de Worde, cropped from a larger image and placed within a new border: it had previously been used in different forms in four books printed by or with a connection to de Worde between 1504 and 1512. As Brace argues, in four of these texts, the larger image was associated with rhetoric, and often

\footnotetext{
${ }^{23}$ Hosington, 'Women Translators', p. 253; Goodrich, Faithful Translators, p. 42.

${ }^{24}$ Patricia Brace, 'Speaking Pictures: Margaret Roper and the Representation of Lady Rhetoric', Moreana 50 (2013): pp. 93-130.
} 
included allegorical figures for female speech. ${ }^{25}$ The image first appeared in two texts by Stephen Hawes, The Example of Vertu and The Pastime of Pleasure. The earliest appearance of the image is in The Example of Vertu, first published in 1504 and reprinted in 1509 and 1530, where the female figure is represented at the lectern with an audience of three smaller figures, presumably children, whom she instructs and towards whom she diects her gaze. ${ }^{26}$ Two boys stand behind the lectern, their gazes directed to one another, and their stance and hand gestures suggesting that they are speaking to one another. A third figure (perhaps a girl as indicated by her partially covered hair), is seated in the foreground, taking notes. The image appears after a dream vision of a host of ten queens, including Minerva, Hecuba, and Juno, all "noble ladyes so pure and excellent/ Hardy in corage of age ryght tendre", who eventually surrender to death, in keeping with the conventional topos of worldly vanity. ${ }^{27}$ The woodcut also introduces a second narrative centered on the female dream guide "dame sapyence so full of blys", whose chamber is described as "so heuenly gloryfyed/ In vertue heale lyfe and salvacyon". ${ }^{28}$ Positioned between narratives of exemplary female political power and household virtue, the figure might be seen to represent both political acumen in the public sphere and ideal femininity in the private sphere.

The same image of a female figure reappears in another text by Hawes, The Pastime of Pleasure, published in four editions, 1509, 1517, 1554, and 1555, although the woodcut is included in only the 1509 and 1555 editions. In each of these two editions, the woodcut is reproduced three times. It first prefaces the speaker's account

\footnotetext{
${ }^{25}$ Brace, 'Speaking Pictures', pp. 93-96.

${ }^{26}$ Stephen Hawes, The Boke Called the Example of Vertu (London: Wynken de Worde, 1509), fol. Bb2v. Reproduced in Frank J. Sprang (ed.), The Works of Stephen Hawes (Delmar NY: Scholars' Facsimiles \& Reprints, 1975) from the copy in the Magdalene College Library, University of Cambridge.

${ }^{27}$ Hawes, The Example of Vertu, fol. $\mathrm{Bb}^{\mathrm{v}}$.

${ }^{28}$ Hawes, The Example of Vertu, fol. $\mathrm{B} 2{ }^{\mathrm{r}}$.
} 
of "the lady Gramer", who welcomes the speaker "into her godly studie"; it then divides narratives centred on women representing Rhetoryke and Logyke, and finally prefaces a taxonomy of the five parts into which rhetoric can be divided, introducing "the fyrste called inuencyon". ${ }^{29}$ In each appearance the function of the image is consistent: it serves as an example of female didacticism, to amplify and complement an argument for exemplary feminine learning, and to link in the reader's mind both the passages and the earlier text of The Example of Vertu. ${ }^{30}$

In the 1510 text Gospelles of Dystaues, also published by de Worde, the image again represents feminine learning, although its exemplarity is more problematic. Here the woodcut is specifically associated with "Dame Gonbarde the fare". 31 Described as a "doctoresse", daughter of a queen "by her moder syde", her claims as a "gentyllwoman" are immediately parodied by the description of her as a meddler in other's affairs and as sexually licentious: "yf some had had ony nede of a wensche/ she wolde haue done hym pleasure for gracious wyne". ${ }^{32}$ Yet Dame Gonbarde's speech is twice described as generating silence, and her "gospelle" consists of a collection of folk remedies, instructing her audience on practical methods to ensure a husband's love, train dogs, and husband cattle. ${ }^{33}$ The text is at once a parody of feminine learning and instructive of a different kind of feminine knowledge. As such, the woodcut image of a gentlewoman as teacher carries both a parodic and an exemplary charge.

\footnotetext{
${ }^{29}$ Stephen Hawes, The Pastime of Pleasure, ed. William Edward Mead (London: Early English Text Society, 1928), pp. 24-33.

${ }^{30}$ See Martha W. Driver, 'Ideas of Order: Wynkyn de Worde and the Title Page', in John Scattergood and Julia Boffey (eds.), Texts and Their Contexts: Papers from the Early Book Society (Portland, OR: Four Courts Press, 1997), pp. 87-149, at p. 93.

${ }^{31}$ Henry Watson, The Gospelles of Dystaues (London: Wynkyn de Worde, 1510), fol. D2r. Reproduced in Diane Bornstein (ed.), Distaves and Dames: Renaissance Treatises For and About Women (Delmar NY: Scholars' Facsimiles \& Reprints, 1978) from the copy in the Huntington Library, San Marino.

${ }^{32}$ Watson, The Gospelles of Dystaues, fol. D3 ${ }^{\mathrm{r}}$.

${ }^{33}$ Watson, The Gospelles of Dystaues, fol. $3^{\mathrm{r}}-\mathrm{D} 6^{\mathrm{v}}$.
} 
When this woodcut appeared as the title page to A Devout Treatise Upon the Pater Noster in 1526, it imported over twenty years of associations with exemplary and didactic female learning, largely virtuous. Yet in More Roper's treatise it is included in a very different form: cropped, an aleration which erases the domestic audience of children, and results in foregrounding the female figure. That is, rather than positioning her in a study, the cropping has the effect of presenting the figure primarily as scholar, at the lectern. For Brace, this means a foregrounding of her "solitary, receptive character", rendering the figure "legible neither as wife and mother nor as the analytical reader and articulate speaker who, for example, argues with her father in the Alington letter". ${ }^{34}$ I would like to suggest, however, that the truncating of an image so strongly associated in its previous iterations with female didacticism and power across a range of contexts has the opposite effect to illegibility. The figure's gaze is still directed outward, but beyond the frame of the text to a new, broad, and public audience: to the reader.

Recent scholarship has argued that the printers' use of woodcuts was specific and intentional — an interpretation that recuperates the role of de Worde in particular from careless mechanic to a strategically-minded producer of new books. ${ }^{35}$ Cropping and reframing the image imports previous textual associations of exemplary female didacticism to a new context. Simultaneously it remakes the woodcut into a representation that openly promotes the scholarship of its female subject. The title of the text reinforces this reading:

\footnotetext{
${ }^{34}$ Brace, 'Speaking Pictures', pp. 128-129.

${ }^{35}$ For the former view, see E. Gordon Duff, The Printers, Stationers and Bookbinders of Westminster and London from 1476 to 1535 (Cambridge: Cambridge University Press, 1906), p. 204; for revision see Seth Lerer, 'The Wiles of a Woodcut: Wynkyn de Worde and the Early Tudor Reader', Huntington Library Quarterly 59 (1996), pp. 381-403.
} 
A deuout treatise upon the Pater noster made fyrst in latyn by the moost famous doctor mayster Erasmus Roterodamus and tourned in to englisshe by a yong virtuous and well lerned gentylwoman of .xix. yere of age. ${ }^{36}$

Instead of positing a hierarchical, binary relationship between the Latin text and the translation, this wording outlines a publication event centred on the same text by two hands, "made fyrst into latyn . . . and tourned in to englisshe", in which both versions are afforded equal textual space. If Erasmus is the "moost famous doctor", then More Roper, I suggest, is equally privileged in this description, as "yong, virtuous and well lerned gentylwoman of .xix. yere of age". Considered together with the cropped woodcut, I would like to suggest that rather than an expression of a work that is “"private' and therefore appropriately feminine", we have here textual endorsement of the female humanist in her study in a parallel position to the male humanist whose work she reads and rewrites in translation. ${ }^{37}$

Such foregrounding of female translation as a parallel activity to Erasmus's composition of the text is continued in Richard Hyrde's framing dedication to "the moost studious and virtuous yonge mayde Fraunces S." (fol. A2 $2^{r}$ ). The dedicatee has been identified as Frances Staverton, Thomas More's niece and Margaret More Roper's cousin. Hyrde was a tutor in More's household, and his dedication is a spirited, sustained, and elegantly argued defence of women's scholarly education, specifically their instruction in Latin and Greek. In the dialogic tradition of the querelle des femmes, Hyrde puts forward and then counters the objections to women's classical instruction. For instance, the argument that women's mutable nature makes them more inclined to vice which is enflamed by classical texts is first refuted as the

\footnotetext{
${ }^{36}$ Desiderius Erasmus, $A$ deuoute treatise, fol. A1 ${ }^{\mathrm{r}}$.

${ }^{37}$ Goodrich, Faithful Translators, p. 44.
} 
result of unlearned men's envy. Subsequently it is countered through an argument that draws on classical precedent; Hyrde states that women are in fact "more upright and stedfast of mynde" than men, more conscious and ashamed of any fault than men, and more reasonable than men (fol. $\left.A 2^{v}\right)$. He proceeds to argue that learning has a more deleterious affect on men than women "because he can worse staye and refrayne himself than she", and because men have more opportunity to "utter such crafte as he hath gotten by his lernynge" since they are out in the world more than women-who "abyde moost at home/occupied euer with some good or necessary busynesse" (fol. $\left.A 3^{\mathrm{v}}\right)$. Indeed the value of reading in Latin and Greek, English and French is promoted as equally available to men and women, for the content and form "which euery good body bothe man and woman wyll rede and followe" (fol A3 ${ }^{\mathrm{v}}$ ). In this carefully established context of equality Hyrde then addresses the specific worth of reading for women: as an activity reading makes women less vulnerable to the "purposes" of corrupt priests and friars; it occupies the mind; it increases goodness in the virtuous. All this is an elaborate frame to introduce as the best exemplar of such virtuous learning "this gentylwoman whiche translated this lytell boke hereafter", "of whom other women may take example of prude[n]t, humble, and wyfely behauour, charitable \& very christe[n] vertue" (fol. A4 ${ }^{\mathrm{v}}$ ).

Hardly confined to the household, then, the translator's virtue is published as exemplary, a model to others of the program of humanist learning associated with the More family. Hyrde goes on to couple the translator's virtuous learning with that of her "vertuous, worshipfull, wyse and well lerned husbande". Indeed, their learning provides a mutual benefit_- “especiall conforte, pleasure and pastyme as were nat well possyble for one unlerned couple"-in an economy of reciprocity and equal gain rather than a gendered hierarchy (fol. B1). Overall Hyrde's discourse makes an 
example for Frances Staverton from her kinswoman, and the dedication concludes by briefly praising the skill of the translation itself: "erudite and elegant in eyther tong", and exemplifying "dyscrete and substancyall iudgement in expressynge lyuely the latyn" (fig. B2 ${ }^{\mathrm{v}}$ ). Nowhere does the text imply that its translator did not intend for it to be published, a common modesty trope, and Hyrde cites the translator's dislike of public praise only as a way of underlining her exemplary virtue. Framed in terms of male and female access to learning, endorsed by male and female royal emblems, foregrounding the image of the female humanist translator in her study, and circulated in three print editions in quick succession, More Roper's translation is exemplary: of early modern women's active, public, and humanist engagement with the dissemination of religious commentary in the 1520 s to audiences that might be framed as familial but which were in practice much broader.

\section{Paratext as material archive: Mary Roper Basset's De Tristia Christi}

To mention the breadth of audiences for More Roper's work is not to write out the relevance of religious translation for women within the household and within kinship circles: these texts could be simultaneously private, familial and public, available to a spectrum of uses and readers, and tailored to each through the ways in which a given text was circulated. This point revises an earlier critical tendency to see women's spiritual reading as only private, domesticated, and implicitly congruent with their subordination, in direct contrast to the kinds of active, goal-oriented and public reading attributed to men. ${ }^{38}$ Multiple scholars have recently argued for examples of early modern women's reading practices as "goal-directed" to varying extents, seeking "real world" effects in contexts that might include the household, the

\footnotetext{
${ }^{38}$ Lisa Jardine and Anthony Grafton, “'Studied for Action”: How Gabriel Harvey Read his Livy', Past and Present, 129 (1990), pp. 30-78.
} 
family, and broader social, religious, and political networks. ${ }^{39}$ Building on this work, the act of reading implicit in translation and foregrounded in a dedication such as Hyrde's provides a new context through which early modern women's book use might be understood. It broadens the way we might think of the range of practices associated with religious texts: not only did women read in silence in the practice of devotional meditation; they read for instruction and example, they annotated their texts with marginalia, and circulated that marginalia within coterie readerships or to print audiences — and they formalised their reading in forms such as translation, again circulated in manuscript and print. The material traces of book use indicate the variety of ways in which women used different types of books in their households: from the indentation of a nail, through marks on the page such as underlining, annotation and alteration of the text, to practices such as copying, rewriting and translating. In this sense, books and manuscripts could themselves constitute archives, containing complex collections of different texts added over time that allowed for a range of competing uses. ${ }^{40}$

Such a sense of the book itself as a material archive containing evidence of multiple reading practices, public and private, is highlighted through the following example of women's religious translation in the circles surrounding Sir Thomas More. Mary Roper Clarke Basset was Margaret Roper's daughter. She translated two texts: Eusebius's Ecclesiastical History into English and Latin (presented in manuscript to Mary Tudor), and a 1557 translation from Latin to English of her grandfather Thomas More's final Tower treatise, De Tristia Christi or Of the Sorowe of Christ, circulated in print within The Workes of Sir Thomas More Knyght. Printed

\footnotetext{
${ }^{39}$ See, for example, Julie Crawford, 'Reconsidering Early Modern Women's Reading, or, How Margaret Hoby Read Her de Mornay’, Huntington Library Quarterly, 73 (2010), pp. 193-223. ${ }^{40}$ William H. Sherman, Used Books: Marking Readers in Renaissance England (Philadelphia PA: University of Pennyslvania Press, 2008).
} 
by William Rastell, Basset's cousin, this massive folio of nearly fifteen hundred pages was an important part of an aggressive literary campaign by the More family to reclaim More's central status as a martyr within the Marian Counter-Reformation. In the 1550s, only More's secular works had been reprinted (A Dialogue of Comfort Against Tribulacion in 1553 and Utopia in 1556), and he was better known for his wit in his secular writing than his refusal to accept Henry VIII's separation from Rome, for which he was executed. ${ }^{41}$ Rastell's collection meant that More was the first English author after Geoffrey Chaucer to have his collected works issued in folio. The volume contains More's works in a chronological sequence that marks his increasing engagement with religious polemic as well as key events in his life, culminating in the texts produced in prison in the Tower of London. In effect, the material heft of the volume and the arrangement of its works combine to position More as a Catholic martyr. Just as importantly, they align the More family with Mary Tudor's key religious policies restoring the Catholic Church in England and eradicating heresy.

Unlike the other translations included in the compendium of the Workes, Basset's translation is prefaced by a separate introduction. Written by the printer Rastell, this addition repeatedly reinforces Basset's kinship to More. The title given to the translation presents the text "made in latine by sir Thomas More knight (whyle he was prisoner in the tower of London) and translated into englysshe, by maystres Marye Basset, one of the gentlewomen of the queenes maiesties priuie chaumber, and nece to the sayde syr Thomas More". ${ }^{42}$ Having confirmed Basset's status in the court, Rastell's preface to the reader twice describes the translator's exact relation to More, both as "a nere kinswoma[n] of his own", and as "daughter to William Roper esquyer and Margarete hys wife, daughter to the sayde syr Thomas More” (1350). This close

\footnotetext{
${ }^{41}$ Goodrich, Faithful Translators, p. 54.

${ }^{42}$ Thomas More, The workes of Sir Thomas More, p. 1350.
} 
familial connection is the means by which Basset's translation is explicitly authorised, in a translation that the preface presents as co-terminus with More's Latin precisely because it is performed by his kinswoman:

so sette oute in oure tongue, and goeth so nere sir Thomas Mores own english phrase that the gentlewoman (who for her pastyme translated it) is no nerer to hym in kynred, vertue and litterature, than in hys englishe tongue: so that it myghte seme to haue been by hys own pen indyted fyrst, and not at all translated: suche a gyft hath she to folowe her graundfathers vayne in wryting.

Often recruited to arguments for authorising Basset's female translation as subordinated to More's textual voice, this emphasis on kinship and alignment has quite another purpose in the context of a text circulated so as to promote the More family interests in the Marian court. It invests Basset as the new More, indicating her as his mirror in kinship, in virtue, in literature, and in her use of English, and investing her with the same facility in writing. Rather than erasing Basset, as a first reading might suggest, Rastell's preface promotes her voice and her family's project. This is done within much stricter confines than attended her mother's translation; the preface also contains the typical modesty trope of the translator's unwillingness to have her work published:

For yt ge[n]tlewoma[n] which tra[n]slated it, semed nothing willing to haue it goe abrode, for that (she sayth,) it was firste turned into englishe, but for her owne pastyme and exercyse, and so reputeth it farre to symple to come in many handes. 
As Trisha Pender has recently argued, such rhetoric of modesty cannot simply be read at face value; here it reinforces the preface's earlier characterisation of Basset's ideal virtue, a virtue that is explicitly recruited as a continuation of More's authority and influence through his descendants within the new context of the Marian court. ${ }^{43}$ Certainly, Basset's reluctance did not prevent publication of the translation. Further, the preface then speculates that the work might reach an even wider audience in a subsequent, independent publication "which mo would bye, set out alone" (p. 1350). Finally, the expression of reluctance regarding publication is not borne out by a third material aspect of this translation: the marginalia.

At a key point in Basset's translation, where she exhorts the necessity of prayer for the virtuous subject, she also inserts a marginal note explaining her deviation from the source texts. Following a passage explaining the benefit of prayer in the "dead darke time of night", the translation describes the restless halfwakefulness of poor sleep as a time when the soul is most in danger, especially when the subject falls "full fast a slepe, our minds all occupied wt mad fantasticall dremes" (p. 1375). Basset's printed marginal note directly comments on her choices as translator:

Whereas the latine texte hath here somnia speculantes Mandragore, I haue translated it in englishe, our mindes all occupied wyth mad fantasticall dreames, because $\mathrm{Ma}[\mathrm{n}]$ dragora is an herbe as phisycions saye, that causeth folke to slepe, and therin to have many mad fantastical dreames. (p. 1375)

\footnotetext{
${ }^{43}$ Patricia Pender, Early Modern Women and the Rhetoric of Modesty (Basingstoke: Palgrave Macmillan, 2012), pp. 1-7.
} 
The reader does not have access to the source text. Hence this marginal note works less to clarify a deviation than to promote the translator's facility with Latin and with medical knowledge. More importantly, however, it also contradicts Rastell's argument in the preface, indicating that Basset's voice as translator is not identical to More's - thereby effectively highlighting the creativity of her translation practice. The printer's inclusion of this note foregrounds Basset as learned reader and innovative rewriter, speaking through the authority of her kinship to More, but in her own voice. Later in the text, Basset's marginalia signal further editorial interventions, aligned with the preface's positioning of More as a martyr who was forced to put aside his books before execution:

I haue not translated this place as the latine copye goeth, but as I iudge it shoulde be, because my grandfathers copy was for lacke of laysure neuer wel corrected. (p. 1399)

Here the translator reverses the order of a sentence for clarity, placing its biblical quotation at the front of the sentence. On the same page, she interpolates a phrase where the text refers to "his prophecie" without providing one:

This prophecie ... was not writen in my graundfathers copye, \& therfore I do geasse that this or some other like he woulde hymselfe haue written. (p. 1399)

Both marginal notes stress Basset's familial relationship to the author of the source text, as a way of creating trust in the reader's mind that these changes are aligned with the original. But they also highlight Basset's agency as reader and translator. This 
element is especially striking since the other marginal notes in this folio serve to summarise passages or to point out allusions, and do not highlight the translator's intervention.

The presence of Basset's notes parallels other extra-authorial practices she undertook, such as her funding and production of the anonymous Latin Chronicle of Henry VIII's first divorce. The preface to this work claims that the chronicle was printed "with the help and at the cost of a most noble and at the same time most learned woman, a granddaughter of Thomas More by his daughter". ${ }^{44}$ Therefore Rastell's preface to Basset's translation in the Workes of Sir Thomas More Knyght needs to be read in a broader material context; one that identifies the printer's diminution of Basset's role in publishing More's works as a rhetorical constructrather than a historical fact. Conflicting constructions of Basset as private reader and writer of a familial text, as privileged insider in the Marian court, as creative and authoritative translator, and as the More family's representative within the Marian court co-exist in the complex archival economy of the Workes. These overlapping positions indicate a spectrum of textual practices and identifications available for deployment within a text that was circulated by the More family for goal-oriented political action in the form of familial, religious, and political gain.

\section{Translation in the margins: Mary Tudor's "Concede mihi, misericors Deus"}

The published work of Basset shows printed marginalia as one example of the complex ways in which early modern women used their books. Scribal marginalia, especially with reference to early modern women's translation practice, demonstrate another way in which material cultures of early modern book use can provide new

\footnotetext{
${ }^{44}$ Goodrich, Faithful Translators, p. 58.
} 
perspectives on women's textual practice. My example here shifts focus from the circles of the More family to the households and court of Mary Tudor. The princess' most well-known translation is of Erasmus's explication of John, translated from Latin to English as part of Katherine Parr's project to translate Erasmus's Paraphrases on the New Testament, begun by September 1545. Although Mary eventually abandoned the project for her chaplain, Francis Mallet, to finish, this was an ambitious, rhetorically skilful, and widely circulated example of translation which had enormous impact. The royal requirement that the Paraphrases be kept in every parish church in England meant that between twenty and thirty thousand copies of the work were printed, each including a translation explicitly attributed, in part, to Mary. $^{45}$

At the opposite end of this wide spectrum of circulation is Mary's earlier translation of "Concede mihi, misericors Deus", the prayer for ordering life wisely written by Thomas Aquinas. This translation was copied and attributed to Mary in the concluding leaves of a manuscript book of hours belonging to Mary Wotton, Lady Guildford, one of Catherine of Aragon's ladies-in-waiting. ${ }^{46}$ Thus it was circulated in far fewer than thousands of copies. Yet the fact that it was included in the book of hours indicates that it had some contemporary courtly circulation. Additionally, the manuscript contains a collection of signatures and other marginalia-written in fifteen distinct hands - which demonstrates that the book was shown to others within the court. There is also evidence of the translation's later circulation; in the 1530s it was

\footnotetext{
${ }^{45}$ Aysha Pollnitz, Princely Education in Early Modern Britain (Cambridge: Cambridge University Press, 2015), p. 239.

${ }^{46}$ London, British Library, Additional MS. 17012, fols. $192^{\mathrm{v}}-194^{\mathrm{r}}$. On this book of hours see also Eamon Duffy, Marking the Hours: English People and their Prayers, 1240-1570 (New Haven, CO: Yale University Press, 2006), pp. 156-157.
} 
copied into books belonging to the wife and children of Henry Parker, Lord Morley, to "gyve them occasion to temember to praye for your grace". 47

The comparatively restricted nature of the poem's circulation is not necessarily an indicator of its political ambition or effect. In the manuscript book of hours the translation is copied in two hands, introduced on folio $192 \mathrm{v}$ as "the prayer of Sainte Thomas of Aquyne translatyd oute of latine unto Englysshe by $\mathrm{y}^{\mathrm{t}}$ moste exselent [--n--] Mary doughter to the most hygh and myghty Prynce and Prynces kyng Henry the Viii and [----- ---- ---- ----] In the yere of oure lorde god iy. ccccc. xx vii: And the xi. yere of here age". This prefatory material establishes the princess' learning - "translatyd oute of latine unto Englysshe"; her royal status (although her title of "Prynces" and that of her mother Quene Kateryn is vigorously crossed out by a later reader), and her precocious age. If this formal introduction is not sufficient, Mary adds her own comment on the prayer in a short, unlineated lyric in the bottom margin (lineated here):

I haue sed that nobody lyuethe as he shulde doo but he that foloueth vertu and I rekenyng you to be on of them I pray you to remembre me yn your deuocyons

Marie [---- ----]

Mary's addition of marginalia in her own hand to a prayer that is itself a marginal addition to the book of hours serves multiple functions. Like the print

\footnotetext{
${ }^{47}$ Jaime Goodrich, "Mary Tudor, Lord Morley and St Thomas Aquinas: The Politics of Pious Translation at the Henrician Court", ANQ: A Quarterly Journal of Short Articles, Notes and Reviews 24.1-2 (2011), 11-20, at 17.
} 
marginalia that accompany Mary Basset's translation, Mary Tudor's annotation serves as an insistent reminder to the reader of the princess's textual agency as translator, beginning with her claim that her translation is in her own words: "I haue sed". Rather than merging her voice with that of Aquinas, she takes ownership of the translation, and of its message "that nobody lyuethe as he shulde doo but he that foloueth vertu". Aquinas's prayer as translated by Mary exceeds this gloss, however. It offers a program by which the devout subject simultaneously follows a virtuous path and relinquishes the self to God's direction, calling for their experience to be ordered absolutely by God: "Order my lyuyng that I may do that whiche thou requrest of me . and geue me grace that I may know yt and haue Wyll and power to do it and that I may obtayne those thingis . Whiche be moste conuenient for my sowle:" (fol. $192^{v}$ ). This relinquishment includes a composed and equitable response to both "prosperite" and "aduersyte", good and bad fortune, that sees the subject affected by neither:

I be not

lyfte $v p w^{t}$ the oon nor oppressid with thother and that I may reioyse yn no thing but in this whiche movith me to the nor be sory for nothing but for those whiche drawith me frome the Desiring to please no body nor fering to displese anny besidis the : Lorde let all worldly thingis be vile to me for the. and that all thi thingis be dere to me . (fol. 193 ${ }^{\mathrm{r}}$ ) 
Buried in this passage is a declaration of independence from any control other than God's, "Desiring to please no body nor fering to displese anny besidis the". The year in which this translation was added to the book of hours was the year in which Mary's father, Henry VIII, began to circulate his intentions to divorce her mother, Catherine of Aragon, both within the court and more widely. As Jaime Goodrich suggests, the prayer translation might be read as an initial response to such an adverse event in Mary's life, providing a program for weathering the inevitable storms through a focus on God rather than the world. ${ }^{48}$ Indeed, the final sections of the prayer translation provide a set of clear and concise instructions for living:

aye god make me humble with oute fayning . mery $w^{t}$ oute lyghtines Sade $w^{t}$ oute mystruste sobir $w^{t}$ oute dulnes Fearing $w^{t}$ oute dyspacanon Gentill woute doblenes Trusting in the $\mathrm{w}^{\mathrm{t}}$ oute presumpcyon Telling my neybors fawtis $w^{t}$ oute mokking Obe dyent $w^{t}$ oute arguyng Pacient $w^{t}$ oute grutching And pure $w^{\mathrm{t}}$ out corrupcion (fol. 193v

Delivering the subject to heaven's “Joies and rewardys", this set of directives for the devout subject amounts to a statement of the subject's orientation not to family nor

\footnotetext{
${ }^{48}$ Jaime Goodrich, 'Mary Tudor, Lord Morley, and St. Thomas Aquinas: The Politics of Pious Translation at the Henrician Court', ANQ 24 (2011), pp. 11-20.
} 
state but to God, an orientation that the scribal marginalia appending the first page of this poem underscores and frames.

Mary Tudor's short lyric inscribed in the bottom margin is surprisingly complex in the way it directs the reader's attention. ${ }^{49}$ It opens with a statement of selfassertion - "I haue sed"- and with a statement of lack in others, that "nobody lyuethe as he shulde doo". Doctrinally orthodox, this statement contains a subtext of criticism for the reader of the translation, general or specific. Only then does the poem introduce the exception — "but he that foloueth vertu" - which offers a model of living located in the prayer as reworded and published by the princess. This model of living is also one of virtue, and one insistently grounded in the rejection of worldly vanity and secular power. After this politically pointed opening, circulated in a climate where it is widely known that the king is seeking divorce so as to pursue his own secular interests, the poem moves to flattery of the now single reader to which it is addressed: "and I rekenyng you to be on of them". The grammar here is ambiguous: two options are presented in the preceding lines: those who do not live as they should, and the exceptions who follow virtue. Logically, in terms of politics and of friendship, the lyric should identify its reader as the second, but an ambiguity remains, located again in the speaker's own "reckyning". Admonition, instruction, and deliberation turn finally to the poem's fourth move, a conventional claim for remembrance of the "I" who speaks, directs and judges: "I pray you to remembre me yn your deuocyons".

This marginal lyric is, I suggest, distinct from conventional marginalia intended to promote the reader's remembrance of the subject in their prayers. It insists on the relationship of friendship between the princess and the lady-in-waiting to the queen, while also seeking to direct the latter's reading towards the princess's own

\footnotetext{
${ }^{49}$ There is some evidence of the translation's broader manuscript circulation beyond the royal family, copied into books belonging to the wife and children of Morley in order to "gyve them occasion to temember to praye for your grace”. See Goodrich, 'Mary Tudor, Lord Morley', p. 17.
} 
translation. It orients the coterie reader towards God rather than the world, and directs others to follow the princess' example by chosing the same path. These differences are amplified by the marginal poem's presence in this particular book of hours, which, after the conclusion of its opening prayer, contains two leaves featuring a collection of similar royal requests for remembrance. Folio 20v contains the signature of Henry VIII, as well as a request for remembrance from Mary Tudor's mother, Catherine of Aragon:

I thinke the prayrs of a frend be most acceptable vnto god and because I take you for one of myn assured I pray you you ${ }^{\text {to }}$ remembre me in yours

katherin [------] (fol. 20v $)$

On the facing page is a matching lyric by Henry VII, and another by Elizabeth of York:

Madame I pray you Re membre me / your louyng maister henry R

Madam I pray you forget 
[---] me to pray to god

that I may haue part of

your prayers

Elysabeth $y^{t}$ queen (fol. $21^{r}$ )

This succession of inscriptions means that Mary Tudor's poem asking for remembrance forms part of a compendia of such lyric requests by kings and queens: it marks her relationship with her father, and her royal claims to the throne. Appending a translation that offers strategies for resistance to secular power as well as implicit criticism of those that do not follow God's way, it constitutes a bold assertion of Mary's position as the next Tudor sovereign and, implicitly, the legitimacy of her mother's marriage to Henry VIII. This superficially simple lyric is politically charged, negotiating the complex discourses of resistance, instruction, and careful courtly selfpositioning in a climate of personal, political, and religious danger to the princess. Sadly, the book of hours also records the same strategy's lack of success, in the subsequent erasure of the titles of Queen Catherine and Mary, and of Catherine's name in the preface to her daughter's translation. In 1526, however, this translation and its framing marginal lyric indicates that such an outcome might still have been considered open to negotiation and intervention, even by an eleven-year-old princess, who used the roles and modes of manuscript circulation at her disposal to assert an exemplary pursuit of virtue. 
All three of the early Tudor translations by women discussed in this essay are materially positioned not as a subordinate activity, but as a kind of co-labour within publication events extending across multiple hands and textual instantations. In relations more complex than "original to copy" or "first to second", when a text is "made first" in one language, it is "then turned" into another, creating versions of the same text produced over time and altered according to contexts of recirculation. Further, the paratextual material surrounding these translations presents women as engaged with the dissemination of particular religious positions in overlapping familial, social, and political spheres: these paratexts can involve invocations of the role and self-image of the female translator as private and faithful to the source text at the same time as they recruit such identifications to the public promotion of dynastic and religious interests in the royal court. Attention to the multiple sources of paratextual material within early modern printed books, such as woodcuts, prefaces, and marginalia, gives us a richer sense of the complexity of roles a female translator might adopt or be positioned as, even within a single text. These roles include those of reader and writer, virtuous mother, daughter, subject and friend, as well as scholar, humanist, and religious activist. In the archival economies contained within these texts, and across their multiple instances as publication events, women's translations are framed in surprisingly complex and political terms. Their diverse paratexts, especially when read in concert, provide the clues the reader needs to understand Tudor women's translations as significant literary and political interventions, directed beyond the household to a broad range of readers. 


\title{
CHAPTER 9
}

\section{Translating Eloquence: History, Fidelity, and Creativity in the Fairy Tales of Marie-Jeanne Lhéritier}

\section{Bronwyn Reddan}

\begin{abstract}
After these words, the king recited a story to Blondel, of which I will recount all the content and the substance. But I will retain neither the same words nor any excessively long narration. I believe, however, that I am permitted to add a few reflections, but at the same time I will remove certain circumstances that would not be to the taste of our century. It is not therefore King Richard who speaks, it is me. ${ }^{1}$
\end{abstract}

With these lines, Marie-Jeanne Lhéritier de Villandon declares that her fairy tales recount historical sources which she has modified for her audience. Her open declaration illustrates the complex strategies of self-representation used by early modern women writers. Educated in ancient and modern history and literature by her father, Nicholas Lhéritier, who was royal historiographer to Louis XIV, Lhéritier published fairy tales in two heterogeneous collections of prose and verse works: Euvres meslées (Mixed works) in 1696, and La Tour ténébreuse et

\footnotetext{
1 “Après ces mots, le roi récita à Blondel un conte, dont je vais rapporter tout le fond et la substance ; mais je ne conserverai pas les termes ni les narrations trop étendues ; je me croirai cependant permis d'y ajouter quelques petites réflexions ; mais en même temps j'en retrancherai diverses circonstances, qui ne seraient pas de goût de notre siècle, ce n'est donc pas le roi Richard qui parle, c'est moi”: Marie-Jeanne Lhéritier, La Tour ténébreuse et les jours lumineux, in Raymonde Robert (ed.), Contes: Mademoiselle Lhéritier, Mademoiselle Bernard, Mademoiselle de La Force, Madame Durand, Madame d'Auneuil (Paris: Honoré Champion, 2005), p. 138. Unless stated otherwise all translations are by Bronwyn Reddan, and all citations to Lhéritier's tales are to this edition.
} 
les jours lumineux (The dark tower and luminous days) in $1705 .^{2}$ Lhéritier framed her tales with metatextual and paratextual commentary that emphasised their medieval and oral origins. This commentary appears in Lhéritier's interpolation of her voice in the narrative of her tales, and in dedications addressed to women - including fellow author Henriette-Julie de Castelnau, Comtesse de Murat and the (fictional) daughter of Charles Perrault. ${ }^{3}$ Lhéritier dedicated the three tales in Cuvres meslées, Marmoisan ou L'Innocente Tromperie, Les Enchantements de l'Éloquence ou les effets de la douceur, and L'Adroite Princesse ou Les Aventures de Finette to Mademoiselle Perrault, Madame la Duchesse d'Epernon and Madame la Comtesse de Murat respectively. La Tour ténébreuse, and the two tales embedded in it, Ricdin-Ricdon and La robe de sincérité, are dedicated to Madame la Duchesse de Nemours. In her Lettre à Madame D.G** in Cuvres meslées, Lhéritier developed a theory of the fairy tale genre that defended the literary creativity of the women writers involved in its creation. The rhetorical strategies Lhéritier used to frame her tales emphasise her scholarly credentials as a writer, translator, and critic. In representing herself as a historian and her tales as translations of historical sources, Lhéritier constructs her authorial identity as a faithful storyteller who recounts tales she has discovered rather than invented. Yet in recounting these tales for a modern literary audience, Lhéritier engages in multiple acts of translation:

\footnotetext{
${ }^{2} 1696$ is the official date of publication for Euvres meslées but it is likely that the manuscript was printed in 1695: Ruth Bottigheimer and Sophie Raynard, 'Marie-Jeanne Lhéritier de Villandon, “Diverse Works” (1696)', in Fairy Tales Framed: Early Forewords, Afterwords, and Critical Words (Albany: State University of New York Press, 2012), pp. 127-154, at pp. 127-129.

${ }^{3}$ Lhéritier's dedication is the only documentary reference to the existence of Mademoiselle Perrault: Yvette Saupé and Jean-Pierre Collinet, 'Charles Perrault: 1628-1703', in Sophie Raynard (ed.), The Teller's Tale: Lives of the Classic Fairy Tale Writers (New York: SUNY Press, 2012), pp. 47-59. Bottigheimer and Raynard suggest that Lhéritier ironically invented a fictional sibling for the son Perrault claimed was the author of his Histoires ou Contes du temps passé: 'Marie-Jeanne Lhéritier de Villandon', pp. 130-131.
} 
transforming their genre from oral stories to literary texts, and transporting stories from the medieval past to her modern present. ${ }^{4}$

Lhéritier's contribution to the development of the fairy tale genre is one of several literary achievements. Born in Paris in 1664 to Nicholas Lhéritier and Françoise Le Clerc (who was either the sister or niece of the mother of Charles Perrault), Lhéritier became a celebrated woman of letters who produced a diverse literary oeuvre. In addition to three collections of writing, Euvres meslées, La Tour ténébreuse, and Les Caprices du destin (1717), Lhéritier published several prose and verse works in the modern literary periodical Le Mercure galant. ${ }^{5}$ In 1703, Lhéritier produced three editions of her own periodical, L'Érudition enjouée. She also edited the memoirs of the Duchesse de Nemours, one of her patrons, in 1709, and composed panegyrics celebrating the lives of Madeleine de Scudéry and Antoinette Deshoulières. The latter two works, which were published in 1694 and 1702 respectively, praise the work of Scudéry and Deshoulières, as well as other French women writers including Marie de France and Christine de Pizan. Lhéritier's final published work was a 1932 translation of Ovid's Heroides. ${ }^{6}$ Lhéritier was admitted as a member of the Académie des Lanternistes in Toulouse in 1696; she won prizes from this academy, and from

\footnotetext{
4 'Transporting' is used in this chapter in a figurative sense to refer to both the movement of stories across time and the affective impact of reading a story that allows one to feel transported to another time or place.

${ }^{5}$ See e.g. Le Mercure Galant (April 1697): pp. 203-208; (October 1699): pp. 141-143; (February 1700): pp. 65-73; (June 1700): pp. 235-236; (July 1700): p. 109; (September 1700): pp. 159-169; (November 1700): pp. 142-146; (January 1701): pp. 387-388; (March 1701): p. 166; (June 1701): pp. 137-148; (May 1702): pp. 4249; (September 1702): p. 132.
${ }^{6}$ The titles and publication details of Lhéritier's works are listed at the end of this chapter and in the bibliography.


the Académie des Palinots in Caen. In 1697, Lhéritier was awarded honorary membership of the Accademia dei Ricovrati of Padua. ${ }^{7}$

Lhéritier's contemporary reputation as a scholar and theoretician is emphasised by eulogies published by Le Mercure galant and Journal des sçavans in 1734. Both journals celebrated Lhéritier's literary achievements and recognised her position within a network of women readers and writers. The focal point of this network was the Parisian salons of the late seventeenth and early eighteenth centuries, in particular the twice-weekly salon Lhéritier is said to have inherited from Scudéry. ${ }^{8}$ Lhéritier's position within this socio-literary network of salon writers locates her work in the "textually mediated social field" that Allison Stedman identifies as a key factor in transformation of the mode of French literary production in the second half of the seventeenth century. ${ }^{9}$ The metatextual and paratextual framing of Lhéritier's fairy tales reflects the shift away from the oral-collective mode of salon literary production; her heterogeneous collections of writing helped to transform the sociable practice of salon conversation from an activity located in the physical space of the salon to a literary aesthetic designed to entertain a circle of female readers. Lhéritier's framing of her fairy tales translated the orality of salon storytelling into individual acts of creativity mediated by the exchange of written texts. ${ }^{10}$

\footnotetext{
7 'Eloge de Mademoiselle l'Héritier', Journal des Sçavans (1734), pp. 832-836. See also Nadine Jasmin, 'Sophistication and Modernization of the Fairy Tale: 1690-1709', in Sophie Raynard (ed.), The Teller's Tale: Lives of the Classic Fairy Tale Writers (New York: SUNY Press, 2012), pp. 41-46, at p. 44.

8 'Eloge de Mademoiselle l'Héritier', p. 836.

${ }^{9}$ This phrase appears several times in Allison Stedman, Rococo Fiction in France, 1600-1715: Seditious

Frivolity (Lewsiburg: Buckness University Press, 2013), especially at pp. 82-113.

${ }^{10}$ Stedman, Rococo Fiction in France, pp. 138-46.
} 
Despite her contribution to the theorisation of the genre now broadly defined as the literary fairy tale, Lhéritier does not refer to any of the tales in Euvres meslées and La Tour ténébreuse as contes de fées. Marie-Catherine le Jumel de Barneville, Comtesse d'Aulnoy was the first author to use this term in the title of her 1697 collection of tales, Les Contes des Fées. The literal English translation of contes de fées is "tales of fairies" or "tales about fairies"; the term "fairy tale" was not commonly used in English until the mid-eighteenth century. ${ }^{11}$ In Cuvres meslées, which predated d'Aulnoy's Les Contes des Fées, Lhéritier describes her tales as nouvelles (novellas), contes (tales), and fables (fables). In the same volume, Lhéritier's letter to Madame D.G** also refers to these tales as petites histoires (little stories), récits (narratives), and contes merveilleux (marvellous tales). ${ }^{12}$ Such terminological fluidity reflects the emerging nature of the genre rather than an attempt to establish strict generic boundaries. The first French literary fairy tale was published by d'Aulnoy as a story interpolated into a novel in 1690, and Lhéritier's 1696 Euvres meslées was the first published collection of stand-alone tales. The popularity of the nascent genre exploded in the second half of the 1690s, with a large number of tales published in 1697 and 1698. In total, more than one hundred fairy tales were published by French authors between 1690 and 1709 . Two-thirds of this corpus were produced by women writers including d'Aulnoy, Lhéritier,

\footnotetext{
${ }^{11}$ Jack Zipes, 'The Meaning of Fairy Tale within the Evolution of Culture', Marvels \& Tales, 25 (2011), pp. 221-243, at pp. 222-223. The first English translation of d'Aulnoy's Les Contes des Fées was published under the title Tales of the Fairies in 1707: Gabrielle Verdier, 'De Ma Mère L'Oye à Mother Goose: La fortune des contes de fées littéraires français en Angleterre', in Contacts culturels et échanges linguistiques au XVIIe siècle en France (Tübingen: Papers on French Seventeenth Century Literature, 1997), pp. 185-202.

${ }^{12}$ For a discussion of the meaning of this terminology see Ruth Bottigheimer and Sophie Raynard, 'Fairy Tales and Fairyland Fictions in France', in Fairy Tales Framed: Early Forewords, Afterwords, and Critical Words (Albany: State University of New York Press, 2012), pp. 101-111, at pp. 103-108.
} 
and Murat. ${ }^{13}$ Their tales inaugurated key features of the fairy tale genre, such as the marriage closure. The term fairy tale is used in the present chapter since it best reflects the nature of the genre developed by Lhéritier and her contemporaries. ${ }^{14}$

This chapter analyses Lhéritier's use of the rhetoric of translation to frame her fairy tales as modern versions of medieval troubadour tales. The first section examines the relationship between fidelity and creativity in early modern theories of translation. The second section analyses Lhéritier's self-representation as a historian and storyteller who wrote to educate and entertain her modern audience.

\section{Fidelity, Creativity, and Translation in Early Modern France}

I employed much application and care to follow the sense of my author. . . Except that I have toned it down slightly in places where good taste would have been offended, I have always followed it with great exactness. ${ }^{15}$

Like many of her early modern contemporaries, Lhéritier used the paratexts framing her work to define her identity as a writer and translator. The rhetorical strategies of self-representation in her paratexts, such as the above quotation from her translation of Ovid's Heroides, identify

\footnotetext{
${ }^{13}$ Raymonde Robert, Le conte de fées littéraire en France: De la fin du XVIIe à la fin du XVIIIe siècle (Paris: Champion, 2002), pp. 75-82 and 311-328.

${ }^{14}$ Compare Bottigheimer and Raynard, who distinguish between fairy tales and fairyland fictions as different genres of marvelous tales: 'Fairy Tales and Fairyland Fictions in France', pp. 101-111.

15 “J'ai apporté tant d'application et de soins à bien suivre le sens de mon Auteur. ... Excepté, que je l'ai un peu adouci dans les endroits où les bienséances auraient pu être blessées, je l'ai toujours suivi avec une grande exactitude": Les épîtres hérö̈ques d'Ovide, traduites en vers françois, par Mlle L'Héritier (Paris: Brunet, 1732), ix. Here I have modernised the spelling of quotations from this preface.
} 
her as an author who "use[d] translation to think". ${ }^{16}$ The avertissement to this translation follows a dedicatory letter addressed to Marie Magdeleine Angélique de La Brousse, la Comtesse de Verteillac. It identifies Lhéritier's motive in commencing the translation as a desire to "obey two women as distinguished by their merit as by their birth". ${ }^{17}$ Joan DeJean identifies these women as Anne Le Fèvre Dacier and Madeleine de Scudéry, and suggests that Lhéritier's translation was influenced by their portraits of Sappho. ${ }^{18}$ Dacier published a prose translation of Sappho in 1681, Les poësies d'Anacreon et de Sapho. Scudéry, who was referred to as "Sapho" by literary contemporaries, published her version of the romance of Sappho and Phaon in Artamène, ou le Grand Cyrus (1648-53). Along with her decision to translate a text comprised of letters that offer a female perspective on events in classical mythology, Lhéritier's oblique reference to Dacier and Scudéry locates her translation firmly within a tradition of female literary production — and pays homage to the voice of women writers.

Further, Lhéritier's acknowledgement that she has tempered her fidelity to Ovid's text with regard to seventeenth-century standards of decorum provides insight into a key aspect of her approach to translation. Her remodelling of Ovid as a galant poet fluent in the language of salon conversation emphasises the creativity of translation as a process of reinvention. ${ }^{19}$

\footnotetext{
${ }^{16}$ Tania Demetriou and Rowan Tomlinson, 'Introduction: “Abroad in Mens Hands”: The Culture of Translation in Early Modern England and France”, in Rowan Tomlinson and Tania Demetriou (eds.), The Culture of Translation in Early Modern England and France, 1500-1660 (Basingstoke: Palgrave Macmillan, 2015), pp. 121 , at 16 .

17 “pour obéir à deux Dames aussi distinguées pas leur mérite que par leur rang”: Les épîtres hérö̈ques d'Ovide, pp. viii-ix.

${ }^{18}$ Joan DeJean, Fictions of Sappho, 1546-1937 (Chicago: University of Chicago Press, 1989), p. 114.

${ }^{19}$ DeJean argues that Lhéritier's translation is the "culmination" of this eighteenth-century process of remodelling: Fictions of Sappho, p. 130.
} 
Lhéritier's standard of exactness is not designed to produce a literal translation of Ovid's Latin; nevertheless she claims to be faithful to the essence or sense of Ovid's thoughts. ${ }^{20}$ This fluid notion of fidelity corresponds to Annie Cointre's observation of fluctuation in the meaning of fidelity in translators' prefaces to seventeenth-century French prose narratives. In this context, "fidelity to the original" referred to preservation of the esprit or spirit of a text that had been submitted to French norms, as well as literal approaches to translation. ${ }^{21}$

The relationship between fidelity and creativity was an ongoing source of tension in early modern discourse about translation. The long-standing distinction between traduction littérale (literal, or word for word, translation), and traduction libre (a dynamic or free approach to translation also known as belle infidèle), is the most striking example. ${ }^{22} \mathrm{~A}$ tension between freedom and fidelity was also manifested in a number of other debates that shaped the cultures of translation in early modern France. ${ }^{23}$ Yen-Maï Tran-Gervat and

\footnotetext{
${ }^{20}$ Les épîtres hérö̈ques d'Ovide, p. ix.

${ }^{21}$ Annie Cointre, 'Prose Narrative', in Yves Chevrel, Annie Cointre, and Yen-Maï Tran-Gervat (eds.), Histoire des traductions en langue française, XVIIe et XVIIIe siècles: 1610-1815 (Lagrasse: Verdier, 2014), pp. 11211209, especially pp. $1170-1177$.

${ }^{22}$ Yen-Maï Tran-Gervat, 'Penser la Traduction', in Histoire des traductions en langue française, pp. 369-432, especially at pp. 379-386. Glyn P. Norton identifies literal and creative approaches as influences shaping Renaissance practices of translation: The Ideology and Language of Translation in Renaissance France and Their Humanist Antecedents (Genève: Droz, 1984), pp. 10-17.

${ }^{23}$ The term "cultures of translation" reflects a shift in translation scholarship away from comparisons of source and target texts to examination of the nexus of actors and social relationships involved in the collaborative production and circulation of early modern texts: see e.g. Peter Burke: 'Cultures of Translation in Early Modern Europe', in Peter Burke and R. Po-Chia Hsia (eds.), Cultural Translation in Early Modern Europe (Cambridge: Cambridge University Press, 2007), pp. 7-38; Georges L. Bastin and Paul F. Bandia, Charting the Future of Translation History (Ottawa: University of Ottawa Press, 2006); Belén Bistué, Collaborative Translation and Multi-Version Texts in Early Modern Europe (Burlington, VT: Ashgate, 2013).
} 
Frédéric Weinmann identify three distinct stages in strategies of translation in this period. The first stage, 1610-90, saw the rise in discourses of traduction libre between 1635 and 1660. This was followed by defences of fidelity such as Daniel-Pierre Huet's De interpretandi in 1661. The second stage, 1690-1770, which corresponds to the period in which Lhéritier published her fairy tales, is classified by Tran-Gervat and Weinmann as "The Golden Age of Genius" (L'âge d'or du "genie"). They prefer this term to the oft-used description belle infidele as a better reflection of intellectual tensions in the period. These encompassed the debate known as the Querelle des Anciens et des Modernes ("Quarrel between the Ancients and the Moderns"), about the relative merits of classical Greek and Roman and modern French culture, as well as reflections on the origin of genius. The latter discussion led to development of the myth of the genius of the French language, a myth that contributed to the formation of the French literary canon and the establishment of French as the European language of knowledge, culture, and diplomacy. A natural or simple approach to translation that acknowledged the foreignness of translated texts and focused on capturing their "énergie" dominated the third stage between 1770 and $1815 .^{24}$

Influences from all three stages of translation are evident in the preface to Lhéritier's 1732 translation of Ovid's Heroides. In admitting that she has modified her source text to comply with eighteenth-century sensibilities ("I have toned it down slightly in places where good taste would have been offended"), Lhéritier clearly identifies herself as a practitioner of the traduction libre approach associated with Tran-Gervat's and Weinmann's first stage. ${ }^{25}$ She then defends the "great exactness" of her translation as if anticipating criticism from figures such as Huet. Lhéritier's expression of doubt about the success of her translation

\footnotetext{
${ }^{24}$ Yen-Maï Tran-Gervat and Frédéric Weinmann, 'Discours sur la traduction', in Histoire des traductions en langue française, pp. 249-329.

${ }^{25}$ Les épittres hérö̈ques d'Ovide, p. ix. This sentence is quoted in full in the epigraph at the start of this section.
} 
engages with debate about the nature of genius from the second stage. After lamenting the loss of grace in her translation, she considers the issue of whether genius was separable from language by questioning whether it is possible to translate Ovid's genius into French: "how do we render them [Ovid's graces] in a language [French] in which the genius is so different from that of his own?" ${ }^{26}$ Lhéritier adopts a distinctly modern response to this challenge. She identifies humanity's "love of variety" as the motivation for her decision to translate Ovid's letters into different poetic forms, celebrating the avoidance of uniformity in her text as an aesthetic choice designed to please "different tastes". ${ }^{27}$ Lhéritier therefore revises Ovid's text to make it correspond to the taste of her contemporary readers. Rather than Ovid's poetic genius, it is her judgement of taste that determines the final form of her translation. As discussed further below, Lhéritier's defence of the fairy tale genre and philosophy of history place her squarely on the modern side of the Querelle des Anciens et des Modernes. Although she also emphasises her attempts to give her verses a "natural and original" form, her creative approach to translation exemplifies this political position. ${ }^{28}$ Tellingly, it is her verses that receive this treatment: Lhéritier's deference to the "admirable poet" she translates does not, in her view, efface her ownership of the texts she has created.

The conflict between the ancient and modern definitions of history in the Querelle des Anciens et des Modernes is one of the most important influences on Lhéritier's approach to

\footnotetext{
26 “Malgré tous mes soins, il est sûr que cet admirable Poète aura encore perdu beaucoup de ses grâces dans ma traduction. Et comment les rendre toutes dans une Langue, dont le génie est si différent de celui de la sienne ?’: Les épîtres hérö̈ques d'Ovide, p. x.

27 “Comme je sais qu'on aime la variété, j’ai traduit ces Epîtres en différentes manières . . . et en évitant l'uniformité, le plus qu'il est possible, tâcher à satisfaire les goûts différents": Les épîtres hérö̈ques d'Ovide, p. $\mathrm{x}$.

28 “en conservant exactement ses pensées, j'ai fait tous mes efforts pour donner à mes Vers un tour naturel et original": Les épîtres hérö̈ques d'Ovide, p. ix.
} 
translation. ${ }^{29}$ The definition of history was a key issue in this debate. Alicia C. Montoya interprets the Querelle as a conflict about the concept of historical progress prompted by the re-emergence of Renaissance proto-historicism in France during the 1680s and 1690s. ${ }^{30}$ Modernes, including Lhéritier's close relation Charles Perrault, argued that history was a linear or diachronic progression moving forwards from the past to the perfection of the present - namely the century of Louis XIV.$^{31}$ According to this view of history, the continuous evolution of literature and human civilisation from the time of Greek and Roman antiquity meant that contemporary French culture was superior to classical culture. Moderne translators therefore aimed to remodel ancient texts and thus bring them into correspondence with modern taste, which they held to be more enlightened than classical taste. ${ }^{32}$ As outlined above, Lhériter adopted this approach in her translation of Ovid's Heroides. Charles Perrault articulated a similar philosophy for the 1695 edition of his collected verse tales, Grisélidis, nouvelle avec le conte de Peau d'Asne et celui des Souhaits ridicules. In the preface to the edition, Perrault defends his tales from accusations of frivolity. He claims that they were moral fables more deserving to be told than ancient tales such as the versions of Psyche by

\footnotetext{
${ }^{29}$ For two different perspectives on the Querelle, see Joan E. DeJean, Ancients against Moderns: Culture Wars and the Making of a Fin de Siècle (Chicago: University of Chicago Press, 1997), and Marc Fumaroli, 'Les abeilles et les araignées', in La querelle des Anciens et des Modernes: XVIIe-XVIIIe siècles, ed. Anne-Marie Lecoq (Paris: Gallimard, 2001), pp. 7-218.

${ }^{30}$ Medievalist Enlightenment: From Charles Perrault to Jean-Jacques Rousseau (Cambridge: DS Brewer, 2013), pp. 17-27.

${ }^{31}$ Alicia C. Montoya, Medievalist Enlightenment: From Charles Perrault to Jean-Jacques Rousseau (Cambridge: DS Brewer, 2013), pp. 21-35.

32 Tran-Gervat and Weinmann, 'Discours sur la traduction', pp. 276-277; Julie Candler Hayes, Translation, Subjectivity, and Culture in France and England, 1600-1800 (Stanford: Stanford University Press, 2009), pp. $121-137$.
} 
Apuleius and Lucien, which he dismisses as nothing more than "pure fiction" and "old wives' tales" ${ }^{33}$ Further, he declares that the worthiness of his fables was merited by their superior morality. ${ }^{34}$

The Ancien view of history was cyclical (or heterochronic), and emphasised a sense of continuity with the past. The defenders of ancient texts, including Nicolas BoileauDespréaux, Jean Racine, Jean de La Fontaine, and Jean La Bruyère, argued that the poetic genius of classical Greek and Roman authors established the standard of perfection by which modern texts should be judged. ${ }^{35}$ By definition, this concept of literary value excluded genres such as the novel and fairy tales which were closely associated with women writers. ${ }^{36}$ Ancien translators aimed to renew French culture by providing faithful translations that would give voice to the genius of the original text. ${ }^{37}$ The key difference between Ancien and Moderne approaches to translation was the amount of creative agency exercised by the translator. Both approaches conceptualised translation as an act of cultural mediation that permitted access to the past; they differed with respect to how the translator should mediate access to the past. The crucial question was whether the genius of the text would "speak for itself", or whether it

\footnotetext{
33 "La fable de Psyché écrite par Lucien et par Apulée, est une fiction toute pure et un conte de vieille comme celui de Peau d’Âne" (Grisélidis), in Tony Gheeraert (ed.), Contes Merveilleux: Perrault, Fénelon, Mailly, Préchac, Choisy et Anonymes (Paris: Honoré Champion, 2005), p. 104.

34 “Je prétends même que mes fables méritent mieux d'être racontées que la plupart des contes anciens . . . si l’on regarde du côté de la morale" (Grisélidis), in Contes Merveilleux, p. 104.

${ }^{35}$ Montoya, Medievalist Enlightenment, pp. 21-25; DeJean, Ancients against Moderns, pp. 16-30.

${ }^{36}$ DeJean, Ancients against Moderns, pp. 51-77.

${ }^{37}$ Tran-Gervat and Weinmann, 'Discours sur la traduction', pp. 276-277; Hayes, Translation, Subjectivity, and Culture in France and England, 1600-1800, pp. 121-137.
} 
needed to be adapted to "speak French". ${ }^{38}$ Lhéritier and her modern contemporaries defended the latter view.

Lhéritier's status as a female writer was another important influence on her approach to translation. As Marie-Alice Belle illustrates in her survey of the historiography of translations by early modern women, translation was a critical practice in the development of early modern women's writing, and female translators played an important role in the production of early modern texts. ${ }^{39}$ Recent scholarship emphasises the contribution of women translators to the development of early modern discourse on translation. Jean-Philippe Beaulieu's reading of Marie de Gournay's paratexts proposes that they set forth an authorial ethos that identifies Gournay as a theoretician of translation, and defends the poetics of her translations. Certainly Gournay's prefaces reframe the topos of modesty associated with early modern female writers and translators to assert her own voice as a translator and critic. ${ }^{40}$ Anne Dacier's intervention in the Querelle d'Homère, the final phase of the Querelle des Anciens et des Modernes known as "the Homer debate", challenged modern approaches to translation, in particular Perrault's comments in his four volume work Parallèle des Anciens et des Modernes (Comparison Parallel of the Ancients and the Moderns, 1688-1694). ${ }^{41}$ Julie Hayes argues that Dacier's approach to translation was neither classical nor modern but a

\footnotetext{
${ }^{38}$ The idea of making a text "speak French" was a recurring topos in traduction libre discourses: Hayes, Translation, Subjectivity, and Culture in France and England, pp. 122-125. See also Tran-Gervat and Weinmann, 'Discours sur la traduction', pp. 276-277.

${ }^{39}$ Marie-Alice Belle, 'Locating Early Modern Women’s Translations: Critical and Historiographical Issues', Renaissance \& Reformation/Renaissance et Reforme, 35 (2012), pp. 5-23.

${ }^{40}$ Jean-Philippe Beaulieu, ““ Moy Traductrice’: Le façonnement de la figure auctoriale dans le paratexte des traductions de Marie de Gournay", Renaissance \& Reformation/Renaissance et Reforme 35 (2012), pp. 121124.

${ }^{41}$ Hayes, Translation, Subjectivity, and Culture in France and England, pp. 121-134.
} 
hybrid approach based on the metaphor of the translator as an artist: "like a sculptor whose work is based on that of a painter". ${ }^{4}$

Like Gournay and Dacier, Lhéritier used the prefaces to her fairy tales to intervene in contemporary literary debates. She defended the aesthetics and morality of fairy tales as moderne literary texts, and responded to Boileau's attacks on women writers, in particular his criticism of Scudéry's (mis)use of history in her novels. ${ }^{43}$ Lhéritier's self-representation as a historian and a storyteller developed a theory of the origins of the fairy tale genre that established her authority as a translator of medieval texts while simultaneously defending the eloquence of female writers.

\section{History, Truth, and Translation in Lhéritier's Tales}

The historical framing of Lhéritier's tales can be understood as sophisticated literary strategy that drew on the rhetoric of translation to establish her authority as a scholar whose aim was to interpret the moral virtue of medieval French tales for a modern audience. The framing drew on two different sources of history: written accounts of the past recorded in medieval manuscripts, and oral stories recovered from storytellers recounting tales from Provençal troubadours. The exact relationship between these two sources is difficult to untangle since Lhéritier's references to written sources seem to contradict her claim that fairy tales are oral stories derived from tales by medieval troubadours. A close reading of the paratexts to Lhéritier's tales reveals a shift in her attitude towards the historical sources she translates. For

\footnotetext{
${ }^{42}$ This quote is a paraphrase of the preface to Dacier's 1712 translation of the Iliad: Hayes, Translation, Subjectivity, and Culture in France and England, p. 133.

${ }^{43}$ See in particular Boileau's Satire X and Dialogue sur les heroes de roman. On Lhéritier's response to Boileau's attacks see Helena Taylor, ‘Ancients, Moderns, Gender: Marie-Jeanne L’Héritier’s “Le Parnasse Reconnoissant, Ou, Le Triomphe de Madame Des-Houlières”, French Studies, 71 (2017), pp. 15-30.
} 
each of the tales published in Euvres meslées in 1696, Lhéritier claims to be faithfully retelling a story recorded in a source she refers to as a chronique (chronicle). However, by 1705 , this rhetoric of fidelity is tempered by Lhéritier's repudiation of her carefully constructed fiction that King Richard I was the author of La Tour ténébreuse. In 1717, in a new preface to a revised version of Marmoisan ou L'Innocente Tromperie, Lhéritier unapologetically states that she has added and removed facts according to her judgement about how best to tell the story of her heroine's military adventures. ${ }^{44}$

In Euvres meslées, Lhéritier identifies chronicles and oral stories she heard as a child as the sources for her tales. In Marmoisan and L'Adroite Princesse, chronicles provide descriptions of the characters featured in the tales. ${ }^{45}$ Lhéritier asserts that the chronicle for L'Adroite Princesse is incomplete beacuse it does not include the real names for each of the king's three daughters. The names recorded in the chronicle-Nonchalante, Babillarde, and Finette- are names given to the princesses in accordance with the custom of naming with reference to good qualities or character defects. The heroine, Finette, is named for her cunning; Nonchalante for her indolence; Babillarde for her incessant conversation. ${ }^{46}$ In Les Enchantements de l'Éloquence, Lhéritier claims that her chronicle provides an account of a heated discussion between the father and stepmother of Blanche, the heroine, about Blanche's penchant for reading novels. In response to his wife's Boileau-esque attack on novels, Blanche's father defends their didactic value as texts that punish vice and reward virtue. ${ }^{47}$

\footnotetext{
${ }^{44}$ Marmoisan is technically not a fairy tale due to the absence of a magical setting. It is included it in the present analysis because it contains narrative elements associated with the folklore and fairy tale tradition: Seifert and Stanton, Enchanted Eloquence, p. 63.

45 'Marmoisan', p. 45; 'L’Adroite Princesse', p. 94.

46 'L’Adroite Princesse', pp. 94-96.

47 'Les Enchantements de l'Éloquence', p. 76.
} 
Lhéritier makes the same argument about the moral poetics of fairy tales in L'Adroite Princesse and Lettre à Madame D.G**. ${ }^{48}$ In Les Enchantements de l'Éloquence, Lhéritier speaks through the character of Blanche's father to defend the reading of novels. His arguments echo those made by Huet in his Traité de l'origine des romans (Treatise on the origins of novels) and articulate the philosophy of history that underpins Lhéritier's approach to translation of historical sources. ${ }^{49}$ Blanche's father argues it is more beneficial for young people to read novels rather than history because novels provide a better moral example. History, which he claims is "entirely subject to truth", shows the sometimes shocking reality of human nature. ${ }^{50}$ He suggest that novels, by contrast, offer an idealised version of how men "ought to be, and thereby encourage aspiration to perfection". ${ }^{51}$ Lhéritier follows this defence of the moral poetics of fiction with a disclaimer that she has not exaggerated Blanche's father's sympathy for novels: "I recount only what is in my chronicle; I am a historian, and a historian must not take sides". ${ }^{52}$ In the French version of this statement, Lhéritier distinguishes between female and male historians but argues that the obligation of fidelity applies to both.

\footnotetext{
48 'L'Adroite Princesse', p. 114; 'Lettre à Madame D.G**', p. 38. See also Sophie Raynard, 'New Poetics versus Old Print: Fairy Tales, Animal Fables, and the Gaulois Past', Marvels \& Tales 21 (2007), pp. 93-106. ${ }^{49}$ Huet's treatise was first published as the preface to the first edition of Lafayette's Zayde in 1669 under the title Lettre de M. Huet à M. de Segrais de l'origine des romans. Lhéritier refers to it in her Lettre à Madame D. $G^{* *}$, pp. $36-37$.

50 “étant entièrement assujettie à la vérité”: 'Les Enchantements de l’Éloquence', p. 76.

51 “L'histoire peint les hommes comme ils sont, et les romans les représentent tels qu'ils devraient être, et semblent par là les engager d'aspirer à la perfection': 'Les Enchantements de l'Éloquence', p. 76.

52 “je raconte seulement ce que porte ma chronique ; je suis historienne, et une historienne, aussi bien qu'un historien, ne doit point prendre de parti’: 'Les Enchantements de l'Éloquence', p. 77.
} 
In representing herself as a historian, Lhéritier draws on the rhetoric of fidelity to establish her authority as a truthful narrator. Yet Lhéritier's use the term chronique is inconsistent with the term's association with official historical records — and the type of history she tells is different to that which is ordinarily recorded in chronicles. The 1694 edition of the Dictionnaire de l'Académie française defines chronique as a term referring to the chronological compilation of ancient histories. ${ }^{53}$ In referring to chroniques as historical sources recording stories about women, Lhéritier expands the definition of history beyond narration of the deeds of great men. ${ }^{54}$ Lhéritier makes two arguments about the origins of fairy tales in support of this aim. First, Lhéritier claims that there is a direct link between the troubadours and the female storytellers responsible for the continued circulation of their tales. For example, she offers the tale of Les Enchantements de l'Éloquence to the Duchesse d'Epernon as the written version of "one of those Gallic fables that apparently come straight from the once celebrated storytellers or troubadours of Provence". ${ }^{55}$ Lhéritier identifies two different groups of female storytellers involved in the preservation of the troubadours' tales. The first are the mothers, grandmothers, and nurses who kept the memory of the tales alive by telling them to children. ${ }^{56}$ The second are the educated, "charming ladies" of the salon who have brought back the glorious time of the fairies by rescuing the troubadours' tales from the "mouths of the lower classes" ${ }^{57}$ Lhéritier foregrounds the importance of the latter

\footnotetext{
53 “On le dit ordinairement des anciennes histoires dressées suivant l'ordre des temps”, p. 189.

${ }^{54}$ Seifert and Stanton, Enchanted Eloquence, pp. 69-70 (n72).

55 “une de ces fables gauloises qui viennent apparemment en droite ligne des conteurs ou troubadours de Provence, si célèbres autrefois”: 'Les Enchantements de l'Éloquence', p. 69.

56 'Les Enchantements de l'Éloquence', p. 70. Lhéritier borrows this trope from the conclusion of Perrault's Peau d'Âne. See also 'Lettre à Madame D.G**', p. 37.

57 “charmantes dames”: 'Lettre à Madame D.G**’, p. 36; “ces contes se sont remplis d'impuretés en passant par la bouche du petit peuple": 'Lettre à Madame D.G**', p. 39.
} 
group of literate female storytellers in Les Enchantements de l'Éloquence by claiming that she first heard the tale from a women educated in classical Greek and Roman culture who was "even more erudite in Gallic antiquities". 58

Lhéritier's representation of fairy tales as the result of a collaboration between the troubadours and educated salon women was designed to elevate the status of the genre by associating it with an ancient Gallic literary tradition. ${ }^{59}$ Her second argument challenging the official definition of history illustrates this intention by declaring that stories from this indigenous literary tradition are superior to those from classical antiquity. In other words, Lhéritier places the narration of history in the troubadours' tales (a history that includes stories by and about women) above the classical Greek and Roman texts venerated by male scholars. In doing so, Lhéritier rejects the narrow definition of literary value privileged by (male) critics, by stating that her tales are not written for them:

We write to instruct and to entertain; we write also to instruct and entertain our friends. ... What does it matter if people without taste are not pleased with works that are not made for them $?^{60}$

\footnotetext{
58 ، $[\mathrm{u}]$ ne dame très instruite des antiquités grecques et romaines, et encore plus savante dans les antiquités gauloises”: 'Les Enchantements de l'Éloquence', p. 70.

${ }^{59}$ Alicia C. Montoya, 'Contes du Style des Troubadours: The Memory of the Medieval in Seventeenth-Century French Fairy Tales', in Karl Fugelso and Carol L. Robinson (eds.), Medievalism in Technology Old and New (Cambridge: Brewer, 2008), pp. 8-13.

60 “On écrit pour s'instruire et pour se divertir ; on écrit aussi pour instruire et pour divertir ses amis . ... Qu'importe que des gens sans goût soient peu contents d'ouvrages qui n'ont pas été faits pour eux": 'Lettre à Madame D.G**', p. 40. My translation with reference to Seifert and Stanton, Enchanted Eloquence, p. 291.
} 
Lhéritier makes her intervention in the Querelle des Anciens et des Modernes explicit in the metatextual commentary at the end of Les Enchantements de l'Éloquence. After suggesting that her tale is no more incredible than many stories from Ancient Greece, Lhéritier defends the eloquence of women writers by claiming that fairies, a metaphorical reference to literary salon women, are just as capable of performing miracles as the gods of ancient fables. ${ }^{61}$ This celebration of the eloquence of woman writers as the modern embodiment of fairy magic is further illustrated by the name Lhéritier gives to the fairy who assists the heroine, Eloquentia nativa. ${ }^{62}$ The proverb on which the tale is based, that "sweet and courtly language is more valuable than a rich inheritance", identifies eloquence as the heroine's most important quality. $^{63}$

Lhéritier was not the only seventeenth-century writer who attempted to redefine history to include the stories of women. As DeJean and Faith E. Beasley have demonstrated, the genre of historical fiction developed by women writers including Scudéry, Lafayette, Villedieu, and Montpensier proposed a radical revision of the notion of official history. ${ }^{64}$

\footnotetext{
${ }^{61}$ See the quote here below at n65. In emphasising the French nature of her sources, Lhéritier fails to acknowledge any intellectual debt to the sixteenth-century Italian tales by Giovan Francesco Straparola and Giambattista Basile: Bottigheimer and Raynard, 'Marie-Jeanne Lhéritier de Villandon', pp. 127-128 and 137. See also Raymonde Robert, 'Les conteurs français lecteurs de Basile: Mlle Lhéritier, Mlle de La Force, Un auteur anonyme, Cazotte', Romanic Review 99 (2008), pp. 333-348.

${ }^{62}$ Allison Stedman, 'Charmed Eloquence: Lhéritier's Representation of Female Literary Creativity in Late Seventeenth-Century France', Cahiers du dix-septième 9 (2005), pp. 116-119; Raynard, 'New Poetics versus Old Print', pp. 94-99.

63 "Doux et courtois langage /Vaut mieux que riche apanage": 'Les Enchantements de l'Éloquence', p. 91.

${ }^{64}$ DeJean, Tender Geographies: Women and the Origins of the Novel in France (New York: Columbia University Press, 1991), pp. 127-140; Beasley, Revising Memory: Women's Fiction and Memoirs in Seventeenth-Century France (New Brunswick: Rutgers University Press, 1990), pp. 72-128. See also Domna C.
} 
Lhéritier's descriptions of her short prose works nouvelle (novella), nouvelle historique (historical novellas), and nouvelle hëroique \& satyrique (heroic and satiric novella) in Euvres meslées emphasises the connection between her writing and the proliferation of histoires, nouvelles galantes, histoires galantes, mémoires secrets, annales galantes, and histoires des amours in the latter part of the seventeenth century. In associating her writing with a long tradition of literary production by women writers, Lhéritier sought to legitimise her work, and the writing by her salonnière contemporaries, as the continuation of a national literary project begun by the troubadours. Her claim that women's writing was as important as classical Greek and Roman literature drew on a fictionalised medieval past to include stories by and about women in the French literary canon: "Tale for tale, it seems to me that those from Gallic antiquity are just as valuable as those from Greek antiquity; and the fairies are no less entitled perform wonders than the gods of Fables". ${ }^{65}$

The framing of Lhéritier's writing as historical fiction is further developed in La Tour ténébreuse. Lhéritier frames the two fairy tales embedded in this volume as stories told by Richard the Lionheart to Blondel de Nesle, a troubadour in Richard's service who helps him to escape from imprisonment in the village of Linz. The full title of the collection introduces this framing strategy:

THE DARK TOWER AND LUMINOUS DAYS, ENGLISH TALES, Accompanied by Short Histories, and taken from an ancient Chronicle composed by RICHARD

\footnotetext{
Stanton, 'The Demystification of History and Fiction in Villideau's Annales Galantes', Papers on French Seventeenth-Century Literature, 31 (1987), pp. 1-32.

65 “Contes pour contes, il me paraît que ceux de l'antiquité gauloise valent bien à peu près ceux de l'antiquité grecque ; et les fées ne sont pas moins en droit de faire des prodiges que les dieux de la Fable”: 'Les Enchantements de 1'Éloquence', p. 91.
} 
nicknamed the LIONHEART, King of England. With the Story of various Adventures of this King. ${ }^{66}$

This title page does not mention Lhéritier as author, nor does it include any reference to any author other than King Richard I. Although it was not unusual for works by seventeenthcentury female writers to be published anonymously, authorial attribution of some description normally appears on the title page. ${ }^{67}$ For instance, the title pages of Lhéritier's Euvres meslées (1696) and Les Caprices du destin, ou Recueil d'histoires singulières et amusantes (1717) identify their author as Mademoiselle L'H***, and Lhéritier's full name appears on the title page of her 1734 translation of Ovid. Given that La Tour ténébreuse was published in 1705, long after Lhéritier's literary credentials had been established, it seems likely that the failure to refer to Lhéritier is a deliberate omission designed to represent the twelfth-century king of England as the true author of the text.

The paratexts introducing La Tour ténébreuse further emphasise the representation of Richard I as the author. The preface does not identify Lhéritier by name; rather, it opens with a short account of Richard I's biography, and mentions the failure of historians to refer to his literary talents. He is represented as a celebrated twelfth-century writer whose contes and historettes galantes were "imitated by several [Provençal] troubadours". ${ }^{68}$ The author of the preface (Lhéritier) then claims to have discovered Richard I's forgotten texts in a 1308

\footnotetext{
${ }^{66}$ The following is the full title of La Tour ténébreuse et les jours lumineux (Paris: Barbin, 1705): LA TOUR TENEBREUSE ET LES JOURS LUMINEUX, CONTES ANGLOIS, Accompagnez d'Historiettes, \& tirez d'une ancienne Chronique composée par RICHARD, surnommé COEUR DE LION, Roy d'Angleterre. Avec le Récit de diverses Avantures de ce Roy.

${ }^{67}$ DeJean, Tender Geographies, pp. 1-5.

68 “ils furent même imités de plusieurs troubadours": La Tour ténébreuse, p. 116.
} 
manuscript: Chroniques et fabliaux de la composition de Richard roi d'Angleterre, recueillis tout de nouvel, et conjoints ensemble par le labour de Jehan de Sorels. Lhéritier's detailed description of the content and composition of this source, as well as her inclusion of the original text of the Provençal and old French songs she claims to have translated into modern French, evidence her credentials as a historian and translator. Montoya explains that Lhéritier's descriptions of her medieval sources are "surprisingly accurate" given the relative lack of French medievalist studies in $1705 .{ }^{69}$ The three songs she reproduces in the preface to La Tour ténébreuse are authentic medieval texts, and two of the three are correctly attributed to Blondel de Nesle and Richard I. ${ }^{70}$ The representation of Lhéritier as a translator faithfully transmitting the voice of King Richard is made explicit in the letter of dedication to the Duchesse de Nemours. After respectfully complimenting the Duchesse, Lhéritier's dedicatory verse declares:

See in me King Richard

Who comes here to share with you

[The events] that produced my prose and rhymes. ${ }^{71}$

Lhéritier's denial of her creative agency is merely a convenient fiction. In Euvres meslées, she openly acknowledges the changes she has made to her oral sources. In the paratexts to Marmoisan, Lhéritier identifies a salon storytelling session in which Perrault's tales were praised and new tales invented as the inspiration for what she claims is a spontaneous

\footnotetext{
${ }^{69}$ Montoya, 'Contes du Style des Troubadours', p. 18.

${ }^{70}$ La Tour ténébreuse, 121-22. Montoya, 'Contes du Style des Troubadours', pp. 18-19.

71 "Voyez-en moi le roi Richard /Qui vient ici vous faire part /De ce que produisit et ma prose et ma rime":

La Tour ténébreuse, p. 125.
} 
"embellishment" of an oral tale: "what I have just told you is essentially the naive tale of Marmoisan, as it was told to me when I was a child" ${ }^{72}$ At the end of L'Adroite Princesse, Lhéritier admits she has "embroidered" and lengthened the tale she heard from her governess. ${ }^{73}$ In La Tour ténébreuse, Lhéritier extends this creative licence to her written sources. The epigraph to this chapter includes a statement made immediately before the first fairy tale included in the narrative (Ricdin-Ricdon); here Lhéritier asserts her right to make changes to Richard I's chronicle. She concludes that it is her voice addressing the reader: "It is not therefore King Richard who speaks, it is me" ${ }^{74}$ Lhéritier also makes unacknowledged deviations from her written source texts. Raymonde Robert states that Lhéritier's translation of the first Provençal song reproduced in her preface has nothing in common with the original text. ${ }^{75}$ This song is also wrongly attributed to Blondel and Richard I. Although it is an authentic thirteenth-century song, Montoya notes that in fact it was composed by the troubadour Blacatz (Blacas de Blacas III). ${ }^{76}$

Lhéritier's creative approach to translation is exemplified by the preface to the 1717 republication of Marmoisan under the title L'Amazone française. ${ }^{77}$ This preface states that

\footnotetext{
72 "Je contai celui de Marmoisan, avec quelque broderie qui me vint sur-le champ dans l'esprit . . ce que je viens de vous dire est toujours au fond bien naïvement le conte de Marmoisan, tel qu'on me l'a conté, quand j'étais enfant": 'Marmoisan', pp. 44 and 65.

73 “Je vous avoue que j'ai l'ai brodée et que je vous l'ai contée un peu au long”: 'L'adroite Princesse', p. 113.

${ }^{74}$ La Tour ténébreuse, p. 138. For the full quotation see the quotation with which the present chapter opens.

${ }^{75}$ Contes: Mademoiselle Lhéritier, p. $129(\mathrm{n} 1)$.

${ }^{76}$ Montoya, 'Contes du Style des Troubadours', pp. 18-19.

${ }^{77}$ This tale appears in Les Caprices du destin, ou Recueil d'histoires singulières et amusantes (Paris: Huart, 1717).
} 
the only thing retained from the original source is the valiant character of the heroine. ${ }^{78}$ Lhéritier does not seek to justify her rewriting of history—she states unapologetically: "I have suppressed many facts, and added a great number of others that seemed to me more amusing and appropriate to the subject". ${ }^{79}$ Moreover, Lhéritier informs the reader that she has revised ancient history according to events in recent history, namely the military adventures of a young woman of nobility in the present century. Ruth Bottigheimer and Sophie Raynard suggest that this woman is Madame de Saint-Balmon, whose adventures inspired Jean-Marie de Vernon's L'amazone chrétienne, ou, les Aventures de Madame de Saint-Balmon (1678). ${ }^{80}$ Lhéritier identifies a similarity between this modern Amazon and her ancient counterpart such that she has attributed the victories of the former to the latter. ${ }^{81}$

Lhéritier's representation of herself as a historian and her tales as translations of historical texts constructs her authorial identity as that of a faithful narrator recounting tales she learned from authoritative sources. Where she frames her fairy tales with commentary that emphasises the medieval and oral origins of these sources, Lhéritier also identifies herself as a scholar whose writing translates incomplete sources for the modern, literate audience of the salon. As her literary oeuvre developed, Lhéritier's declarations of fidelity were increasingly

\footnotetext{
78 “J'ai conservé simplement le caractère de fille vaillante": 'Variantes de Marmoisan', in Contes: Mademoiselle Lhéritier, p. 66.

79 “'mais du reste j'ai supprimé beaucoup de faits, et en ai ajouté encore un plus grand nombre d'autres qui m'ont paru plus amusants, et plus convenables au sujet”: 'Variantes de Marmoisan', p. 66.

${ }^{80}$ Bottigheimer and Raynard, 'Marie-Jeanne Lhéritier de Villandon', p. 133.

81 “La conformité de sa destinée avec celle de Marmoisan-Léonore me fit prendre le parti de mettre ces principales victoires sous le nom de cette ancienne guerrière": 'Variantes de Marmoisan', p. 67.
} 
modified by assertions of her creative agency as a modern writer. This rhetorical strategy served multiple aims. First, it allowed Lhéritier to develop a genealogy of fairy tales as modern retellings of troubadour tales. The identification of a historical trajectory between the troubadours and the salon women who reinvented their tales claimed a voice for women writers by associating their literary production with a celebrated tradition of Gallic storytelling. Second, Lhéritier's emphasis on her status as a historian simultaneously disguised her authorial creativity and revised the definition of literary history to include women's voices. The history Lhéritier claimed to be writing was a national one. She emphasises the Gallic nature of her sources and remodels them to present an idealised version of history supporting the modern side of the Querelle des Anciens et des Modernes. Her contemporary reputation as an erudite, literary theoretician lent credibility to these attempts to broaden the French literary canon. Within salon circles her work was widely read, and her theory of the origins of fairy tales continues to influence the definition of the genre.

Lhéritier's creative use of authentic medieval texts as inspiration for her fairy tales illustrates the complex relationship between history, truth, and fidelity in her approach to translation. Like Montoya, I read Lhéritier's literary reconstruction of medieval texts as an example of the practice of "conjectural history". ${ }^{82}$ Lhéritier's fairy tales are texts created to explain the moral truths about human nature that she reads in her fragmentary sources. Her fairy tales blend history and fiction in their translation of the moral essence of these sources for a modern (female) audience. In the metatexual and paratextual commentary framing her tales, Lhéritier emphasises her creative agency as a storyteller who directly addresses her readers. Her authorial voice is not mediated by her sources; she determines the form and content of her tales. This dynamic approach to historical truth underpins Lhéritier's theory of

\footnotetext{
${ }^{82}$ Montoya, 'Contes du Style des Troubadours', pp. 16-22.
} 
translation: she does not offer a literal translation of history — instead, she reimagines it, by recreating her sources in a modern literary voice.

Lhéritier's creative approach to translation was both a necessary response to an absence of documentary evidence, and a sophisticated literary strategy designed to defend the eloquence of women writers. The moral imperative of this literary project was the translation of the virtuous sentiments of troubadour tales for the modern audience of the seventeenthcentury literary salon. This project involved multiple acts of translation as Lhéritier transformed a popular tradition of storytelling into texts published for an elite audience. In 'transporting' the troubadours' tales from the medieval past to the modern present, Lhéritier claimed to have restored the moral virtue of stories that had been "filled with impurities in passing through the mouths of the lower classes". ${ }^{83}$ Lhéritier achieved this goal by using the sophisticated, delicate language of salon conversation to translate the troubadours' maxims. ${ }^{84}$ Yet in applying modern strategies of translation to purify her medieval sources, Lhéritier did more than simply restore the "original" versions of the troubadours' tales. She revised her source texts to defend the eloquence of female voices and drew on the rhetoric of translation to defend her creative agency and the intellectual contribution of women writers to the seventeenth-century literary field.

\section{Works by Marie-Jeanne Lhéritier}

Le Triomphe de Mme Des-Houlières, receue dixième muse au Parnasse (Paris: Claude Mazuel, 1694)

Cuvres meslées . . de Mlle L'H** (Paris: Guignard, 1696)

\footnotetext{
83 “ces contes se sont remplis d'impuretés en passant par la bouche du petit peuple”: 'Lettre à Madame D.G**', p. 39 .

84 'Lettre à Madame D.G**', pp. 35-39.
} 
L'Apothéose de Mademoiselle de Scudéry (Paris : Moreau, 1702)

L'Érudition enjouée, ou Nouvelles sçavantes, satyriques et galantes, écrite à une dame française qui est à Madrid (Paris: Ribou, 1703)

La Tour ténébreuse et les jours lumineux (Paris: Barbin, 1705)

Mémoires de M. L. D. D. N. contenant ce qui s'est passé de plus particulier en France pendant la guerre de Paris, jusquà la prison du cardinal de Retz, arrivée en 1652. Avec les différens caractères des personnes, qui ont eu part à cette guerre (Cologne, 1709)

Les Caprices du destin, ou Recueil d'histoires singulières et amusantes (Paris: Huart, 1717) Les épîtres hérö̈ques d'Ovide, traduites en vers françois, par Mlle L'Héritier (Paris: Brunet, 1732) 


\title{
CHAPTER 10
}

\section{Female Translators and Print Culture in Sixteenth-Century Germany ${ }^{1}$}

\author{
Hilary Brown
}

Did women have a Renaissance? When Joan Kelly famously posed this question forty years ago, the answer seemed to be 'no'. The intervening period has seen a wealth of research on women in different European countries - Italy, France, England - and the question appears to have become redundant. ${ }^{2}$ Translation was early identified in the new research as a key area of activity: it was noted that more women were active as translators during the Renaissance than at any previous time in history. This phenomenon has been interpreted in different ways, at least with regard to England. The traditional (and still dominant) view is that translation offered women a respectable way of participating in cultural life: they were subjected to a "rule of silence" but as translation was a "degraded activity" it was one of the few literary pursuits deemed appropriate for them. ${ }^{3}$ Women were expected to restrict

\footnotetext{
${ }^{1}$ I gave a presentation based on this research at the conference 'Translators and Printers in Renaissance Europe: Framing Identity and Agency’ (Institue of Modern Languages Research, University of London, 29-30 September 2016). I am grateful to colleagues in Birmingham who read a draft of the article: Prof. Andrew Ginger, Dr. Nigel Harris, Prof. John Klapper, and Dr. Elizabeth L’Estrange.

2 Joan Kelly's seminal essay 'Did Women Have a Renaissance?' was published in Renate Bridenthal and Claudia Koonz (eds.), Becoming Visible: Women in European History (Boston: Houghton Mifflin, 1977), pp. 137-164. It was replaced in the third edition (1998) with an updated account by Carole Levine on 'Women in the Renaissance', focusing on Italy, France and Britain.

${ }^{3}$ Margaret P. Hannay, 'Introduction', in Margaret Patterson Hannay (ed.), Silent But for the Word: Tudor Women as Patrons, Translators and Writers of Religious Works (Kent, OH: The Kent State University Press, 1985), pp. 4 and 8. See also Tina Krontiris, Oppositional Voices: Women as Writers and Translators in the
} 
themselves to religious works and tended to produce translations for private consumption by their immediate circle (even if they then occasionally chose surprising source texts or subverted their source texts in order to assert their own agency). The alternative view, however, seeks to place women's translation activity in a broader context and, crucially, acknowledges at the outset that translation was far from being a degraded or second-rate literary activity but assumed a central importance in Renaissance culture. Focusing in particular on the circumstances of the early print trade, a number of studies are emerging which suggest that female translators were not so different from their male counterparts and that they used the new medium of print to position themselves at the centre of key religious and political developments. ${ }^{4}$

For all this valuable work, we hear very little indeed about female translators in Germany. ${ }^{5}$ In fact, the question of whether women had a Renaissance still seems pertinent here. There is general agreement that women in sixteenth-century Germany played a marginal role in cultural life. ${ }^{6}$ Women were largely confined to the domestic sphere and far

English Renaissance (London and New York: Routledge, 1992); and Jaime Goodrich, Faithful Translators: Authorship, Gender, and Religion in Early Modern England (Evanson, IL: Northwestern University Press, 2014).

${ }^{4}$ See e.g. Micheline White, 'Renaissance Englishwomen and Religious Translations: The Case of Anne Lock's “Of the Markes of the Children of God” (1590)', English Literary Renaissance, 23 (1999), pp. 375-400; Brenda M. Hosington, 'Women Translators and the Early Printed Book', in Vincent Gillespie and Susan Powell (eds.), A Companion to the Early Printed Book in Britain 1476-1558 (Cambridge: Brewer, 2014), pp. 248-271.

${ }^{5}$ For example, German women are not included in Diana Robin etc. (eds.), Encyclopedia of Women in the Renaissance (Santa Barbara: ABC-Clio, 2007) and thus not in Brenda Hosington and Hannah Fournier's survey in that volume of 'Translation and Women Translators', pp. 369-375.

\footnotetext{
${ }^{6}$ See, for instance, Helen Watanabe-O'Kelly, 'Women's Writing in the Early Modern Period', in Jo Catling (ed.), A History of Women's Writing in Germany, Austria and Switzerland (Cambridge: Cambridge University
} 
fewer women than men produced literature of any kind. True, there was a handful of women who achieved some fame as writers such as the Protestant polemicist Argula von Grumbach who wrote a series of bestselling pamphlets in the 1520s in support of Lutheran reform. In general, however, women who took up their pens tended to compose only literature which was suitably devout or didactic (religious songs or poetry, prayer books, maternal advice manuals) and were discouraged from making their work public through publication, particularly under their own names. Grumbach herself faced censure on account of her sex: she was told that women should hold their silence in religious debate (with reference to St Paul's well known dictum in 1 Corinthians 14: 34) and was sent a distaff, and she appears to have been pressurised by her family to refrain from publishing after a couple of years. ${ }^{7}$ But could it be the case that translation presented women with alternative modes of agency? Could there be a hidden tradition of female translators in Germany who, like their counterparts in England, negotiated the new possibilities offered by the development of print to become active agents in cultural exchange?

This chapter breaks new ground by examining the topic of women and translation in the German-speaking countries in what might loosely be termed the Renaissance, i.e. the long

Press, 2000), pp. 27-44 and Anna Carrdus, 'Women's Writing in the Context of their Lives, 1520-1720', in Max Reinhart (ed.), Early Modern German Literature 1350-1700 (Rochester, NY: Camden House, 2007), pp. 869-903.

\footnotetext{
${ }^{7}$ See Barbara Becker-Cantarino, 'Frauen in den Glaubenskämpfen: Öffentliche Briefe, Lieder und Gelegenheitsschriften', in Gisela Brinker-Gabler (ed.), Deutsche Literatur von Frauen (2 vols., Munich: Beck, 1988), I, pp. 149-172 (especially pp. 155-158). Becker-Cantarino argues that a satirical poem addressed to Grumbach by an Ingolstadt student is indicative of contemporary attitudes towards women: "Daß ihr nit solt Disputieren, / Sonder das hauß dahaym Regieren./ Vnd in der kirchen schweygen still”... [You women should not engage in debate but rule your houses and should keep silent in the churches] (p. 157).
} 
sixteenth century $(\mathrm{ca} \cdot 1500-1630){ }^{8}$ It seeks to identify the first women in Germany to see their translations in print and considers their publications in detail for the first time, paying particular attention to the context of book history. This means not treating individual translations in isolation but as "one of a range of works published at the same time on the same subject and in similar socio-historical circumstances" and taking into account factors such as "the ideological motivations of both translator and printer". ${ }^{9}$ The chapter thus extends the boundaries of research in a number of different fields. In the first place, it helps us to build up a more complete and accurate picture of German literary history by shedding new light on the activities of literary and intellectual women and drawing attention to the significance of texts barely discussed to date in the secondary literature. Second, it adds new perspectives to the research on female translators in Europe in past centuries and helps us to refine our thinking about gender and translation. Furthermore, this chapter makes a contribution to the history of translation and print culture in early modern Europe- $\mathrm{a}$ burgeoning area of research where, despite a recognition that across the continent there was a "radically integrated market for books and texts", Germany has received relatively little attention. $^{10}$

\footnotetext{
${ }^{8}$ The terms 'Renaissance' and 'Germany' are of course not ideal—-there has been much debate about whether the former can or should be applied in the German context, while the second is anachronistic_-but they will be used in this article as shorthand. For a discussion of the Renaissance label, particularly with reference to German women writers, see Albrecht Classen, 'Frauen in der deutschen Reformation: Neufunde von Texten und Autorinnen sowie deren Neubewertung', in Paul Gerhard Schmidt (ed.), Die Frau in der Renaissance (Wiesbaden: Harrassowitz, 1994), pp. 179-201.

${ }^{9}$ Hosington, ‘Women Translators', p. 248.

${ }^{10}$ See José María Fernández and Edward Wilson Lee, 'Introduction', in José María Fernández and Edward Wilson Lee (eds.), Translation and the Book Trade in Early Modern Europe (Cambridge: Cambridge University Press, 2015), pp. 1-21, at p. 2. Most of the research has focused on England, e.g. S. K. Barker and Brenda M.
} 


\section{A lost tradition?}

At first, the situation looks disappointing: there is no tradition of female translators in Renaissance Germany comparable to that in other countries. Figures for England, for instance, suggest that at least twenty-eight women produced at least fifty-two translations in this period, while in France over ten per cent of the approximately 100 women writers we know about were active as translators. In Germany, no woman appears to have worked on translation during the entire sixteenth century; women seem to have played no part in the international print culture of the European Renaissance. ${ }^{11}$

We need, however, to be cautious, as there is much we do not yet know about translation in sixteenth-century Germany. Sources of information are scantier for Germany than for other countries, but it is possible that there was less translation activity overall here

Hosington (eds.), Renaissance Cultural Crossroads: Translation, Print and Culture in Britain, 1473-1640 (Leiden: Brill, 2013) and A. E. B. Coldiron, Printers Without Borders: Translation and Textuality in the Renaissance (Cambridge: Cambridge University Press, 2015); see the only essay on Germany in the special issue of Renaissance Studies: Jonathan Green, 'Translating time: chronicle, prognostication, prophecy', Renaissance Studies, 29 (2015), pp. 162-177.

${ }^{11}$ The figures are taken from Hosington and Fournier, 'Translation and Women Translators'. I have found no female translators in the following: Wilhelm Kühlmann etc. (eds.), Frühe Neuzeit in Deutschland 1520-1620: Literaturwissenschaftliches Verfasserlexikon, (5 vols., Berlin: de Gruyter, 2011-2016)—at the time of writing I have been able to consult the first three volumes. The standard reference work for women writers in sixteenthcentury Germany is still Lotte Träger's unpublished $\mathrm{PhD}$ thesis from 1943. Träger mentions just one translator, Anna Palantin, who supposedly translated the psalms of Paulus Melissus Schede. See Lotte Träger, 'Das Frauenschrifttum in Deutschland von 1500-1650' (PhD diss., Charles University, Prague, 1943), p. 23. However, the translator is not German but Dutch: she is Johanna van Pallandt (Pallantia), niece of Karel Utenhove. See Jane Stevenson, Women Latin Poets: Language, Gender and Authority from Antiquity to the Eighteenth Century (Oxford: Oxford University Press, 2005), p. 240. 
than elsewhere. ${ }^{12}$ This could have been due in part to the nature of the German Reformation: the contemporary politico-theological debate was carried out for ideological reasons in the vernacular and there was little need for printers to import material from abroad: "Reformation printing in Germany is totally dominated by Luther and his collaborators and adversaries. The German Reformation is very much a home-grown affair, especially in the vernacular. The theological quarrels, for example with Calvin, were communicated in Latin but not translated into German." ${ }^{\prime 13}$ This stands in contrast to England where there was no national reformer of Luther's stature and where different factions seized on like-minded continental writers to further their agendas, particularly under Elizabeth I, making England "perhaps the biggest importer of translations in the whole of Europe". ${ }^{14}$ Nevertheless, it is clear that in Germany translation was still a feature of literary and intellectual life. From the late fifteenth century we find humanist scholars such as Johann Reuchlin and Willibald Pirckheimer translating

\footnotetext{
${ }^{12}$ At present precise data are not available. There is no equivalent to the 'Renaissance Cultural Crossroads Catalogue', http://www.hrionline.ac.uk/rcc/ (accessed 8 July 2016); the online 'Verzeichnis der im deutschen Sprachbereich erschienenen Drucke des 16. Jahrhunderts' (https://www.bsb-muenchen.de/kompetenzzentrenund-landesweite-dienste/kompetenzzentren/vd-16/, accessed 8 July 2016) does not allow the user to search specifically for translations. There is no printed reference work for Germany to match Paul Chavy, Traducteurs d'autrefois: moyen âge et renaissance; dictionnaire des traducteurs et de la littérature traduite en ancien et moyen français (842-1600), (2 vols., Paris: Champion-Slatkine, 1988) or Gordon Braden etc. (eds.), The Oxford History of Literary Translation in English (4 vols., Oxford: Oxford University Press, 2010), II.

${ }^{13}$ Francis M. Higman, 'Ideas for Export: Translations in the Early Reformation', in Jean R. Brink and William F. Gentrup (eds.), Renaissance Culture in Context: Theory and Practice (Aldershot: Scolar, 1993), p. 107. Higman may be overstating the case here but Stephen Füssel asserts that "Approximately one-third of the German-language book production in the first half of the sixteenth century can be accounted for by Luther's writings alone.” Stephan Füssel, 'Early Modern German Printing', in Max Reinhart (ed.), Early Modern
} German Literature 1350-1700 (Rochester, NY: Camden House, 2007)pp. 217-246, at p. 236.

${ }^{14}$ Higman, 'Ideas for Export', p. 109. 
Latin and Greek texts as part of efforts to make classical sources accessible to a large readership (even if this activity seems to tail off after the mid-sixteenth century, in comparison again to England $)^{15}$; we find a steady stream of translations of contemporary European literature into German, particularly in the wake of Luther's own revolutionary work as a translator and the new status this accorded the German language; and we find the literati taking forward the legacy of the Reformation and promoting translation for political and national aims within the Sprachgesellschaften (language societies) which sprang up from c. 1617 onwards. ${ }^{16}$ But, in all this, the translators we read about are men; it seems that opportunities for women to take part in these developments were limited.

Indeed, circumstances were stacked against any aspiring female translator. In the first place, there is the question of gender ideology: while Renaissance humanism is now regarded as having brought some women unprecedented access to the res publica litteraria, new ideas about the equality of the sexes are said to have had less impact in Germany. ${ }^{17}$ Some of the first women in England to see their translations in print - Margaret Roper, Mary Basset, the Cooke sisters - were the daughters and granddaughters of humanist scholars who had embraced the Italian model of the intellectual "household academy"; there was sympathy for

\footnotetext{
${ }^{15}$ For a comparative analysis of the situation in Britain and Germany see Stuart Gillespie, 'Vernacular Translations of Classical and Neo-Latin Writings in the European Renaissance: the Germanic Languages', in Harald Kittel etc. (eds.), Übersetzung - Translation - Traduction: Ein internationales Handbuch zur Übersetzungsforschung (3 vols., Berlin: de Gruyter, 2004-2011), II, pp. 1441-1447, at p. 1444.

${ }^{16}$ See Paul Mildonian, 'Translation and National Culture in the European Renaissance', in Harald Kittel etc. (eds.), Übersetzung - Translation - Traduction: Ein internationales Handbuch zur Übersetzungsforschung (3 vols., Berlin: de Gruyter, 2004-2011), II, pp. 1397-1410, at p. 1402-1405.

${ }^{17}$ See Ursula Hess, 'Lateinischer Dialog und gelehrte Partnerschaft: Frauen als humanistische Leitbilder in Deutschland (1500-1550)', in Gisela Brinker-Gabler (ed.), Deutsche Literatur von Frauen, (2 vols., Munich: Beck, 1988), I, pp. 113-148.
} 
these ideals in German humanist circles but a reluctance to put them into practice. ${ }^{18}$ To some extent this can be attributed to the fragmented nature of the German-speaking lands: the country lacked cultural centres akin to the Italian city states or the English capital where courts, universities and the print industry came together to create a dynamic and progressive atmosphere. $^{19}$

The course taken by the Reformation in Germany also had a powerful effect on gender ideology. Luther perpetuated the notion in his teachings that women were destined for marriage and childbearing; they had an important role to play within the home but were ultimately subordinate to the paterfamilias. This affected women in all spheres, including the most privileged. We find no translating queens or aristocrats in Germany (in contrast to the eight identified in England); women of the ruling classes were regarded primarily as "marriage objects" whose destiny was to bring about favourable alliances and produce healthy male heirs rather than spend hours with their books and translations in the manner of a Lady Margaret Beaufort (Beaufort, the mother of Henry VII, was involved in the purchase of books from all over Europe for various libraries, including Christ's College, Cambridge, which she founded; she became a patron of the early printers William Caxton, Wynkyn de Worde and Richard Pynson; and she sent two translations to the press, including the first

\footnotetext{
${ }^{18}$ See Hess, 'Lateinischer Dialog', p. 122. Ross posits that the model of the household academy best explains the rise of prominent, secular female intellectuals in early modern Europe (and discusses a number of translators): "The household academy made women intellectuals familiar and appealing figures in the literary landscape of sixteenth-century Italy and England. By 1580 there was an established tradition of learned women in both contexts who were neither nuns nor courtly patrons but the heirs of 'new men"' (Sarah Gwyneth Ross,
} The Birth of Feminism: Woman as Intellect in Renaissance Italy and England (Cambridge, MA: Harvard University Press, 2009), p. 93.

${ }^{19}$ Cf. Hess, 'Lateinischer Dialog', p. 130. 
translation into English of Book IV of Thomas a Kempis's seminal De imitatione Christi). ${ }^{20}$ The Reformation may have given some women the confidence to write literature, as they took on board Luther's idea about the priesthood of all believers, but it meant that many of their productions belonged to the same kinds of genres. If a woman turned to literature at all, she was almost invariably a Protestant, producing writing with a strong religious thrust, and hesitant to publish.

Women would not usually have been in a position to undertake translation anyway. Although both male and female literacy were greatly benefitted by the Reformation - at least in cities - girls generally received a rather rudimentary education which did not include the classical or modern languages. The aim of a girl's education was to prepare her for her future role as devout housewife and would have focused on basic literacy (German sufficient for reading the Bible) and religious instruction. Girls were taught in elementary schools or at home and were not exposed to the formal Latin-based curriculum of the Latin schools and universities. Boys who received a humanist education - a system which spread from Italy to the rest of Europe during the late fifteenth and sixteenth centuries and in which translation from the classical languages played a central role - would have been well set up for any later endeavours in this field: “Any diligent European (man, in most cases) who had followed such an educational programme must have been equipped with, at least, a thorough knowledge of Latin, and in some cases Greek, to enable him to embark on Greek-Latin translation, or at least use Latin translations of Greek works for vernacular translation. ${ }^{21}$ In Germany, Latin

\footnotetext{
${ }^{20}$ See Hosington, 'Women Translators', pp. 249-250. See also Barbara Becker-Cantarino, Der lange Weg zur Mündigkeit: Frau und Literatur (1500-1800) (Stuttgart: Metzler, 1987), pp. 202-204.

${ }^{21}$ John Denton, 'Translators and their Tools in the European Renaissance', in Übersetzung - TranslationTraduction, II, pp. 1415-1419, at p. 1416.
} 
dominated intellectual life to an extent we probably do not find elsewhere and remained the main second language translators worked with throughout the sixteenth century. ${ }^{22}$

Women would also not have had the same freedom to travel as their male counterparts; visits abroad had a formative influence on the careers of many translators. The typical humanist translator, for instance, made the "obligatory pilgrimage to Italy", completing his education in the New Learning and perfecting his knowledge of the classical languages. ${ }^{23}$ During the course of the century it became increasingly common for the sons of the wealthy to be sent on Grand Tours. We might think here of Prince Ludwig von AnhaltKöthen who embarked on his European travels at the tender age of seventeen, remaining abroad for five years and spending much of this time in Florence where in 1600 he became a member of the Accademia della Crusca. Prince Ludwig went on to found the first German language society, the Fruchtbringende Gesellschaft (Fruitbearing Society), modelled on the Accademia della Crusca, and translated over a dozen works into and out of French, Italian and German. ${ }^{24}$

Finally, women would not generally have had access to the networks of scholars, patrons and printers which gave rise to so many translation projects in this period. From the late fifteenth century, humanists often congregated in printing and university centres in the south which had close connections to Italy. The printing-shops of Johann Amerbach and Johann Froben in Basel, for example, became important meeting-places for travelling

\footnotetext{
${ }^{22}$ Werner Schwarz, 'The Theory of Translation in Sixteenth-Century Germany', Modern Language Review, 40 (1945), pp. 289-299, at p. 289.

${ }^{23}$ Erika Rummel, 'Ad fontes: German Humanists as Editors and Translators', in Max Reinhart (ed.), Early Modern German Literature 1350-1700 (Rochester, NY: Camden House, 2007), pp. 331-353, at pp. 332-333.

${ }^{24}$ See Gerhard Dünnhaupt, 'Die Übersetzungen Fürst Ludwigs von Anhalt-Köthen: Ein Beitrag zum 400. Geburtstag des Gründers der Fruchtbringenden Gesellschaft', Daphnis, 7 (1978), pp. 513-529.
} 
scholars and generated numerous collaborations; translators benefitted from the humanist vision of the printers and their extensive contacts in Basel and throughout Europe, from their crew of scholarly correctors and editors locally to their literary agents in Paris and London. ${ }^{25}$ In university towns such as Heidelberg and Strasbourg humanists formed sodalitates and encouraged each other to translate the classics. The Heidelberg circle was supported by the Count Palatine and his privy counsellor Johann von Dalberg who each commissioned a number of works: Johann Reuchlin, for instance, was employed for a time by the Count as librarian and tutor to his sons and at Dalberg's request turned a number of Greek texts into Latin and German. The Heidelberg translators who sent their work to the press appear to have been assisted by patrons too: Dietrich von Plenningen's translations of Sallust and Pliny the Younger were both published by Johann Weyssenburger in Landshut with eight-year privileges granted by Emperor Maximilian I's Imperial Senate. ${ }^{26}$

In the later part of the sixteenth century, as the print trade expanded and a market began to emerge for genres such as chivalric romances and farces, particularly translations from Latin and Italian, commercially-minded publishers called on translators to help them turn out new batches of titles for the biannual Frankfurt book fairs. ${ }^{27}$ Translations were published as a result of networks built up by men who could travel and move freely within the European publishing trade. For example, in 1569 the Frankfurt publishing firm Feyerabend launched a multi-volume German edition of the Spanish-Portuguese serial novel Amadis de Gaulla, already a bestseller in Spain, France and Italy, and over the next thirty

\footnotetext{
${ }^{25}$ Rummel, 'Ad fontes', p. 332 and pp. 340-343.

${ }^{26}$ Lawrence S. Thompson, 'German Translations of the Classics between 1450 and 1550', Journal of English and Germanic Philology, 42 (1943), pp. 343-363, at pp. 346-347; Karl Hartfelder, Deutsche Uebersetzungen klassischer Schriftsteller aus dem Heidelberger Humanistenkreis (Heidelberg: Mohr, 1884), pp. 3-13.

${ }^{27}$ See Füssel, 'Early Modern German Printing’, pp. 240-243.
} 
years employed a team of translators to supply copy of the French source texts. Feyerabend may have obtained the source texts from the Antwerp typographer Christophe Plantin, who came to Frankfurt twice a year for the book fair and had ample dealings with the Feyerabend firm, and would have parcelled these out directly to Johann Fischart, Conrad Egenberger and his other jobbing translators. ${ }^{28}$

The language societies set up in the early seventeenth century were largely male-only networks too. Members were encouraged to work on translations as part of collective efforts to cultivate the German language and German literature; there was a culture of collaboration within the societies which meant members suggested projects to each other, circulated their work-in-progress and helped each other to find outlets for publication. As Head of the Fruchtbringende Gesellschaft, for example, Prince Ludwig insisted that members send him their manuscripts and he and others revised and proofread translations to ensure they could stand as models of pure and elegant German. Many translations were then sent directly to Prince Ludwig's own printing press in Köthen. Translators within the Fruchtbringende Gesellschaft were fortunate in having direct access to this press as the Prince had the financial means to run it as an ideological as much as commercial enterprise. He nevertheless invested significant energy into all aspects of printing and distribution - from sending his Works Inspector Johann Le Clerq to Frankfurt and Leipzig in the early years to organise premises for selling books himself to establishing a more sophisticated arrangement with local dealers in the early $1620 \mathrm{~s}$ - in order to ensure that Society publications were disseminated as widely as possible. ${ }^{29}$

\footnotetext{
${ }^{28}$ See Hilkert Weddige, Die 'Historien vom Amadis auss Franckreich': Dokumentarische Grundlegung zur Entstehung und Rezeption (Wiesbaden: Steiner, 1975), pp. 29-137.

${ }^{29}$ See Gerhard Dünnhaupt, 'Die Fürstliche Druckerei zu Köthen: Ein Beitrag zum 400. Geburtstage des Fürsten Ludwig von Anhalt-Köthen (1579-1650)', Archiv für Geschichte des Buchwesens, 20 (1979), pp. 896-950;
} 
And so it is unlikely that we will uncover a tradition of forgotten women producing and publishing translations in Germany throughout this period. Of course one wonders whether female translators may yet emerge given that we still know comparatively little about literary women in Germany compared to their sisters in more thoroughly researched contexts such as England. It is possible that there are manuscripts waiting to be discovered such as the manuscript produced c. 1500 by the Catholic nuns Apollonia Tucher and Caritas Pirckheimer which contains a German version of a Latin history of their convent. ${ }^{30} \mathrm{We}$ should not dismiss such productions too readily: manuscript and print of course existed sideby-side and manuscript works could circulate widely and assume their own significance. Nevertheless, recent 'recovery' work in the archives points to religious poets rather than to translators. ${ }^{31}$ For now we must conclude that for most of this period women either did not translate or that they did not publish their translations.

\section{Female translators of the $1620 \mathrm{~s}$}

Klaus Conermann, 'Die fürstliche Offizin zu Köthen: Druckerei, Verlagswesen und Buchhandel im Dienste des Ratichianismus und der Fruchtbringenden Gesellschaft (1618-1644/50)', Wolfenbütteler Barock-Nachrichten, 24 (1994), pp. 121-178.

${ }^{30}$ See Lotte Kurras and Franz Machilek, Caritas Pirckheimer 1467-1532: Eine Ausstellung der katholischen Stadtkirche Nürnberg, Kaiserburg Nürnberg, 26. Juni-8. August 1982 (Munich: Prestel, 1982), pp. 90-102. Earlier women who produced manuscript translations are Anna von Pferingerim (d. 1451), a Bavarian abbess, who rendered the Vita Hilarii from Latin into German, and the noblewomen Elisabeth von Nassau-Saarbrücken (ca.1395-1456) and Eleonore of Austria (1433-1480) who produced German versions of French courtly romances.

${ }^{31}$ See e.g. Albrecht Classen, Late-Medieval German Women's Poetry (Cambridge: Brewer, 2004), especially pp. 1-22, and 113-154. 
In the early decades of the seventeenth century the situation began to change and for some women there were new opportunities to become involved in intellectual life. It seems that Renaissance ideas were starting to have a more pervasive effect: scholars and noblemen travelling abroad had seen the thriving national culture of Italy or France or the Netherlands and returned home intent on bringing about a cultural renaissance on German soil. The movement to promote German-language culture, given new impetus by the founding of the language societies and the publication of Martin Opitz's programmatic rulebook for vernacular literature Buch von der Deutschen Poeterey (Book of German Poetics) (1624), meant that the intellectual tradition gradually became more accessible to those without Latin. There were also some influential men who saw the advantages of supporting women's education and allowing them access to the republic of letters: women could help to elevate German society by partaking in conversatione civile, that Renaissance concept they had been so struck by in Italy and France. Prince Ludwig, for one, was keen to involve female family members as far as possible in his projects: he sent them books and let them roam his library at the Köthen court, he provided guidance as they made their first attempts to turn German into Italian or Italian into German, he helped them to set up their own all-female language societies, the Noble Académie des Loyales a.k.a. Güldene Palm-Orden (Order of the Golden Palm) (1617-c.1640) and the Tugendliche Gesellschaft (Society of Virtue) (1619-52), and he allowed a number to take part unofficially in the programme of the Fruchtbringende Gesellschaft.

Despite this change in circumstances, few women still took the step of publishing their work. Women in the Académie des Loyales and Tugendliche Gesellschaft, for example, produced a number of translations but rarely sent their manuscripts to the press. Generally speaking, they may have been held back by a sense that they were overstepping the bounds of 
propriety and that their activities were condonable only within private court circles. ${ }^{32}$ Yet in the 1620 s three translations by women appear in print; these are quite possibly the first translations by German women to be published during their lifetime. We shall see that in these three cases the women's publications cannot be categorised as 'feminine' in any obvious way but have much in common with those of their male contemporaries. We shall see that they too seized the opportunities presented by print to make significant contributions to intellectual and political developments.

The first two of these translations may appear at first sight to be rather humble efforts. There is a translation of Pierre Du Moulin's Héraclite, ou, De la vanité et misère de la vie humaine (1609) (Heraclitus; or On the Vanity and Misery of Human Life), a short religious treatise urging believers to save themselves from worldly sin through faith, by the noblewoman Eleonora Maria von Anhalt-Bernburg:

\section{Schatzkämmerlein Heilsamer Zuneigungen: Welches in dreissig Betrachtungen begriffen / und mit etlichen hierzu gehörigen Reimen vermehret worden / Durch Herrn von Rivery gestellet / und an jetzo in Teutsche Sprache übergesetzt (Cöthen: Fürstliche Druckerei, 1623). Contains: Heraclitus oder Betrachtung der Eitelkeit und Elend des Menschlichen Lebens / Aus dem Teutsche Sprach versetzt}

And there is Maria Fabry's German version of her own earlier Petit Extraict de la saincte Escriture (Short Extracts from the Holy Scriptures) (ca. 1621):

\footnotetext{
${ }^{32}$ See Klaus Conermann, 'Die Tugendliche Gesellschaft und ihr Verhältnis zur Fruchtbringenden Gesellschaft: Sittenzucht, Gesellschaftsidee und Akademiegedanke zwischen Renaissance und Aufklärung', Daphnis, 17 (1988), pp. 513-626, at p. 540.
} 
Trewhertziger Wegweiser, zu einem christenlichen gottseligen Leben, und Absterben, auß heiliger Schrifft zusammen gezogen / durch Maria Fabry / Jeztund aber auß dem Frantzösischen corrigierten Original Teutsch ubersetzt (Basel: Wagner, 1626)

The translations do not seem to stand out from the productions of German women since the Reformation: the titles suggest that this is edifying religious matter of the type to which women were limited in the past. Moreover, in Anhalt-Bernburg's case at least, the female translator is invisible. Her Heraclitus is appended to a translation of a work of French moral philosophy Cabinet des saines affections (Cabinet of Healthy Sentiments) made by her brother's Hofmeister (one of the highest court officials) Hans Ernst von Börstel and is tucked away at the back of that book with no mention of her name, let alone any paratextual material such as a translator's preface. We know that she was responsible for the translation only from notes made by her brother in his diary. ${ }^{33}$

However, when we place these translations in a broader context we begin to see the boldness and significance of their undertakings. As in England, religious translation was not a domain specifically reserved for women and cannot be assumed to be a merely respectable and innocuous occupation in this age of confessionalisation. Anhalt-Bernburg's Heraclitus, for instance, must be seen as part of the wider reception of Pierre Du Moulin in Germany and Europe. Moulin was one of the most popular Protestant writers of the age: he became a pastor

\footnotetext{
${ }^{33}$ See Klaus Conermann, 'Editionsdesiderate: Die Werke der Fürsten Ludwig und Christian II. von Anhalt im Kontext der Akademiearbeiten der Fruchtbringenden Gesellschaft', in Hans-Gert Roloff (ed.), Editionsdesiderate der Frühen Neuzeit: Beiträge zur Tagung der Kommission für die Edition von Texten der Frühen Neuzeit (2 vols., Amsterdam: Rodopi, 1997), I, pp. 390-490, at p. 396.
} 
of the Huguenot church in Paris in 1598 and over the next sixty years established himself as the "premier spokesman" for French Protestantism. ${ }^{34}$ He was the author of over 100 polemical and devotional treatises which went through numerous editions in many different European languages. ${ }^{35}$ Indeed, there were at least four other German translations of Héraclite in the first half of the seventeenth century alone: three give the names of the translators on the title-pages, and they are all male, while the fourth was published anonymously like AnhaltBernburg's. Against the backdrop of the Thirty Years' War, it appears that Moulin was coopted by Protestant translators in Germany in support of the Protestant camp. Even an apparently devotional tract by the passionately anti-Catholic French firebrand was going to be forthright and potentially incendiary-Héraclite is full of visions of lust and greed and corruption with barbs directed specifically at Rome ('Au pays dont nous viennent les Decrets $\&$ qui reigle auiourd'huy la religion, les bordeaux y sont publics, la Sodomie y est tournee en coustume: \& les decisions des doutes de la Foy se sorgent parmy ceste corruption')—and one male translator, the Lutheran legal scholar Christoph Besold, warns in the first line of his preface of the censure Moulin's work will inevitably invite. ${ }^{36}$

\footnotetext{
${ }^{34}$ Brian G. Armstrong, 'The Changing Face of French Protestantism: The Influence of Pierre Du Moulin', in Robert V. Schnucker (ed.), Calviniana: Ideas and Influence of John Calvin (Kirksville, Missouri: Sixteenth Century Journal Publishers, 1988), pp. 131-149, at p. 136.

${ }^{35}$ See Brian G. Armstrong, Bibliographia Molincei: An Alphabetical, Chronological and Descriptive Bibliography of the Works of Pierre Du Moulin (1568-1658) (Geneva: Droz, 1997).

${ }^{36}$ Pierre Du Moulin, Héraclite, ou, De la vanité et misère de la vie humaine (Paris: Villain, 1609). English translation: 'In the Countrey from whence the Decretals come, (and which rules Religion at this day) Bawdyhouses are common, and Sodomy grown a fashion, and yet the decision of the doubts of Faith must be coyned in the place of all this villany'. Heraclitus, or Mans Looking-glass and Survey of Life, trans. Sir H. L'Estr. [Hamon L'Estrange] (London: Seile, 1652), p. 90. See also Heraclitus oder Spiegel der weltlichen Eytelkeit und ellendes menschlichen Lebens, trans. Christoph Besold (Strasbourg: Zetzner, 1627), n. p.
} 
Anhalt-Bernburg was surely contributing to what her closest associates would have considered to be an urgent political cause. She hailed from the Protestant nobility and her work was closely tied up with her family's political-confessional agenda. She was the daughter of Christian I von Anhalt-Bernburg and niece of Ludwig von Anhalt-KöthenReformed princes who were deeply involved in the political struggles of the Reich in the early decades of the seventeenth century. Ludwig's Fruchtbringende Gesellschaft, for example, may have been established ultimately for political reasons. ${ }^{37}$ It began as a largely Protestant organisation - in the first decade or so of its existence it admitted 108 Lutherans, eight-five Calvinists and three Catholics - and promoted Sprachpflege (cultivation of the language) in order to foster unity and peace among the German people; German should be refined so that it could be adopted as the national language, and this implied a rejection of Latin as the language of the Catholics and imperialists. The Society gained a more pressing political function in the $1620 \mathrm{~s}$ in the wake of a series of Protestant political and military defeats and seems to have been conceived in this period as a brother organisation to the Teutscher Friedbund (German Peace League), which was founded by Prince Ludwig's nephew and fellow Fruitbearer Wilhelm IV von Sachsen-Weimar, i.e. an alliance of the Protestant elites which would help to counter the current threat from Habsburg forces to the central German states. It seems that the Society aimed to bring the officer class together with aristocrats and encourage them to rally behind shared ideals in order to prepare them mentally

\footnotetext{
${ }^{37}$ The links between the Fruchtbringende Gesellschaft and contemporary politics are relatively underexplored but I am building here on interpretations advanced recently by historians: Georg Schmidt, 'Die Anfänge der Fruchtbringenden Gesellschaft als politisch motivierte Sammlungsbewegung und höfische Akademie', in Die Fruchtbringer - eine Teutschhertzige Gesellschaft, ed. Klaus Manger (Heidelberg: Winter, 1999), pp. 5-37 and Joachim Whaley, Germany and the Holy Roman Empire, (2 vols., Oxford: Oxford University Press, 2012), I,
} pp. $462-474$. 
to stand up to the oppressors of the German nation. Anhalt-Bernburg was in sympathy with the patriotic efforts being driven by the Anhalt and Saxon courts and was one of the early members of both the Académie des Loyales and the Tugendliche Gesellschaft.

Her Héraclite translation was part of the publishing programme of the Fruchtbringende Gesellschaft. It was issued by the Köthen press and printed in one of the volumes of a polyglot edition of the Cabinet des saines affections which was put together by members of the Society (her brother's Hofmeister, Hans Ernst von Börstel, had joined the Fruchtbringende Gesellschaft in 1621). It stands alongside a large number of translations produced by Fruitbearers which aimed to serve as exemplary models of vernacular writing and at the same time advance religious and political reform. This programme was ostensibly irenic and non-partisan - the Society was meant to unite adherents of different confessions to bring about a civilised peace across the nation - but members were inevitably drawn to Protestant and particularly to Reformed writers. And so Anhalt-Bernburg's translation can be seen as an early example of a type of literature which would be increasingly favoured by her colleagues; by the 1640s devotional literature would become an explicit focus of the Köthen press and publications included a translation by her brother Christian II von Anhalt-Bernburg of De la persévérance des Saincts (On the Perseverance of Saints) by the Reformed minister and publicist Charles Drelincourt (1641) and a translation by Prince Ludwig of Le Sage Vieillard (The Wise Old Man) by Simon Goulart, a Reformed theologian who had been a pastor in the Calvinist stronghold of Geneva (1643). By turning to Moulin, Anhalt-Bernburg aligns herself with the ambitions of the Society and becomes an active agent in wider political developments. The fact that she remains invisible to the public should not concern us too much here or be linked necessarily to her position as a woman. It was still common for the nobility to withhold their names from publications as literature was not deemed an entirely respectable aristocratic pastime (none of Ludwig's works appeared under his own 
name) and many Köthen publications appeared anonymously or merely stated that they had been printed under the auspices of the Fruchtbringende Gesellschaft. Her work was clearly valued as an important contribution to the Society's programme and the volume containing her translation was reissued by the Köthen press in 1641 .

As for Fabry, her work must also be viewed in the context of local conditions. Her dual-language edition of a devotional tract was in many respects a typical product of the Basel book trade: "During the second part of the sixteenth century, the frontier cities of Antwerp, Strasbourg, and Basel established themselves as major centres of evangelical publishing, distributing books published in all the European vernaculars." ${ }^{\text {38 }}$ The Basel printing industry had a strong Francophone presence and sold many books to the French territories; by the early seventeenth century the market for German-language works expanded and printers were often keen to re-issue works which had proven to be commercially successful in French. ${ }^{39}$ Fabry was part of these Franco-German family and business networks: she was a French native speaker and daughter of a printer (her father Eustache Colinet was a printer in Geneva who had probably emigrated from Lyon) and in 1587 she married the German-born surgeon and publicist Wilhelm Fabry who had extensive contacts in the print industry. Her work sits comfortably among the publications of fellow Francophones in Basel at this time, who tended to be Protestants who had fled religious persecution in France and by the time the French congregation had been given permanent premises in Basel in 1614 were concerned primarily with exercising their faith in a calm and tolerant manner.

\footnotetext{
${ }^{38}$ Simona Munari, ‘Translation, Re-Writing and Censorship during the Counter-Reformation’, in José María Fernández and Edward Wilson Lee (eds.), Translation and the Book Trade in Early Modern Europe (Cambridge: Cambridge University Press, 2015), pp. 185-200, at p. 191.

${ }^{39}$ Peter G. Bietenholz, Basle and France in the Sixteenth Century: The Basle Humanists and Printers in Their Contacts with Francophone Culture (Geneva: Droz, 1971).
} 
The French immigrant authors mostly avoided even anti-Lutheran comment and instead sent to the presses edifying literature of a Calvinist or Zwinglian bent. In fact, the publication of such works was typical of the Basel industry as a whole in these decades. In the early seventeenth century, the confessional debates raging elsewhere in the Empire found only a "modest echo" in this corner of the Swiss confederacy. ${ }^{40}$ Fabry's translation was published by Martin Wagner whose press focused on devotional-religious writing; between c.1620-1655 he issued over 150 titles in this vein. ${ }^{41}$

Fabry's productions were self-assured and innovative. Fabry and her husband worked closely together in the fields of medicine and religion (Fabry is probably best known today under the name Marie Colinet - for her work as a midwife and surgeon). The couple appear to have seen themselves on a mission to heal both the bodies and souls of their fellow mortals, and they published extensively on spiritual topics: apart from the Le Petit Recueil / Trewhertziger Wegweiser, Fabry published an 824-page Alphabet nouveau et chretien pour les jeunes apprentifs, qui d'oresenavant commenceront d'aller en l'escole du S. Esprit (New Christian Alphabet for Young Apprentices Who Desire Henceforth to Attend the School of the Holy Ghost) (1638). Fabry may have shared the convictions of her husband but she develops a distinctive voice and her writings can be regarded as avant-garde. She writes lengthy prefaces to her readers which underline her confidence in her undertakings and make little apology for the fact that she is a woman: she states that she has been driven by God to assist others and that her pen has been guided by the Holy Ghost, making her sound as if she is propagating a position we would associate with early Pietism. She has a vision of the ills of

\footnotetext{
${ }^{40}$ See Bietenholz, Basle and France, Chapter 3.

${ }^{41}$ Unfortunately, very little else is known about the Wagner firm. See the entry for Wagner in the 'Index Typographorum Editorumque Basiliensium': http://www.ub.unibas.ch/itb/druckerverleger/martin-wagner/ (accessed 1 July 2016).
} 
the world which she wants to heal through the "Seelen Arztney" (spiritual medicine) of the Holy Scriptures and she does not hesitate to write about issues - such as the current fashions for women which expose their breasts - which sound surprisingly modern. ${ }^{42}$

The third and final case belongs to quite another genre and is not the type of translation or publication we have been led to expect from a woman in Germany at all. It is the German version of a political pamphlet which had first appeared in Latin in 1619 under the title Oratio Paraenetica, De Auctoritate Regum Et Principium asserenda, \& bellorum causis in Europa and was penned by the controversial Catholic theologian Kaspar Schoppe (under the pseudonym Hermann Conrad, Freiherr von Friedenberg). The source text is addressed to the kings and princes of the Holy Roman Empire and discusses the causes of the current crisis in Europe, more specifically urging the Catholic Estates to defend themselves in the face of the Bohemian Revolt and the threat from the Protestant Netherlands. The translation appeared in 1620 and declares itself on the title-page to be by "Martha Salome à Belta":

Discordista. Sive Secundus Scioppius Hoc est: Oratio Paraenetica. Oder: Deß H. Römischen Reichs Feind / Und Newer Friedenstörer. Das ist: Ein Auffrührische ErinnerungsSermon: An alle Könige und Fürsten / wie Sie ihro Königliche Würden / und Fürstliche Hoheiten erhalten können? und den Von den Ursachen deß Europäischen heutigen Kriegs. Erstlich in Latein / unter einem gedichten Namen außgangen / unnd spargirt. Jetzt aber Dem Gemeinen Nutz / zu sonderlicher Warnung inns Teutsche gebracht: Von der Hoch WolEdlen / Ehrnviel Tugendreichen Frawen Martha Salome à Belta, ihres Vatterlandts eyfferige Liebhaberin. (Warnstatt: Judith Richterin, 1620)

\footnotetext{
${ }^{42}$ Cf. Eugène Olivier, 'Einige neue Mitteilungen über Fabry und seine Familie', trans. Wolfgang Wennig, Hildener Jahrbuch, 6 (1956), pp. 273-286.
} 
Moreover, in the same year there appeared a further pamphlet, authored by Belta, which refutes Schoppe's account and lays the blame for the war firmly on the papists and Jesuits:

\begin{abstract}
Militis togati Anatomia: Oder Böhmischer Warsager: welcher inn sechserlej Gesprächen / Augenscheinlich darthut und Erweist / das der jetzige Krieg, nicht von den Lutheranern oder Calvinisten / sondern von den Papisten und Jesuiten / vor vilen Jahren angesponnen / und an jetzo von ihnen zu wreck gerichtet worden / Was aber die Hauptsachen seyen / Davon Conferiren und discuriren, die Colloquenten fundamentaliter. Von der Hochwoledlen / Ehrenviel Tugendtreichen aus Hochverständigen Frawen / Martha Salome Von Belta / ihres Vatterlandts eyfferige Liebhaberin. Anstat einer Refutation dem Herimanno Cunrado in Friedenberg /auff sein Lermenblaserische Oration, ihrem Vatterlandt aber zum besten / zugeschickt. (Warnstat [sic.]: Judith Richterin, 1620)
\end{abstract}

Before going any further, we would do well to ask whether these publications really can be attributed to a woman called Martha Salome von Belta. The author has disappeared without trace: it seems that nothing is known of her beyond what can be gleaned from her published work. ${ }^{43}$ During the Thirty Years' War it was in fact common for pamphlets to be published anonymously or under pseudonyms. Writers may have feared the repercussions of

\footnotetext{
${ }^{43}$ See for instance the information about Belta provided in Christoph Hendreich, Pandectae Brandenburgicae (Berlin: Liebpert, 1699), p. 500, which forms the basis of the Belta entries in Gottlieb Sigmund Corvinus, Nutzbares, Galantes und curiöses Frauenzimmer-Lexikon (Leipzig: Gleditsch, 1715) and J. H. Zedler, Großes Vollständiges Universal-Lexikon aller Wissenschaften und Künste (Halle: Zedler, 1732-1754).
} 
censorship as Schmähschriften (defamatory writing) had been banned since the early days of printing. But given that small-format works were hard for the authorities to police, writers may sometimes have masked their identity for more playful reasons too, using the ruse in order to express rather than hide something. ${ }^{44}$ It is possible that "Belta", a man, assumed the unusual persona of a writing woman in order to stand out from his crowd of fellow pamphleteers. What is more, unlike most other publications of the seventeenth century, the pamphlets rarely gave the name of the printer either - businesses probably had more to fear from the censors - and we seem to be presented here with a false colophon. ${ }^{45}$ Our printer's name is female too: could this be a clue for the reader that the translator/author and printer were engaged in a game of camouflage ${ }^{46}$

We may indeed wonder whether a woman would have been in a position to pen such works. Authors of pamphlets were usually highly educated theologians or politicians or

\footnotetext{
${ }^{44}$ Esther-Beate Körber, 'Deutschsprachige Flugschriften des Dreißigjährigen Krieges 1618 bis 1629', Jahrbuch für Kommunikationsgeschichte, 3 (2001), pp. 1-47, at pp. 18-21. Emil Weller believes the name to be a pseudonym. See Emil Weller, Index Pseudonymorum: Wörterbuch der Pseudonymen oder Verzeichniss aller Autoren, die sich falscher Namen bedienten (Leipzig: Oehme, 1862), p. 43.

${ }^{45}$ See Emil Weller, Die falschen und fingierten Druckorte. Repertorium der seit Erfindung der Buchdruckerkunst unter falscher Firma erschienenen Schriften (Leipzig: Falcke \& Rössler, 1858), p. 13. See Urs B. Leu, “"Nuhu trit herfur o pfaltzischer Lew”: Eine unbekannte Flugschriftensammlung zum Dreißigjährigen Krieg in der Zentralbibliothek Zürich', Gutenberg-Jahrbuch, 84 (2009), pp. 289-306, at p. 293.

${ }^{46}$ There is perhaps a link between the stylisation of Belta as "Judith" in the dedicatory material in both works and the name of the printer "Judith Richterin"_-Judith being the Biblical heroine who saves her nation by decapitating the enemy general of the invading foreign forces. We should note, however, that seeing the name of a female printer on the title-page might not have struck readers as particularly remarkable as a number of women were active as printers in Renaissance Germany. See Heide Wunder, He is the Sun, She is the Moon:
} Women in Early Modern Germany, trans. Thomas Dunlap (Cambridge, Mass, and London: Harvard University Press, 1998), p. 92. 
scholars writing primarily for a similarly highly educated audience at the universities and courts. "Belta" is clearly aware of her intended readership and the conventions of the genre. For instance Discordista may be a translation into the vernacular but remains peppered with Latin words and phrases, the prose style typical of such pamphlets, while the Böhmischer Warsager makes use of a common device in being written as a set of dialogues between allegorical figures with names such as "Frechmut" (Mr. Impudent) "Ohnsorg” (Mr NoWorries) and "Angstmut” (Mr. Fearful). Belta seems to be moving effortlessly in a masculine domain.

It is difficult to draw any conclusions from the paratextual material either. The Discordista pamphlet includes at the end texts dedicated to Belta by authors who likewise cannot so far be traced: a Latin poem by one "Juliana Fänle" and a letter by "Johann Friedrich Donnerkeil". We may wonder if these are further fictions: a woman publishing neoLatin verse addressed to a fellow Latinate woman would be a rare occurrence indeed in Germany in the $1620 \mathrm{~s} .^{47}$ The poem and letter praise Belta for her learnedness and for taking up her pen in support of the fatherland but they shed little light on the enigmatic author. Indeed, Fänle's poem hinges on the idea of Belta's uniqueness, suggesting that her attributes are so man-like that she is at least an honorary man:

Rara avis in terris, alboq[ue] simillima corvo

Fœmina, quæ Latijs dedita literulis. [...]

Fœmina naturâ si non homo; tu mihi sexum

Fœmineum superas artibus, Ergo es homo. ${ }^{48}$

\footnotetext{
${ }^{47}$ See Stevenson, Women Latin Poets, pp. 336-347.

${ }^{48}$ Discordista. Sive Secundus Scioppius Hoc est: Oratio Paraenetica... (Warnstatt: Richterin, 1620), n.p. English translation: "A woman devoted to literary activity in Latin is a rare bird in [our] lands, and most
} 
As for Donnerkeil, he gives the impression of having been involved in both the Discordista and Böhmischer Warsager projects: his letter to Belta gradually turns into an essay on Schoppe and the political situation and one is left wondering if "Belta" is merely an interesting framing device.

But of course it is possible that Martha Salome von Belta is the woman she claims to be. After all, not all pamphlet authors published anonymously or under pseudonyms. Schoppe himself is a case in point: his Classicum belli sacri (1619), which was nothing if not highly controversial (he calls for a holy war against the heretical, devil-worshipping Lutheran princes), had appeared under his own name. And if Belta acts likewise then we have here an extraordinary example of a woman using the opportunities presented by print to add her voice to the contemporary political debate.

For despite the risks, there was much demand from printers for this kind of material. By the early seventeenth century the industry had developed to such an extent that printers were learning how to capitalise on the new market for news and propaganda: news sheets and newspapers began to appear regularly during these years and printers were hungry for the pamphlets and flysheets which were becoming "an integral part of any political discourse".During the course of the century, some 13,590 pamphlets were published in the German-speaking countries, with a peak in production in the early years of the Thirty Years' War. $^{49}$

In sending her pamphlets to the press, Belta was entering a far-reaching and highly charged debate about the future of the German nation. She declares on the title-pages that she

\footnotetext{
like a white raven. [...] / A woman in nature if not a man; to me you surpass the feminine sex in skill; you are therefore a man". I am grateful to Dr. Elena Theodorakopoulos for providing the translation.

${ }^{49}$ Whaley, Germany and the Holy Roman Empire, pp. 569-570.
} 
has published as a "zealous lover of her fatherland" ("ihres Vatterlandts eyfferige Liebhaberin"): Schoppe's tract has been translated into German as a "warning" to the German people (“Dem Gemeinen Nutz / zu sonderlicher Warnung inns Teutsche gebracht”) and the Böhmischer Warsager has been written for "the good of the fatherland" ("ihrem Vatterlandt aber zum besten"). It has been argued that Belta is making typically female statements here-invoking duty to one's subjects was one of the ways in which women justified their publishing in early modern Germany. ${ }^{50}$ But Belta is in fact adopting a rhetoric which was by now commonplace among (Protestant) contemporaries writing about the Reich and she positions herself within this discourse by drawing on stock phrases found on the covers of many similar pamphlets, with many billed as "warnings" by "well-meaning German patriots". ${ }^{51}$ Where she seems to differ from earlier women writers is that she is speaking out as a member of a political community which is national rather than local (in the sixteenth century a few women declare that they are publishing their texts for the benefit of citizens in their hometown or the subjects of their state). And she does not baulk from taking on one of the figures at the centre of the political debate in the early years of the war. Among the many hundreds of political pamphlets which appeared during these years, Schoppe's achieved a particular notoriety, were frequently reprinted in Latin and German, and spawned numerous tracts in response. She was not alone in alighting on the Oratio Paraenetica: at

\footnotetext{
${ }^{50}$ Merry Wiesner-Hanks, 'Kinder, Kirche, Landeskinder: Women Defend their Publishing in Early Modern Germany', in Robin B. Barnes etc. (eds.), Habent sua fata libelli-Books have their own Destiny: Essays in Honor of Robert V. Schnucker (Kirksville, MI: Thomas Jefferson University Press, 1998), pp. 143-152, at pp. $150-151$.

${ }^{51}$ See Whaley, Germany and the Holy Roman Empire, p. 471.
} 
least two other German translations were published in the same year. ${ }^{52}$ Belta adopts a clear position within this debate: she may be helping to disseminate Schoppe's work but the paratexts make explicit how she intends him to be received, i.e. she wants to make her compatriots aware of his dangerous ideas before providing her own passionate counterarguments in her second tract. The title-pages tell readers that the Discordista is a "seditious sermon" ("Ein Auffrührische ErinnerungsSermon”) by "an enemy of the Holy Roman Empire and new infringer of the peace" ("Deß H. Römischen Reichs Feind / Und Newer Friedenstörer"), and the Böhmischer Warsager is in effect a "refutation" ("Refutation") of his "rabble-rousing oration" ("Lermenblaserische Oration”). While Schoppe publishes his invectives in Latin, Belta chose to translate his work into German and to write herself in German, seemingly in order to bring the political debate to a readership beyond elite university and court circles; and indeed it has been shown that pamphlets such as these would have been read or listened to by thousands or even tens of thousands of people and had a significant influence on seventeenth-century political culture. ${ }^{53}$

${ }^{52}$ Wolmeinende Erinnerung Von Behauptung deß König und Fürsten Standts, auch Ursachen der Kriege in Europa: An die Könige, und Fürsten, in Lateinischer Sprach unlängst außgangen; Anjetzo aber dem gemeinen Mann zu gutem, auch in die Teutsche ubersetzt / Durch Herman Conraden Freyherrn zu Friedenberg, Rittern, unnd Comitem Palatinum (n. p.: 1620) and Ein kurtze und Trewhertzige vermahnung An alle König/ Fürsten und Potentaten/ wie dieselben bey ihrer authoritet, hochheit und wolstandt zuerhalten/Und von den Ursachen der jetzigen gefährlichen Kriegßempörungen/so in Europa entstanden: Welche...Herr Herman Conrad/in Fridenburg...Den Königen und Fürsten in besagtem Europa...zugesandt hat. Anjetzt aber durch einen eyffrigen Christen ...auß Lateinischer/ in unser Teutsche Sprach...versetzt/ und Erstlich in Böhaim Truckt (n. p.: 1620).

${ }^{53}$ See Georg Schmidt, 'Das Reich und Europa in deutschsprachigen Flugschriften: Überlegungen zur räsonierenden Öffentlichkeit und politischen Kultur im 17. Jahrhundert', in Klaus Bußmann and Elke Anna Werner (eds.), Europa im 17. Jahrhundert: Ein politischer Mythos und seine Bilder (Stuttgart: Steiner, 2004), pp. 119-148. 
The examples of Anhalt-Bernburg, Fabry and Belta demonstrate that there was indeed a tradition of female translators in Germany in the long sixteenth century, even if this has been up to now all but hidden from view. We have been able to trace the beginnings of this tradition to the 1620 s and seen that there were various historical and sociological reasons why women first published translations later in Germany than elsewhere in Europe. This investigation into some of the earliest female translators in Germany opens up new perspectives on the history of translation and culture. First, it challenges standard accounts of German literary history: uncovering the work of forgotten female translators shows us that women's literary productions in this period were more varied, bolder and more innovative than usually assumed. Second, we are able to gain important insights into questions around gender and translation. For much of the long sixteenth century, women in Germany may have been on the margins of cultural life and generally expected to remain silent, but they did not then turn to translation as a "degraded" and thus appropriately feminine activity. When they began to publish translations, their work is comparable in many ways to that of their male contemporaries. A handful of privileged women at least were able to engage in intellectual pursuits alongside their male colleagues and exploited their contacts in the print industry to become active agents in political and religious discourse. Finally, the research presented here helps to expand our knowledge of translation and the book trade in early modern Europe. The examples of Anhalt-Bernburg, Fabry and Belta add new perspectives to the interpretive challenges emerging in other chapters in this volume. Thus, for example, the case of AnhaltBernburg points up the perennial matter of invisibility "on the page"; the case of Fabry highlights the significance of the commercial book trade in early modern Europe in its 
relevance to translators and translation; and the case of Belta - related to that of AnhaltBernburg - foregrounds the theme of "dissemblance" as it relates to claims of textual authority. These three remarkable case-studies suggest that more research along these linesfocusing on men as well as women in the German-speaking lands - will prove productive and will help to draw attention to the frequently neglected part played by Germany in the history of European Renaissance culture. 


\section{BIBLIOGRAPHY}

\section{Primary (printed only)}

'Eloge de Mademoiselle 1'Héritier', Journal des Sçavans (1734), pp. 832-836

A briefe of the art of rhetorique Containing in substance all that Aristotle hath written in his three bookes of that subject, except onely what is not applicable to the English tongue

(London: Tho. Cotes, for Andrew Crook, [1637]), USTC 3019242

Achilles shield Translated as the other seuen bookes of Homer, out of his eighteenth booke of Iliades (London: John Windet, 1598), USTC 513690

Agüero, Cristóbal de, Misceláneo Espiritual en el idioma Zapoteco (Mexico City: Francisco Rodríguez Lupercio, 1666)

Antoninus of Florence, Summa theologica (Verona: Agostino Carattoni, 1790)

Aquinas, Thomas, Summa Theologiae (Rome: Marietti, 1948)

Ariosto, Ludovico, Orlando Furioso in English heroical verse, by John Harington (London: Richard Field, 1591), USTC 511733

Aristotle, Rhetoric, trans. W. Rhys Roberts (New York: Dover, 2004)

Ascham, Roger, The Scholemaster (London: John Daye, 1570), USTC 507056

Bautista Viseo, Juan, Advertencias para los confessores de los naturales (Tlatilulco:

Melchior Ocharte, 1600), USTC 344958

Bautista Viseo, Juan, Sermonario en Lengua mexicana (Mexico City: Casa de Diego Lopez Daualos, 1606)

Bembo, Pietro, Prose di m. Pietro Bembo nelle quali si ragiona della volgar lingua scritte al cardinale de Medici che poi fu creato a sommo pontefice et detto papa Clemente settimo divise in tre libri (Florence: Torrentino, 1548-49), USTC 813383

Biblia the Byble, that is, the holy Scrypture of the Olde and New Testament, faithfully translated in to Englyshe (Southwark: J. Nycolson, 1535)

Boccaccio, Giovanni, Genealogie deorum gentilium libri, ed. Vincenzo Romano (2 vols., Bari: Laterza, 1951)

Bornstein, Diane (ed.), Distaves and Dames: Renaissance Treatises For and About Women (Delmar NY: Scholars' Facsimiles \& Reprints, 1978)

Brandt, Sebastian, Narrenschiff (Ship of Fools) (Basel: Johan Bergmann, 1494), USTC 743644

Burgoa, Francisco de, Geográfica descripción. 2 vols (Mexico City: Editorial Porrúa, [1674] 1989)

Burnett, Charles, 'The Translator as an Authority', in Pieter De Leemans and Michèle Goyens, The Medieval Translator. Traduire au Moyen Age, vols. 1- (Turnhout: Brepols, 2016), XVI, pp. 53-67 
Carrillo Cázares, Alberto (ed.), Manuscritos del concilio tercero provincial mexicano (1585)

(5 vols., Guadalajara: Colegio de Michoacán-Universidad Pontifica de México, 2011)

Casas, Bartolomé de las, Apologética historia sumaria (Mexico City: UNAM, 1967)

Cicero, Marcus Tullius Ciceroes thre bokes of duties to Marcus his sonne, turned out of latine into english, by Nicholas Grimalde (London: Tottel, 1556), USTC 505294

Cicero, On Invention; Best Kind of Orator; Topics, trans. H. M. Hubbell (Cambridge MA: Harvard University Press, 2014)

Cicero, On the Orator, trans. E. W. Sutton, (2 vols., Cambridge MA: Harvard University Press, 2014)

Cicero, Philippica seconda . . . tradotta in volgare per m. Giovanni Giustiniano (Venice: Venturino Ruffinelli, 1538), USTC 822216

Cicero, Rhetorica Ad Herennium trans. H. Caplan (Cambridge MA: Harvard University Press, 2014)

Cicero, Those fyue questions, which Marke Tullye Cicero disputed in his manor of

Tusculanum . . Englished by John Dolman (London: Thomas Marshe, 1561), USTC 505856

Cooke Bacon, Anne, Apology or Answer in Defence of The Church Of England, ed.

(London: MHRA, 2015)

Córdova, Juan de, Arte en lengua zapoteca (Mexico City: Pedro Balli, 1578), USTC 344117

Córdova, Juan de, Vocabulario en lengua Çapoteca (Mexico City: Pedro de Ocharte and Antonio Ricardo, 1578), USTC 344115

Corvinus, Gottlieb Sigmund, Nutzbares, Galantes und curiöses Frauenzimmer-Lexikon (Leipzig: Gleditsch, 1715)

Day, John, The English Secretary, or Methode of writing of Epistles and Letters . . Now newly revised and in many parts corrected and amended (London: P. S. for C. Burbie, 1599), USTC 513931

Diccionario coloquios, o, dialogos en quatro lenguas, flamenco, frances, español y italiano .

.. Obra muy provechosa para todos mercaderes y otros de qualquier estado que sean (Amsterdam: C. Nicolas, 1580)

Die Schön Magelona: Ein fast lustige vnd kurtzweylige Histori vonn der schönen Magelona (Hildesheim and New York: Georg Olms, 1975)

Discordista. Sive Secundus Scioppius Hoc est: Oratio Paraenetica... (Warnstatt: Richterin, 1620), n.p.

Dodoens, Rembert, Niewe Herball, or Historie of Plantes (Antwerp: Hendrik van der Loe ven. Gerardus Dewes (London), 1578), USTC 406398

Dominican Order, Doctrina Christiana en le[n] gua española y mexicana (Mexico City: Juan Pablos, [1548] 1550), USTC 344124

Du Moulin, Pierre, Héraclite, ou, De la vanité et misère de la vie humaine (Paris: Villain, 1609)

Ein kurtze und Trewhertzige vermahnung An alle König/Fürsten und Potentaten/ wie dieselben bey ihrer authoritet, hochheit und wolstandt zuerhalten/Und von den Ursachen der jetzigen gefährlichen Kriegßempörungen/ so in Europa entstanden: Welche...Herr Herman Conrad/in Fridenburg...Den Königen und Fürsten in besagtem Europa ...zugesandt hat. 
Anjetzt aber durch einen eyffrigen Christen...auß Lateinischer/ in unser Teutsche Sprach...versetzt/ und Erstlich in Böhaim Truckt (n. p.: 1620)

Erasmus, Desiderius, A deuoute treatise vpon the Pater noster (London: Thomas Berthelet, ca. 1525), USTC 501942

Euclides, I quindici libri degli elementi di Euclide, di greco tradotti in lingua thoscana per Angelo Caiani (Rome: Antonio Blado, 1545)

Feria, Pedro de, 'Relación que hace el obispo de Chiapas', Anales del Museo Nacional de México 6 (1899), pp. 481-487

Feria, Pedro de, Doctrina christiana en lengua castellana y çapoteca (Mexico City: Pedro Ocharte, 1567), USTC 344087

Florio, John, Florio. His firste Fruites, which yeelde familiar speech, merie Proverbes, wittie Sentences, and golden sayings (London: Thomas Dawson for Thomas Woodcock, 1578), USTC 508538

Florio, John, Florios Second Frutes, To be gathered of twelve Trees, of divers but delightsome tastes to the tongues of Italians and Englishmen (London: Thomas Orwin for Thomas Woodcock, 1591), USTC 511810

Fouquart de Cambrai?, The Gospelles of Dystaues (London: Wynkyn de Worde, 1510), USTC 501164

Furió y Ceriol, Federio, Il concilio, et consiglieri del principe (Venice: Francesco Bindoni, 1560), USTC 831192

Geneologia de gli dei. I quindeci libri sopra la origine et discendenza di tutti gli dei de' gentili: con la sposizione \& sensi allegorici delle favole \& con la dichiaratione dell'historie appartenenti a detta materia. Aggiuntavi la vita del Boccaccio con le tavole d'i capi \& di tutte le cose degne di memoria che nella presente fatica si contengono (Venice: Comin da Trino for Andrea Arrivabene, 1547), USTC 814827

Gheeraert, Tony (ed.), Contes merveilleux: Perrault, Fénelon, Mailly, Préchac, Choisy et Anonymes (Paris: Honoré Champion, 2005)

Guazzo, Stefano, The ciuile conuersation of M. Steeuen Guazzo written first in Italian, and nowe translated out of French by George Pettie (London: R. Watkins, 1581), USTC 509295

Hawes, Stephen, The Boke Called the Example of Vertu (London: Wynken de Worde, 1509), USTC 516164

Hawes, Stephen, The Pastime of Pleasure, ed. William Edward Mead (London: Early English Text Society, 1928)

Hawes, Stephen, The Works of Stephen Hawes, ed. Sprang, Frank J. (Delmar NY: Scholars' Facsimiles \& Reprints, 1975)

Hendreich, Christoph, Pandectae Brandenburgicae (Berlin: Liebpert, 1699)

Heraclitus oder Spiegel der weltlichen Eytelkeit und ellendes menschlichen Lebens, trans. Christoph Besold (Strasbourg: Zetzner, 1627)

Heraclitus, or Mans Looking-glass and Survey of Life, trans. Sir H. L'Estr. [Hamon L'Estrange] (London: Seile, 1652)

Herodotus, Delle guerre de' Greci et de' Persi (Venice: Giovanni Antonio Nicolini da Sabbio for Melchior Sessa, 1533), USTC 835665 
Hollanda, Francisco de, Da Pintura Antiga, ed. Angel González García Lisbon (Lisbon: Imprensa Nacional-Casa da Moeda, 1984)

Hollanda, Francisco de, Da Pintura Antiga, ed. José da Felicidade Alves (Lisbon: Livros Horizonte, 1984)

Hollanda, Francisco de, On Antique Painting, ed. and trans. Alice Sedgwick Wohl (University Park, PA.: Pennsylvania State University Press, 2013)

Homer, Seauen bookes of the Iliades of Homere, prince of poets, translated according to the Greeke (London: John Windet, 1598), USTC 513689

Horace, Horace his arte of poetrie, [E]pistles and Satyrs Englished and to the Earle of Ormounte by Tho. Drant addressed (London: Thomas Marshe, 1567), USTC 506653

Horace, Odes of Horace . . Selected and Translated by Sir T. H. (London: W. Lee, 1625)

Il Nuovo Testamento di Christo Giesù Signore, et Salvatore nostro, di greco novamente tradotto in lingua toscana, per Antonio Brucioli (Venice: Lucantonio Giunta, 1532), USTC 802599

Ioscrates, Oratione d'Isocrate a Demonico . . tradotta da Madonna Chiara Matraini (Florence: Lorenzo Torrentino, 1556), USTC 836636

Isocrates, La prima oratione d'Isocrate a Demonico, tradotta dal greco idioma nel Italico (Venice: [Comin da Trino for] Stefano Alessi and Giovanni Battista Bertacagno, 1548), USTC 836633

Justinus, Marcus Junianus, Thabridgment of the histories of Trogus Pompeius, collected and wrytten in the Laten tonge, by the famous historiographer Iustine, and translated into English by Arthur Goldyng (London: Thomas Marshe, 1564), USTC 506270

León, Fray Martín de, Camino del Cielo en Lengua Mexicana (Mexico: Diego López Dávalos, 1611)

Levanto, Leonardo, Catecismo en lengua zapoteca (Puebla, Mexico City: Viuda de Miguel de Ortega, 1766)

Lhéritier, Marie-Jeanne, L'Apothéose de Mademoiselle de Scudéry (Paris : Moreau, 1702)

Lhéritier, Marie-Jeanne, L'Érudition enjouée, ou Nouvelles sçavantes, satyriques et galantes, écrite à une dame française qui est à Madrid (Paris: Ribou, 1703)

Lhéritier, Marie-Jeanne, La Tour ténébreuse et les jours lumineux (Paris: Barbin, 1705)

Lhéritier, Marie-Jeanne, Le Triomphe de Mme Des-Houlières, receue dixième muse au Parnasse (Paris: Claude Mazuel, 1694)

Lhéritier, Marie-Jeanne, Les Caprices du destin, ou Recueil d'histoires singulières et amusantes (Paris: Huart, 1717)

Lhéritier, Marie-Jeanne, Les épîtres hérö̈ques d'Ovide, traduites en vers françois, par Mlle L'Héritier (Paris: Brunet, 1732)

Lhéritier, Marie-Jeanne, Mémoires de M. L. D. D. N. contenant ce qui s'est passé de plus particulier en France pendant la guerre de Paris, jusquà la prison du cardinal de Retz, arrivée en 1652. Avec les différens caractères des personnes, qui ont eu part à cette guerre (Cologne, 1709)

Lhéritier, Marie-Jeanne, Euvres meslées . . de Mlle L'H** (Paris: Guignard, 1696) 
Livy, Le deche delle historie Romane di Tito Livio padovano, tradotte nuovamente nella lingua toscana, da Iacopo Nardi cittadino fiorentino (Venice: heirs of Lucantonio Giunta, 1540), USTC 838294

Lorenzana, Francisco Antonio, Concilios Provinciales Primero y Segundo, celebrados en la [...] ciudad de México [...] en los años de 1555 y 1565 (Mexico City: Imprenta del Superior Gobierno, 1769)

Marcellinus, Ammianus, Delle guerre de' romani. Tradotto per M. Remigio Fiorentino (Venice: Gabriele Giolito, 1550), USTC 809099

Marulić, Marko, Dialogo . . delle eccellenti virtù, et maravigliosi fatti di Hercole (Venice: [Niccolò Bascarini for] Stefano Alessi and Giovanni Battista Bertacagno, 1549), USTC 841265

Montaigne, Michel de, The essayes or morall, politike and millitarie discourses of Lord Michaell de Montaigne. . . The first booke (London: Edward Blount, 1603)

More, Thomas, The Workes of Sir Thomas More, Knyght . . written by him in the Englysh Tonge (London: John Cawood, John Waly and Richard Tottell, 1557), USTC 505459

Ortelius, Abraham, Synonymia geographica, sive Populorum, Regionum, Insularum, Urbium, Opidorum, Montium, Promontoriorum, Silvarum, Pontium, Marium, Sinuum, Lacuum, Paludum, Fluviorum, fontium, \&c. variae, pro auctorum traditionibus, saeculorum intervallis, Gentíumque idiomatis \& migrationibus, appellationes \& nomina. (Antwerp: Christophe Plantin, 1578), USTC 401762

Ortúñez de Calahorra, Diego, The Mirrour of Princely deedes and Knighthood . . Now newly Translated out of Spanish into our vulgar English tongue, by M[argaret] T[yler] (London: T. East, 1578), USTC 508627

Owen, John, Of the Divine Originall, Authority, self-evidencing Light, and Power of the Scriptures (Oxford: Henry Hall, 1659)

Pacheco de Silva, Francisco, Doctrina Christiana en lengua Zapoteca Nexitza (Mexico City: Francisco Sánchez, 1687)

Peacham, Henry, The Garden of Eloquence Conteining the most Excellent Ornaments, Exornations, Lightes, flowers, and formes of speech, commonly called the Figures of Rhetorike (London: Richard Field, 1593), USTC 512434

Petrarca, Francesco, Francesco Petrarca. Selected Letters, trans. Elaine Fantham (2 vols., Cambridge MA: Harvard University Press, 2017)

Petrarca, Francesco, Opera di m. Francesco Petrarca, De rimedi de l'una et l'altra fortuna, ad Azone, tradotta per Remigio Fiorentino (Venice: Gabriele Giolito, 1549), USTC 762219

Petrarca, Francesco, The tryumphes of Fraunces Petrarcke, translated out of Italian into English by Henrye Parker knyght, Lorde Morley (London: J. Cawood, ca. 1555), USTC 505182

Pliny, The Historie of the World, commonly called, the Natural Historie of C. Plinius Secundus. Translated into English by Philemon Holland, Doctor of Physicke. The First Tome (London: Adam Islip, 1601)

Proclus Diadochus, Procli Diadochi Lycii in primum Euclidis elementorum librum commentariorum ad universam mathematicam disciplinam Principiurn eruditionis tradentium libri IIII a F. B . . cunctis mendis expurgati: schoffis et figuris, que in greco 
codice omnes desiderabantur (sic) aucti: primum iam Romane lingue venustate donate... (Padua: Grazioso Percaccino, 1560), USTC 851416

Rainolds, John, John Rainolds's Lectures on Aristotle's Rhetoric, ed. and trans. Lawrence D. Green (Newark: University of Delaware Press, 1986)

Resines, Luis (ed.), Catecismo del Sacromonte y Doctrina Christiana de Fr. Pedro de Feria: conversión y evangelización de moriscos e indios (Madrid: CSIC, 2002)

Reyes, fray Gaspar de los, Gramática de las lenguas Zapoteca-serrana y Zapoteca del Valle (Oaxaca: Imprenta del Estado, [1704] 1891)

Robert, Raymonde (ed.), Contes: Mademoiselle Lhéritier, Mademoiselle Bernard, Mademoiselle de La Force, Madame Durand, Madame d'Auneuil (Paris: Honoré Champion, 2005)

Sabbadini, Remigio (ed.), Epistolario di Guarino Veronese, (3 vols., Venice: R. Deputazione Veneta di Storia Patria, 1915-1919)

Sahagún, Bernardino de, The Florentine Codex, Book 1: The Gods, trans. and ed. Arthur J. O. Anderson and Charles E. Dibble (Salt Lake City: University of Utah Press, 1950-1982)

Seneca, De' benefizii tradotto in volgar fiorentino da messer Benedetto Varchi (Florence: Lorenzo Torrentino, 1554), USTC 855893

Seneca, Pistole del moralissimo Seneca (Venice: Sebastiano Manilio, and Stefano and Bernardino de' Nalli, 1494), USTC 991131

Sex Linguarum Latinae, Gallica, Hispanicae, Italicae, Anglicae, et Teutonicae dilucidissimus dictionarius (Venice: Francesco Bindoni and Mapheo Pasini, 1549), USTC 346886

Siculus, Diodorus, Diodore de Sicile, Histoire universelle, les trois premiers livres, traduit par Antoine Macault (Paris: Galliot du Pré et Antoine Augereau vend Olivier Mallard, 1535), USTC 24246

St. Basil the Great, 'An Homily or Sermon of St. Basil the Great', trans. Mildred Cecil, in Neil Rhodes, Gordon Kendal, and Louise Wilson (eds.), English Renaissance Translation Theory (London: MHRA, 2013), p. 243

Stein-Kecks, Heidrun (ed.), Die schöne Melusina: Ein Feenroman des 15. Jahrhunderts in der deutschen Übertragung des Thüring von Ringoltingen: Die Bilder im Erstdruck Basel 1473/74 nach dem Exemplar der Universitäts- und Landesbibliothek Darmstatdt (Darmstadt: Wissenschaftliche Buchgesellschaft, 2012)

Terence, L'Andria, et l'Eunucho di Terentio, tradotte in verso sdrucciolo per messer Gio. Giustiniano di Candia (Venice: Giovanni Francesco Torresani, 1544)

Thesaurus polyglottus; vel, Dictionarium Multilingue (Frankfurt: Hieronymo Megisero, 1613), USTC 2042486

Turner, William, A New Herball, (2 vols., Cambridge: Cambridge University Press, 1995)

Turner, William, The seconde part of William Turners herball wherein are conteyned the names of herbes in Greke, Latin, Duche, Frenche, and in the apothecaries Latin, and somtyme in Italiane (Köln: haer. Arnold I Birckmann, 1562), USTC 506046

Tyler, Margaret, Mirror of Princely Deeds and Knighthood, ed. Joyce Boro (London: MHRA, 2014) 
Vetus Testamentum multiplici lingua nunc primo impressum [Complutensian Polyglot] (6 vols., Alcalá de Henares: Arnao Guillén de Brocar, 1514-1517), USTC 344338

Virgil, Bucolica (Florence: Antonio di Bartolommeo Miscomini, 1481/2), USTC 990044 von Bloh, Ute and Wirnst, Silke (eds.), Loher und Maller: Kritische Edition eines spätmittelalterlichen Prosaepos (Berlin: Erich Schmidt, 2013)

von Ringoltingen, Thüring, Melusine (1456). Nach dem Erstdruck Basel: Richel um 1473/74, ed. André Schnyder and Ursula Rautenberg (2 vols., Wiesbaden: Reichert, 2006)

Walton, Brian, The considerator considered: or, a brief view of certain Considerations upon the Biblia Polyglotta, the Prolegomena and Appendix thereof (London: Thomas Roycroft, 1659)

Wilson, Thomas, The Arte of Rhetorique (London: R. Grafton, 1553), USTC 504926

Wolmeinende Erinnerung Von Behauptung deß König und Fürsten Standts, auch Ursachen der Kriege in Europa: An die Könige, und Fürsten, in Lateinischer Sprach unlängst außgangen; Anjetzo aber dem gemeinen Mann zu gutem, auch in die Teutsche ubersetzt / Durch Herman Conraden Freyherrn zu Friedenberg, Rittern, unnd Comitem Palatinum (n. p.: 1620)

Zedler, J. H., Großes Vollständiges Universal-Lexikon aller Wissenschaften und Künste (Halle: Zedler, 1732-1754)

\section{Secondary}

Adamo, Sergia, 'Microhistory in Translation', in Bastin, George L. and Bandia, Paul F. (eds.), Charting the Future of Translation History (Ottawa: The University of Ottawa Press, 2006), pp. 81-100

Agosti, Barbara, 'Vittoria Colonna e il Culto della Maddalena (tra Tiziano e Michelangelo)', in Pina Ragioneri (ed.), Vittoria Colonna e Michelangelo, Casa Buonarroti, Florence, 24 May-12 September, 2005 (Florence: Mandragora, 2005), pp. 71-81

Agoston, Laura Camille, 'Male/Female, Italy/Flanders, Michelangelo/Vittoria Colonna', Renaissance Studies, 58 (2005), pp. 1175-1219

Agoston, Laura Camille, 'Michelangelo as Voice versus Michelangelo as Text', Journal of Medieval and Early Modern Studies, 36 (2006), pp. 135-167

Aguirre, Rodolfo, 'El tercer concilio mexicano frente al sustento del clero parroquial', Estudios de Historia Novohispana 51 (2014), pp. 9-44

Albonico, Simone, Ordine e numero: Studi sul libro di poesia e le raccolte poetiche nel Cinquecento (Alessandria: Edizioni dell'Orso, 2006)

Ames, Christine Caldwell, Righteous Persecution: Inquisition, Dominicans, and Christianity in the Middle Ages (Philadelphia: University of Pennsylvania Press, 2013)

Amossy, Ruth (ed.), Images de soi dans le discours. La construction de l'ethos, (Lausanne: Delachaux and Niestlé, 1999)

Anderson, Benedict, Imagined Communities: Reflections of the Origin and Spread of Nationalism (London: Verso, 1983) 
Andreoni, Annalisa, La via della dottrina: Le lezioni accademiche di Benedetto Varchi (Pisa: ETS, 2012)

Arber, Agnes R., Herbals, their Origins and Evolution: A Chapter in the History of Botany, 1470-1670 (Cambridge: Cambridge University Press, 1938)

Armstrong, Brian G., 'The Changing Face of French Protestantism: The Influence of Pierre Du Moulin', in Robert V. Schnucker (ed.), Calviniana: Ideas and Influence of John Calvin (Kirksville, Missouri: Sixteenth Century Journal Publishers, 1988), pp. 131-149

Armstrong, Brian G., Bibliographia Molincei: An Alphabetical, Chronological and Descriptive Bibliography of the Works of Pierre Du Moulin (1568-1658) (Geneva: Droz, 1997)

Armstrong, Guyda, 'Coding Continental: Information Design in Sixteenth-Century English Vernacular Language Manuals and Translations', Renaissance Studies 29 (2015), pp. 78-102

Armstrong, Guyda, 'Print, Paratext, and a Seventeenth-Century Sammelband: Boccaccio's Ninfale Fiesolano in English Translation', in Barker and Brenda (eds.), pp. 79-99

Backes, Martina, Fremde Historien: Untersuchungen zur Überlieferungs-und Rezeptionsgeschichte französischer Erzählstoffe im deutschen Spätmittelalter (Tübingen: Max Niemeyer, 2004)

Baker, Patrick, Italian Renaissance Humanism in the Mirror (Cambridge: Cambridge University Press, 2015)

Barbato, Marcello, Il Libro VIII del Plinio Napoletano di Giovanni Brancati (Naples: Liguori, 2001)

Barker, Sara K., and Brenda M. Hosington (eds.), Renaissance Cultural Crossroads: Translation, Print and Culture in Britain, 1473-1640 (Leiden: Brill, 2013)

Barnes, Bernadine Ann, Michelangelo in Print (Farnham, Ashgate, 2010)

Barnes, Bernadine Ann, Michelangelo's 'Last Judgment': the Renaissance Response (Berkeley, CA, University of California Press, 1998)

Bassani, Lucia Nadin, Il poligrafo veneto Giuseppe Betussi (Padua: Antenore, 1992)

Bassnet, Susan, 'When is a Translation Not a Translation?', in Susan Bassnet and André Lefevere (eds.), Constructing Cultures: Essays in Literary Translation (Clevedon:

Multilingual Matters, 1998), pp. 25-40

Bastin, Georges L., and Paul F. Bandia, Charting the Future of Translation History (Ottawa: University of Ottawa Press, 2006)

Bataillon, Marcel, Erasmo y España (2 vols., Mexico: Fondo de Cultura Económica, 1950)

Beasley, Faith E., Revising Memory: Women's Fiction and Memoirs in Seventeenth-Century France (New Brunswick: Rutgers University Press, 1990)

Beaulieu, Jean-Philippe, "Moy Traductrice": Le façonnement de la figure auctoriale dans le paratexte des traductions de Marie de Gournay', Renaissance \& Reformation/Renaissance et Reforme, 35 (2012), pp. 119-34

Becker-Cantarino, Barbara, 'Frauen in den Glaubenskämpfen: Öffentliche Briefe, Lieder und Gelegenheitsschriften', in Gisela Brinker-Gabler (ed.), Deutsche Literatur von Frauen (2 vols., Munich: Beck, 1988), I, pp. 149-172 
Becker-Cantarino, Barbara, Der lange Weg zur Mündigkeit: Frau und Literatur (1500-1800) (Stuttgart: Metzler, 1987)

Bell, Susan Groag, 'Medieval Women Book Owners: Arbiters of Lay Piety and Ambassadors of Culture', Signs, 7 (1982), pp. 742-68

Belle, Marie-Alice and Hosington, Brenda M., 'Translation, History, and Print: A Model for the Study of Printed Translations in Early Modern Britain', Translation Studies, 10 (2017), pp. 2-21

Belle, Marie-Alice, “"Mysteries Divulged': Philemon Holland's Paratexts and the Translation of Pliny's Natural History in Early Modern England', Meta 61 (2016), pp. 70-86

Belle, Marie-Alice, '(Auto-) portraits de l'auteur en traducteur: autorité horatienne et ethos du traducteur en Angleterre au XVIIe siècle', Camenae 17 (2015): pp. 1-15

Belle, Marie-Alice, 'At the Interface Between Translation History and Literary History: A Genealogy of the Theme of "Progress" in Seventeenth-century English Translation History and Criticism', The Translator, 20 (2014), pp. 44-63

Belle, Marie-Alice, 'Locating Early Modern Women's Translations: Critical and Historiographical Issues', Renaissance \& Reformation/Renaissance et Reforme, 35 (2012), pp. 5-23

Berbara, Maria, “"Nascentes Morimur”: Francisco de Holanda as Artist, Reader, and Writer', in Heiko Damm, Thimann, The Artist as Reader: on Education and Non-Education in Early Modern Europe (Leiden: Brill, 2013), pp. 387-419

Berschin, Walter, Greek Letters and the Latin Middle Ages: From Jerome to Nicholas of Cusa, trans. Jerold C. Frakes, revised, and expanded edition (Washington DC: The Catholic University of America Press, 1992)

Bibliographie Hispanique (New York: Hispanic Society of America, 1912)

Bietenholz, Peter G., Basle and France in the Sixteenth Century: The Basle Humanists and Printers in Their Contacts with Francophone Culture (Geneva: Droz, 1971)

Bionda, Simone, 'La copia di tipografia del Trattato dei Governi di Bernardo Segni: Breve incursione nel laboratorio del volgarizzatore di Aristotele', Rinascimento 42 (2002), pp. 409442

Bistué, Belén, Collaborative Translation and Multi-Version Texts in Early Modern Europe (Farnham: Ashgate, 2013)

Blaine, Melvin, 'Envy, Eunoia and Ethos in Jonson's Poems on Shakespeare and Drayton', Studies in Philology 106 (2008), pp. 441-455

Blake McHam, Sarah, Pliny and the Artistic Culture of the Italian Renaissance (New Haven: Yale University Press, 2013)

Bloh, Ute von, Ausgerenkte Ordnung: Vier Prosaepen aus dem Umkreis der Gräfin Elisabeth von Nassau-Saarbrücken: 'Herzog Herpin', 'Lother und Maller', 'Hugo Scheppel', 'Königin Sibille' (Tübingen: Max Niemeyer, 2002)

Bober, Phyllis Pray and Rubinstein, Ruth. Renaissance Artists and Antique Sculpture (London: Harvey Miller Publishers, 1986)

Bod, Rens, A New History of the Humanities: The Search for Principles and Patterns from Antiquity to the Present (Oxford: Oxford University Press, 2013) 
Bongi, Salvatore, Annali di Gabriel Giolito de' Ferrari da Trino di Monferrato stampatore in Venezia (2 vols., Rome: Ministero della Pubblica Istruzione, 1890-1897)

Boro, Joyce, 'Multilingualism, Romance, and Language Pedagogy; or, Why Were So Many Sentimental Romances Printed as Polyglot Texts?', in Fred Schurink (ed.), Tudor Translation (New York: Palgrave Macmillan, 2011), pp. 18-38

Bottigheimer, Ruth B., and Raynard, Sophie, 'Fairy Tales and Fairyland Fictions in France', in Fairy Tales Framed: Early Forewords, Afterwords, and Critical Words (Albany: State University of New York Press, 2012), pp. 101-111

Bottigheimer, Ruth B., and Raynard, Sophie, 'Marie-Jeanne Lhéritier de Villandon, "Diverse Works" (1696)', in Fairy Tales Framed: Early Forewords, Afterwords, and Critical Words (Albany: State University of New York Press, 2012), pp. 127-154

Boutcher, Warren, 'Intertraffic: Transnational Literatures and Languages in Late Renaissance England and Europe', in Matthew McLean and Sara K. Barker (eds.), International Exchange in the Early Modern Book World (Leiden: Brill, 2016), pp. 343-374

Boutcher, Warren, 'The Renaissance', in Peter France (ed.), The Oxford Guide to English Literature in Translation (Oxford: Oxford University Press, 2000), pp. 45-55

Brace, Patricia, 'Speaking Pictures: Margaret Roper and the Representation of Lady Rhetoric', Moreana 50 (2013): pp. 93-130

Braden, Gordon etc. (eds.), The Oxford History of Literary Translation in English (4 vols., Oxford: Oxford University Press, 2010)

Brancato Dario, 'Benedetto Varchi traduttore di Boezio', in ed. Vanni Bramanti (ed.), Benedetto Varchi (1503-2003): Atti del convegno (Firenze, 16-17 dicembre 2003) (Rome: Edizioni di Storia e Letteratura, 2007), pp. 95-155

Brancato, Dario, 'La lettera dedicatoria della Consolazione della filosofia di Benedetto Varchi e le teorie linguistiche tardocinquecentesche', Studi rinascimentali, 1 (2003): pp. 8393

Brancato, Dario, 'Readers and Interpreters of the Consolation in Italy, 1300-1550', in Noel H. Kaylor and Philip E. Phillips (eds.), A Companion to Boethius in the Middle Ages (Leiden: Brill, 2012), pp. 357-411

Breva-Claramonte, Manuel, La didáctica de las lenguas en el Renacimiento: Juan Luis Vives y Pedro Simón Abril (Bilbao: Universidad de Deusto, 1994)

Broadwell, George A., 'The historical development of progressive aspect in Central Zapotec', International Journal of American Linguistics 81 (2015), pp. 151-185

Brothers, Cammy, 'Reconstruction as Design: Giuliano da Sangallo and the "palazo di mecenate" on the Quirinal Hill', Annali di architettura, 14 (2002), pp. 55-72

Brown, Cynthia J., “Text, Image, and Authorial Self-consciousness in Late Medieval Paris", in Printing in the Written Word: The Social History of Books, circa 1450-1520, ed. Sandra Hindman (Ithaca NY: Cornell University Press, 1991)

Brown, Hilary, 'Rethinking Agency and Creativity: Translation, Collaboration, and Gender in Early Modern Germany', Translation Studies, 10 (2017) (accessed on 23 April 2017)

Brummer, Hans H., The Statue Court in the Vatican Belvedere (Stockholm: Alquist and Wiksell, 1970) 
Buden, Boris etc., 'Cultural Translation: An Introduction to the Problem, and Responses', Translation Studies, 2 (2009), pp. 196-219

Bumke, Joachim, Die romanisch-deutschen Literaturbeziehungen im Mittelalter. Ein Überblick (Heidelberg: Winter, 1967)

Burchert, Bernhard, Die Anfänge des Prosaromans in Deutschland: Die Prosaerzählungen Elisabeths von Nassau-Saarbrücken (Frankfurt, Bern, and New York: Peter Lang, 1987)

Burke, Jill, Changing Patrons: Social Identity and the Visual Arts in Renaissance Florence (University Park: Pennsylvania State University Press, 2004)

Burke, Peter, 'The Translator As Go-Between', in Andreas Höfele and Werner von Koppenfels, Renaissance Go-Betweens: Cultural Exchange in Early Modern Europe (Berlin: De Gruyter, 2005), pp. 17-31

Burke, Peter and Po-chsia Hsia, R. (eds.), Cultural Translation in Early Modern Europe (Cambridge and New York: Cambridge University Press, 2007)

Burkhart, Louise, The Slippery Earth: Nahua-Christian Moral Dialogue in Sixteenth-Century Mexico (Tucson: University of Arizona Press, 1989)

Bury, John B., Two Notes on Francisco de Holanda (London: The Warburg Institute, University of London, 1981)

Calvillo, Elena, 'Inventive Translation, Portraiture and Spanish Habsburg Taste', in Piers Baker-Bates and Miles Pattenden (eds.), The Spanish Presence in Sixteenth-Century Italy: Images of Iberia (Farnham, Ashgate, 2015), pp. 175-97

Calvillo, Elena, 'Reading Pliny in Francisco de Holanda's "Roman Dialogues"', in Melinda Schlitt (ed.), Gifts in Return: Essays in Honor of Charles Dempsey (Toronto: Centre for Reformation and Renaissance Studies, 2012), pp. 263-296

Calvillo, Elena, 'Review of Francisco de Hollanda, On Antique Painting, trans. and ed. Alice Sedgwick Wohl (University Park: Pennsylvania State Press, 2013), CAA Reviews, http://www.caareviews.org/reviews/2443\#.V D8ghGoVAQ (accessed 2 May 2017)

Camille, Michael, 'Play, Piety and Perversity in Medieval Marginal Manuscript Illumination', in Katrin Kroll and Hugo Steher (eds.), Mein ganzer Körper ist Gesicht. Grotesque Darstellungen in der europäischen Kunst und Literatur des Mittelalters, (Freiburg: Rombach Verlag, 1994), pp. 171-192

Camille, Michael, Image on the Edge: The Margins of Medieval Art (London: Reaktion Books, 1992)

Camille, Michael, The Gothic Idol: Ideology and Image-Making in Medieval Art (Cambridge: Cambridge University Press, 1989

Campbell, Emma and Mills, Robert (eds.), Rethinking Medieval Translation: Ethics, Politics, Theory (Cambridge: D. S. Brewer, 2012)

Campbell, Stephen J. and Milner, Stephen J. (eds.), Artistic Exchange and Cultural Translation in the Italian Renaissance City (Cambridge, Cambridge University Press, 2004)

Campbell, Stephen J., 'Mantegna's Triumph: the Cultural Politics of Imitation 'all'antica' at the Court of Mantua, 1490-1530', in Stephen J. Campbell (ed.), Artists at Court: Imagemaking and Identity, 1300-1550 (Chicago: University of Chicago Press, 2004), pp. 91-219

Carabell, Paula, 'Breaking the Frame: Transgression and Transformation in Giulio Romano's Sala dei Giganti', Artibus et Historiae, 18 (1997), pp. 88-100 
Carrai, Stefano, 'Minturno traduttore di Plutarco in un manoscritto della Nazionale di Madrid', Italia medioevale e umanistica, 37 (1994), pp. 233-239

Carrdus, Anna, 'Women's Writing in the Context of their Lives, 1520-1720', in Max Reinhart (ed.), Early Modern German Literature 1350-1700 (Rochester, NY: Camden House, 2007), pp. 869-903

Cawsey, Kathleen and Harris, Jason (eds.), Transmission and Transformation in the Middle Ages: Texts and Contexts (Dublin: Four Courts, 2007)

Celenza, Christopher, 'End Game: Humanist Latin in the Fifteenth Century', in Y. Maes, J. Papy, and W. Verbaal (eds.), Latinitas Perennis II: Appropriation and Latin Literature (Leiden: Brill, 2009), pp. 201-242

Cervantes, Fernando, The Devil in the New World (New Haven: Yale University Press, 1994)

Chavy, Paul Traducteurs d'autrefois: moyen âge et renaissance; dictionnaire des traducteurs et de la littérature traduite en ancien et moyen français (842-1600), (2 vols., Paris:

Champion-Slatkine, 1988)

Choloman, Tamar and Pinkus, Asaaf (eds.), The Sides of the North: An Anthology in Honor of Professor Yona Pinson (Cambridge: Cambridge Scholars Publishing, 2015)

Christensen, Mark Z., Nahua and Maya Catholicisms: Texts and Religion in Colonial Central Mexico and Yucatan (Stanford, CA: Stanford University Press, 2013)

Clarke, Danielle, 'Translation', in Laura Lunger Knoppers (ed.), The Cambridge Companion to Early Modern Women's Writing (Cambridge: Cambridge University Press, 2009), pp. $167-180$

Clarke, Danielle, The Politics of Early Modern Women's Writing (Harlow: Longman, 2001)

Classen, Albrecht (ed.), Multilingualism in the Middle Ages and Early Modern Age:

Communication and Miscommunication in the Premodern World (Berlin and Boston: Walter de Gruyter, 2016)

Classen, Albrecht, 'Frauen in der deutschen Reformation: Neufunde von Texten und Autorinnen sowie deren Neubewertung', in Paul Gerhard Schmidt (ed.), Die Frau in der Renaissance (Wiesbaden: Harrassowitz, 1994), pp. 179-201

Classen, Albrecht, 'Noch einmal zu Wolframs 'spekulativer' Kyôt -Quelle im Licht jüdischer Kultur und Philosophie des zwölften Jahrhunderts', Studi medievali, 46 (2005), pp. 281-308

Classen, Albrecht, 'Schrecken und Grauen, Mord und Totschlag: Das Entsetzen literarisch eingefangen. Spiegelung des Schmerzes und brutaler Misshandlungen in Elisabeths von Nassau-Saarbrücken Loher und Maller (1437)', Neuphilologische Mitteilungen, 116 (2015): pp. 133-147

Classen, Albrecht, 'Women in $15^{\text {th }}$-Century Literature: Protagonists (Melusine), Poets (Elisabeth von Nassau-Saarbrücken), and Patrons (Mechthild von Österreich)', in James Hardin and Jörg Jungmayr (eds.), 'Der Buchstab tödt - der Geist macht lebendig'. Festschrift zum 60. Geburtstag von Hans-Gert Roloff (2 vols., Bern: Peter Lang, 1992), I, pp. 431-458

Chesterman, Andrew, 'Hypotheses about Translation Universals', in G. Hansen etc. (eds.), Claims, Changes, and Challenges in Translation Studies (Amsterdam: Benjamins, 2004), pp. $1-13$

Classen, Albrecht, An English Translation of Rudolf von Ems's 'Der guote Gêrhart' (Newcastle Upon Tyne: Cambridge Scholars Press, 2016) 
Classen, Albrecht, Deutsche Schwankliteratur des 16. Jahrhunderts: Studien zu Martin Montanus, Hans Wilhelm Kirchhof und Michael Lindener (Trier: Wissenschaftlicher Verlag Trier, 2009)

Classen, Albrecht, Late-Medieval German Women's Poetry (Cambridge: Brewer, 2004)

Classen, Albrecht, The German Volksbuch. A Critical History of a Late-Medieval Genre. (Lewiston NY: Edwin Mellen Press, 1995)

Cohen, Matt, The Networked Wilderness: Communicating in Early New England (Minneapolis: University of Minnesota Press, 2010)

Cohen, Simona, Animals as Disguised Symbols in Renaissance Art (Leiden: Brill, 2008)

Cointre, Annie, 'Prose Narrative', in Yves Chevrel, Annie Cointre, and Yen-Maï Tran-Gervat (eds.), Histoire des traductions en langue française, XVIIe et XVIIIe siècles: 1610-1815 (Lagrasse: Verdier, 2014), pp. 1121-1209

Coldiron, Anne E. B., 'Form(e)s of Transnationhood: The Case of John Wolfe's Trilingual Courtier', Renaissance Studies 29 (2015), pp. 103-124

Coldiron, Anne E. B., 'Response to "Translation and the Materialities of Communication"', Translation Studies, 9 (2016), pp. 96-102

Coldiron, Anne E. B., 'The Translator's Visibility in Early Printed Portrait-Images', in M. Belle and B. Hosington (eds.), Thresholds of Translation: Paratexts, Print, and Cultural Exchange in Early Modern Britain (London: Palgrave, forthcoming 2017)

Coldiron, Anne E. B., 'Visibility Now: Historicizing Foreign Presences in Translation, Translation Studies, 5 (2012), pp. 189-200

Coldiron, Anne E. B., Printers Without Borders: Translation and Textuality in the Renaissance (Cambridge: Cambridge University Press, 2014)

Coldiron, Anne E. B., 'Commonplaces and Metaphors', in The Oxford History of Literary Translation into English, Gordon Braden and Robert Cummings (eds.) (5 vols., Oxford: Oxford University Press, 2010), II, pp. 109-120

Coldiron, Anne E. B., 'The Translator's Visibility in Early Printed Portrait-Images and the Ambiguous Example of Margaret More Roper', in Marie-Alice Belle and Brenda Hosington (eds.), Thresholds of Translation: Paratexts, Print, and Cultural Exchange in Early Modern Britain (Basingstoke: Palgrave MacMillan, forthcoming, 2017)

Conermann, Klaus, 'Die fürstliche Offizin zu Köthen: Druckerei, Verlagswesen und Buchhandel im Dienste des Ratichianismus und der Fruchtbringenden Gesellschaft (16181644/50)', Wolfenbütteler Barock-Nachrichten, 24 (1994), pp. 121-178

Conermann, Klaus, 'Die Tugendliche Gesellschaft und ihr Verhältnis zur Fruchtbringenden Gesellschaft: Sittenzucht, Gesellschaftsidee und Akademiegedanke zwischen Renaissance und Aufklärung', Daphnis, 17 (1988), pp. 513-626

Conermann, Klaus, 'Editionsdesiderate: Die Werke der Fürsten Ludwig und Christian II. von Anhalt im Kontext der Akademiearbeiten der Fruchtbringenden Gesellschaft', in Hans-Gert Roloff (ed.), Editionsdesiderate der Frühen Neuzeit: Beiträge zur Tagung der Kommission für die Edition von Texten der Frühen Neuzeit (2 vols., Amsterdam: Rodopi, 1997), pp. 390490

Copeland, Rita, Rhetoric, Hermeneutics and Translation in the Middle Ages: Academic Tradition and Vernacular Texts (Cambridge: Cambridge University Press, 1991) 
Coppini, Donatella and Regoliosi, Mariangela (eds.), Gli umanisti e Agostino. Codici in mostra (Florence: Edizioni Polistampa, 2001)

Corcuera de Mancera, Sonia, 'Cuestión de palabras: el indio en el III Concilio Provincial Mexicano', in Francisco Cervantes and María del Pilar Martínez (eds.), Los concilios provinciales en Nueva España (Mexico City: UNAM, 2005)

Cordingley, Anthony and Frigau Manning, Céline (eds.), Collaborative Translation. From the Renaissance to the Digital Age (London, Oxford, and New York: Bloomsbury Publishing, 2017)

Cox, Virginia, The Renaissance Dialogue (Cambridge, Cambridge University Press, 1992)

Crawford, Julie, 'Reconsidering Early Modern Women's Reading, or, How Margaret Hoby Read Her de Mornay', Huntington Library Quarterly, 73 (2010), pp. 193-223

Crawford, Julie, Mediatrix: Women, Politics and Literary Production in Early Modern England (Oxford: Oxford University Press, 2014)

Curtright, Travis, 'Sidney's Defense of Poetry: Ethos and the Ideas', Ben Jonson Journal 10 (2003), pp. 101-115

D’Elia, Una Romana, 'Drawing Christ's Blood: Vittoria Colonna, Michelangelo, and the Aesthetics of Reform', Renaissance Quarterly, 59 (2006), pp. 90-129

Dall'Aglio, Stefano, The Duke's Assassin: Exile and Death of Lorenzino de' Medici, trans. Donald Weinstein (New Haven: Yale University Press, 2015)

Dane, Joseph A., "“Wanting the First Blank": Frontispiece to the Huntington Copy of Caxton's Recuyell of the Historyes of Troye', Huntington Library Quarterly, 67 (2004), pp. $315-325$

Darlow, Thomas H. and Moule, Horace F., Historical Catalogue of the Printed Editions of Holy Scripture in the Library of the British and Foreign Bible Society (2 vols., New York: Kraus Reprint, 1963)

Deane-Cox, Sharon, Retranslation: Translation, Literature, and Reinterpretation (London, Oxford, and New York: Bloomsbury Publishing, 2014)

de Beer, Susanna, The Poetics of Patronage: Poetry as Self-Advancement in Giannantonio Campano (Turnout: Brepols, 2013)

De Laurentiis Accornero, Elena, 'Giovanni Battista Castello "Il Genovese", Giulio Clovio e lo 'scriptorium' dell'Escorial”, in Piero Boccardo, José Luis Colomer, Clario Di Fabio (eds.), Genova e la Spagna: opere, artisti, committenti, collezionisti (Milan: Silvana Editore, 2002), pp. $156-165$

De Leemans, Pieter and Goyens, Michèle (eds.), The Medieval Translator: Translator and Authority (Turnhout: Brepols, 2016)

Dearnley, Elizabeth, Translators and Their Prologues in Medieval England (Woodbridge UK: D. S. Brewer, 2016)

DeJean, Joan E., Ancients against Moderns: Culture Wars and the Making of a Fin de Siècle (Chicago: University of Chicago Press, 1997)

DeJean, Joan E., Fictions of Sappho, 1546-1937 (Chicago: University of Chicago Press, 1989) 
DeJean, Joan E., Tender Geographies: Women and the Origins of the Novel in France (New York: Columbia University Press, 1991)

del Mar Rivas Carmona, María and del Carmen Balbuena Torezano, María (eds.), Cultural Aspects of Translation (Tübingen: Narr, 2013)

Demers, Patricia, Women's Writing in English: Early Modern England (Toronto: University of Toronto Press, 2005)

Demetriou, Tania, and Tomlinson, Rowan Cerys, 'Introduction: “Abroad in Mens Hands": The Culture of Translation in Early Modern England and France', in The Culture of Translation in Early Modern England and France, 1500-1660 (Basingstoke: Palgrave Macmillan, 2015), pp. 1-21

Demetriou, Tania, and Tomlinson, Rowan Cerys (eds.), The Culture of Translation in Early Modern England and France, 1500-1660 (Basingstoke and New York: Palgrave Macmillan, 2015)

Dempsey, Charles. 'Mythic Inventions in Counter-Reformation Painting', in P.A Ramsay (ed.), Rome in the Renaissance: the City and the Myth (Binghamton, NY:

Medieval and Renaissance Texts and Studies, Center for Medieval and Early Renaissance Studies, 1982), pp. 55-75

Denton, John, 'Translators and their Tools in the European Renaissance', in Harald Kittel etc. (eds.), Übersetzung - Translation - Traduction: Ein internationales Handbuch zur Übersetzungsforschung (3 vols., Berlin: de Gruyter, 2004-2011), II, pp. 1415-1419

Deswarte-Rosa, Sylvie, 'A viagem a Itália de Francisco de Holanda (1538-1540)', in Os Descobrimentos portugueses e a Europa do Renascimento (Lisbon: Presidència do Conselho de Ministros, 1983), pp. 61-65

Deswarte-Rosa, Sylvie, 'Francisco de Holanda et le Cortile de Belvedere', in Matthias Winner, Bernard Andreae, and Carlo Pietrangeli, Il Cortile delle Statue: der Statuenhof des Belvedere im Vatikan. Akten des internationalen Kongresses zu Ehren von Richard Krautheimer, Rom, 21-23 Oktober, 1992 (Mainz: Verlag Philipp von Zabern, 1998), pp. 389-410

Deswarte-Rosa, Sylvie, 'Le Rameau d'Or et de Science. "F. Ollandius Apolini Dicavit"', Pegasus. Berliner Beiträge zum Nachleben der Antike 7 (2005), pp. 9-47

Deswarte-Rosa, Sylvie, 'Rome déchue. Décomposition d'une image de Francisco de Holanda', Monuments et Mémoires Eugène Piot, 71 (1990), pp. 97-181

Deswarte-Rosa, Sylvie, 'Vittoria Colonna und Michelangelo in San Silvestro al Quirinal nach den Gesprächen des Francisco de Holanda', in Sylvia Ferino-Pagden (ed.), Vittoria Colonna: Dichterin und Muse Michelangelos (Vienna: Skira, 1997), pp. 349-373

Deswarte-Rosa, Sylvie, Ideias e imagens em Portugal na época dos Escobrimentos: Francisco de Holanda e a Teoria da Arte (Lisbon: Difel, 1992)

di Majo, Ippolita. 'Vittoria Colonna, il Castello di Ischia e la cultura di Ischia e la cultura delle corti', in Pina Ragionieri (ed.), Vittoria Colonna e Michelangelo, Casa Buonarroti, Florence, 24 May-12 September, 2005 (Florence: Mandragora, 2005), pp. 19-32

Dionisotti, Carlo, 'Tradizione classica e volgarizzamenti', in Geografia e storia della letteratura italiana (Turin: Einaudi, 1967), pp. 103-144

Duff, E. Gordon, The Printers, Stationers, and Bookbinders of Westminster and London from 1476 to 1535 (Cambridge: Cambridge University Press, 1906) 
Duffy, Eamon, Marking the Hours: English People and their Prayers, 1240-1570 (New Haven, CO: Yale University Press, 2006)

Dunn, Kevin, Pretexts of Authority: The Rhetoric of Authorship in the Renaissance Preface (Stanford: Stanford University Press, 1994)

Dünnhaupt, Gerhard, 'Die Fürstliche Druckerei zu Köthen: Ein Beitrag zum 400. Geburtstage des Fürsten Ludwig von Anhalt-Köthen (1579-1650)', Archiv für Geschichte des Buchwesens, 20 (1979), pp. 896-950

Dünnhaupt, Gerhard, 'Die Übersetzungen Fürst Ludwigs von Anhalt-Köthen: Ein Beitrag zum 400. Geburtstag des Gründers der Fruchtbringenden Gesellschaft', Daphnis, 7 (1978), pp. 513-529

Elsky, Martin, Authorizing Words: Speech, Writing and Print in the English Renaissance (Ithaca: Cornell University Press, 1989)

Enenkel, Karl A. E. and Smith, Paul J. (eds.), Zoology in Early Modern Culture:

Intersections of Science, Theology, Philology, and Political and Religious education, (Leiden and Boston: Brill, 2014)

Ezell, Margaret, Social Authorship and the Advent of Print (Baltimore MD: Johns Hopkins University Press, 1999)

Farriss, Nancy, Libana. El discurso ceremonial mesoamericano y el sermón cristiano (Mexico City: Artes de México, Biblioteca Fray Juan de Córdova, Fundación Alfredo Harp Helú, 2014)

Federici Federico M., and Tessicini, Dario (eds.), Translators, Interpreters and Cultural Negotiators: Mediating and Communicating Power from the Middle Ages to the Modern Era (New York: Palgrave Macmillan, 2014)

Felicidade Alves, José da (ed.), Álbum dos Desenhos das Antigualhas (Lisbon: Livros Horizonte, 1989)

Ferino-Pagden, Sylvia (ed.), Vittoria Colonna: Dichterin und Muse Michelangelos (Vienna: Kunsthistorischen Museums and Skira, 1997)

Fernández, José María, and Wilson Lee, Edward, 'Introduction', in José María Fernández and Edward Wilson Lee (eds.), Translation and the Book Trade in Early Modern Europe (Cambridge: Cambridge University Press, 2015), pp. 1-21

Fiamminghi a Roma, 1508-1608. Artistes des Pays-Bas et de la principalité de Liège à Rome (Ghent: Snoeck-Ducaju and Zoon, 1995)

Filimonova, Elena (ed.), Clusivity: Typology and case studies of the inclusive-exclusive distinction (Amsterdam and Philadelphia: John Benjamins, 2005)

Foz, C., 'Translation, History, and the Translation Scholar', in G. Bastin and P. Bandia (eds.), Charting the Future of Translation History (Ottawa: University of Ottawa Press, 2006), pp. 131-144

Fragnito, Gigliola, 'Vittoria Colonna e il dissenso religioso', in Pina Ragionieri (ed.), Vittoria Colonna e Michelangelo, Casa Buonarroti, Florence, 24 May-12 September, 2005 (Florence: Mandragora, 2005), pp. 97-105

Fragnito, Gigliola, La Bibbia al rogo: La censura ecclesiastica e $i$ volgarizzamenti della Scrittura (1471-1605) (Bologna: Il Mulino, 1997) 
Fudge, Erica, Perceiving Animals: Humans and Beasts in Early Modern English Culture (Urbana: University of Illinois Press, 2002)

Fumagalli, Edoardo, Matteo Maria Boiardo, volgarizzatore dell' 'Asino d'oro': Contributo allo studio della fortuna di Apuleio nell'umanesimo (Padua: Antenore, 1988)

Fumaroli, Marc, 'Les abeilles et les araignées', in Anne-Marie Lecoq (ed.), La querelle des Anciens et des Modernes: XVIIe-XVIIIe siècles, edited by (Paris: Gallimard, 2001), pp. 7-218

Füssel, Stephan, 'Early Modern German Printing', in Max Reinhart (ed.), Early Modern German Literature 1350-1700 (Rochester, NY: Camden House, 2007), pp. 217-246

García Pimentel, Luis (ed.), Relación de los obispados de Tlaxcala, Michoacán, Oaxaca, y otros lugares en el siglo XVI (Mexico City: Luis García Pimentel, 1904)

Garzelli, Annarosa (ed.), Miniatura fiorentina del primo rinascimento (1440-1525). Un primo censimento (2 vols., Florence: La Nuova Italia, 1985)

Genette, Gérard, Paratexts: Thresholds of Interpretation (Cambridge and New York: Cambridge University Press, 1997)

Gennaioli, Riccardo (ed.), Pregio e bellezza. Cammei e intagli dei Medici (Livorno: Sillabe, 2010)

Gentile, Sebastiano (ed.), Umanesimo e Padri della Chiesa. Manoscritti e incunaboli di testi patristici da Francesco Petrarca al primo Cinquecento (Milan: Rose, 1997)

Gillespie, Stuart, 'Vernacular Translations of Classical and Neo-Latin Writings in the European Renaissance: the Germanic Languages', in Harald Kittel etc. (eds.), Übersetzung Translation - Traduction: Ein internationales Handbuch zur Übersetzungsforschung (3 vols., Berlin: de Gruyter, 2004-2011), II, pp. 1441-1447

Girault, Pierre-Gilles, François Ier, images d'un roi. De l'histoire à la légende (Paris: Somogy éditions, 2006)

Goodrich, Jaime, 'Early Modern Englishwomen as Translators of Political Literature', PhD Thesis, Boston College, 2008

Goodrich, Jaime, 'Mary Tudor, Lord Morley, and St. Thomas Aquinas: The Politics of Pious Translation at the Henrician Court', $A N Q 24$ (2011), pp. 11-20

Goodrich, Jaime, Faithful Translators: Authorship, Gender, and Religion in Early Modern England (Evanston IL: Northwestern University Press, 2014)

Gotzkowsky, Bodo, 'Volksbücher': Prosaromane, Renaissancenovellen, Versdichtungen und Schwankbücher. Bibliographie der deutschen Drucke (2 vols., Baden-Baden: Valentin Koerner, 1991)

Gouwens, Kenneth, 'Human Exceptionalism', in John Jeffries Martin (ed.), The Renaissance World (New York: Routledge, 2007), pp. 415-434

Green, D. H., Medieval Listening and Reading: The Primary Reception of German Literature 800-1300 (Cambridge UK: Cambride University Press, 1994)

Green, Jonathan, 'Translating time: chronicle, prognostication, prophecy', Renaissance Studies, 29 (2015), pp. 162-177

Greene, Thomas M., The Light in Troy: Imitation and Discovery in Renaissance Poetry (New Haven: Yale University Press, 1982) 
Guthmüller, Bodo, 'Letteratura nazionale e traduzione dei classici nel Cinquecento', Lettere italiane, 45 (1993), pp. 501-518

Guthmüller, Bodo, Ovidio Metamorphoseos Vulgare: Forme e funzioni della trasposizione in volgare della poesia classica nel Rinascimento italiano (Fiesole: Cadmo, 2008),

Hahn, Reinhard (ed.), Eleonore von Österreich: Pontus und Sidonia (Berlin: Erich Schmidt, 1997)

Hahn, Reinhard, 'Von frantzosischer zungen in teütsch'. Das literarische Leben am Innsbrucker Hof des späteren 15. Jahrhunderts und der Prosaroman 'Pontus und Sidonia (A)' (Frankfurt and Bern: Peter Lang, 1990)

Halbertal, Moshe, and Margalit, Avishai, Idolatry (Cambridge, MA: Harvard University Press, 1992)

Hall McCash, June (ed.), The Patronage of Medieval Women (Athens GA: University of Georgia Press, 1996)

Hamilton, Albert Charles (ed.), The Spenser Encyclopedia (Toronto: University of Toronto Press, 1990)

Hannay, Margaret P. 'Introduction', in Margaret Patterson Hannay (ed.), Silent But for the Word: Tudor Women as Patrons, Translators and Writers of Religious Works (Kent, OH: The Kent State University Press, 1985), pp. 1-14

Hartfelder, Karl, Deutsche Uebersetzungen klassischer Schriftsteller aus dem Heidelberger Humanistenkreis (Heidelberg: Mohr, 1884)

Hartt, Frederick, Giulio Romano (2 vols., New Haven: Yale University Press, 1958)

Haskell, Francis, Patrons and Painters: A Study in the Relations between Italian Art and Society in the Age of the Baroque (London: Chatto \& Windus, 1963)

Haubrichs, Wolfgang and Oster, Patricia (eds.), Zwischen Herrschaft und Kunst: Fürstliche und adlige Frauen im Zeitalter Elisabeths von Nassau-Saarbrücken (14.-16. Jh.)

(Saarbrücken: SDV Saarländische Druckerei und Verlag, 2013)

Hayes, Julie Candler, Translation, Subjectivity, and Culture in France and England, 16001800 (Stanford: Stanford University Press, 2009)

Hedeman, Anne D., Translating the Past: Laurent de Premierfait and Boccaccio's De Casibus (Los Angeles: Getty Publications, 2008)

Henderson, Judith Rice, 'Humanist Letter-Writing: Private Conversation or Public Forum?', in Todt Van Hoot, Jan Papy, and Gilbert Tournoy (eds.), Self-presentation and Social Identification: The Rhetoric and Pragmatics of Letter Writing in Early Modern Times (Leuven: Leuven University Press, 2002), pp. 17-38

Hess, Ursula, 'Lateinischer Dialog und gelehrte Partnerschaft: Frauen als humanistische Leitbilder in Deutschland (1500-1550)', in Gisela Brinker-Gabler (ed.), Deutsche Literatur von Frauen, (2 vols., Munich: Beck, 1988), I, pp. 113-148

Higman, Francis M., 'Ideas for Export: Translations in the Early Reformation', in Jean R. Brink and William F. Gentrup (eds.), Renaissance Culture in Context: Theory and Practice (Aldershot: Scolar, 1993), pp. 100-113

Hirst, Michael, Tre saggi su Michelangelo (Florence, Mandragora, 2004) 
Hobson, Anthony, Renaissance Book Collecting: Jean Grolier and Diego Hurtado de Mendoza, their Books and Bindings (Cambridge: Cambridge University Press, 1999)

Hollengreen, Laura H. and Holden, Laura (eds.), Translatio or the Transmission of Culture in the Middle Ages and Renaissance: Modes and Messages (Turnhout: Brepols, 2008)

Hollingsworth, Mary, Patronage in Renaissance Italy: From 1400 to the Early Sixteenth Century (London: John Murray, 1994)

Hope, Charles, 'Francisco de Hollanda and Art Theory, Humanism and Neoplatonism in Italy' in Francisco de Hollanda, On Antique Painting, ed. and trans. Alice Sedgwick Wohl (University Park, PA.: Pennsylvania State University Press, 2013), pp. 45-64

Hosington, Brenda M. (ed.), Renaissance Cultural Crossroads Catalogue of Printed Translations, 1473-1640 at https://www.hrionline.ac.uk/rcc/

Hosington, Brenda M. 'Women Translators and the Early Printed Book', in Vincent Gillespie and Susan Powell (eds.), A Companion to the Early Printed Book in Britain 1476-1558 (Cambridge: Brewer, 2014), pp. 248-271

Hosington, Brenda M., 'English Printers and the Nature of the Translated Title-page', in Thresholds of Translation (forthcoming, 2017)

Hosington, Brenda M., "The "Renaissance Cultural Crossroads" Catalogue: A Witness to the Importance of Translation in Early Modern Britain', in Malcolm Walsby and Graeme Kemp (eds.), The Book Triumphant: Print in Transition in the Sixteenth and Seventeenth Centuries (Leiden: Brill, 2011), pp. 253-269

Hosington, Brenda M., 'The Role of Translations and Translators in the Production of English Incunabula', in Sara Barker and Brenda Hosington (eds.), Renaissance Cultural Crossroads: Translation, Print, and Culture in Britain, 1473-1640 (Leiden: Brill, 2013), pp. $3-20$

Hosington, Brenda M., 'Translation and Print Culture in Early Modern Europe', Renaissance Studies 29 (2015), pp. 5-18

Hosington, Brenda M., 'Translation as a Currency of Cultural Exchange in Early Modern England', in Helen Hackett (ed.), Early Modern Exchanges: Dialogues Between Nations and Cultures, 1550-1750 (New York: Routledge, 2016), pp. 27-54

Hosington, Brenda M., and Hannah Fournier, 'Translation and Women Translators', in Diana Robin etc. (eds.), Encyclopedia of Women in the Renaissance: Italy, France and England (Santa Barbara: ABC-Clio, 2007), pp. 369-375

Hunt, Elizabeth Moore, 'The Naked Jongleur in the Margins: Manuscript Contexts for Social Meanings', in Sherry C. M. Lindquist (ed.), The Meanings of Nudity in Medieval Art (Farnham: Ashgate, 2012), pp. 85-103

Ianziti, Gary, Writing History in Renaissance Italy: Leonardo Bruni and the Uses of the Past (Cambridge: Harvard University Press, 2012)

Inghilleri, Moira, 'Mediating Zones of Uncertainty. Interpreter Agency, the Interpreting Habitus and Political Asylum Adjudication,' The Translator, 11 (2014), pp. 69-85

Janson, Horst W., Apes and Apes Lore in the Middle Ages and the Renaissance (London: Warburg Institute, University of London, 1952)

Jardine, Lisa and Grafton, Anthony, "'Studied for Action": How Gabriel Harvey Read his Livy', Past and Present, 129 (1990), pp. 30-78 
Jasmin, Nadine, 'Sophistication and Modernization of the Fairy Tale: 1690-1709', in Sophie Raynard (ed.), The Teller's Tale: Lives of the Classic Fairy Tale Writers (New York: SUNY Press, 2012), pp. 41-46

Johns, Adrian, The Nature of the Book: Print and Knowledge in the Making (Chicago: Chicago University Press, 2008)

Jones, William Jervis, German Lexicography in the European Context: A Descriptive Bibliography of Printed Dictionaries and Word Lists Containing German Language (16001700) (Berlin: Walter de Gruyter, 2000)

Joseph, Miriam Sister, Shakespeare's Use of the Arts of Language (Philadelphia: Paul Dry, 2005 [1947])

Keith, Thomas, Man and the Natural World: Changing Attitudes in England, 1500-1800 (Harmondsworth: Penguin, 1984)

Kekewich, Margaret, 'Edward IV, William Caxton, and Literary Patronage in Yorkist England', The Modern Language Review, 66 (1971), pp. 481-487

Kelly, Douglas, The Art of Medieval French Romance (Madison: University of Wisconsin Press, 1992)

Kelly, Joan, 'Did Women Have a Renaissance?' In Renate Bridenthal and Claudia Koonz (eds.), Becoming Visible: Women in European History, pp. 137-164 (Boston: Houghton Mifflin, 1977)

Kent, Dale V., Cosimo de' Medici and the Florentine Renaissance: The Patron's Oeuvre (New Haven: Yale University Press, 2000)

Kent, Francis W., Simons, Patricia and Eade, John C. (eds.), Patronage, Art, and Society in Renaissance Italy (Canberra and New York: Oxford University Press, 1987

Kilroy, Gerard, 'Advertising the Reader: Sir John Harington's “directions in the Margent" [with Illustrations]', English Literary Renaissance, 41 (2012), pp. 64-110

Knoppers, Laura (ed.), The Cambridge Companion to Early Modern Women's Writings (Cambridge: Cambridge University Press, 2010), pp. 167-180

Koppitz, Hans-Joachim, 'Zur Verbreitung unterhaltsamer und belehrender deutscher Literatur durch den Buchhandel in der zweiten Hälfte des 16. Jahrhunderts', Jahrbuch für

Internationale Germanistik, 7 (1975), pp. 20-35

Körber, Esther-Beate, 'Deutschsprachige Flugschriften des Dreißigjährigen Krieges 1618 bis 1629', Jahrbuch für Kommunikationsgeschichte, 3 (2001), pp. 1-47

Krontiris, Tina, Oppositional Voices: Women as Writers and Translators of Literature in the English Renaissance (London: Routledge, 1992)

Krontiris, Tina, Oppositional Voices: Women as Writers and Translators in the English Renaissance (London and New York: Routledge, 1992)

Kühlmann, Wilhelm etc. (eds.), Frühe Neuzeit in Deutschland 1520-1620:

Literaturwissenschaftliches Verfasserlexikon, (5 vols., Berlin: de Gruyter, 2011-2016)

Kurras, Lotte, and Machilek, Franz, Caritas Pirckheimer 1467-1532: Eine Ausstellung der katholischen Stadtkirche Nürnberg, Kaiserburg Nürnberg, 26. Juni-8. August 1982 (Munich: Prestel, 1982) 
Lamb, Mary Ellen, 'The Cooke Sisters: Attitudes towards Learned Women in the Renaissance', in Margaret P. Hannay (ed.), Silent but for the Word: Tudor Women as Patrons, Translators and Writers of Religious Works (Kent, OH: Kent State University Press, 1985), pp. 107-125

Lapesa, Rafael, La obra literaria del Marques de Santillana (Madrid: Insula, 1957)

Lecourt, Marcel, 'Une source d'Antoine de la Sale: Simon de Hesdin', Romania, 76 (1955), pp. $39-83$

Lefevere, André, 'Translation Practice(s) and the Circulation of Cultural Capital: Some English Aeneids', in Susan Bassnett and André Lefevere, Constructing Cultures: Essays in Literary Translation (Clevedon: Multilingual Matters, 1998), pp. 41-46

Lefevere, André, Translation, Rewriting and the Manipulation of Literary Fame (London and New York: Routledge, 1992)

Leone de Castris, Pierluigi, 'Kultur und Mäzenatentum am Hof der d'Avalos in Ischia', in Sylvia Ferino-Pagden (ed.), Vittoria Colonna: Dichterin und Muse Michelangelos (Vienna: Skira, 1997), pp. 66-76

Lerer, Seth, 'The Wiles of a Woodcut: Wynkyn de Worde and the Early Tudor Reader', Huntington Library Quarterly 59 (1996), pp. 381-403

Lestringant, Frank, 'The Euhemerist Tradition and the European Perception and Description of the American Indians', in Wolfgang Haase and Meyer Reinhold (eds.), The Classical Tradition and the Americas (2 vols., Berlin: Walter de Gruyter, 1993), I, pp. 173-188

Leu, Urs B. "Nuhu trit herfur o pfaltzischer Lew”: Eine unbekannte Flugschriftensammlung zum Dreißigjährigen Krieg in der Zentralbibliothek Zürich', Gutenberg-Jahrbuch, 84 (2009), pp. 289-306

Levin, Michael J., Agents of Empire: Spanish Ambassadors in Sixteenth-Century Italy (Ithaca NY: Cornell University Press, 2005)

Lezra, Jacques, 'Nationum Origo', in Sandra Bermann and Michael Wood (eds.), Nation, Language, and the Ethics of Translation (Princeton: Princeton University Press, 2005), pp. 203-228

Lines, David A., 'Ethics, Politics and History in Bernardo Segni (1504-1558):

Machiavellianism and Anti-Medicean Sentiment', in Christoph Strosetzki (ed.), Ethik und Politik des Aristoteles in der Frühen Neuzeit (Hamburg: Meiner, 2016), pp. 45-68

Littau, Karin, 'Translation and the materialities of communication', Translation Studies, 9 (2016), pp. 82-96

Looney, Dennis, 'Herodotus and Narrative Art in Renaissance Ferrara: The Translation of Matteo Maria Boiardo', in Priestley, Jessica and Zali, Vasiliki (eds.), Brill's Companion to the Reception of Herodotus in Antiquity and Beyond (Leiden: Brill, 2016), pp. 232-253

Love, Harold, 'Early Modern Print Culture: Assessing the Models', Parergon 20 (2003), pp. 45-64

Luque Alcaide, Elisa, 'Paternidad de Dios en el catecismo zapoteco de Pedro de Feria', in José Luis Illanes, Javier Sesé, Tomás Trigo, Juan Francisco Pozo and José Enériz (eds.), El Dios y Padre de Nuestro Señor Jesucristo (Pamplona: University of Navarra, 2000), pp. 165182 
Mack, Peter, 'Classical Rhetoric in English', in The Oxford History of Classical Reception in English Literature (5 vols., Oxford: Oxford University Press, 2012), II, pp. 75-86

Mack, Peter, 'The Classics in Humanism, Education, and Scholarship', in The Oxford History of Classical Reception in English Literature (5 vols., Oxford: Oxford University Press, 2012), II, pp. 29-55

Mack, Peter, A History of Renaissance Rhetoric 1380-1620 (Oxford: Oxford University Press, 2011)

Mack, Peter, Elizabethan Rhetoric: Theory and Practice (Cambridge: Cambridge University Press, 2002), pp. 11-75

Maffei, Sonia and Settis, Salvatore (eds.), Laocoonte: fama e stile (Rome: Donzelli, 1999)

Maingueneau, Dominique, 'Ethos, scénographie, incorporation', in Amossy, Ruth (ed.), Images de soi dans le discours. La construction de l'ethos, (Lausanne: Delachaux and Niestlé, 1999), pp. 75-100

Maitland, Sarah, What is Cultural Translation? (London, Oxford, and New York: Bloomsbury Publishing, 2017)

Mann, Jenny C., Outlaw Rhetoric: Figuring Vernacular Eloquence in Shakespeare's England (Ithaca: Cornell University Press, 2012)

Marsh, David, The Quattrocento Dialogue: Classical and Humanist Innovation (Cambridge, MA: Harvard University Press, 1981)

Martines, Lauro, Strong Words: Writing and Social Strain in the Italian Renaissance (Baltimore: Johns Hopkins University Press, 2003)

Martínez Sola, María del Carmen, El obispo fray Bernardo de Albuquerque. El marquesado del valle de Oaxaca en el siglo XVI (Oaxaca and Mexico City: Instituto Oaxaqueño de las Culturas, 1998)

Martínez, Joan Bellsolell, 'Miguel Mai y Antonio Sebastiano Minturno en la corte de Carlos V', Studia aurea, 4 (2010), pp. 139-178

Mauss, Marcel, The Gift: The Form and Reason for Exchange in Archaic Societies, trans. W. D. Halls (London: Routledge, 2002)

McCabe, Richard A., 'Ungainefull Arte': Poetry, Patronage, and Print in the Early Modern Era (Oxford: Oxford University Press, 2016)

McKenzie, Donald F., 'The London Book Trade in 1644', in Peter D. McDonald and Michael F. Suarez (eds.), Making Meaning: "Printers of the Mind" and Other Essays (Amherst: University of Massachussets Press, 2002)

McLaughlin, Martin M., Literary Imitation in the Italian Renaissance. The Theory and Practice of Literary Imitation in Italy from Dante to Bembo (Oxford: Clarendon Press, 1995)

McLean, Paul D., The Art of the Network: Strategic Interaction and Patronage in Renaissance Florence (Durham NC: Duke University Press, 2007)

Medica, Massimo and Toniolo, Federica (eds.), Le miniature della Fondazione Cini. Pagine, ritagli, manoscritti, (Milan: Silvana, 2016)

Merisalo, Outi, 'Translating the Classics into the Vernacular in Sixteenth-Century Italy', Renaissance Studies, 29 (2015), pp. 55-77 
Merriel, Juvenal D., To the Image of the Trinity: A Study in the Development of Aquinas' Teaching (Toronto: Pontifical Institute of Medieval Studies, 1990), pp. 132-147

Mildonian, Paul, 'Translation and National Culture in the European Renaissance', in Harald Kittel etc. (eds.), Übersetzung - Translation - Traduction: Ein internationales Handbuch zur Übersetzungsforschung (3 vols., Berlin: de Gruyter, 2004-2011), II, pp. 1397-1410

Montoya, Alicia C., 'Contes du Style des Troubadours: The Memory of the Medieval in Seventeenth-Century French Fairy Tales', in Karl Fugelso and Carol L Robinson (eds.), Medievalism in Technology Old and New (Cambridge: Brewer, 2008), pp. 1-24

Montoya, Alicia C., Medievalist Enlightenment: From Charles Perrault to Jean-Jacques Rousseau (Cambridge: DS Brewer, 2013)

Morini, Massimiliano, Tudor Translation in Theory and Practice (Farnham: Ashgate, 2006)

Mortimer, Ruth, A Portrait of the Author in Sixteenth-Century France (Chapel Hill: Hanes Foundation, 1980)

Müller, Jan-Dirk (ed.), Romane des 15. und 16. Jahrhunderts (Frankfurt: Deutscher Klassiker Verlag, 1990)

Müller, Maria, 'Pontus und Sidonia', in Achim Achnitz (ed.), Deutsches Literatur-Lexikon. Das Mittelalter (8 vols., Berlin and Boston: Walter de Gruyter, 2013), V, pp. 1575-1598

Munari, Simona, 'Translation, Re-Writing and Censorship during the Counter-Reformation', in José María Fernández and Edward Wilson Lee (eds.), Translation and the Book Trade in Early Modern Europe (Cambridge: Cambridge University Press, 2015), pp. 185-200

Nagel, Alexander, 'Gifts for Michelangelo and Vittoria Colonna', The Art Bulletin, 79 (1997), pp. 647-668

Nagel, Alexander, Michelangelo and the Reform of Art (Cambridge, UK: Cambridge University Press, 2000)

Nelson, Jonathan, The Patron's Payoff: Conspicuous Commissions in Italian Renaissance Art (Princeton: Princeton University Press, 2008)

Nesselrath, Arnold, 'I libri di disegni di antichità. Tentativo di una tipologia', in Salvatore Settis (ed.), Memoria dell'antico nell'arte italiana (3 vols., Turin: Einaudi, 1986), III, pp. 87147

Nesvig, Martin, Ideology and Inquisition: The World of the Censors in Early Mexico (New Haven, CT: Yale University Press, 2009)

Norton, Glyn P., The Ideology and Language of Translation in Renaissance France and Their Humanist Antecedents (Genève: Droz, 1984)

O'Bryan, Robin, 'Grotesque Bodies, Princely Delight: Dwarfs in Italian Renaissance Court Imagery', Preternature: Critical and Historical Studies on the Preternatural, 1 (2012), pp. $252-288$

Och, Marjorie, 'Vittoria Colonna and the Commission for a "Mary Magdalene" by Titian', in Reiss, Sheryl E. and David E. Wilkins (eds.), Beyond Isabella: Secular Women Patrons of Art in Renaissance Italy (Kirksville, MO: University of Missouri Press, 2001), pp. 193-223

Oliveira Caetano, Joaquim. 'Francisco de Hollanda (1517-1584): The Fascination of Rome and the Times in Portugal', in Francisco de Hollanda, On Antique Painting, ed. and trans. Alice Sedgwick Wohl (University Park, PA.: Pennsylvania State University Press, 2013), pp. $7-43$ 
Olivier, Eugène, 'Einige neue Mitteilungen über Fabry und seine Familie', trans. Wolfgang Wennig, Hildener Jahrbuch, 6 (1956), pp. 273-286

Olmsted, Wendy, Rhetoric: An Historical Introduction (Malden: Blackwell, 2006)

O'Sullivan, Carol, 'Introduction: Rethinking Methods in Translation History', Translation Studies, 5 (2012), pp. 131-138

Palmer, Nancy, and Melvin Palmer, 'English Editions of French "Contes de Fees" Attributed to Mme D’Aulnoy', Studies in Bibliography, 27 (1974), pp. 227-232

Paoli, Marco, La Dedica. Storia di una strategia editoriale (Italia, secoli XVI-XIX) (Lucca: Maria Pacini Fazzi, 2009)

Pastore, Graziella, 'Petrarca, Boccaccio e l'Italia nella traduzione francese dei Facta et dicta memorabilia di Valerio Massimo', Le Moyen Français, 66 (2010), pp. 87-100

Pender, Patricia and Smith, Rosalind (eds.), Material Cultures of Early Modern Women's Writing (Basingstoke: Palgrave, 2014)

Pender, Patricia, Early Modern Women's Writing and the Rhetoric of Modesty (Basingstoke: Palgrave Macmillan, 2012)

Pereda, Felipe, 'Ántigüedades judías y piedad Cristiana: Francisco de Holanda de los Desenhos de El Escoarial a las Aetatibus Mundi Imagines', Reales Sitios 156 (2003): 2-15

Pérez de Tudela, Almudena, 'Documenti Inediti su Giulio Clovio al Servizio della Famiglia Farnese', Aurea Parma, 84, 2 (2000), pp. 280-307

Pérez Férnandez, José Marìa and Wilson-Lee, Edward (eds.), Translation and the Book Trade in Early Modern Europe (Cambridge: Cambridge University Press, 2014)

Peterson, Richard S., Imitation and Praise in the Poetry of Ben Jonson (Farnham: Ashgate, 2011 [1981])

Pollnitz, Aysha, Princely Education in Early Modern Britain (Cambridge: Cambridge University Press, 2015)

Poole, Stafford, Pedro Moya de Contreras: Catholic Reform and Royal Power in New Spain, 1571-1591 (Berkeley: University of California Press, 1987)

Price Zimmerman, T. C., Paolo Giovio: The Historian and the Crisis of Sixteenth-century Italy (Princeton: Princeton University Press, 1996)

Pym, Anthony, Method in Translation History (London: Routledge, 1998)

Pym, Anthony, 'Shortcomings in the Historiography of Translation', Babel, 28 (1992), pp. 221-235

Ragionieri, Pina (ed.), Vittoria Colonna e Michelangelo, Casa Buonarroti, Florence, 24 May12 September, 2005 (Florence, Mandragora, 2005)

Raynard, Sophie, 'New Poetics versus Old Print: Fairy Tales, Animal Fables, and the Gaulois Past', Marvels \& Tales, 21 (2007), pp. 93-106

Regoliosi, Mariangela, 'Il paratesto dei manoscritti', Paratesto 3 (2004), pp. 9-33

Rener, Frederick M., Interpretatio. Language and Translation from Cicero to Tytler (Amsterdam-Atlanta: Rodopi, 1989)

Rhodes, Dennis E., Silent Printers: Anonymous Printing at Venice in the Sixteenth Century (London: British Library, 1995) 
Rhodes, Neil, 'Status Anxiety and English Renaissance Translation', Helen Smith and Louise Wilson (eds.), Renaissance Paratexts (Cambridge, UK: Cambridge University Press, 2011), pp. 107-120

Richardson, Brian, Manuscript Culture in Renaissance Italy (Cambridge and New York: Cambridge University Press, 2009)

Rizzi, Andrea, Vernacular Translators in Quattrocento Italy: Scribal Culture, Authority, and Agency (Turnout: Brepols, 2017)

Robert, Raymonde, Le conte de fées littéraire en France: De la fin du XVIIe à la fin du XVIIIe siècle, ed. Nadine Jasmin and Claire Debru (Paris: Champion, 2002)

Robert, Raymonde., 'Les conteurs français lecteurs de Basile: Mlle Lhéritier, Mlle de La Force, un auteur anonyme, Cazotte', Romanic Review, 99 (2008), pp. 333-348

Rosenthal, Earl, 'The Diffusion of the Italian Renaissance Style in Western European Art', Sixteenth Century Journal, 9 (1978), pp. 33-45

Ross, Sarah Gwyneth, The Birth of Feminism: Woman as Intellect in Renaissance Italy and England (Cambridge, MA: Harvard University Press, 2009)

Rummel, Erika, 'Ad fontes: German Humanists as Editors and Translators', in Max Reinhart (ed.), Early Modern German Literature 1350-1700 (Rochester, NY: Camden House, 2007), pp. 331-353

Rundle, Christopher, 'Theories and Methodologies of Translation History: The Value of an Interdisciplinary Approach', The Translator, 20 (2014), pp. 2-8

Saenger, Michael, The Commodification of Textual Engagements in the English Renaissance (Aldershot; Burlington VT: Ashgate, 2006)

Saupé, Yvette and Collinet, Jean-Pierre, 'Charles Perrault: 1628-1703', in Sophie Raynard (ed.), The Teller's Tale: Lives of the Classic Fairy Tale Writers (New York: SUNY Press, 2012), pp. 47-59

Scaillièrez, Cécile, 'Un portrait méconnu de François Ier peint par Jean Clouet. Le frontispice des Histoires de Diodore de Sicile au musée Condé de Chantilly', Revue du Louvre, 4 (1996), pp. 47-52

Schildgen, Brenda Deen etc. (eds.), Other Renaissance. A New Approach to World Literature (New York and Houndmills, UK: Palgrave, 2006)

Schlitt, Melinda, 'Painting, Criticism, and Michelangelo's "Last Judgment" in the Age of the Counter Reformation', in Marcia Hall (ed.), Michelangelo's 'Last Judgment' (Cambridge, Cambridge University Press, 2005), pp. 113-148

Schmidt, Georg, 'Das Reich und Europa in deutschsprachigen Flugschriften: Überlegungen zur räsonierenden Öffentlichkeit und politischen Kultur im 17. Jahrhundert', in Klaus Bußmann and Elke Anna Werner (eds.), Europa im 17. Jahrhundert: Ein politischer Mythos und seine Bilder (Stuttgart: Steiner, 2004), pp. 119-148

Schmidt, Georg, Die Fruchtbringer - eine Teutschhertzige Gesellschaft, ed. Klaus Manger (Heidelberg: Winter, 1999), pp. 5-37

Schmidt, Wieland, 'Vom Lesen und Schreiben im späten Mittelalter', in Dietrich Schmidtke and Helga Schüppert (eds.), Festschrift für Ingeborg Schröbler zum 65. Geburtstag (Tübingen: Max Niemeyer, 1973), pp. 309-327 
Schullian, Dorothy M., 'A Revised List of Manuscripts of Valerius Maximus', Miscellanea Augusto Campana. Medioevo e Umanesimo, 45 (1981), pp. 695-728

Schulz, Armin, Erzähltheorie in mediävistischer Perspektive. Studienausgabe (Berlin and Boston: Walter de Gruyter, 2015)

Schurink, Fred, 'Print, Patronage, and Occasion: Translations of Plutarch's "Moralia" in Tudor England', The Yearbook of English Studies, 38 (2008), pp. 86-101

Schwarz, Werner, 'The Theory of Translation in Sixteenth-Century Germany', Modern Language Review, 40 (1945), pp. 289-299

Scott-Warren, Jason, Sir John Harington and the Book as Gift (Oxford: Oxford University Press, 2001)

Seifert, Lewis C. and Stanton, Domna C. (eds.), Enchanted Eloquence: Fairy Tales by Seventeenth-Century French Women Writers (Toronto: Iter Inc., Centre for Reformation and Renaissance Studies, 2010)

Seznec, Jean, The Survival of the Pagan Gods (Princeton: Princeton University Press, 1953)

Sgarbi, Marco, The Italian Mind: Vernacular Logic in Renaissance Italy (1540-1551) (Leiden: Brill, 2014)

Shelburne, Steven, 'The Epistolary Ethos of Formal Satire', Texas Studies in Literature and Language 36 (1994), pp. 135-165

Sherman, William H., Used Books: Marking Readers in Renaissance England (Philadelphia PA: University of Pennyslvania Press, 2008)

Skinner, Quentin, Reason and Rhetoric in the Philosophy of Hobbes (Cambridge: Cambridge University Press, 1996)

Sloane, Thomas, 'Wilson, Thomas', in Hamilton, The Spenser Encyclopedia, p. 728

Smith-Stark, Thomas, 'Algunas isoglosas zapotecas', in Christina Buenrostro etc. (eds.), Memorias del III Coloquio Internacional de Lingüística Mauricio Swadesh (Mexico City: UNAM, INI, 2007), pp. 69-134

Smith-Stark, Thomas, 'La flexión de tiempo, aspecto y modo en el verbo del zapoteco colonial del valle de Oaxaca', in Áurea López Cruz and Michael Swanton (eds.), Memorias del Coloquio Francisco Belmar (Oaxaca: Biblioteca Francisco de Burgoa, 2008), pp. 377419

Smith-Stark, Thomas, 'La ortografía del zapoteco en el 'Vocabulario' de fray Juan de Córdova', in María de los Ángeles Romero Frizzi (ed.), Escritura zapoteca. 2,500 años de historia (Mexico City: CIESAS, INAH, Editorial Porrúa, and CONACULTA, 2003), pp.393448

Smith-Stark, Thomas, 'La trilogía catequística: artes, vocabularios y doctrinas en la Nueva España como instrumentos de una política lingüística de normalización', in Rebeca Barriga Villanueva and Pedro Martín Butragueño (eds.), Historia sociolingüística de México (Mexico City: Colegio de México, 2007), pp. 607-647

Smith-Stark, Thomas, 'Phonological description in New Spain', in Otto Zwartjes and Cristina Altman (eds.), Missionary Linguistics II / Lingüistica Misionera II: Orthography and Phonology (Amsterdam: John Benjamins, 2005), pp. 3-64 
Smith-Stark, Thomas, Bogard, Sergio, and López Cruz, Ausencia, Archivo electrónico del 'Vocabvlario' en lengva çapoteca de Juan de Córdova (electronic file, Word Perfect 8, 7.7 MB, 1993

Smith, Helen and Wilson, Louise, Renaissance Paratexts (Cambridge and New York: Cambridge University Press, 2011

Smith, Helen, "Grossly Material Things": Women and Book Production in Early Modern England (Oxford: Oxford University Press, 2012)

Sparks, Garry and Sachse, Frauke, 'A Sixteenth-Century Priest's Field Notes among the Highland Maya: Proto-Theologia as Vade mecum', in Tavárez, Words and Worlds, n.p.

Spini, Giorgio, 'Bibliografia delle opere di Antonio Brucioli', La Bibliofilia 42 (1940), pp. $129-180$

Stanton, Domna C., 'The Demystification of History and Fiction in Villideau's Annales Galantes', Papers on French Seventeenth-Century Literature, 31 (1987), pp. 1-32

Stedman, Allison, Rococo Fiction in France, 1600-1715: Seditious Frivolity (Lanham, MD: Bucknell University Press, 2013)

Stedman, Allison., 'Charmed Eloquence: Lhéritier's Representation of Female Literary Creativity in Late Seventeenth-Century France', Cahiers du dix-septième, 9, (2005), pp. 107121

Stevenson, Jane, Women Latin Poets: Language, Gender and Authority from Antiquity to the Eighteenth Century. Oxford: Oxford University Press, 2005

Stiaffini, Daniela, Giulio di Alessandro: Un Medici a Pisa (Pisa: ETS, 2015)

Stoichita, Victor I., The Self-Aware Image: An Insight into Early Modern Meta-Painting, trans. Anne-Marie Glasheen (Cambridge University Press: Cambridge and New York, 1997 reprinted Turnhout: Brepols, 2015)

Summers, David, Michelangelo and the Language of Art (Princeton, NJ: Princeton University Press, 1981)

Tavares da Conceiçião, Margarida, 'Translating Vitruvius and Measuring the Sky: on Pedro Nunes and Architecture', Nexus Network Journal, 13 (2011), pp. 205-220

Tavárez, David (ed.), Words and Worlds Turned Around: Indigenous Christianities in Colonial Latin America (Boulder: University of Colorado Press, 2017)

Tavárez, David, 'Nahua Intellectuals, Franciscan Scholars, and the devotio moderna in Colonial Mexico', The Americas 70 (2013), pp. 203-235

Tavárez, David, 'Performing the Zaachila Word: The Dominican Invention of Zapotec Christianity', in Words and Worlds, n.p.

Tavárez, David, 'The Passion According to the Wooden Drum: The Christian Appropriation of a Zapotec Ritual Genre in New Spain', The Americas 62 (2006), pp. 413-444

Tavárez, David, The Invisible War: Indigenous Devotions, Discipline, and Dissent in Colonial Mexico (Stanford, CA: Stanford University Press, 2011)

Taylor, Helena, 'Ancients, Moderns, Gender: Marie-Jeanne L'Héritier's “Le Parnasse Reconnoissant, Ou, Le Triomphe de Madame Des-Houlières"', French Studies, 71 (2017), pp. $15-30$ 
Taylor, William B., Magistrates of the Sacred (Stanford, CA: Stanford University Press, 1996)

Thompson, Lawrence S., 'German Translations of the Classics between 1450 and 1550', Journal of English and Germanic Philology, 42 (1943), pp. 343-363

Tinkler, John F., 'Renaissance Humanism and the Genera Eloquentiae', Rhetorica: A Journal of the History of Rhetoric, 5 (1987): pp. 279-309

Tormo y Monzó, Elías (ed.), Os Desenhos das Antigualhas que vio Francisco d'Ollanda pintor português (Madrid: Ministerio de Asuntos Exteriores, 1940)

Träger, Lotte, 'Das Frauenschrifttum in Deutschland von 1500-1650' (PhD diss., Charles University, Prague, 1943)

Tran-Gervat, Yen-Maï and Weinmann, Frédéric, 'Discours sur la traduction', in Yves Chevrel, Annie Cointre, and Yen-Maï Tran-Gervat (eds.), Histoire des traductions en langue française, XVIIe et XVIIIe siècles: 1610-1815 (Lagrasse: Verdier, 2014), pp. 249-367

Tran-Gervat, Yen-Maï, 'Penser la Traduction', in Yves Chevrel, Annie Cointre, and Yen-Maï Tran-Gervat (eds.), Histoire des traductions en langue française, XVIIe et XVIIIe siècles: 1610-1815 (Lagrasse: Verdier, 2014), pp. 369-432

Trill, Suzanne, 'Sixteenth-Century Women's Writing: Mary Sidney's Psalms and the "Femininity" of Translation', in Suzanne Trill and William Zunder (eds.), Writing and the English Renaissance (New York: Longman, 1996), pp. 140-158

Tylus, Jane and Newman, Karen (eds.), Early Modern Cultures of Translation (Philadelphia: University of Pennsylvania Press, 2015)

Uman, Deborah and Bistué, Belen, 'Translation as Collaborative Authorship: Margaret Tyler's "The Mirrour of Princely Deedes and Knighthood", Comparative Literature Studies, 44 (2007), pp. 298-323

Vasconellos, Joaquim de, Antiguidades da Itália por Francisco de Holanda. Descripção Crítica dos Desenhos do Escurial (Lisbon: Imprensa Nacional, 1896)

Vaughan Lock, Anne, 'Meditation of a Penitent Sinner', in Susan Felch (ed.), The Collected Works of Anne Vaughan Lock (Tempe AZ: Arizona Center for Medieval and Renaissance Studies, 1999), pp. 62-71

Venuti, Lawrence, The Translator's Invisibility. A History of Translation (London: Routledge, 1995/2008)

Verdier, Gabrielle, 'De Ma Mère L'Oye à Mother Goose: La fortune des contes de fées littéraires français en Angleterre', in Contacts culturels et échanges linguistiques au XVIIe siècle en France (Tübingen: Papers on French Seventeenth Century Literature, 1997), pp. $185-202$

Verheyan, Egon, The Palazzo del Te in Mantua: Images of Love and Politics (Baltimore and London: Johns Hopkins University Press, 1977)

Villar, Milagros, Códices Petrarquescos en España (Padua: Antenore, 1995)

Vitruvius, On Architecture, ed. and trans. Frank Granger (2 vols., London and New York: William Heinemann Ltd and G.P. Putnam's Sons, 1939)

von Bloh, Ute, Ausgerenkte Ordnung: Vier Prosaepen aus dem Umkreis der Gräfin Elisabeth von Nassau-Saarbrücken: 'Herzog Herpin', 'Lother und Maller', 'Hugo Scheppel', 'Königin Sibille' (Tübingen: Max Niemeyer, 2002) 
Wang, Yu-Chiao, 'Caxton's Romances and Their Early Tudor Readers', Huntington Library Quarterly, 67 (2004), pp. 173-188

Watanabe-O'Kelly, Helen, 'Women's Writing in the Early Modern Period', in Jo Catling (ed.), A History of Women's Writing in Germany, Austria and Switzerland (Cambridge: Cambridge University Press, 2000), pp. 27-44

Weddige, Hilkert, Die 'Historien vom Amadis auss Franckreich': Dokumentarische Grundlegung zur Entstehung und Rezeption (Wiesbaden: Steiner, 1975)

Wehrli, Max, Literatur im deutschen Mittelalter: Eine poetologische Einführung (Stuttgart: Reclam, 1984)

Weller, Emil, Die falschen und fingierten Druckorte. Repertorium der seit Erfindung der Buchdruckerkunst unter falscher Firma erschienenen Schriften (Leipzig: Falcke \& Rössler, 1858)

Weller, Emil, Index Pseudonymorum: Wörterbuch der Pseudonymen oder Verzeichniss aller Autoren, die sich falscher Namen bedienten (Leipzig: Oehme, 1862)

Whaley, Joachim, Germany and the Holy Roman Empire, (2 vols., Oxford: Oxford University Press, 2012)

White, Micheline, 'Introduction: Women, Religious Communities, Prose Genres and Textual Production', in Micheline White (ed.), English Women, Religion, and Textual Production, 1500-1625 (Aldershot: Ashgate, 2011), pp. 1-13

White, Micheline, 'Renaissance Englishwomen and Religious Translations: The Case of Anne Lock's “'Of the Markes of the Children of God” (1590)', English Literary Renaissance, 23 (1999), pp. 375-400

White, Micheline, 'Women Writers and Religious and Literary Circles in the Elizabethan West Country: Anne Dowriche, Anne Lock Prowse, Anne Lock Moyle, Elizabeth Rous, and Ursula Fulford', Modern Philology, 103 (2005), pp. 187-214

Wiesner-Hanks, Merry, 'Kinder, Kirche, Landeskinder: Women Defend their Publishing in Early Modern Germany', in Robin B. Barnes etc. (eds.), Habent sua fata libelli-Books have their own Destiny: Essays in Honor of Robert V. Schnucker (Kirksville, MI: Thomas Jefferson University Press, 1998), pp. 143-152

Wigham, Frank, 'The Rhetoric of Elizabethan Suitors' Letters', PMLA 96 (1981), pp. 864 882

Wilkinson, Robert J., The Kabbalistic Scholars of the Antwerp Polyglot Bible (Leiden: Brill, 2007)

Williams, Deanne, The French Fetish from Chaucer to Shakespeare (Cambridge: Cambridge University Press, 2005)

Winner, Matthias, 'Zum Nachleben des Laokoon in der Renaissance', Jahrbuch der Berliner Museen, 16 (1974), pp. 83-121

Wolf, Michaela and Fukari, Alexandra (eds.), Constructing a Sociology of Translation (Amsterdam and Philadelphia: John Benjamins, 2007)

Woodall, Joanna, Antonis Mor: Art and Authority (Zwolle: Waanders, 2007)

Woudhuysen, H. R., Sir Philip Sidney and the Circulation of Manuscripts, 1558-1640 (Oxford: Clarendon Press, 1996) 
Wright, Gillian, Producing Women's Poetry, 1600-1730 (Cambridge: Cambridge University Press, 2013)

Wunder, Heide, He is the Sun, She is the Moon: Women in Early Modern Germany, trans.

Thomas Dunlap (Cambridge, Mass, and London: Harvard University Press, 1998)

Wyatt, Michael, The Italian Encounter with Tudor England: A Cultural Politics of Translation (Cambridge: Cambridge University Press, 2005)

Yates, Frances A., John Florio: The Life of an Italian in Shakespeare's England (Cambridge: Cambridge University Press, 1934)

Yates, Julian, Error, Misuse, Failure: Object Lessons from the English Renaissance (Minneapolis and London: University of Minnesota Press, 2003)

Zipes, Jack, 'The Meaning of Fairy Tale within the Evolution of Culture', Marvels \& Tales 25 (2011), pp. 221-243 